\title{
JAPANESE PERFORMING ARTS: AN ANNOTATED BIBLIOGRAPHY
}

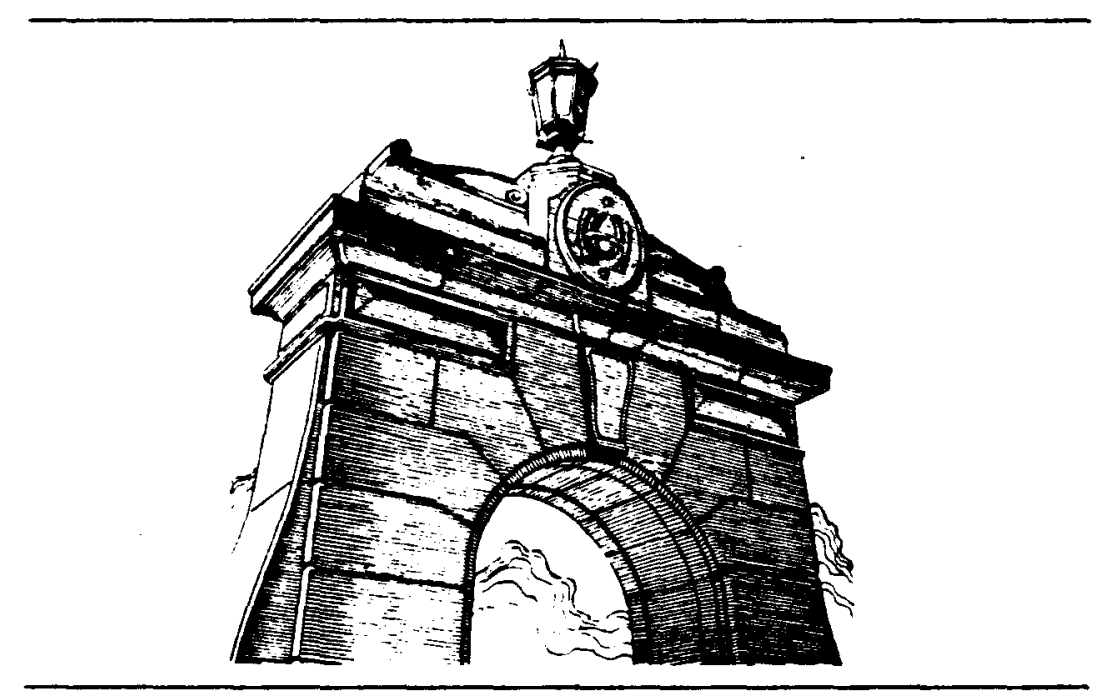

\author{
MASATO MATSLI \\ MINAKO I. SONG \\ TOMOYOSHI RUROKAKA \\ ALBERT IKOMA
}

ASIA COLLECTION

UNIVERSITY OF HAWAII

CENTER FOR ASIAN AND PACIFIC STUDIES

COUNCIL FOR JAPANESE STUDIES

UNIVERSITY OF HAWAII/HONOLULU, HAWAII 
The funds for this compilation came primarily from grants by the Japan-United States Friendship Commission and the University of Hawaii Japan Studies Endowment Committee; additional grants were provided by the University of Hawaii Department of Drama and Theater and the Center for Asian and Pacific Studies.

Copyright $(9) 1981$ by the Center for Asian and Pacific Studies, Council for Japanese Studies, University of Hawaii, Honolulu, Hawaii 96826.

Printed by the Honpo Shoseki Press, Tokyo 


\section{F O R E W O R D}

Publication of this Bibliography represents a significant step forward in the study of Japanese theater and music in America. Few libraries in the United States have more than basic collections of Japanese language materials concerning the vast and colorful field of the performing arts: kabuki, noh, kyōgen, puppet theater, modern drama, music, and dance. And it has always been difficult to determine what holdings might be in any particular library. With this Bibliography now available in English, scholars and students, wherever they may be, will now have access to undoubtedly the largest and most varied collection in the West on Japanese performing arts. It would be futile to pretend that all the works that one might wish were now safely ensconced on shelves in Hawaii for our use, for the literature is vast and acquisition budgets necessarily limited. Fortunately, the Hamilton Library, Japanese Collection, under the direction of Dr. Masato Matsui, is continuing to expand this superb collection year by year and we will look forward to the second edition of this Bibliography in the future. Every serious scholar of the theater, music, or dance of Japan owes the Library staff a debt of gratitude for this extremely useful research tool.

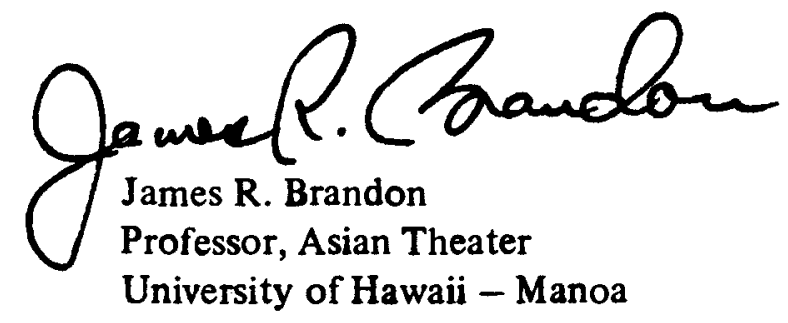




\section{INTRODUCTION}

This bibliography was made possible by grants from the Japan-United States Friendship Commission and the University of Hawaii Japan Studies Endowment Committee. Supplementary support was also received from the University's Department of Drama and Theatre and the Center for Asian and Pacific Studies. The compilers are most grateful.

The present work lists and describes the holdings in the Japanese performing arts of the Thomas Hale Hamilton Library, University of Hawaii at Manoa. The holdings, one of the finest in the country, consists of a wide variety of materials, including drama texts, stage scripts and musical scores, on every form of Japan's performing arts. Thus, it is hoped that this compilation will be of assistance, not only to the student, teacher and researcher but also to the person who aspires to stage actual performances of any of Japan's performing arts. It is also hoped that through this publication, the rich resources of the University of Hawaii in the performing arts can be shared with and enjoyed by a wider circle of interested people living anywhere in the United States.

Annotations are descriptive rather than evaluative. However, entries regarded as having reference value in the staging of performances have been so noted, and certain works, determined by reliable Japanese sources, as having exceptional merit have been so recorded. Japanese references used in this compilation. were Engei hyakka dai jiten (Encyclopedia of Theatre Arts) and Nihon engeki kenkyū shomoku kaidai (Annotated Bibliography of Research Source Materials on Japanese Performing Arts), entries 3 and 8 respectively, in this bibliography. English sources consulted included: James R. Brandon, William P. Malm and Donald H. Shively: Studies in Kabuki: Its Acting, Music, and Historical Context, a Culture Learning Institute monograph, East-West Center (Honolulu: University Press of Hawaii, 1978); Earle Emst, The Kabuki Theatre, an East-West Center Book (Honolulu: University Press of Hawaii, 1974) and Kokusai Bunka Shinkōkai (The Society for International Cultural Relations), KBS Bibliography of Standard Reference Books for Japanese Studies with Descriptive Notes; Vol. VII (B), Theater, Dance and Music (Tokyo: 1960) and Vol. VI-B, Literature, Part II (Tokyo: 1966). 
Bibliographical entries are organized according to the different performing arts and arranged alphabetically by title. The combination of romanized words and newstyle kanji characters conform to present-day common usage in Japan. Each entry has a number to facilitate cross-referencing and indexing. The author and title indexes are arranged alphabetically. Entries and indexes are alphabetized, letter by letter. Japanese surnames are given first, followed by the first name.

Any errors in the work are the sole responsibility of the compilers who will be most grateful to have such errors brought to their attention.

The compilers are indebted to Professor James R. Brandon of the Drama and Theatre Department of the University of Hawaii and the translator of Kabuki: Five Classic Plays (Cambridge: Harvard University, 1975) for his expert advice and enthusiatic support of this project from beginning to end. We wish especially to acknowledge his help in organizing this work, in reviewing the finished product, and in preparing the Foreword. The compilers also wish to thank Professor James T. Araki, chairman of the East Asian Literature Department, Professor Philip N. Jenner of the Department of Indo-Pacific Languages, Professor Minoru Shinoda, chairman of the UH Japan Studies Endowment Committee, Professor John J. Stephan, UH representative to the Japan-United States Friendship Commission, and Professor Stephen Uhalley, director of the Center for Asian and Pacific Studies, for their encouragement and assistance. We also wish to acknowledge Mr. Haruo Suzuki, president of Honpo Shoseki Press, for the printing of this work. Finally, our thanks go to members of the staff of the Asia Collection, particularly Mrs. Aiko Crandall for her calligraphy, Mr. Jun Nakamura for his cataloging of Japanese materials, and Miss Joyce Wright, head of Asia Collection, for her continued support. 


\section{TABLE OF CONTENTS}

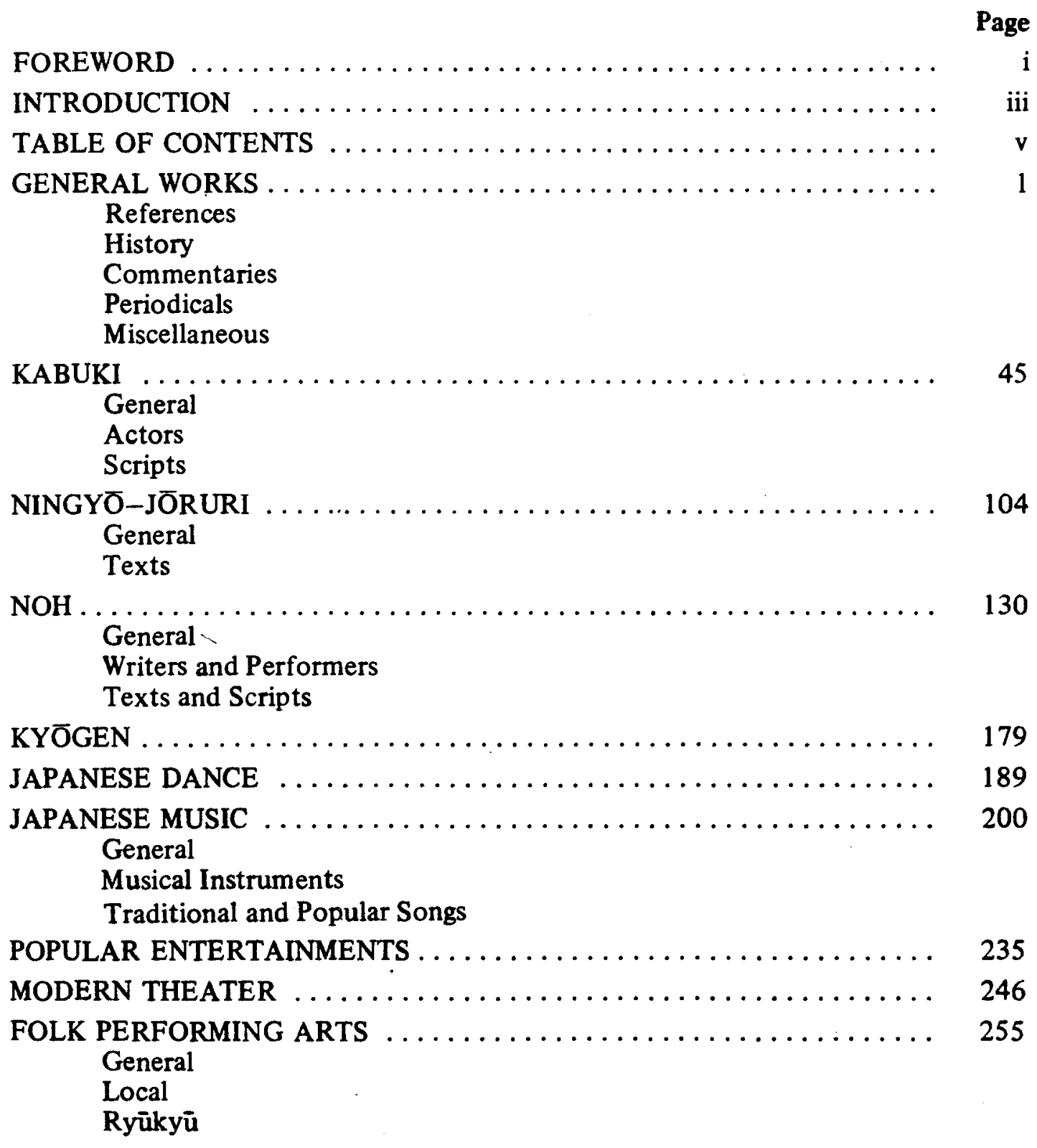

AUTHOR INDEX .............................. 284

TITLE INDEX . . . . . . . . . . . . . . . . . . . . . . . 298 
(Theatrical Arte Collection)

Engek1 Chinaho Kankōka

Tokyo: Gannando Shoten

3 v. 111ua.

\author{
演覀珍書刑行会 \\ 南堂西店 1973.
}

Of the Bdo pariod documents dealing with theatrical arts, those particular ones the etorage and asekeeplng of which were considered difficult to sesure or the publication of which was considered impossible for one reason or another, were reproduced and gethered In this collection of three volumes. Th1s work 1s a reprint of the edition first published In 1915. Of the arte, kabuki is given particular attention and documents include scripts, commentaries, blographical sketches, actors' critical booklets, genealogies, etc. $544 \mathrm{p}$

Of kabuk1, kyōgen (conlc Interlude) and 1örur1 (puppetry) plays, t1t les of plays which are frequently staged or broadcasted or which are difficult to read were complled in this work. Bach page has three horisontel columns, with the top presenting the title in kanil characters with traditional kana readinge, the centar giving the proper pronunciation and accent, and the botto contalning footnotes, particularly on playwrighte, abbrevlated t1tles, alternate titles, performance detalls, etc. Arrangement follows the Japanese syllabic order wth Indexes of abbreviated titles by syllabary and by number of otrokes of ftret tani1 in title. 演劇博物凔编 Tokyo: He 1bonshe 6 v.

$$
\text { 平风社 }
$$

\section{$1960-1961$.}

Asta Raf. PIr625/.E55

Encycloped1e, In eix volumes, contelning approximate 1y 14,000 1tem pertalning to theatrical and performing arte. Covers various Alen and Western countries, with emphasis on Japan. Includes both anclent and modern arta, from ragaku (court wa1c), noh, kabukt, and folk arts to modern theater, movies, rad10, TV, etc. Richly 1llustrated and falrly detalled in annotations with references clted at the end of annotations. Vol. 6 contalne Indexes and appendices, Including a chronologicel lleting of the world' theatrical arte, genealogies of Japanese performing arts, calender of folk porforming arts by prefectures and current noh and kyosen playe. 
Geldō meigen jiten 芸道吕言辞典

(D1ctionary of Pawous Words and Phrases of Performing Arts)

Ed. by Kawatake Sh1getosh1 河竹繁俊編

Tokyo:" Tokyodö 東京堂 1969

276 p.

Asta Raf. PN1583/..12K3

A compilation of words and phrases, with explanations, used in their teachings, art talks and anecdotes by famous personages in the vorld of Japanese classic performing arts. Divided into the following categories: gagaku (court music) and hogaku (Japanese music), noh and kyogen (comic interlude), Jorurl and bunraku (puppet play), kabuk1, and story-telling and performing arts. Appended are blographical and subject Indexes.

Gelnōjlten 芸能辞典

(Dictionary of Performing Arts)

Waseda Dalgaku Engeki Hakubutsukan

Tokyo: Tokyodo

794 P.

早䅛田大学演虡博物館

Ala Ref. PN1582/.J3K3

Provides explanatory comentaries on approximately 1200 items related to both classic and modern porforming arts. Comentarles are rather brief, Intended to present basic knowledge of Interest to the general public, and with emphasis on the current arts. Arranged according to the Japanese syllabary. Appended are genealogies of performers of various performing arts, Including gagaku (court music), noh, puppetry, etc. and listings of titles, playwrights and years of first staging of representative plays in the various arts, including kabuki, malcals, modern plays, etc.

A dictionary of words and phrases used in performing arts from tive early modern period (beginning of Tokugava perlod or around 1600) to present day. Covers rakuge (comic story-telling), kajdan (storytelilng), manzal (comic dlalog), jluta (ballad), ryüköla (popular song), buyo (dance), yose (varlety show), etc. The primary purpose of this work is to differentiate the theatrical terminologies of Ramigeta (Kyoto-0saka) and Bdo (Tokyo). Arranged according to Japunese syllabary and Indexed.

Nhon engek1 j1ten

日本演劇辞典

(D1ctionary of Japanese Theatrical Arts)

Atsuml Seltarō

Tokyo: Sh1n Taishüeha

687 p.
渥美清太郎

新大鱼社 1944 。

Asia Ref. PN2921/.A88 
A compact dictionary contalning approxinately 2800 items, focused on kabukt but Including puppet plays, modern theater, claseic Japanese dances and music, etc. Woh 1s excluded except for items closely related to kabuk1 or dances. Forelgn drame, movies and radio drama are altogether onitted. Arranged according to Japanese syllabary and not indexed.

Nhon engek1 kenkyū shomoku ka1da1

日本演劇研究書目解题 (Annotated Blbllography of Research Source Materials on Japanese Performing Arts) Rawatake Sh1getosh1 Hakage K1ju K1nen Shuppan Kanköka1 河竹 繁俊博士喜寿記念出版刊行会 Tokyo: Hetbonaha 1966 . $353,51,68$ p. As 1a Ref. $23308 / .25 \pi 33$

An annotated blbllography of monographs and collectlons, related to research on Japanese performing arts, published up to December 31 , 1965. Arranged according to Japanese syllabary with title, classification and biographical indexes. Published in commemoration of the $77 \mathrm{th}$ birthday of Professor Sh1getosh1 Kawatake of Waseda University. Contains his blographical sketch and listing of his publications, lectures and rad10 broadcasts. Together with the Bngekt hyakks da1 ilten (Encyclopedia of Theater Arts), this work 1s an ind 1spensable reference for research on Japanese performing arts.

Sengo shinsaku gikyoku fiten

戦後新作虚曲曲事典

(Handbook of Post-War New Dramat1c Plays)

Ok1 Yutaka

Tokyo: Selabō 青蛙房 1960.

263 p. 111us. As1a PL734/.045

A complletion of 87 outetanding plays selected from the 808 new playe staged In Tokyo, Nagoya, Kyoto, Oeake and Kobe after 1945. The playe can be generally divided into two large groups: kabuk1 and modern theater. Kabuk1 Includes Tohö kabuk1 and Roma kabuki. Modern theater Includes ShImpa, ShInkokugeki and Toho Bendaigek1. For each selected play, the eynopese, cast, playwight's comants and interpretations are given. Appended are blographical eketches of playwrighte and an annotated Ilst of the 808 plays. (Compreheosive Bandbook of Japanese Dramat 1c Playe) Bd. by Kavatake Shigetosh1 Tokyo: Hetbonsha 平凡 社 河竹管俊編 634 p. 11148 . As 1a Def. PL734/.1238 
GENERAL WORKS - REPERENCES

A comprehenaive handbook containing 2,500 items pertaining to Japanese dramatic plays. Most of the entries were taken from the Enzek1 hyakka de1-fiten (Encyclopedia of Theater Arte) and revised and new Items on modern theater were added. Essentially, a compact encyclopedia of plays taken from noh, noh kyōgen (comic interlude), kabuki, now kabuk1, modern theater, rad10 drama, IV drama, etc. Arranged according to Japanese syliabary and Irdexed. 
GEIERAL WORKS - HISTORY

1.1
Chūeel getnó bunien shiron (Cultural Bistory of Perforwing Arts of Middle Ages) Ogata Kamekichi Kyoto: San'wa Shobö $548 \mathrm{p}$. 尾形鲁吉

中世芸能丈化史猃

Frow the standpoint of cultural hiatory, atudy of tho origin and traditions of the performing arte of the Middle Ages (around 11801600), Including sarusaku, dengeku, kalraight, ennen, 1marō, shirabyöshi, enkyolu, etc. and how these varioue arts were eventually consolidated into the noh drame. The author is particularly interested in how the cultural values and attitudes of the partod affected the developwents of performing arte. Chūsel gelnō no kenkyü 中世 世荟能 9 研究
(Study of Performing Arts of Mddle Ages) Ara1 Touneyasu 新并恒易 Tokyo: Shin Dokushosha 新誖害杜 1970 986 p. 111 us. As 1a PH2922/.073

A etudy of the performing arts which have been transmitted to the modern times with emphesis on the arts of Incantation, denraku and sarugaku of the Middle Ages (around 1180-1600). Includes discussions of ta-asobi, saimon, etc. Dascribes the traditional arts as they are performad In outlylng erese, particularly the Tokel district of Japan.

Chüeeltek1 geind no tenka1 中世的芸能9展開 (Unfolding the Performing Arte of Midde Agee) Cotö Hajlme Tokyo: Melsendō 明善堂 1959. 292 p. As 1a Fu2921/.669

A tudy of the fundamental characteriotics of noh and aarly labukt of the Mddle Ages (arcund 1180-1600). D1scuseas noh, kgosen, seruselku, densaku, körakemal, etc. as performad in the outlying reglons of Japan. Attempte to datermine the origin of roppo axit used in kabuk1. Branines the origin and spectal effect of the red facial makeup of kabukt performers.

Chüse1 ge1nösh1 kenkyū 中世㐬能史9研究 (Hietorlcal study of Performing Arte of Mddie Ares) Bayash1ye Tetsusaburo Tokyo: Imanand Shoten $556 \mathrm{p}$. 
GEMERAL WORKS - HISTORY

Comprised of three main divieions. At the beglnning is en introductory section presenting the author's assumptions in this otudy, such as on the ignificance of performing arts, wethod of compling a history of performing arts, etc. The first main division is on anclent performing arts and their tranemittal through the ages, taking up the orlgin and special features of ancient erta, ceremonial functions of the arts, Introduction Into Japen and changes of Oriontal performing arts, such as gagaku (court mastc), otc. Tho second main'division discusses the processes by which the performing arts were developed and touches on the various arte, Including dengaku, sarugaku and noh.

The performing arts of the Mddle Ages (around 1180-1600) relled heavily on religion, particularly Buddhism. This work is a sudy of the role and contributions of Shinto shrines and Buddhist temples in the development of performing arts. Divided into two parts, with the first discussing the relationships between shrines and temples and performing arte and the second, shrines and temples and the fine arts:

(H1story of Japanese Theatrical Performances) Haino Shōhe1 Tokyo: Dal1ch1 Shobö 第一書房 1932. 1031 p. As 1a PN2921/. $\mathrm{H27}$

Traces the history of Japanese theater from the origin of performing arts to the development of kebukt during the Genroku period (16881703). Begins with a treatment of the prohistorlc ages, seeking the origine of Japanese dram In Japanese mythology, Shameniem and IIves of the Alnu. Balates the importation of glgaku and busaku from China, developent of sarugaku and dengaku, consolidation of the axts In noh and the beginning and fruition of kabuk1.

Edo J1dal glkyoku shōsetsu toüch1

江户時代虚曲小説通志 (Collection of Dram Texts and Novele of Edo Period) Futagien Shujin Tolsyo: Selshidō 500 p. 繁条園主人

1913. 
GERERAL WORKS - HISTORY

A collection of dran texts, epecifically, törurt texts and theatrical scrlpts, and drawa novels, Including uk1 yo töhl (novelette), sharebon (gay-quarter novelette), nlatōbon (love story), etc. of Bdo perlod (1600-1868). Jöruri texts Include rokusen'ya kassen (The Battles of Coxinga) by Chikamatsu Monzaemon $(1653-1725)$ and nove Is by Thara Salkaku (1642-1693), et al. Includes blographical accounts and 11sts of publications of over 200 playwrights and noveliats of Edo pariod.

Edo jlda1 no geinö 江户時代 9 芸能

(Performing Arts of the Bdo Perlod)

Ikeda Yasaburo 池田顼三底队

Tokyo: Shibundo 至文堂 1960.

220 p.

Ania PK2922/. I38

Describes the origin, charecteristics, etc. of kabuk1, Joruri and popular entertalnonts of the Bdo period. The author atates that the traditional approach to study of perforalng arts is to consider them from staging, dancing, musical and acting'sandpoints but he has an lyzed them fron the viewpolnt of season, thenter sage, actors, epectators and scripte.

Bngek1 gojūnen 演虔五十年

(Rifty Yeare of Dranatic Art)

Tolta Yasuj1 $\vec{P}$ 板 康二

Tokyo: J1f1 Tsūsh1nghe 時事通信社 1950.

308 p.

Aa 1a PN2924/.T583

A history of Japanese theatrical arts during the firat balf of the 20th century wth emphasis on the modern theater. Becords the rise and fall of verlous kabukt troupes, blrth of the Free Theater and Tauk1j1 Iittle Theater, rising popularity of proletarian drama, etc. Includes a chronological table, 1901-1950, of thatrical events, performances and personal1t1es and a list of references.

(P1fty Tears of Drama)

Mijake Shütero

Tokyo: Masu Shobō

403 p.

演劇五十年史

三宅周太郎 繁書房

1953. As 1a PN2924/.M58

Recollects 50 years of the Japanese theatrical world, from the opening of the Rabuktes Theater In 1889 up to 1942. Daletes the

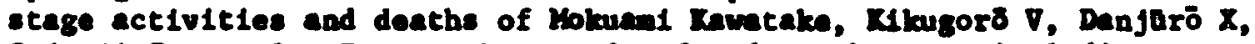
Sadanj1 I, et al. Traces the trends of sodern theater, Includins the establiwhent of the Free Theater, Tsukffl Little Theater, etc. Also covers theatricel activit1es of Kyoto-Osate areas. 
GBIERAL WORKS - HISTORY

21 Engek1oh1 kenkyīi 演虔史研究

(Study of Japanese Thestrical History)

Ed. by Tokyo Te1koku Daigaku Engek1oh1 Gakka1 東京 帝国大学演㓺史学会編

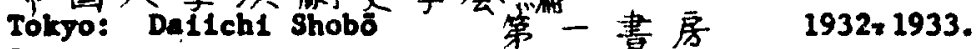

3 v. As 1a PN2924.5/.X3T65

A collection, In three volumes, of essays on nob and krōen (comle Interlude) by theatrical experts aseociated with the Tokyo Univerefty Literature Dopartment. Vol. 1 Includes essays on Mokusal, kabuk1 onnagata (female Impersonator), changes in monomane (initation) in noh drame, yakushe hyobank1 (actors' critical bookleta), etc. Vol. 2 contalns articles on kalralsht (wandering puppetears), vakesho kabuk1 (young mon's kabuk1), Chüghingura (Loyal Forty-Seven Ratainers), etc. Vol. 3 discusees onnagate (feanle inporsonator) roles in noh dram, algnificance of the hanamichi (elevated passageway) in kabult theater, atc.

Galsetsu Whon engeklshi.

Rawatake ShIgetooht

Tokyo: Iwanami Shoten

504 p. 111ua.

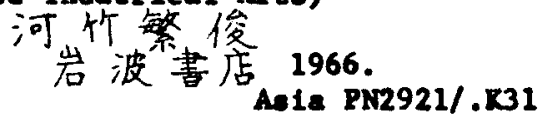

Writien by the author of Hihon engek1 zensht (Comprehansive History of Japanese Theatrical Arts) with the Intent of presenting a loas detalled and more readable version. However, thia lo not a condensed version of the previous work but Includes new materlals although the format resembles the earlier one. He describes the origin and developants of the varioue arts, lacluding bugalou (court music and dance), noh, kabuk1, etc., and tries to note the chenges in the arts within the context of the culturel environment of the tines.

Gainintach1 no gelnōeh1: kavara kojlk1 kara n1ngen kokuhō made 芸人たちの芸能史一河原乞食から人間国宝まで

(Performing Arts History of the Performers: Prom Riverbed Begrers to. LIving hationil Treegures). B1 Rolxusuke 永 六輔 Tokyo: Banchō Shobó 番 町書房 1969. 337 p. A.1a PH1582/.J3834

A series of essays on theatrical ahowe and parsonallties, centered malnly on IV programs up to 1969, by an author who theorizes that performing arts developed out of diserimination against the comoners. For example, kabuk1 actors were f1rst treated as kawara ko $11 k 1$ (riverbed beggars). From his personal expertences and observations, the author makes unusual and Interesting comente on performing arts, pest and present. Appended is a chronological chart noting the rear (1868-1970): significant theatrical and social eventa, popular songs of the year; theatrical parsonalities who ware born or died that year. 
GERBRAL WORKS - HISTORY

Ge1nō kōzōeh1 no kenkyâ 䒧能橎造史9研究

(Study of Historical Coaposition of Perforing Arte)

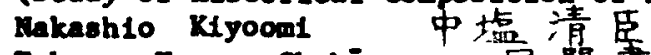

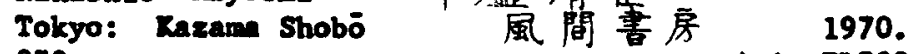

878 p.

As 1a R2708/.N34

An analytical study of the composition of the different parforaing arts, Including noh and kabukl, particularly from a historical atandpolnt of how the origin and past developments affect the changing composition of the arts. The author aseerts that the arts follow a predeternined course of evolution and to understand the art, the geneslogical developents mut be resenrched. The author also polnte out the algnificance of the Interactione between the different performing arts.

Geinōoh1 sōectsu 䒧能史变 説

(Comentarles on Performing Art Higtory)

Iwahasht Royata 崩橋小弥太

Tokyo: Yoshtkewa robunken 1975.

423 p. 11lus.

A compliation of the author' essays on performing arts history rather than a systemetically organised historlcal work. Has detalled coverage of the arte of the Anclent (up to around 1180) and Middle ages (around 1180-1600) but does not touch on the nodern period. Discusses the claselc arts of g1raku, enrugalu, imgro, dengaku, shirabrōaht, etc.

Kabuk1za 歌舞伎座

(Kabuk1ea Thenter)

Dd. by Yoohide Teruj1

吉由暎二編

Tokyo: Rabukdea Shuppambu

332 p. 111 lus.

歌舞徒座出版部 1951 . As ia PR2926/.T6r3

Published on the occasion of the reconstruction and reopening of the Tokyo Rabuk1za Theater in January 1951. Recounts the history of the theater alnce ite establishment in 1889. Includes a chronology of kabukt parformances, both at this theater and othere, between 1888 and 1951 .

Kan' 1 naru Nibon kolugekish 1

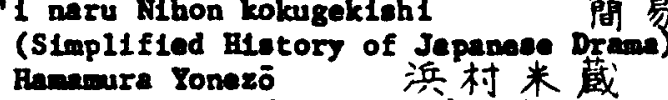
Tokyo: Sh1nchoobs 新潮杜 208 p. 111us.

簡易なる日本国劇史 新潮杜 1926 。 Alla PL734/.H35 
GERERAI WORKS - HISTORY

Comprised of two parta. Part 1 covers the period of clasalc drana and 18 divided into two sections, with the first surveying developments from the primitive age until the fruition of noh and the second; from puppet plays till the Genroku kabuk1 of $1600^{\prime}$. Part 2 discusses the perlod of modern dram and the first section covers the history of drame from late Genroku (late 17 th century) to around 1800 while the second section records the transitions up to the beginaing of Me1j1 perlod (1868).

(H1story of Modern Japanese Drama)

Oyama Is:o 大山 I力

Yamagata: KInda1 Nihon Gikyokush1 Kankōka1 近代'日本虚戈曲刊行会 1969.

$4 \nabla$.

As 1a PL739.6/.09

A historical survey, In four volumes, of modern Japanese drama, opanning a period of over 100 years. Vol. 1 covers the Melj1 perlod (1868-1912) and the birth of modern drama, discussing the contributions of famous writers such as Tsubouch1 Shöyō (1859-1935), Okamoto Rido (1872-1939), Mor1 Öga1 (1862-1922), et al. Vol. 2 surveya the Taleho period (1912-1925) and writers Including Tanizaki Jun'ich1rō (18861964), Kikuchl Kan (1888-1948), Osanal Kaoru (1881-1928), et al. Vo1. 3 discusses pre-World War II Shöwa period (1926-1945) and Vol. 4, the post-World War II Shöwa per1od (1945-present). Bach volume presents an introductory easay on the historical and theatrical background of the period, revlews the highlights and trends of the drama world, and traces the transitions through the works of outstanding writers.

Kinse1 gek1dan sh1: Rabuk1ze-hen 近世劇嗑史・歌舞伎鷹篇 (H1story of Modern Theatrical Horld, Rabukiza Bdition) KImura KInka 木村錦花 Tokyo: Chüō Kōronahn 中央公論社 1936. 789 p. Asia PN2926/.T6R553

Presents the history of kabukt in Rob1k1-cho, Tokyo during the Edo perlod, traces the developments prior to and following the opening of the Kabukiza in 1889 and records the performances at the theater unt11 1934. Notes, 1n detall, plays performed, dates, cast, reviews, etc.

RInse1 Nihon engeklahi 近世日本演劇史 (History of Japanose Thenter In Pre-modern Period) Ihara Tosh1ro 伊原敏郎 Tokyo: Waseda Deigaku Shuppambu 742 p. 111us. 
GERERAI WORTS - HISTORY

An extension of Mthon engek1oht (H1story of Jepanese Thoster) by the aame author. Spans a perlod of about 80 years of the late Bdo period. Divided into three historical perlods: ransel (1789-1800), Bunsel (1818-1829) and Tempo and Kne1 (1831-1853). Gakughe hrobankt (actors' critical booklets) serve as the basic research aterials and the blographles, art stylea, art talkn, etc. of about 100 actors of Edo and Zyoto-Osaka areas are given. Scripte, mulc, theater structure, stage propert1es, government ordinances, etc. are also taken up.

(Notes on Japanese Performing Arts of Recent Times)

kurok1 Kanzō 黑木勘藏

Tokyo: Se1j10ha 青磁社 1943. 444 p.

As 1a PR2922/.1587

A compliation of 15 eseays on the theatrical arte of recent teres, Including etudtes on the special characteristics of kabukt, Canroku period kabukl, different versions of kabukt ecripte, such as on Yanone Gorō (The Arrow Maker), etc. Includes articies on seklyo. earmon, etc.

Comprised of eix chapters. Chap. 1, "Sumary Account of Inpanase Theatrical History," Is the anin section and the remaining five provide further detalls of tten discused in the first chapter. The other chapters are: Chap. 2, "Study of Iōnakeran," Cunp. 3, "Cenroku Period In Kabukl Bistory," Chap. 4, "Miscelleneous Commente on Rabukt," Chep. 5, "Historical Jorur1 of Chtkenateu," and Chap. 6, "Actora' Critical Bookleta."

Kokugek1 yōran 国虔要筧

(Hietortcal Outline of Japanese Drama)

Waseda Delgaku Engek1 Balubutsukan

Tokgo: Arues Shobo 样書居

早稻田大学演㓺线物館 1932.

Al1a PN2921/.T82

A hietorical survey, from the anclent perlod up to the early shön period (mid-1920s), of the performing arts. Divided lato the following ight chapters: claselc and folk parforning arts, noh and brōgen, puppet playe, kebuk1, shlepe and shipgek1 (modern thereter), popular entertainaste, ethoic arte (Brührüs, Kores, Taluan, Alnu, etc.), and wovies. Boferences are cited at the end of the cheptera. Amply illustrated with a general lodex appended. Old publication but st 111 considered useful in research. 
GRIRRAI WORES - HISTORT

34

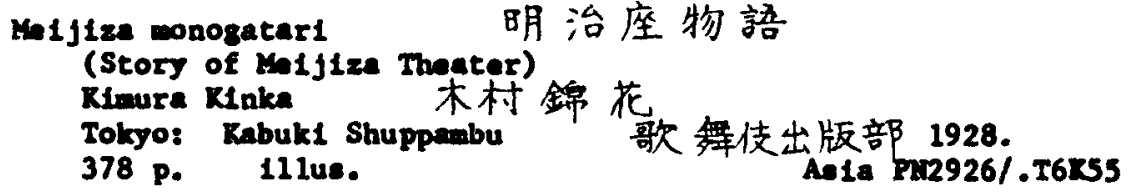

Written and published In March 1928 in comenooration of the construction of the new Helj1es Theater. Ralates the history of W1j1za and in escence, the history of theatrical arte during the Mijl perlod (18681912). Metsumoto Nobuko 松本伸子

Tokyo: Engekt Shuppensha 演劇出版社 1974 . 398 p.

A compliation of theatrical commentaries in newsepers and pertodicale during the first 20 years of kijl pertod (1868-1888). The central theme of the work is annlyais of government polfcies toward the developing Japanese modern theser.

Deplets the establishent and history of the Minamize Theater which 1s the center of kabukt in kyoto. The birthplace of kabukt is the area dosignated as Sh1jo-kawara in Kyoto. This work is a hiotory of kabukt in kyoto up to the early shöwa period. Misonoza shich1jünen bi 御園座七十年史
(70-Year History of Meonoze Theater)

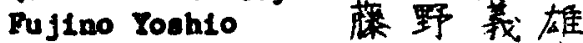
Magoya: Haonoza 御園座 1966. 640 p. 111us. Ala RE2926/.23324575

A detalled chronological record, epanning 70 years between 1895 and 1965, of the Misonoze Theater in Magoya. DLvided into three eections: Malj1, Tatehō and Shöre pertods. Describes the vartous types of theatrical perforances, blographical accounte and eplsodes of performers, changes in the thester' itself, etc. 
A compliation of anecdotes and compentaries on the cultural developmente of the Japanese theater. A number of the articles were previouly published in wonographs and pariodicals. Covers the parforming arte of the ancient pariod, origine of noh, 1ōrurt and kebukt, changes in theatrical arte after World War II, various problem facing the traditional Japanese arte, and International exchange of performing arts in the modern period.

(Course of 100 Years of Japanese Thater)

Tawashima Jumpe 1

Tokgo: Hyōroneha

284 p. 111 us.

门荡順平 評論社 1968 .

Presents the author's Impression and observations of the treads of Japanese theeter efnce the Maffi Beotoration (1868). The author categorises wodern Japanese theater into the following four groups: kabuk1. the traditional Japanese art; ghinpe, Shinkokugek1, Zenehlnsa, etc. which preserve, to some extent, the form and contents of kabuk1; ghingekt which was influenced by Western theater; and talshūgekt wich 18 centered on klgekt or comodies.

Attempta to explain the origin of Japanese draina by exanining the 1fterature, religion, political conditione and cultural environent of the t1mes. Discusses the introduction of arts from abroad and thatr Influences on the native arts. Delves into sarugalu, giralu, densaku, etc., the precursors of nch, and eventual consolidation Into the noh drame.

Consiste of two parts. Fart 1 deals with the period of claselcal theater, etarting with the primitive agea and tracing the developwent of noh. puppet plays and Genroku kabult. Part 2 covers the perlod of odern theater with the enphasis on the full developent of tebuk1. 
GBNRRAL WORTS - HISTORY

42

43

44

\author{
Nihon engekteht 日本演膚史 \\ (H1story of Japanese Theater) \\ Thara Tosh1rō 伊原敏郎 \\ Tokyo: Waseda Dalgaku Shuppambu \\ 762 p. 11lus.
}

早稻田大学出版部 1924 .

Ae1a PM2924.5/.R3J43

A detailed atudy of the or $1 \mathrm{gin}$ and historical developont of kabukt, between the Kelchó per1od (1596-1614) and Hörek1 period (1751-1763). Notes the transitione from onne kabukt (woman's kabuk1) to rakashü kabuk1 (young man's kabuk1) and to garö kabuk1 (men's kabuk1). Traces 200 years of kabukt hlstory by discuselng the blograph1es and performances of famous actors of Edo and Kyoto-0saka. Tha Introductory section provides a brtef account of performing arts from ancient perlod to birth of kabukt.

3

$$
\begin{aligned}
& \text { MLhon engekish1 日本演㓺史 } \\
& \text { (History of Japanese Perfogming Arts) } \\
& \text { Iura Yoshlnobu 林浦芳信 } \\
& \text { Tokyo: Sh1bundō 至文堂 } 1963 . \\
& 156 \text { p. 111ue. As1a PN2921/.I66 }
\end{aligned}
$$

A hietory of Japanese performing arts with emphasis on arts of the ancient and Middle Agea. Rather than a breakdown by historlcal perlode, arrangewent of this work 18 by the history of Individual arts, Including gtgaku, bugaku (court mastc and dance), kagura (Shinto malc and dance), different typas of noh, etc. Includes discussions of modern pertod theatrical arts such as puppet playe, kabuk1, etc. Appended to this lengthy work is a falriy detelled subject Index.

\author{
Mhon engektebt旦本演豦史 \\ (History of Jepenese Theatricel Arts) \\ Takano Tatsuyuk1 高野辰之 \\ Tokyo: Tokjodó 東高堂 1947-1948. \\ 2 v. (v.1-2) As1a PN2921/.T343
}

A collection in three volumes of the lectures by the author, a professor at Tokyo Untversity, given between 1926 and 1936 on the history of Japanese dram. Vol. I covere the porlod from prahtetoric time up to 1600, touching on gleaku, buraku (court muelc and dence), earurelu, ennen and dengaku, which are the precursors of noh, and then discuseing, In deta11, tho development of noh and kyogen (contc Interlude). Vol. 2 to devoted to kabukt. 1ts origin and developient during the 17 th century, Including olunt kabukt, onne kabuk1 (romon's kabuk1), waknehü kabukt (young nen's kabuk1), yero kabuk1 (ma's kabukt) and Ganrolu kabukt. 
GETRRAL WORKS - BISTORY

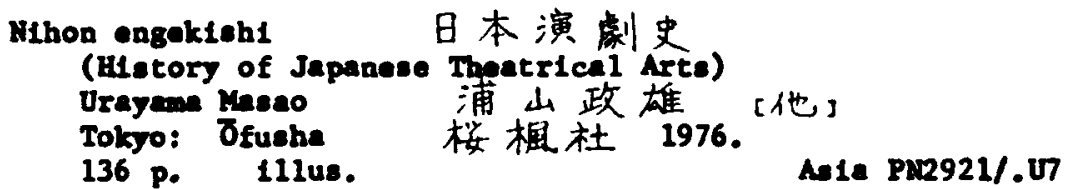

A general chronological survey of Japanese theatrical arte by historical perlode, beginning with the ancient agea (up to Baian paried or around 1180.), Midle Ages (Kamnlara-Vuromeht pertods, around 1180-1600), early modern age (Tokugawa per1od, 1600-1868) and modern per10d (1868present). This work can be considered an introductory treatise on the theatrical arts rather than an in-depth atudy and considers the overall Influances of literature, songs, mustc and dances on the developwent of the performing arte.

(Ireatlees on History of Japanese Theatrical Arte)

Rure Fumiakt

Tokso: Tohtkaku

$$
\text { 点文炳 }
$$

1921.

$128 \mathrm{pe}$ ( $(v, 1)$

Asta PW2921/.887

Iraces the history, evolution and characteristica of the theatrical arts. Vol. I covere the pariod from the introduction of kelratshl (wandering puppeteers) unt11 the developwont of noh and byoren (contc Interlude) of the Muronecht perlod (1392-1573).

Mthon engektsht ronso

日本演㓺史猃丵

(Collection of Basays on Hietory of Japanese Thester) Tokgyo Tetkolau Datgaka Bngekteht Tankyulent 大学演㓺史研究会
Tolsyo: Togetshe
巧芸杜
1937.
607 p.
Ale Pr2921/.T65

A collection of 30 essays by different experte on theatrical arts from ancient to modern pariods. Written on the occaston of the retirement of Professor Tatsuyuk1 Takano from Tokyo Unfversity. Beseys discuse the various parforming arts Including buraku, dengeku, noh, krören, kabuk1, Lörur1, etc.

Mibon engek1 zonuhl 日本演劇全史

(Comprobonstve Hisery of Japanee thetrical Arte)

Ravatake Shigetooht

Tokso: Imenamel Shoten

$1331 \mathrm{p}$.

$$
\begin{aligned}
& \text { 河竹繁俊 } \\
& \text { 岩波書店 } 1959 \text { 。 } \\
& \text { Ala PN2921/.K3 }
\end{aligned}
$$

A detalled study of the dovelopment of performing arte in Japan. The Initial article polats out that the introduction of giralsu to Japan wes the etarting point. There are 12 chepters and an appandix with chronological listing of perforting arte from the 
mythological age to the present. The ancient period (up to around 1180) 1s covered In Chap. 1 wth emphesis on bugaku (court music and dance). The Middle Ages (around 1180-1600) are covered in Chap. 2 wth enphasis on noh. The early modern period (1600-1868) 1s covered in Chapters 3-7 with the focus on developaent of kabuk1. The remining chapters covere the modern period (1868-present) and deal wth new kabuk1. and modern theater.

Tokyo: Alaht Shlmbunkhe 1956.

1 v. Lllus. Als Ref. PN2921/.128

An 11 lustrated record of Japanese theater with 400 plates of photographs and reproductions of colored woodblock prints, delineating the history of performing axts from the primltive age of the dance of coddese Amo-no-usume in front of the cave in which Sun Goddess Amaterasu was hidden to the development of modern theater. Narrative explanations of theatrical history are 1ncduded. Attached 1s an Engliah text titled, "A Brief Survey of the Development of Japanese Theater Arts."

50 Nihon geinó no ganryo: sangaku kō (Soure 日本芸能 9源流: 散涾考 Arts: Coneideration of Sangaku)

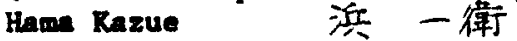
Tokyo: Kedokawa Shoten 角川妻店 1968 。 442 p. 111us. Asta PN2920/.H35

An analytical probe into the source of performing arts with the focue on the origin end developast of sangaku. The author pointe out the popular art of the period, eangeku, ovolved as the counterpart of the court mulc, gagaku. The work descrtbes the introduction of glgaku from China and development of sarugaku, dengaku and ennen, precuraors of noh and the modern performing arta.

Bxanfines Japanese mythologies, establishment and transmittal of anclent performing arts and relationahipe between folkloric religion and performing arts. The author's incent is to determine the nature and characteristice of the Japanese paople of the anclent ages by analyzing the cultural history of the performing arte. 
GERBRAT WORKS - HISTORY

M1hon gelnosh1: Choset kabu no kenkju 日本䒧能史一中世歌舞の研究 (History of Japanese Parforming Artes Study of songe and Dances of Mddle Agea)

Iwahash1 royata

Tolsyo: Catensha

214 p.

岩栭少弥太

Study of the songe and dences of the Mddle Ages (around 1180-1600) from a literary standpolnt. Begins with an examination of karura (Shinto mustc and dance), dengeku, etc. Proceeds to discussions of roel, kuecan1, Imayd, sh1rabydoh1, etc. which flourtshed during the Middle Ages. study is based on literature pertaining to the arte of the period.

Nihon getnōsh1 köwa

日本䒧能史諎話 (Lectures on HLtory of Japanase Performing Arts) Kontye Toyotakn 小宮曹隆 Tokyo: Murasaki no Xokyōsha 186 p.

$$
\begin{aligned}
& \text { 紫乃故郎舍 } 1949 \text { 。 } \\
& \text { Alia P212921/.1.65 }
\end{aligned}
$$

A compliation of 11 lectures of the hietory of Japanese performing erte given in July 1948 as the eumer lecture serles of Tokyo Women's Untverelty. Talke Include relationshlp of calligraphy, flower arrangement, tea coremony, etc. to performing arts. Lectures were given by experte in their respective flelds, tacluding Konj1 Shuzul's talk on the appreciation of puppet plays and knbukt. (Study of history of Japanese Performing Arte) Yatsuda Osamu 松由修 Tokyo: Hbsel Datgaku Shuppanikyolu 289 p.

$$
\begin{aligned}
& \text { 法政大学出版局 } 1974 \text {. } \\
& \text { Alla PH2922/.MB8 }
\end{aligned}
$$

A compllation of eseays, previously publiabed in periodicals and monographs, expounding the author's theory that the underlying currente of Japanese performing arte history are "discrinination" and "derla1on" and that the arte had to overcome then to aurvive. Because of diacrinination, beauty was born and out of darimeses, light energed. Thlo paradoxicel eltuation to the fundematel characterietic of Japanase parforming arts.

55 Nihon gektjōsht

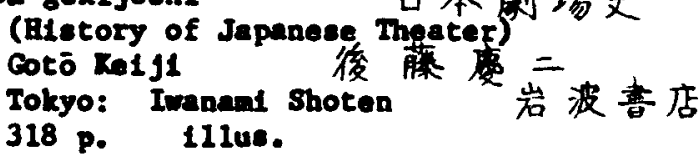

1925. AsLa PN2921/.G68 
GESBRAT WORTS - HISTORY

The author. who ts an archltect, describes the history of Japanese theater from an architectural standpoint. Includes a rather lengthy, 11lustrated appendix on structure of theaters in Europe. Also conteins a brief chronological table, 1624-1864, of highlighte of theater construction in Japan.

$A$ descriptive history of Japanese theater architecture from Ancient Agee to the beginning of the Modern Age (1868). Divided Into historical pariods: Kantyo, Yameto, Rera, Heian, Kanakura, Muromech1, Momoyan, and Edo. Discusses theatrical performances and theater architecture of each pariod. Includes detalled sketches of theater layout. There are two lengthy appendices: a chronological table, 1596-1911, of theater structure including stage, seating arrangements, green room, etc., and for comparative purposes, a history of Chinese theater architecture.

(IIIustrated History of Japanese Theeter)

Takeucht Yoshttarō

Tokyo: Mbu Sholn

$$
\text { 竹内芳太郎 }
$$

王生書院 1935.

2 v. 11lus.

Comprised of two volumes and each volume begine with photos and sketches of Japanese theetere followed by a textual section. Vol. 1 contalns an abbreviated history of theatrical performances, Including cowments on noh, dengaku, sarugaku, etc., and a record of the histortcal development of theater etages. Vol. 2 Includes an article on the origin and developient of kabukt and an account of etructural otyle of theaters.

日本虔曲史

$$
\text { 河竹繁俊 }
$$

桜相社 1964 。

Asta $\mathrm{PL734/.138}$

A comprehenelve history of the origine of performing arts, such as gleaku, bugalu, saruraku, etc., In the anctent period. The second part 1s lengthy, consisting of alght chapters on the changes and developmente in Japenese dran from the Middle Ages (around 11801600) up to the modern pariod. The latter eection covers noh, puppet plays, lesbuk1, modern theater, etc. 
ERRERAL WORES - HISTORY

Mihon shoatn bunka shiryō shüse1, da1 12-15-kan: getno kiroku

日本点民丈化史料集成，第十二一十五卷：芸能記唋

(Collection of Mnterials on Japanese Popular Culture, Vols. 12-15: Racords of Performing Arts) Ge1nooh1 Renkyoka1

Tokyo: San'teht Shobs

芸能史研究会

4 v.

三一青房 1975 .

Asta Pi2920/.185/v.12-15

Vol. 12 contalns two parts. Part 1 ts the Matoudalre Yacato-no-Kant nikkl (Diary of Lord Matsudelra Yamato) which ts the maln document In this volume. Also containe liara-cho koxy kiroku (Bocords of Theatrical Performances of Nara) and the folloulns kabukt records: Bakamurese Tampo nikk1 (Diary of Maknemuraza Thoater during Tenpo Pertod, 1830-1844) and Makenuraze nikkiehs (D1gest of Diary of

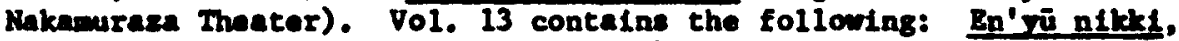
a diary recording 13 yeare (1773-1785) of post-ratiremant da11y I1fe

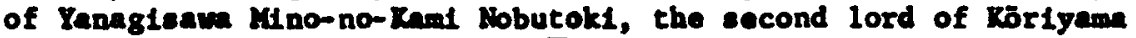

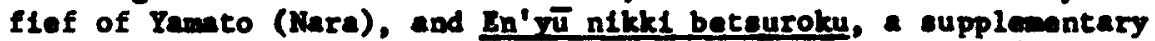
diary recording the viewing by llobutoki of the Edo sanza (Naknurasa, Ichimuraza and Horttaza Theaters) and Jörur1sa Theater. Vol. 14 contafns sete nos. 1-21 of Byote kyakuhhoku iō, wich constets of 42 sets of kabule mater1e 1s, inly benzuke (actors' ratinge), and aloo yakush hrobank1 (actors' critical booklet), kabukt prograns, portralts of famous performers, etc. The anteriale are mostly on kabuk1 in Oaakn and this work is the nost complete of Its kind and conisidered indispensablo in research on Osaka kabukt. Vol. 14 covere the period, 1624-1811. Pol. 15 contelns sete nos. 22-36 and atx appendices coverting the period, 1812-1827.

王朝演虔史

(B1story of Performing Arts durins the Dyneste Peride)

Ogata Rambich1

Tokjo: Meljt Shoin

360 p.

尾形毫吉

明治書院 1948.

Asta PR2922/.034

Dascribes the batc features and historical significance of the cownoners' performing arte durlag the dynastle or Halan-chö (7941192). Divided Into two parta: welcal drama, and songe and dances. Sarusalou, katrateht (wanderlng puppeteer), denralu and ennen are discuseed In the first part and imso and shirabrōaht in the second part.

Tokyo: Bthon Bōeō Ryoteat

206 p. I1lus.
日本放送協会 1978 。 A1a P12921/.W49 
The author belleves that Japanese perfornting arte were born and nurtured in an enviroment of fraternisation between the local populace and ttinerant parformars who ut1lised outdoor epaces or Indoor roons as thalr etages. This work traces the footstepe of the visorous traveling performors, who roand the countryside of Japan, uelng any avallable open opace to atage their ects. (Illustrated History of Wodern Thastrical Arta) Bd. by Mibon Kindalah1 renkyuika1 日本近代史研究会编 Tokyo: Sōgencha 创元社 2954. $1 \nabla . \quad$ LIus. As 1a PN2924/.N54

A photo album, wth explenatory comantar1es, on Japanese theatrical arts, covering the period from 1868 to 1953. Begine wth a photo and coments on Edo kebulet of 1868. Proceeds to the modern theater of. Talaho perlod (1912-1926), such as the Free Theser, Teuklf1 Little Theater, now kabukt, etc. Covere tho lntroduction of sound novies, the patrlotic songe during World War II, transition to pacetim songs of post-World War II and development of national parforming arte during the 1950s. Includes a chronological table of the hIghlights of modern theater betwen 1868 and 1953.

(Shöchtlu's Blotory of 70 Years)

Shochtlas Kabusblkt Katsha

Tokjo: 1964.

970 p. 111us.

\author{
松竹株式会社
}

Ania Pu1999/.S5S5

Relates the establiahnont in 1902 of the general partnerahip company of Shochlla by the brothere, Shiral Matsujtro and Jtant Takejtrö. Traces the historical developant of Shöchika Co., Ltd. unt11 1963. The book is made up of three parts: present status of company. Shöchika hiatory, and company record and documentary materials.

Tōto Me1f1 engek1sh1 (Bistory of Tokyo Thestrical Arts of Malj1 Parlod) Aktba Tarō 秋庭太郎

Tolsyo: Ōtor1 Shuppan 国出版 632 p. 11lus.

1975. Asta PIR926/.T6N4

Traces the transitions of the theatrical world, with Tokyo as the center, over a span of 45 yoars. Begine with the shibal (thatetical playe) of the Edo Saruwakn-cho Sanze (Bakararaza, IchLmaraza and Moritexa Thasters) of the late Edo pertod, through the kabukt, modern theater, etc. of Ma1j1 per1od (1868-1912), and up to the ctart of Talshō pariod (1912 and 1913). 
GBIERAL HORTS - HISTORY

65

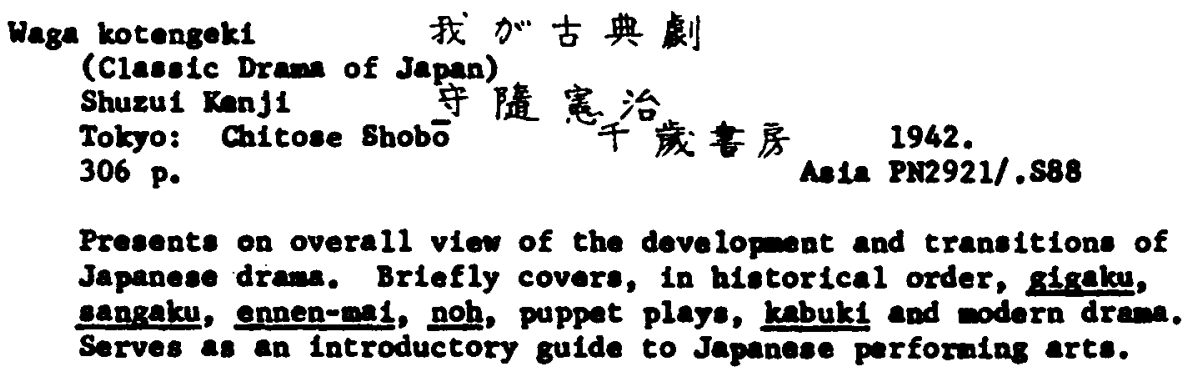

Zoku chūsel geinō no kenkȳi: dengalas o chūohln to ohlte 続中世 䒧能 9研究一四㷛を中心として

(Supplemental study of Performing Arts of Mdddle Ages: Centered on Densaku)

Arat Truneyasu

Tokyo: Shin Dolkushosha 1974.

898 p. 111us. Ala R,2922/.A731

A supplewantal work to the author's Chüsel selnō no kenkrū (Study of Perforning Arts of Mddle Ages). This etudy 10 centered on dengaku which appeared on the Japanese ecene in the late 10ch century and was prominently performed for three centur1es. Bven in this 20th century, dengaku 18 still being parformod in 70 places throughout Japen and 18 reported in this work in relation to festivale. This ctudy also contalne a general history of dengaku. 
GERERAL WORKS - COMERNTARIES

Dento engek1 no hased

伝絖演劇の発想

(OrIginal Concepte In Traditional Theatrical Arts)

Takechi Tetsuj1

Tokgo: Haga Shoten

武智全失二

342 p. Illus.

芳賀妻店 1967 .

Al1a Pu2924.5/. K3T34

Consiste of three main sections. The first is an abbreviated hietorical account of the birth and development of kabuki. The second section discusses the present status of traditional theatrical arts, with emphasis on kabuk1. The third section reves ls krōgen (contc interlude) as a traditional art and concludes with the birth of nodern, avent-garde theater. A rambling account of theatrical arts with the focus on kabuk1.

(Trivial Talke on Traditional Theatrical Arts) Takita Te1j1 滝田真治

Tokyo: Shomotsu Tembösha 音物展望社 1943.

308 p. $111 u$.

An 1a PN2924.5/.R3T35

Comments on the origin of kabuki, Influence of Jorurt (puppet play) on kabuki, development of kabukl krōgen (comfe Interlude), and Influence of kabukt on shimpe and Shingekl. Takes up the plays of Chikamatsu Monzaenon (1653-1725) and Tauruya Namboku (1755-1829). The concluding section contalne afscellaneous talks on modern theater, Including Osanal Kaoru's plays and status of theatrical arts in Iafwan where the author wae a professor.

(P1ve Hundred Questlons and Anewers on Theatrical Arts) Kanako Ban'u 兼子伴舟 Tokyo: Irohe Shobō いろは書房 1914. $195 \mathrm{p}$.

A collection of questions and answers pertaining to kabukt and other theatricel arts which were published in the "Theater Question and Answers" column of the perlodical, Engek1 gaho (Theatrical Arte P(ctoriel). Beflects the interast, tastes and outlook of the populace, regarding the theater, at the tion.

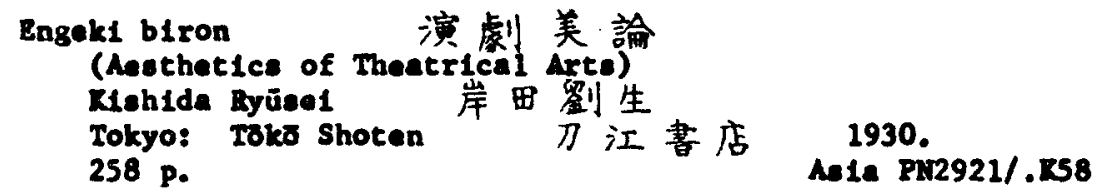


GEMERAL HORKS - COMERTARIES

The author who is a Hestern oll painting artist cherishes the old theater, nawe 1y, kebuk1 and lderürek1 (puppetry), and thecrices on their beauty and aesthotic appeal. Firet, the describes the characteristice that ake up the old thastical arts, analyses the different Ingrediente, such a actors, hanamichl (elevated paseagowny), etc., and reveals his asthatic approciation of them from an artist's viewpoint. Included is a reproduction of the author's oll painting of actors parforaing on the banamichi.

71

$$
\begin{aligned}
& \begin{array}{l}
\text { Engek1 dang1 演㓺談 義 } \\
\text { (DLscourse on Performing Arts) }
\end{array} \\
& \text { Thare Seiselen (Tochlrō) } \\
& \text { Tokyo: Okakura Shobō } \\
& 242 \text { p. } \\
& \text { 伊原青々園【敏郎] } \\
& \text { 肉食書房 } 1934 \text {. } \\
& \text { As 1e P22921/. } 143
\end{aligned}
$$

A selected compliation of eseaye and articles, concernitig the performing arta, published by the author In nowspapers and magazines between 1927 and 1931. The author 1s a drane critic and begins the book with articles on the function of a drana critlc and his youthful days as a critic for the newpapers. Included are such diverse articles as biographies of actors, paintinge by kabuki performers, appreciation of Chühingure (The Loyal Forty-seven Datainers), etc. (Fundamental Problean in the Study of Drama) Obata Notoo 小草元雄 Tokyo: Razama Shobō 栭妻房 1969. 534 p. 111ue. Ale PA1655/.023

The author states thet the study of drane orlglonted in early 20th century In Gernany with Mrchermann as 1 te firet advocate, and that the concept is still new in Japen. Th1s work to a survey of the problems involved and is composed of four parte. Part 1 defines the concept and paramater of dram study. Rarts 2 and 3 probe into the detalis of the fundametel problese affecting the etudy. Part 4 takes up claselc Japanese theatrical arte, malaly brören and kabuk1. and considers the characterietice, performars, etege, etc. of these arto. 
Obiza, Borlkawa, and the performere. Chap. 2 "Translated Plays and Personalities in the pleys," discusees Japanese vereione of "Salom," "Paust." "Othe110;" etc. Chap. 3 to a alecellansous section witl comente on traditional and wodern Jepanese theaters, famous actors, playur 1ghte, etc.

(P1igrimage of Theatrical Performaces) Mrake Shütarō 三宅 周太郎 Tokgo: Chīō Koronohn 中央公論社 1935. 1 v. An1a R22921/.M586

Contalna mainly comentaries, concerning kebukd playe and actors, witten by the author between 1928 and 1935. Includes other item, such as consente on puppet playe and other theatrical parformances, extracte from nowper theater raviews, recollectlons of deceased actore and pleyrelghte, etc. There is seque1, Zoku engekt funrel (P1lgrimge to Theatrical Performances, Supplement), covering the subsequent years, 1935 to 1940.

(liow Trends In Drama) Oeenai Reorv Tokyo: Belabunkan $384 \mathrm{p}$.

演㓺新潮

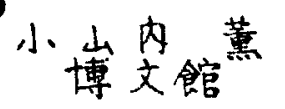

1908. As 1a PIR2924/.083

A collection of articles by the author published in the periodical, Kabukt, betwen 1904 and 1907. The firet half of the book introducas Buropean theater, including Tbeen'e playe. The latter half consiets of coments on kabuk1 playe Including Yoohitsune ecmbonzalare (The Thousand Cherry Tress of Yoshltauna), Sukeroku, tc.

(Theatrical Arte and Itterature)

Oaanal Knory 1. 山 内 Tokyo: Se1jō Gakuen Köenka1 523 p. 11lus.

葷. 成城学围後援会 1926 。 Ala Pino39/.083

Attenpts to show the relationohlps between theatrical arts and 11terature. Of the 13 chapters in the book, flve are based on viewe expreased by Amarican and European echolars on theater and 11terature. Other articles discuse contact polnts between literature and theater, analyais of dranatic playe, study of kabuk1, theater and soclety, etc.

(Theatrical Miscellang) Bōjō midej1 北條秀司 Tokyo: Youlur1 Shimbunsha 1975. 336 p. 
The author, a playwight for over 40 years, complles into this work brief articles on the theeter which had been published in newepapers, perlodicals, etc. Ble wrk Includes cownes on nodern thester and trends, hle pereonal iffe and famlly, tributes to ble decensed collengues wo were ectors and playrights, etc.

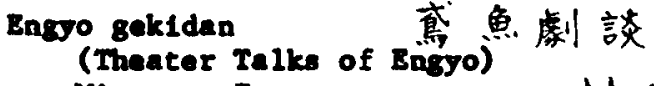

$$
\begin{aligned}
& \text { Mtamura Engyo 三田村嶌魚 }
\end{aligned}
$$

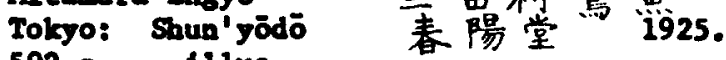

$$
\begin{aligned}
& 502 \text { p. Hlue. As1a PL767/.MS8 }
\end{aligned}
$$

The author, who has interest in sociological research of the Edo perlod, seeke bistorical evidences of the events, custons and social conditions portrayed in theatrical playe. Bramples of rabukt playe acrutinised are Chühingura (Loyal Forty-seven Rotainera), Sannin KIchiza (The Three Kichiza), etc.

Geldan no kankyũ: sh1n'1 denohokō

芸談の研究一心意伀承考

(Study of Art Talke: Thoughte on Spiritual Transmiesion)

Uehara Teruo 上原蛘男

Tokyo: Waseda Dalgaku Shuppambu

277 p. $111 \mathrm{us}$.

早稻田大学出版部 1972 . As1a PA1707/.124

A syatematic study of art talke, particularly frow a folkloristc vieupolnt. Bather than the contente of art talks, focuses on the atudy of the environent, which encouraged expreselon on art, and on the attitudes, forms, etc. of art talks.

Co1gō gojünon 苔菜五十年

(P1fty Yare of Theatrical Work)

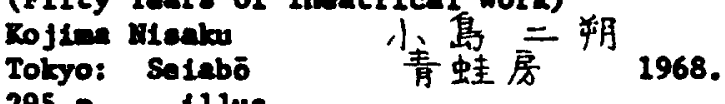

295 P. 11lue. Ale P12927/.1563

A coupliation of the author's eseays on his 50 yeare of theatrical career, firot a a playuright of byöen (cleselcal comedy) thon as a playwright of theatrical and dance playe. The author was a diaciple of the great playwright, rawatake Molvuni (1816-1893), and begins h1s easaye with recollection of his tratalng under Holvunt. The author presents his porsonal observations of kabuk1. krojeen and other theatrical porformances and performars, parsonel experiences and anecdotes, to provide a readable narrative.

Ikeda Tasaburō

Tokyo: Ireselkt Shoten

245 p.

$$
\begin{aligned}
& \text { 池田弥三郎 } \\
& \text { 岩崎書店 } 1955 . \\
& \text { Ala GR340/.M575/v.1 }
\end{aligned}
$$


GEMERAL WORKS - COMEENTARIES

The tarting point of performing arts is religlous and ritualistc actions and movenente. Therefore, its early history to not recorded In any document and they vere tranealtted as part of the folk arte. On this assumption, the author introduces the varlous arts, Including kabuki, noh, Japanese dance, folk performing arte, Ryukyuan dance, etc., and examlnes each from hletorical and folkloristlc standpolnte.

Toki Michiko 土岐迪子

Tokyo: Rajima Kenkyūjo Shuppanka1

242 p. 111ua.

鹿岛研究所出版会 1970 . As1a Pr2927/.T67

Portrays the personal and profesatonal 11ves, notable-performances and Individuailetic contributions to theater of Japanese women in performing arts. Categorized into three groups: theater and wovies, Japanese dance and Japanese mulc. Performers deplcted Include Mnteul Sumako of Shingekl and Mizutani Yaeko of ShImpa, Azume Tokuho and Hanayag1 Suml of Japanese dencing and Enju Dago of Japanese mustc.

Gel no kao: dentō to zen'el

(The Face of Art: Tradition and Avant-garde)

芸 9 新 - 伝統と前衛

Mehilyam Mateunosuke 西山松之助

Tokjo: Shüicha 秀英社 1969.

325 p. 11lus. Asia PU1582/.J3N55

A collection of over 50 short articles by the author on theatrical arte. Articles had been previously published in varioue periodicals and newepapers. Touches on zeand's noh concepts, Ichiluave Danjurd, traditions of kabukl, ballet, modern theater, etc. Attempte to present the different facete of Japanese theatrical arte, past and present. (About Skilis and Arts)

Romiya Toyotaka

Tokyo: Kadokawa Shoten

350 p.

$$
\text { 芸のこと，芸術のこと }
$$

小宫 曹隆

A comptlation of eseaye by the author on performing arte, ranging from gagaku (court music) to modern theater. DLecueses, in order, gegaku, noh and kyogen, kabuk1, puppet plays, Chinese musical dance, Ruesian theatrical arte, Japanese vereiono of Western opera, etc. Includes cowneste on the need for a national comprehenelve arte college to upgrade the ekills. The ensaye aleo Indicate the trende of performing arte in Japen. 
Gak1 jơ no 1 eu (Theater Seat)

Toita Yasuj1

Tokyo: Sögenoha

302 p.
㓺場 9椅子

$\dot{户}$ 板康二

刢立社 1952 .

As La PN2921/.T582

A complation of commente on the theater by the author, a drama critlc, wo says he epende a considerable portion of his life in a theater seat. Be loves the theater and his attitude, a a critlc, 18 to diecover laudable pointe in the playe and parformare rather than to search for flaw to deride. From the etandpolnt of a epectator, he presente his impreselone and observations on performances kabukl, noh, Shimpa, etc. and on actore and actresses, namly, Kóh1rō, Ba1kō, Mizutant Yacko, et al. Taubouch1 Yūzō(Shōyō) Tolsyo: Tuzambō 721 p.

A collection of the author's treatises and eseays on drane and 11terature. Couments on subjects such as the fountalnhead of modern literature, renalseance and romanticlea, Ibsen's playe, Chiluanteu and Shakespeare, future of Japanese claselc theater, reason for Japanese Interest in Shakespearean plays, value of Chühhlngura (The Loyal Forty-seven RBnin) a a dram, women and theatrical arts, how to read aodern novele, etc. A rambling account, without any central thene, of the author's thoughte and observations in the flelde of drama and literature.

(Swoke from the Ahtray)

Kimura Kinka 本村金草花 Tokjo: Sagand Shobo 282 p. 相模垔房 1937. As1a R12921/.055

A compilation of random thoughts on theatrical parformances, personalities, etc. Talke about part theater "Angels" and problens Involved in aponooring and etaging how. Notes the personal hablts and profeselonl okills of Ichikawa Sadanj1, Makamara Ganj1rō, et al. Thie work also contains a fairly detailed "Playwright's Gloseary," explaining the epecielized terma used by acript writers.

(Collection of Comentaries)

Roulya Toyotake

Tokyo: Iwanani Shoten

396 p. 
A collection of short commentaries by the author, a dram critic, on the thester and fine arts. Articles Include, "First Impression of Kichlemon," "Puture of Hodern Theater," "On Chekov's Cherry Orchard," otc. In addition to theater, the author comments on art exhibitione giving his evaluations of palntings. 554 p.

Advocates the possibility and significance of this new field called "couparative atudies in drama" and presents h1s methodology. From this standpolnt, he compares Joruri and kabuki with forelgn theater and tries to determine the universal, as well as the speclal, characteristics of the Japanese arte. The work is made up of three divisions. In the firet, the author presents his theory and methodology of comparative atudies. In the second, he compares Japanese arts with Western and in the third, he proceeds to conduct detalled studies of Japanese theater and Hamlet (Japanese version). There is a seque 1 , Zoku hlkalou engekigaku (Comparative Studies in Drama, Supplement), by the same author. 日本と世界9芸能 (Comparative Studies In Performing Arts: Japanese and World Performing Arts) Bd. by Galnōshı Renkyitkn 1 Tokyo: 381 P. Heibonshe 11lue.
芸能史研究会編 1971 . 0, 10

A collection of treatises by various experte to determine the basic characteristics of performing arts, the ignificance of the arts to mankind and the future course of Japanese classic arts. The approach used in the otudy is comparison of performing arts of Japan with those of the otber countries. Treatises cover such subjects as the role of Japanese arts in the history of the world's performing arts, comparisone of Bastern and Western drawn and Japanese parforming arte as seen by forelgners.

91

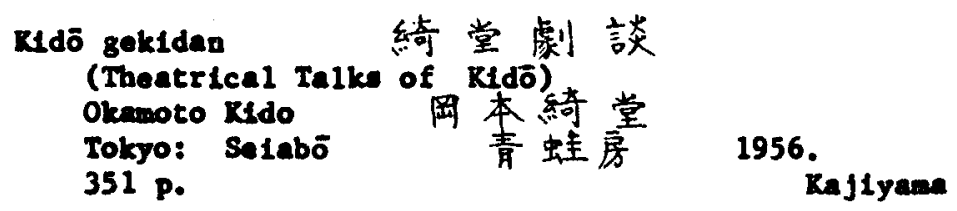


A compllation of essays on the theater written over a period of time, from early Showa period unt1l hle twilight years, by the playwright and critic, Okneoto Kido (1872-1939). Presente his opinions and Iopressions on yose (variety show), ehlbel, kabult, kyögen (classical comedy) and comente on actors and their performances. Being a playright, Kido provides advice on how to wite dranatic plays and recollecte his own creations.

(Commentaries on Yodern Drame)

Rawatake Shigetoshi 河竹慗俊

Tokyo: Ravade Shobō
200 p. (Nihon bungaku talke1, 23 河出房 1938 本文学大系, 23)

A sequel to Kinsel gek1 bungaku (Commentaries on Pre-wodern Dram) by Shuzul Renj1, this work contlaues the discusesion of kabuk1 and puppet playe from 17508 to Wajf and early Talshō perlode (early $20 t h$ century). For those who had not read the earlier work, there 18 an Introductory section outlining the historical developine of the arts. This work describes the flourishing period of labukt and puppet playe, their interactione, full development of dowetic and dance playe, etc.

束京大学出版会 1972 . Al18 27734/.1133

The author aseerts that in the etudy of post-World War II modorn 11terature, dranatic playe had been neglected and that thare is need to serlous iy ovaluate the from a literary otandpolnt. He points out that the etudy and compiletion of history of dranatic plays oed further etrengthening. To ene bis polnt, the author commate on the plays and writinga of Taubouch1 shöyō, Hori Ogal, Oeanal Keoru, et al.

Kurok1 kansō

Tokyo: Rikugolian

534 p.
1929. As1a EN2924.5/..10K8

A compliation of the author's eseare on theatricel arte, primar1ly kabukl and foruri (puppet play), of the Bdo period (1600-1868). Eesays Include "Unlque Quelities of Kabuk1," "Xabukt of the Cenrotu Perlod," "Study of Chikamateu's Plays," "Nat1onal Character of Rabukt," etc. There are articles, also, on the worke of Rino Rnion, Takeda laumo, Bungo-no-jo, et al. 
GERERAL WORKS - COMERTARIRS

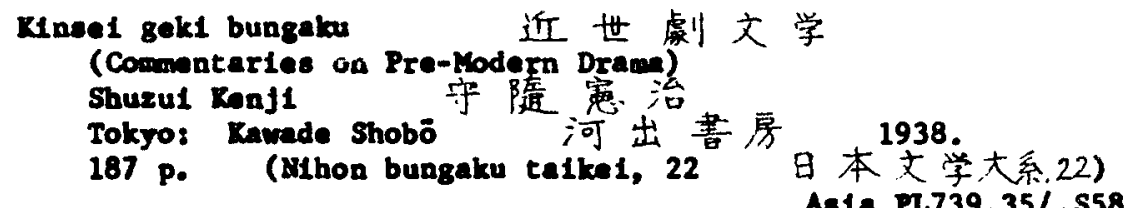

Narrates and comente on drametic arts, with cophas is on kabuk1 and ayetsuri fōruri (puppet play), during part of the Pre-Kodern Age (opecifically, from 1596 to 1763). The work is divided into four perlode: origin of kabuk1 and puppet playe, early developmental stage, growth parlod and frultion. Describes, in stages, how kabukt and puppet plays doveloped into popular theatrical arts. The sequel to this work is Gendal gekt bungaku (Commentes on Modorn Drena) by Kavatake Sh1getoshl.

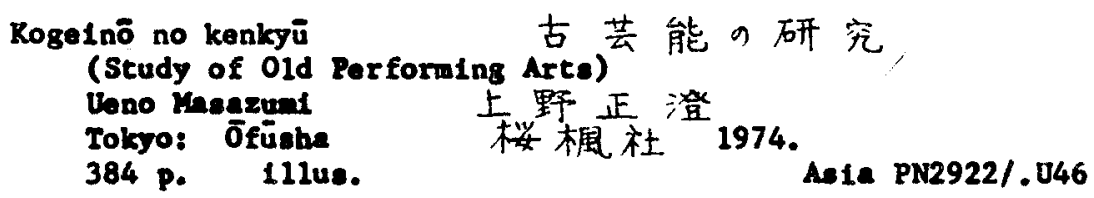

Consiste of two sections: textual narration and source materiale. The texturl section discusses subjects such as: definditive explanations of the word, "performing arte," views toward performing arts in claselc 11terature, genealogies of the birthplaces of performing arte, otudy of the patterno of porforming arts, etc. The source materialo section Includes materials on kalralght (wandering puppeteers), ningyō shlbal (puppet play), chronologlcal liating of materiale pertaining to old performing arta, etc. (Claselc Ferforming Arta: Loed and Kircury) Gunj1 Weakatau 郡司正勝 Tokyo: Mishizame Shoten 西沢店 1975. 414 p. 111us. Ala PN2921/.C83

A sertes of 65 short articles by the suthor proviously publishad In periodicale and nowapapara. The title, "Lead and Kercury," was used in a previoue short article on the heavy factal coswetice ueed by kabukl actors, especlally whon playlng onnagata (femnle imporsonator) roles, and dangers of lead and marcury polsoning. The 65 articles cover atde variety of theacrical subjecte but the underlying theme 1. kabuki.

Wijl gokidan rampa no obita ni te (Hijl Period Tbeater Talks upder the Lamp) Orenowo Ridö Tokyo: Selabö 用本糸堂 361 p. 青蛙房 1965. As 1a PN2923/.037 
GERERAI WORKS - COARAHTARIRS

A compllation of 37 articles by the author on the theater of the Ma1j1 period (1868-1912). Articles wre published from 1920 in the perlodical, Shin enrel (Iow Theatrical Arts). Subjects covered Include actors, mane 1y, Ichilewa Danjürö, Horita Kan'sa, et al., kabukt plays such as Fune Benke1 (Benke1 In the Doat), Opening of the Kabukiza tbater, thoatrical highlighte prior to and after the Busso-Japanose War (1904-1905), etc. This work 1e a repriat of the

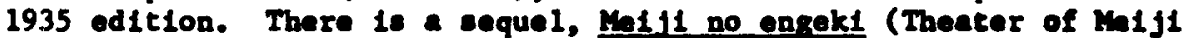
Period).

Malj1 no engek1 明治9 演劇

(Theater of valf1 Period)

Okamoto Kido 周本 綺堂

Tokyo: Dattō Shuppaneha 大東出版社 1942。

290 p. Ala PN2923/.037/1942

There 18 a sequel to Melfl gekidan, rampu no shita nite (Malj1 Perlod Theater Talke under the Laep). Contalne the same articles as the previous work except for a ect1on, "Yoee to hhibal" (Varlety Show and Theater) which was apponded. The title of the work was also changed.

N1hon engek1 kōsatsu (Thoughts on Japanese Theater)

Múake Shütarō

Tokyo: Fuzambō 三宅周太郎

412 p.

山房 1948 .

Written soon after World War II, when the course of Japanase theatricel arte we In doubt, the author ponders the past and future of the arts. Bo presents his views on the beat poselble course for kabukt under the new post-war clrcumstances. Also discusees puppet playe and elves his advice on how to appreclate them. In the concludins section, "Puture of Claselc Theatrical Arte," takes up three kyoren (claselcal comedy) and 29 kabukt plays, Including sukerolu, Suravara denju tenaral kagemi (Sugawara's secrets of call1graphy), etc.

Mthon engekt no kenkyū (Stud1es In Japanese Theaţrical Arte)

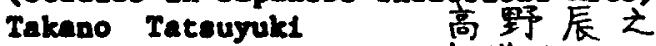
Tokyo: Rateons 改造杜 1926-1928. 2 v. As1a PIR223/.T3

A collection, in two volunes, of the suthor's eseays and lectures on Japanese theatricel erte from enclent to modern tines. Vol. 1 1s divided into two parte: parformins arts and dance, and songe. The first part presente the hietorical background of perforalng arte In the Orient and in Japan, surveys tbe works of Chikenateu Honsacmon (1653-1725), coments on the early forms of kebult and regloanl arte. 
GARRAL WORTS - COMRITARIRS

The second part reports on the development of Japanese songe, Including local folk and the classical-type to accompany noh and kabukf performances. Vol. 2 is also divided 1nto two parts: pre-and postkabuk1 sections. Pre-kabukt section covere bugaku (court music and dance), rōel, shōyō (Buddhist chant), noh, etc. Post-kabuk1 relates In detal the historical developwent of kabuk1 and kyogen (comic Inter lude).

Whon engekt to tono nI 日本演劇とともに (Together with Japanese Theatrical Arts) Kawatake ShLgetoobl Tokyo: Tōto Shobö 270 p. 11lus.

Random articles and essays, mainly recollectlons of the author's 53 years' association with Japanese theatrical arts. Describes his 30 years of professorshlp at Waseda University imersed in the study and teaching of Japanese theater. Recalis his tutelage under Taubouch1 Shöyō, the loss of Mokuani's personal library in the great earthquake of 1923, the visit to bunraku (puppet play) by Princese Alexandra of England In 1961, etc. Also coments on kabuki plays and porformars with whow he soclallzed.

A collection of essays by the author who 18 a scholar on Japanese 11terature. The author theorises that the mother of Japanase 11terature 1s performing arts. The author proceeds to atudy and explain, from a folkloristic standpoint, the problew of transmitting performing arte froa generation to generation.

(Traditonal Parforming Arts of Japan)

Tolaur 1teu Gole1jō

Tokyo: Dallch1 Bôk1

357 p. 111 us.
1973.

As La PL2921/.1R63

An overall beginner' gulde to the traditlonsl performing arts, Including garaku (court mus1c), noh and kyojgen, bunraku (puppet play), kabukl, horeku (Japanase muelc), hobu (Japanese dance), and folk performing arte. With numerous illustrations, explaine the history, types, opecial features, frlende, present status, etc. of asch of the parforming arts. Contalne an Introductory article presenting a senoral hietorical survey of Japanese performing arts. 
GBNERAL WORKS - COMRRIARIBS

105

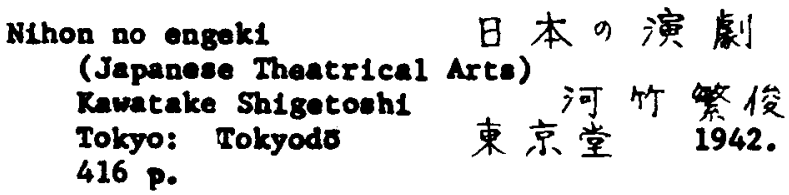

A beginner'. guide to Japanese thanter and parforming arte. Compoed of 3 parts. An abbrevieted hletory of Japanase performing arts is given In Part 1. Part 2 is a record of the dannges Inflicted on kabuk1 by the great earthquake of 1923. Part 3 is a report and critical evaluation of the theatrical arte andet the turnoll of the S1no-Japanese Confilcts of 1930s. Apponded 1s a sort chronological table of performing arte from the anclent times to 1942.

An orlentation gulde to Japanese performing arts. Coaprieed of three parts. Part 1 provides a genaral explanation of the performing arts. Part 2 presents the history, playwights, actors, actins sk111s, choreography, stage propert1es, costume, ote. of the various arts. Part 3 discusses the present status and future outlook of Japapese performing arts.

坪内雄藏、道逢] 早棹田大学出版部 1909 . As 18 PN2923/.T82

A collection of comontaries on dramatic plays, actors, ecripes, Japanese dance and music, otc. The beglnnins section le dovoted to trapslations and coments on Western playe such as "Yarchant of Venice," "Hemlet," etc. Proceeds to writing of pley ecripte and cholr importance In trainins Ideal actors, problem faced by wamp performer: and playurights, present etatus and future of Japenese dance, relationship betwen mulc and 11terature, etc. (Talks about the Theater) Mitamura Bagso Tokyo: Rabuk1 Shuppambu 2 v. 111ue. 
A conpliation, in two volumes, of rambling talks and conents about various aspacts of the theater, Including lebules and noh plays, ralaseo (conic otory-teli1ng), etc. An example is the author': treatiant of Yotsuya kaldan (Ghost Story of Yotsuya). The author questions whether it is actually a ghost story, looke for truthe and falsehoods in the story, etc. There is a brief comentary on the finese of Encho In relating ghost stories in his ralugo.

(Custom and Menners of the Theater)

Mutamura Engyo 三田村煘魚

Tokyo: Kabuk1 Shuppambu 歌舞伎出版部 1928.

312 p. 11lue.

A compllation of the author's theatrical talke pertaining to social custom and manners. Includes articles on bad tastes bred by the theater, significance of fanlly crests of actors, reasone for fow onnerate (fom 1o impersonator) roles in Bdo, etc. Shibal mukashi baneshi
(Rominiecences About the Theater) Bukuhara Rintarō Tokso: Malnichi Shimbunsh $234 p$. 楅原鹿䊅太郎

Reniniscences of the author about his personal experiences with and observatione of the theater between 1913 and 1928 . The author recallo going to Tokyo in 1913 and viewing the plays, "Romo and Jullet," "Saloon," etc. His thatricel intereste include kabuk1 and krören (contc interluda) but his recollections are aninly those of the Japanese modern theater of the cimas. His rentiniscences were pablished in series of articles in the perlodical, Galuto. betweon Jenuary 1972 and December 1973.

111 Shibal sukatcht sanjünen (IhIrty Years of Skatchlng Theatrical Plays) Arak1 Yoohlo Tokgo: Knwade Shobō 河出書房 1938 . 185 p. 111us. As1e P12921/.A735

Por over 30 years, eince the late 1890s, the author had been draving sketches of theatrical playe and performers. This collection of oketches 1o primarily of kabukt plays but includes scenes and actors from the modern theaters of Shimpa, ShinkokugokI and ZenehInza. There are brief rearke explaining the oketches. 
GBRBRAL WORES - COMGRTARIRS

112

$$
\begin{aligned}
& \text { Sugao no engek1jin 素新の演劇人 } \\
& \text { (V1gnettes of Theatrical People) } \\
& \text { Tolta rasuj1 卢板康 = } \\
& \text { Tokyo: Bakusuisha 白木社 } 1956 . \\
& 247 \text { p. Alla PL2927/.T65 }
\end{aligned}
$$

Brlaf blographical oketches, malniy anecdotal, of 32 thoatrical pereonalities, Including actors, playnrights, choreographers and drama critics, associated with kabukt, wodern theater and populer entertalments. V1gnettes are based on the author's parsonal contacts

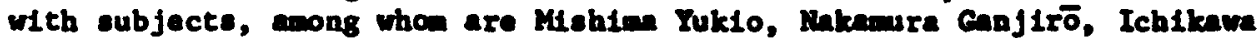
Sadanj1, ot al. (Collection of D Aabe Köson Tokyo: Tokyodo 330 p. $111 u s$.

$$
\begin{aligned}
& \text { 竹9屋劇評集 } \\
& \text { 留 庭案村 } \\
& 1927 . \\
& \text { As 1a BN2924.5/.K3A23 }
\end{aligned}
$$

A collection of drama review by the author, a draan crit1c, published In the Tokyo AsahI Liwepeper between December 1889 and October 1897. The former date 18 the occasion of the opening of the Rabukiza tbeater. Containe review of kabulkt performances at the rabuk1sa, ShIntconlan, Ichtmuraze, Weljiza and other theaters of the pertod. Commes on the performances of such noted kabukt actors as Danjur $\delta$, Kikugoro, Sadanj1, et al. Includes reporte on Tawakami troupe and Shimpa theater and the sudden rise in popularity of Shiopa.

$$
\begin{aligned}
& \text { Abe ruso 阿部僖藏 } \\
& \text { Tokyo: Bngek1 Shuppanuha } 1970 \text {. } \\
& 486 \text { p. 111ue. }
\end{aligned}
$$

Records the extabliehmont, performances and performars of koohtbel (11ttlo theater) In Tokyo. In contrast to the Edo sanse (inicamurate, Ichimurase and Noritase theaters). koehtbel were little, third-rate theaters which were under governent restrictions. In 1872, with government sanction, Edo eange wes Increased to 10 thentars and the restrictions were lifted. The number further increaned in tho Taisho parlod (1912-1925) but beceuce they wre minor thenters, there were inag changes with new onos enarging and old ones disappoering.

2oku engek1 junre1

続演㓺巡札

(P1Igrtange of Theatrica1" Perforinnces, Supplenont)

Myake Shutard Tokyo: Chīō Koronshe 552 p.

$$
\text { 三宅周太郎 }
$$$$
\text { 中央公詥社 } 1941 \text { 。 }
$$
As 1a Pleg21/.M5861 


\begin{abstract}
$A$ sequel to the author's work by the sane t1tle, Enrelst junrel (PLlgrimege of Theatrical Performancea). The previlous work covered the years, 1928 to 1935, and th1s sequel covers 1935 to 1940. Identical in forint to the earlier book, this work is a sarles of short articlas covering the highlights of Japanase theater, with kabulet as the focal point.
\end{abstract}

116 Zoku hiknku engekLgaku (Comparat ive studiea in Drame sur

Cametake Toahio

Tokgo: Nansōaha

$676 \mathrm{p}$.

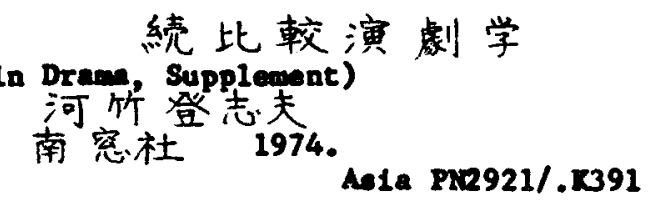

\begin{abstract}
A sequel to the author's previous work, Hlkaka enseklgaku (Comparative studies in Drame). Th1s work re-exandnes h1s wethodologs of comparative etudies in Orlental and Weatern dram and through the comparisons, tries to determin the true and fundamental cherecteristics of both traditional and modern performing arte of the world, wth the focus on Japanese theater. - As in the previous work, this book 1. composed of three divistons. In the firet, author discusses the agnificance and mothodology of comparative studies in performing axts. In the second, he analyzes Japanese traditional arta through comparisone with Western theater, particularly comparison of kabukt wth Shakesperean drase. The thixd section 1 s centered on examination of Japenese modern theater, especlally through the study of the Japanese version of Finlet.
\end{abstract}


GERERAL WORTS - PRRIODICAIS

117

Bnge1 gah8 演芸画報

(Theatrical Arts Plctorial)

Tokyo: Bnge1 Gahōaha 演芸画報社 1907-1943.

v.1-37.

As 12 Pr2009/.J3E63

A monthly 1lluetrated theatrical perlodical, publiahed betwen Janury 1907 and October 1943, for a total of 440 1saues. Succeeded by the Bngek1ke1 (Theatr1cal World). Engel gaho (Theatrical Arts Plctorial) covered the ent1re range of Japanese theatrical arte but the central theme was kabuk1. Several pages of photo 1llustrations prefaced each 1saue. Refer to Engel gahö sösakuln (Indexes to Theatrical Arts PIctorial) for three-volume Indexes to this periodical.

Enge1 gahō aosaku1n 演芸画報統索引

(Indexes to Theatricel Arts P1ctoria1)

Tokyo: Engel Gahosha 演芸更報杜 1974-1977.

3 v.

Aala Ref. PL2009/.E5

Indexes, In three volumes, to the monthly Engel gaho (Theatrical Arts P(ctorial) which was a general theatrical periodical. A total of 440 1ssues were published. Vo1. 1 of the Indexes 1 on theatrical pereonslities, Vol. 2 on plays, scripts and reviewe, and Vol. 3 on general 1tere, particularly of miscellaneous nature which could not be Included in the firet two volume.

119

Engek1gaku 演㓺学

(Studles on Theater Arte)

Bd. by Haseda Dalgaku Engek1 Gekka1 早秥田大学演㓺学会编 Tokyo: Waseds Dalgaku 早稆田大学 1959-1961.

3 v.

An annual papplet on theatrical arts published by the sesoctation for Thester Research, Waseda University. The Initial lesue was published in 1959. Iseues 2 and 3 contaln in English the title, Studies on Theater Arte, and Table of Contente. Ioves 3 Includes art1cles such as, "The Tredition of Drant in 2eanl Joh Pley," "On the Principles of the etyle in Rabukt," "Data and Reaction of Rabuk1' V1e1t to the U.S.A. In 1960," etc.

\author{
Engekika1 \\ (Theatrical World) \\ Tokjo: Bngek1 Shuppansha \\ $16 \nabla$. \\ 演㓺 界
}

演制出版杜 1963-

AsLa F12009/.J3E64 
GEIERAI WORTS - PERIODICALS

An 1llustrated monthly periodical, the successor to Engel gaho (Theatrical Arta Plctorial), wth a inllar formet. Began pubilcation In tovenber 1943, the month after 1ts predeceseor cessed publication. Written for theater-goers with the Intent of deepening their appreciation of the theatrical arts. Publishes special editions, such as the June 1979 1ssue which 1s a "Gulde to Fanoue Kabukt Plays," with synopese and comments on each play.

121

Engok1 nempö演虔年報

(Japapese Theater Annual)

Bd. by Heseda Dalgaku Engek1 Hekubuteukan 早䊈田大学演㓺博物館編 Tokyo: Chürasha 中和社 1971-

9 v.

As 1a Pr2920/.B49

An annual, recording the highlights of the varlous theatrical arte during the previoue year. The 1979 Engek1 nompo (Japanese Theater Annual) 1s the 14th in the serles and covers 1978. Begins with ctage pictures and proceeds to the main section, currents and trends of kabukl, noh, puppet plays, contemporary theater, etc. Includes obltunries of leading theatrical personalities, record of theatrical performances and bibllography of perlodicals and booka.

(Performing Arte)

Bd. by Gelno Gakke1

Tokyo: Ga1nō Bakkōjo

12 v.

荎能学会

芸能発行方公 1961-1973.

As 1a PK2921/.045

A wonthly periodical, as wil as the orgen, of Gelnō Gakkal (Performing Arts Acadealc Soclety). A comprehenelve perlodical on the study, exnmination and reviow of present-day performing arta. A scholarly pablication Intended to aseist in cultural and folkloristic studies of parforming arts. 
GBMERAL hORKS - MIScBLLAKEOUS

Butal b1jutsu o kangaeru

(Thoughte on Stage Art)

Oda Otoya 䄉田音世

Tokyo: N1hon Hoso Shuppan Kyoka1

246 p.

舞台美術を考之る

Of the elemants that make up theatrical arte, the author defines stage art as "that alewant which can be seen by the opectators," that 1s, the stage scenery and properties, the actors' hand prope, costumes and make-up, etc. that the audiance sees when the curtain goes up. In this sonse, the author states stage art has a broader meaning than stage-setting. Th1s work is an anslyeis of stage art, $1 t 8$ or $1 g 1 \mathrm{n}$, changee and development over the years, techniques Involvad, Ignificance to the parformances, etc. Photo 1llustrations of the author's stage creations are also included. Complenents "the vork," Butal sochl no kenkri (Study of Stage-sett1ng).

(Study of Stage-setting)

Itō risału

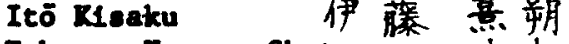

Tokyo: Koyame Shoten 小山書店 1941.

226 p. 11lus. Asta PH2091/.s8186

A oystematic study of atage-setting with explanations on the technical aspects as wil as on the artistic and theatrical functions of the stage. Describes stage conetruction, types, rapld eet changes, entrances and exits, thage properties, hand props, costumes, IIghting and use of mode1s in designing. The chapter titled, "Gloseary of stage-setting Terms," comprises a good part of the work and provides clear and brief definitions of terms related to every aepect of the stage. Illustrations are Included. Bnglish terme are aloo used in the gloseary and 11 lustration. A useful reference for staging performances and for Increasing appreciation of the theater.

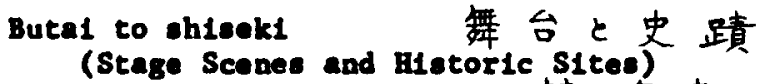
Bayasht Tougltade Tokyo: Asah1 Shimbunsha 林次忠 211 p. 111us. 朝白新聞社 1930. Ala PN2924.5/.K3H39

Stage scenes of 82 places, which appear In 10rurt (puppet play). kabuk1 and Sh1mpe, are show togethar with photo 11 lustrations, dated 1930, of the actual stes. Provides an interesting contrast, at one glance, of the theatrical ecene and hietoric elte. Thoto 11luatretions first appeared in the Acaht Gurafu. 
Dotombor1: kawe, hash1, shibal

(Dotombor1: River, Bridge and Shibal)

Mta Jun'1ch1 三田純一

KFoto: Sh1rakara Shoin 1975.

301 p.

Asia PK2926/.08K5

An Informal, historical narrative of theatrical activities in the Dotomborl district of Osake by an author who wes born and raised In the erea. Centered on the five anin theaters in Dotombor1, the work traces the viciestides of shlbal (theater) performances and popularity in Oeake. Provides beckgound local color of the area wth descriptions of restaurants, stores, actors' home, etc. along the Ditombor I river. (Soloctlons of Modern Drant Ie Plays) Kishida Kunio Tokyo: Ravade Shobs 5 v. 111us.

$$
\begin{aligned}
& \text { 岸田国士[他] } \\
& \text { 河出妻房 1951。 } \\
& \text { Asta PL769.65/.038 }
\end{aligned}
$$

A collection, in five volumas of 35 modern dramatic plays, writcen betwen the late 1920 s and late 1940s, by 33 different playwrights, Including Mehten Yukto, Kishida Kunio, Kubote Mantarö, et al. At the end of each volum, there are brlef explenatory notes and aynopese of the plays uritten by noted ctitice.

A serles of elght volumes of dramatic playe published and/or performed between 1946 and 1971. Vo1. 1 contalns plage between 1946 and 1949 wile Vol. 8 bae playe betwen 1969 and 1971. Includes plays by Kubota Mantarō (1889-1963), Mishina lukio (1925-1970), Abe Kobs (1924-), et al. At the end of each volume, there 1s an eseay covaring theatrical highlighte for the perfod, an annotative section glving the arnopees and explanatory comments on each play, and a chronologieal listing of author, play, perlodical in which published, first performance, remeric and historic sidelighte.

Gonde1 no 1enoto (Present-day Ieroto) Mishtyana Minteunosuke Tokyo: robundo 236 p.

$$
\begin{aligned}
& \text { 現代9家元 } \\
& \text { 弘西堂山松之助 }
\end{aligned}
$$

As1a PX2924/.857 
GELERAI HORKS - MISCELIANBOUS

A sequel to Ienoto nonosater1 (Story about Ienoto) published in 1956 by the eane suthor. This work delves further Into the social. cultural and hietorical factors in Japenese society wich make the lomoto (hoed of a school) syotem fulfill a significant role. This work concentrates on the lemoto system in Japanese dencing, kouta and noh. Also, discusses the pros and cons of the syeten and the different types of 1emoto.

130

Ba1yū teū 俳倭 通

(Expartise on Actore)

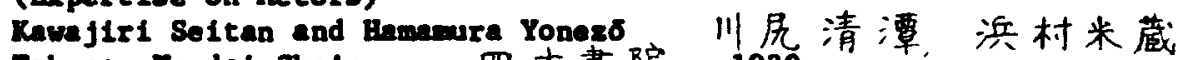
Tokyo: Yonda1 Sholn 四大書院 1930.
154 p.

A book about actore witten with the intent of Imparting knowledge that would help one becowe an expart on ectors. Contains four parte: lives of actors, today's actors, history of Japanase actore, and tomorrow's actors. A readable book with anecdotes about Onos Kikugorō, Ichikawa Ennosuke, Morl RLtauko, Msutanl Iaeko, et al.

131

Iewoto monogatar1 家元ものがだ

(Story about Iomoto)

Niohiyama Hatsunosuke 西山松之助

268 p. 111us. Aisa DS827\%.I35N57

Discusese the unique Japanese social system of lemoto (head of a school) which is commoly aseoclated with different echools of dencing, me1c, etc. The euthor, wo had conducted over 10 years of research on this subject prior to pablication of this work, states that although the 1emoto syoten has been criticised as foudalietic and undemocratic, now lenoto et111 appear today. This work annlyces the establiabment, organiention, epecial characteristics, tranenittal,. etc. of the ienoto syeten in 18 different fields, Including rese ongaku (off-atage mavic), ragaku (court music). itchü-bughs, etc. Thare is - seque 1, Gande1 no iceoto (Present-day Ieroto), by the esme suthor.

ranteiryū kyōbon 勘亭流教本

(Text on Kantel School of Calligraphy)

Takeobiba Kanisuke 竹梀留助

Tokyo: Gurafikkuohn

148 p. 111us. Asia Br3637/.T34

The Rentel etyle of calligraphy we doveloped for writing the biliboards, bensuke (playb111), atc. for ehlbal (thoater), notably kabuk1, and is still belas used, not only for ahtbel but all types of elgns, posters, advertisements, etc. This is a text, iritten by a Tantei school calligrapher with 50 years of experfence, and axpleins the origin of the school and actual techniques used in the calligraphy. 
GBRERAL WORTS - MISCELLANEOUS

133

Me1ji shigekishū 明治史劇集

(Collection of Hetorical Playe of Mijl Pariod)

Tolta Yasuji $\mathcal{P}$ 板康二

Tokyo: Chikuma Shobo 1966.

451 p. 1llus. (Malj1 bungaku zenshü, 85 明治文学全集,85)

Asia PL755.6/.245/v.85

A collection of 17 historical playe written by 10 different playrighte during the Wifl period (1868-1912). Included are playe by Wori Ogal, N1chlren Shönin tauli seppö, by Okanoto Kidö, Iahin zeneo, etc. Photos of the playwrights are presented at the beginning of the work. at the end are an article by Tolta Yasuf1 on "Various Factors Affecting Keif1 Historical Plays," Interpretative coments on the 17 plays by the same author, blographical sketches of the 10 playwrights, and a Liat of pablicatione on Mijl historical playe and on the playnrighte themselves.

134

Nhon butal shöntsht (History of Stage I

Bd. by Ogawa Moboru Tokyo: Nihon Shöme1ke kyōke1

日本舞台照明史 173 p. 111us.

A detalled historical account, In chart form, of the developwent of stage Itghting in Japanese theaters. Covers the period from 1384 to 1926. Theater structures replaced outdoor etages but natural light was let in and no records exist of when artificlal lighting began to be used. However, In 1714, a goverment decree forbade night performances and the use of 11ghts, indicating that sow for of artificial lighting had been used prior to that. In 1780s, candles placed on stande were used. Torchlights also came into use followed by oll lampe and gaslight. Arc lights from genarators were flrst reported ueed in a Dötomborl theater in 1884.

(Complete Works of Japanese Dramat1c Plays: Modern Bdition)

Ed. by Truboucht Shoyd

Tokyo: Shun' yodo

$17 \mathrm{v.} \mathrm{11lue.}$

(Wihon slkyolus zenshū, 33-50

日本戱曲全集, 33-50)

As 1a PL764/.1555/v.33-50

The Gendal-hen (Modern Bdition) serfes consists of 17 volumes, Vols. 33-50, of Bthon sikrolon zenshü (Cosplete Works of Japanese Drametic Plays). Vol. 33 is Genda1-hen dalieshü (Collection No. 1), containing the plays of Trubouch1 Shoyo (1895-1935). Other noteworthy voluene are: Vol. 34, Collection 10. 2, Oknnoto Kidō (1872-1939); Vol. 43, Collection No. 11, Shimamura Bögeteu (1871-1918); and Vo1. 48, Collection Bb. 16, Kishida Tunio (1890-1954). Bach volum is a collection of plays with brief eynopes and explanetory reaniks. Also Included are the playrright's portrait and photos of stage scenes. 
GBNERAI WORRS - MISCETIANEOUS

136

Nhon no men

(Macke of Japan)

Kancko Byōun

Tokyo: Chikune Shobō

128 p. 111ue.

日本の面

A follo-elzed collection of photos, nostly full-paged black-and-white and a few in color, of 152 make used in performances of giselu (court mus1c), buseku (court waic and dance), grödo (Buddhist ritualiatic proceseion), noh and brögen (claselcal conedy). There 18 a narrative section, following the photon, explaining the origin, - Ignificance, epecial features, etc. of each performing art and the types and descriptions of masks used. Bach of the 152 maske is aleo explained. Apponded is a claseified Inglish listing of the aneks, noting the designation and possessor. A compect version, kamen no b1 (Beauty of Masks), was publiehed in 1977, containing 135 photes of the same make photographed frow different angles.

137 Hhon no ryümin 8 日本9流民芸 (ItInerant Rerforming Arte of Japan) Kamate Tadayosh1 忠良 Tokyo: Shin Jimbuteu Oraisha 1974 . 319 p. 111us. Alis PN2924/.124

Deplete the ltinerent performing arts of various reglon of Japan, Including the Tougaru jamisen players of Aomori prefecture, eldeshow performere of Acakues in Tokyo, shibal (theater) players of Okinawn, etc. A descriptive narration in which the author tries to deternin the cultural eignificance of these vagrant theatrical arta. 人間国宝.

(Living National Treasure)

Tokyo: Yomitur1 Shtmbuncha

261 p. 11lus.

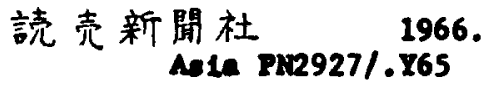

A collection, as of 1966, of parson designated by the Japapese government as Intangible Cultural Anset or "Living Rational Treasure" in the fielde of parformins arts and handcrafte. The honored individuals and their worke or arts are introduced with photographs and narratives. In performing arts, 38 Individuals were selected from noh, broren

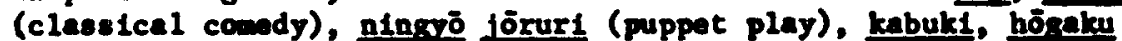
(Japanase mulc) and buró (Japanose dance).

Oke Oaitaró den (Biography of Oke Onitard) Takeshita Bilcht Tokyo: Seiabs 366 p.

$$
\text { 青蛙房 } 1969 \text { 。 }
$$

$$
\text { 青蛙房 1969。Ae1a CT1838/.043734 }
$$


CERRN WORTS - MISCLLWANOUS

Blography of dran critic and playmighe, Oke Onitaro (1872-1934). After greduating from telō Univerelty, Oke becase a drane critle for the newepapers. Ho left the aswepare to aselot Ichikawa Sadanj1 II (1880-1940) in staging new and wodern theatrical plays at the Wijlen theater. With Sedanj1, he later entered Shöchiku and also becsine fancus as a director and parformer. Ho was also one of the first leadare of a research society on rakugo (comic story-tellins). Appended to this work are liets of his publications and playe.

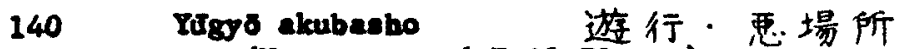
(Vagrancy and Bvil Places) Hirosue Tamoteu 広来保 Tokyo: Mraisha 未来杜 1975. 264 p. 11lus. Anie P2R924.5/.R3H53

A treatise on ghibal (theater), Including discussion of how parformers and shibal were once regarded by the government and uppar claseses. The vagrant performara were regarded as lowly outcasta and shibal and prostitute quarters were lumped into one as evil places. The wthor polnte out foudalietic government discrialnation againat parformars and shlbei. 
KABURI - GENERAL

141 Asakuse sarumake-cho (Sarumaka-chō in Aeakuea Distr1ct) NiIn Iakesh1 Tokyo: N11mi Shoten 223 p. 111ue.

$$
\text { 浅草猿若町 }
$$

$$
\text { 新美高店 } 1973 .
$$

Aria $0 S 896.7 / .526 P 84$

Records the beginnings and traces the changes of Saruwakn-cho in Asakuse district, Tokyo. Saruwakn-cho was the thriving center of kabuki from 1840. to 1890 with the "Snirumen Three Theaters" of Makamure, Ichimura and Tawarasaki (later Worita) theaters. Ralates the history of the area, presents the recollections of sctors and persons associated with the theater district and describes thie section of Asakuea os it exiots today.

142 Butal kansateu tebik1gusa (Gulde to Observing Stage Performances)

Sug1 Gan' and

Tokyo: Gesbungha 柇噟阿弥

每台矮察手引草 415 P.

1919.

As 1a PN2924.5/. 33584

A collection of articles wich appeared in Engel gahō (Drana Plctorial) from 1913 to 1916 . Comants on 10 principal charactere who appear In representative aruhon kebuki (Jörur 1-based kabuk1) plays. Characters include Watōnal, hero of koleusen'ya kaesen (The Battles of Coxinga), Mateuomaru from Suserara denfu tenaral kegami (Sugavara's Sacrets of Call1graphy), otc. Provides background information on the roles and interpretations of how the role should be played. Presents helpful hiats for actors performing the roles.

(Basearches on Chtkanatsu, Mamboleu and Moluand)

Waseda Bungakusha 早稻由文学社

Tokyo: Tokyods 束京堂 1929.

1 v. 11lus. Asia PL793.4/.W38

A collection of three lesues of the periodical, Weeda bungaku (Weseda IIterature). The liovaber 1926 leave (250th annivereary edition) is devoted to the etudy of Chiknantev Yonenemon (1653-1725) with 16 articles by noted theatrieal writere, nevely, Teubouch! Shöyö, Kitani Högin, Turoki Ranzō, et al. Ith July 1927 Lesue is a etudy of Touruja Bambolv IV (1755-1829) and Enwatake Moluand (1816-1893) with 15 articles by Ateund Saltard, Shusul renj1. rawatale Shigetooh1, at al. The October 1927 isoue covers kugazoshi (Illustrated Popular stories) and discuses its origin, growth, characteristics, etc. 
RABURI - GENERAL

144

$$
\begin{aligned}
& \text { Chüshingura 忠臣菬 } \\
& \text { To1ta Yasuj1 } \overline{\text { F }} \text { 板康二 } \\
& \text { Tokgo: Sögensha 創元社 } 1957 .
\end{aligned}
$$

236 p. 111ua. As1e PL737/.T6

Explains the famous kabuki play, Kanadehon Chüshingura (The Loyal Forty-seven Rōnln) with ample 11lustrations. Serves as a handbook not only to appreclation of this particular play but to kabuki plays, in general.

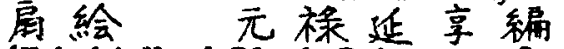

(Kabuki Wood Block Prints on Japanese Hand Fan) Ed. by Kimura Sutezö and Myao Shigeo 宫尾しげ放編

Tokyo: Inoue Shobō

134 p. 111us.

$$
\text { 井上音房 } 1962 .
$$

A collection of reproductione, with explanations, of 43 kabukt uchiwae (wood-block prints on Japanese hand fan) from the Genroku perlod (1688-1703) to the Enkyo period (1744-1747). Many of the plctures were drawn by Torll Kiyoultsu who is sald to be the originator of kabuki color prints.

$$
\text { Engek1, PekIn-Tokyo 演虔 - 北京一東京 }
$$

(Drama: Peking-Tokyo)

Tolta Yasuf1
Tokgo: Murayama Shoten 板康 $=$
266 p. 村山专店 1956.
Asia

Asia Pr2038/.T64

Consists of three sections: 1. Articles on the October 1955 trip to the People's Repubilc of China by the kabuki troupe led by Ichlkawe Ennosuke (1888-1963) and accompanied by the author, 2. Reviewa witten wen the author participated in the publication of the lith newepaper, and 3. Essays on his expertences as a drane eritic.

Eng1 no densho 演技 9 伭承 (Observations on Theatrical $\Delta x t$ ) Rawaj1r1 Saitan 川层清潭社 1956. $234 \mathrm{p}$.

Al1a PIR924.5/. 2313386

Contains the posthumoue works of the author who was known as a kabuki critic and researcher. Unlike other scholarly stud1es of kabule, this collection of articles is based on the author's personal observations, reactions and experiences while associated with the kabult theater. Consists of comantaries on perforwances 
RABURI - GENERAL

of notable kabuk1 plays, Including Chühingura (The Loyal Fortyseven Rōnin), and gere ongaku (off-stage music). (Study of Conroku Period Kabuki)

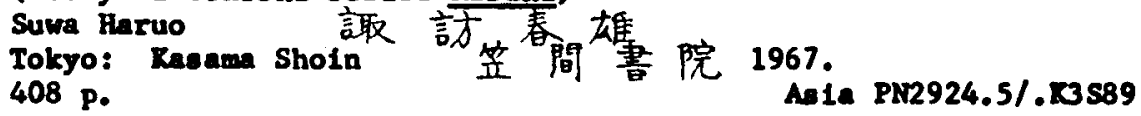

Examines the origin and growth of Genroku kabukt performed during the Genroku period (1688-1703) which was considered the most flourishing period. Attempte to interpret the role and ignificance of Cenrola kabukt in the development of modern theatrical history. Includes a detailed chronological account of the Iife of Ichikawe Danjurro I (1660-1710) with comentaries on his performances.

$$
\text { Hatyūron 俳 優 論 }
$$

(Observations on Rabuk1 Actors)

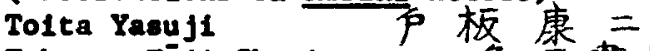
Tokgo: Tōj1 Shorin 冬至書林 1942. 290 p. As 1a PN2927/.T58

A serles of articles, published in varlous periodicals, on the author's observations concerning kabuk1. Talks about several, famous modern actors, namely, Onoe Rikugorō VI (1885-1949), Nakamura K1chtemon II (1886-1954), et $\&$, and comments on their personalit1es, acting atyles, noteworthy performances, etc. Includes a gloseary of kabukf term with simple but fairly detalled explanat 1ons.

Chronologically 11sts the kabukl parformances staged at Edo theaters, malniy Ichtmurasa, Nakamuraza and Moritaza, between Kan'el 1 (1624) and Bunke 1 (1804). Gives the names of playe, actors and roles, and the popularity of plays and actors. Includes sketches of stage scenes and quotations of hit lines of actors. A basic source material for study of kabukt.

151 Hengeron: kabuki no selohinah1 变化論一歌舞伎9精神史 (Transformation Theory: Spiritual History of Rabuk1) Rattor1 Yuk10 Tokyo: Helbonsha 269 p.

$$
\text { 服部辛雄 }
$$$$
\text { 平凡社 }
$$

1975. 
The classic performing art of kabulk preserved 1ts traditional acting pattern and techniques but the actors' performances Inevitably reflect the opiritual beliefs and living conditions of the times. Thus, the author examines kabuki from a spiritual standpolnt. The author belleves that in its historical evolution, kabukt has lost certain spiritual values, the wost important of which is the Buddhietic out look of the world.

Hanshin no shisō: Nihon engek1 n1 okeru engi no riron 变身思想一旦本演㓺によ゙ける演技の理論 (Thoughts on Transformation: Dramaturgical Theory of the Japanese Theater) Imao Tetsuya 今尾掊也 Tokyo: Hose1 Datgaku Shuppankyoku 324 p. 111 .

法政大学出版局 As 1a PN2921\%.IA

1970.

The author expounds the theory that in kabukf, as in actual society, thoughte and actions are subject to change and the transformation process is an essential element in the composition and development of kabukf.

Jisetsu shibatbansoht

$$
\text { 実説芝居ばなし }
$$

(True Theatrical Stories)

Mitamura Engyo

Tokyo: Selabö

328 p.

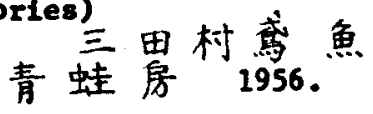

As 1a DS896.5/.M58V4

Examines the historical truths of well-known characters appearing In kabuki plays and inquires Into the historical circumatances of the period, primarily Edo, In which they lived. A supplewantary edition to the author's earlier work, Shibal to shifitsu (Theatrical Rlays and Hiatorical Truthel,

Rabuki
Ed. by Gunji Masakatsu

Tokyo: Galarge1 Shorin

郡司正勝編

学苔書林 1976 .

200 p. 1llus. (Dento to genda1, 4 伭統と現代，4)

As1a PN2924.5/.Ḱ3G85

A compllation of miscellaneous essays on kabukt. Discusses prominent actors, thelr acting patterns, genealogical background, popularity, etc. Covers historical aspects of kabuki for the pre-end post-World War II. periods. Points out the relative importance of kabuk1 In the daily lives of the people. 
1956. Alsa PN2924.5/..338351

The author, who 1s a drama critic, atudies kabuk1 frow three different vieupoints. Piret, he tries to analyze the fundemental characterletice of kabuk1 by considering the theme and composition of plays, the acting techniques, the performances of great actors, etc. The author believes that though kabuk1 is a highly stylized performing art, it is realietic in expression and reflects the changing times. Second, dissects the acting pattern of Onoe Kikugorō VI (1885-1949) and commente on his contributions to kabuki. Th1rd, he recounte the October 1955 trip to the Peopled Republic of Chine by the troupe of Ichikewa Bnnosuke (1888-1963) and recalls the International appreciation of theatrical arts.

歌 舞伎店

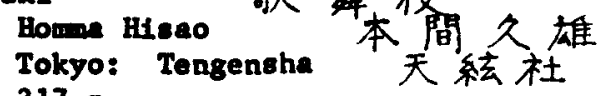$$
317 \mathrm{p} \text {. }
$$

1947.

Asia PN2924.5/.K3H65

A collection of theater reviews and impressions published in the Engel gahō (Drama Pictorial) and Kokumin ehimbun (People's newspapar) by the author from $1920 \mathrm{~s}$ to 1940. The kabuk1 world 1. comonly regarded as a oupernatural one, coobining fantasy and pictorial beauty, but the author points out that it is a realietic Image of soclety.

157

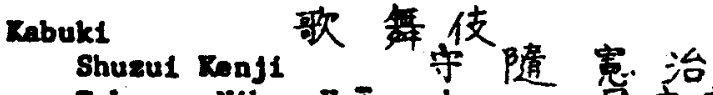

Tokyo: Nihon Hyöronsha 百本䛨論社 1943.

373 p. (Zoku Nihon koten dolwhon,9 絰日本古典境本，9） Asia $\mathrm{RL767/.848}$

Compriced of two parts: "Yain Text" and "Research". In the "Main Text" section, the etage scripts and explanatory comente of two play are given, Releel Jagatarabumi and Sukeroku rukart no Bdozakura. In the "Recearch" section, four short essays are presented, including the compostition of a kabult play, hietorical and donestic playe, otc.

Tabuk1 bukuro (Labuls Grab Bag) Gunj1 Meakateu Tokyo: Solabō 355 p.
か及゙き袋

郡 司正幐

青蛙房 1970 。

Asia PN2924.5/.13682 
RABURI - GENERAL.

A miscelleneous collection of articles which had appeared earlier in partodicals and newepapers over a epan of time. Begins with a short section describing various props, costumes, stage settings, etc. used in kabult. Proceeds to discussion of different plays and comparisons with other performing arts, such as noh, yökrola, etc. Presents tidbits on Truruya Namboku IV (1755-1829). Concludes with a rather lengthy section on local customs and mannere concerning the performing arts.

Kabuk1 dang1 歌 舞伎談義 (Discourse on Kabukt) Okamoto RIdö Tokyo: Selabo 岡本绮 堂 329 p. 青蛙房 1957。 Rajlyana

A series of easays on various aspects of kabuki by an author who was also a playwright and drame critic. Intended as an orientation guide to kabuk1. Chapter 2 is devoted to the sudy of the $11 \mathrm{fe}$ and works of Kawatake Mokuemi (1816-1893).

Rabukı e no shōta1

(Invitation to Kabuk1)

Tolta Yasuj1 Tokyo: Ishō Rankyūjo

218 p. $111 \mathrm{us}$.

歌舞伎入9招待

今 板康二 衣裳研究所 1950 .

Asia PN2924.5/.R3T6

A concise, beginner's guide to kabuk1. Varlous aspects are discussed under 13 subject headings, Including actors, stage properties, etc. Polnts out the significance of kabukt and its contributions to theatrical history. To explain secial characteristics, cites specific kabukt plays and actors' performances. Explanations given in simple term and with 1llustrations.

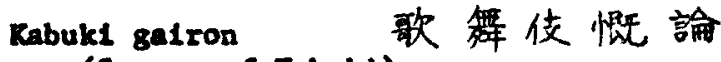

(Survey of Kabuki)

ILzuka Tomotchirō

Tologo: Halabunkan

669 p. 111us.

㙛文增友一郎

As1a PN2924.5/.K3I38

Bxplains how to appreclate kabukf performances and analyzes the developint of kabukt. Discusses kabukt as a cultural aspect of the Bdo pariod, follow its growth to a national art and describes 1te role in the theatrical history of the world. Covers the unique features of kabuki, Including the ectore and their lives, performance styles and production methods, stage-settings and costumes, etc. A useful raference for research on kabukt. 
RABURI - GENERAL

(Illustrated Hietory of Rabuk1)

Tsubouch1 ॠüzō (Shōyō)

Tokyo: Tokyodo

256 p. 111 lus.

東 京堂

坪内雄藏道连了

1931 .

As 1a FN2924.5/.R3T82

A treatise on kabukf by the noted playwright and drama crit1c, Tsubouch 1 Shōyō, who first introduced Shakespare to Japan.

Discourses on the historical development of kabuk1 from onna kabuk1 (women's kabuk1) to wakaghü kabuk1 (boys' kabuk1) and so on, changes In the construction of the theater and stage, etc. Includes an article on the colncidental simllarities between kabukt theater and Shakespearean theater, an article which can be considered unique at the time it was witten In early Showa period. Host of the articles were first published in the now defunct parlodical, Nishikie (Color Print).

Kabuk1 ge1 juteu

(Kabuk1 Art)

Dazal Shimon

Tokyo: Sense1do

334 p. 111us.
歌 舞伎芸術

$$
\text { 太宰施阿 }
$$$$
\text { 三省堂 } 1942 \text { 。 }
$$

As 1a PN2924.5/R3039

Describes the epecial properties of kabuk1 which makes it a parforming art to see rather than to hear and contraste it with the theatrical arts of other countrles, particularly France. Delves Into ite relationahipa with dramatic literature, the roles and performances of famous actors and the noteworthy points of representat Ive kabuk1 plays.

Kabuk1gek1 g1kyoku kōzō no kenkyū 歌舞伎膚戯曲構造の研究 (Compositional Study of Rabukt Dramas) Shuzul lenj1 Tokyo: Bokuryūican 北隆 館 1947. 290 p.

AsLe PN2924.5/.R35581

A theoretical analysis of the composition of kabuk1 plays and In view of the complextities of the plays, a rare endeavor. The author firet breaks dow and Identifles the peculiar qualities and source materlals of kabuk1 plays. He then presente h1s structural theory besed on a eurvey of the historical devalopwent of kabukt. He proceeds to annlyze acts and scenes in the play and concludes with studies of the stage Instructions and dialogs used by the actors.

Rrbuk1 gek1jô onnagata fūzola salken

歌舞伎虔埸女形用俗細見 (Scrut1ny of rabukt Theater Onnagata Custow and Manners) Adacht Raoro Tolyo: Tabōeha 350 p. $111 \mathrm{us}$. 足立罣郎

展望社 1976 。 As1a PH2924.5/.133133 
KABURI - GENERAI

Covers three toplcs: 1. O rganlzat 1on, management, stage settings, costume, performences, actors, audience, etc. of theaters in Ido and Osaka, 2. Histortcal survey of the developent of modern kabuks. 3. Origin and growth of onnagate (femile imporsonator) roles in Edo kabuk1. The onnagata subject is discussed in detall, by different historicel perlode, between the 17 th and mid-19th centurles.

Kabuk1gek1 no mikata
(How to Apprec1ate Kabukt)
Hamamura Yoneró
Tokyo:

As 1a PR2924.5/.K3H35

Stresses tha value of kabukt as a masical form of theatrical art. The book is made up of two parts: 1. "Theory of Values" in which the h1storlcal background and developments of kabukl are discussed, and 2. "Study of Dram and Stage" In which stage effects, particularly maical accompaniment, and representative kabuk1 plays are considered.

Rabuk1 geza ongaku (Kabuk1 Off-stage Malc) Moch1ruk1 Te1nosuke Tokyo: Engekt Shuppanehe 323 p. 11lus. 歌籍伎下座音集

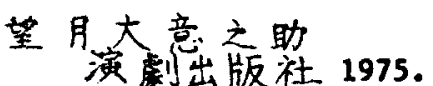
As 1a ML1751/.J3H6

Presents a detalled coverage, the firat book of 1 ts kind, of kabukt geza ongalu (kabuk1 off-stage ma1c). Describes the musical Inctruments used, the types of Ingling and chanting for different playe, sound effects and timing, etc. Discusses the role of walc in kabukt, wich is a performing art combining music, dancing and acting. Serves as a reference when staging labuk1 performances.

Rabuk1 hakken 歌舞伎笔見

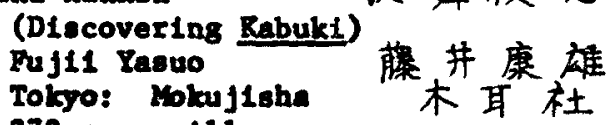

372 p. 111 us.
1971.

As ia PN2924.5/. K3784

The author ponders the quest10ns, "What 18 kabuk1 and what are 1 ts values" In his quest, he gaine a new Insight which he claims added a now dimeneion to his 11fe. He tries to explain his new oat look through three avenues: 1. Compliling the vievs of noted kabukt critics, nemels, Tsubouch1 Shöyō, Osanal Raoru, Mílyake Shataro, et al., extolilng the expreselve, stylized beauty of knbule1. 2. Revealing the feellngs, sentioents and sense of beauty of the Japanese poople through the writinge of Chtkenatsu Monzacwon (1653-1725) and acting of Nakamura Ganj1rō II (1902-) ), and 3. HL comonts on scenes, roles and performances whlch he found pratseworthy. 
KABURI - GENRRAI

$$
\text { Kabuk1 hana to mi 歌舞伎花七实 }
$$

(Kabuk1 Plowering Basence)

Bandō Mitaugoro 坂 束三津五郎

Tokyo: Tamagava Dalgaku Shuppambu

1976.

262 p. 11148.

王川大学出版部

As1a PN2924.5/..13827

A collection of art talks and essays on kabukt, as well as personal anecdotes, of Bandō Mtreugorō (1906-1975), a prond nent kabuk actor and the head of the Bando School of Japanese dancing. Complled by Tamagawa Univereity where the author had served as professor emeritus.

170

Rabuk1 hyakuda1

歌伎百題

(One Hundred Kabuki Topics)

rasratake Shigetoshi

Tokyo: Se1abō

青蛙房河败俊

307 p.

A collection of one hundred articles selected from the author' essays on kabuki and bunraku (puppet play).

171 Rabuk1 hyakushu

(One liundred Rabukt Playa)

Dömoto Ranse1 堂 本塞 星

Kyoto: Rawara Shoten 河原妻店 1949.

298 p.

As 1a PLR924.5/.R3D652

A gulde, consisting of two parts, to the appreclation of kabuki. The firat part is called, "Overview of Kabuk1," and expla1ns the performing art of kabukt. The second part, "One llundred Kabukt Playe," is a selection of 100 playe, malniy taken from puppet theater plays, and Includes coments on the playurkght, firet performances, outline of plays and interpretatione.

(Collect1on of Rabuk1 Critical Booklets) Ed. by Rabuk1 Hyobank1 Kenkyluka Tokyo: Iranami Shoten 岩波要店

歌舞伎評判記研究会編 11 v. 111us. 1972. Asta PI2924.5/.23123

A collection in 11 volumes, of 110 odd lenbukt criticel booklets lesued during the firet half of the modern kabuk1 perlod. Begles with the Yarömight, published in 1660, and concludes with Yaluihe ogl no mato, published in 1735. Arranged chronolog1cally w1th IIlustrations of ectors, stage scenes and actors' crests. Presents the rating to an ector, roles he played, critique of his ok111s, etc. The 11th volume contelns supplewentary booklete and Indexes of actors, stage personelities and creste. 
(K-buk1: Costumes and Make-up)

Söma Ak1ra and Tor11 Kiyonobu

Tokyo: Dal Nthon Yubenka1 Kōdancha

1957.

172 p. 111us.

歌舞伎一底裳と扮装

相馬皓著岛居清信要

大日本雄命会撞詇杜

As1a FO X PN2924.5/.R3S6

Presente a historical view of the changes in kabukf costumes and make-up. The relations between an actor's role and his make-up are explained with the use of original color photographe and printe.

Rabuk1 1zen

(Before Rabuk1)

Hayash1ya Tatsusaburō

歌舞佒し火前

Tokyo: Iranami Shoten

253 p. 111us.

林屋辰三郎

岩波糟店 1964 。

As1a PIR922/.H37

Explains, in simple terminology, the various types of performing axts which existed from the late ancient age to the beginning of modern times when kabukt was born. Also explains, with the focus on theatrical arts, the history and living conditions of the people and soclal circumstances of the times.

175

Tabuki j1ten

歌舞伎 事典

(Kabuk1 Randbook)

Ed. by Kamatake Sh1getosh1

Tokgo: J1teugyō no Whonsha

河竹繁俊監修

298 p.

実莱之旦本社 1957 .

Ed1ted primarily as a compact handbook on kabuki but includes bunraku (puppet play), Japanese dances and muse. Explains basic sage and theatrical termo simply and concisely. Illustrated with many photographs and sketches.

Kabuk1 josatsu

歌舞伎序説 (Introduction to Rabuk1)

Shuzul kenj1

Tokyo: Ra1zōeha

506 p. 111us.

随宽治社 1943.

Asia PL2924.5/.R3S5812

An Introductory text with the blographical section taking up threa-f1fthe of the book. Short blographies of kabukt playrrights, actors, choreographere and pelnters of actors' portralts are given. Th1s work can be considered as a eupplement to Rabulkt zusetsu (Plctorial History of Rabuk1), which the author wrote in collaboration with Aktba Yoshimi. 
KABUKI - GENERAL

Rabuk1 jöshtk1 butal sushū

歌舞伎定式舞台目集

(Album of Typical Rabuk1 Stages)

Tanake Ryö

1958.

358 p. 111 lus.

As 1. PN2924.5/.R3T35

The author, an expert on theater stages, describes 153 kabuk1

stages with the we of color sketches. Provides the names of typical stages, distinguishing features, stage settings, etc. A valuable reference for ataging kabuki plays.

Rabuk1 jūhachtban 歌舞伎十八番

(collection of Elghteen Kabuki Plays)

Tolta Yasuj1 $p$ 板廉 $=$

Tokyo: Chüb Rorronsha 中央公論社 1969.

224 p. 11lus.

Asia PMR927/.T62

Introduces and explains kabuk1 tühachiban. Traces the Ichikawe Fantly genealogy and describes the personalities and performances of the different actors who assumed the name of Ichiknwa Danfürō. Presents simple explanations of the ecripts, charecters, plots, etc. of the collection of elghteen plays made famous by the Ichikawe Fantly.

Kabuk1 jưhach1ban: kenkyū to sakuhin

歌舞伎十八番一研究と作品 (E1ghteen Rabuk1 Plays: Study and Works) Rawatake Sh1getorh1 河竹繁俊 Tokyo: Hoklkoluha 曹国社 1944. 431 p.

Ala PL767/.K38

Introduces and discueses kabukt fühachtben of the Ichlkawa Danjurō Ranlly. In the flrat half of the book, the "Research" "sectlon, brlef Interpretative coments are given on all elghteen playe. In the second helf, the "Works" sect1on, scrlpts of well-known acts from the followlag seven plays are presented: Ranilnchö (The Subscr1pt1on L1st), Kenuki (The Whisker Tweesers), larukent (Thunder God), Kagektyo, Ia no ne (The Arrow Maker), Sukeroluu and Shlbaraku (Wait Hownt).

Rabuk1 katka 歌舞伎開花

(Flowering of Rabulet)

Suwa Baruo 䚺訲春雄 Tokyo: Kadokeme Shoten 角 III毒店 1970. 146 p. 111us. Asta FO X PA2924.5/.X3S8 
TABUXI - GENERAL

Introduces through large color prints, the development of kabuk1 from 1ts or $1 g 1 n$ as a religlous dance performed by Okunl to full-cale stage plays of the Genroku period (1688-1704). Containe 91 printe, each with detalled explanations given frou the standpoint of kabuk1 Insiders. An English Index of 11lustrations is Included at the end.

Kabuk1 kanshö nyrinon 歌舞伎鑑賞入阴

(Guide to Appreciation of Rabuk1)

Bd. by Tolte Yasuj1

Tokyo: Sōgensha

306 p. 111us.

$$
\text { 涂交社 } 1978 \text {. 編 }
$$

As 1* PN2924.5/. 331233

A beginner' handbook to understanding the basics of kabuk1 plays and appreclation of their distinguishing features. Articles were written by various drama critics and drameturglsts and organized Into three sections: overview of the history and maning of kabukt, Introduction of actors and stage hands, and presentation of kabukl glossary and Interpretations of famous plays.

Rabuk1 kenkgī

(Study of Rabuk1)

Míyake Shütaró

Tokyo: Takananshe

504 p.
歌舞伎研究

$$
\text { 三拓它韩态郎 } 1942 \text { 。 }
$$

As 1a PN2924.5/.R345

Analyzes and Interprets a number of kabukl masterpleces which evolved from 10rurf plays. Complles the results of the author's resenrch, spanning about thirty years, from early Talsho to midShōwa period. Serves as a valuable reference for in-depth scudy of kabukt.

Rabuk1 kenkyü (Kabulk1 Stud1es) Tokyo: Rabuk1 Shuppambu 5 v.
歌舞伎研究

$$
\text { 歌舞伎出版部 1926-1928. }
$$

A serles of 30 monthly lasues (bound in 5 volumes), publtibhed betreen June 1926 and lovember 1928, on various anpects of kabuk1, Including 1ts origin and historical development, famous plays and actors, relationships with noh and forurl, etc. Articles were written by noted drame critics and playrights, namely, Tsuboucht Shōyö, Thara Se1seien (Tosh1rō), Rurok1 Kanzō, Atsumf Sa1taro, Kawatake Sh1getosh1, et al. Includes reprints and reproductions of old documents and color prints of kabukt ectors and scenes. 
Kabuk1 kono hyakunen

(One Hundred Years of Rabuk1)

Tolta Yasuj1 户 板 屎

Tokyo: Mainich1 Sh1mbunsha 新 1978 聞社

269 p. 111us.

A concise historical account of kabukl during the hundred years since the start of Meljl period $(1868)$. Includes brief blographical sketches of Shimpa (Now Rabuk1 School) actors, revlews of ShImpe plays of Iruml Kyoke (1873-1939), and commentarles on kabuk1 actors, Ichtmura Uzeemon (1874-1945) and Onoe Klkugoro (1885-1949).

Kabuk1 kumador1 zusetau 歌舞伎险取図説 (Illustrated Explanations of Kabuk1 Make-up) Ueno Tadamasa Tokyo: Shōkokushe 彰国社 1943. 162 p. 111us. As 1a PN2924.5/.K3U56

Depicts 141 types of kumadorl (kabuk1 facial make-up) and explains each type, noting its historlcal and legendary background, as well as its use by prominent actors in certain roles. A handy, practical reference to use when staging kabukt performances.

(Fanous Rabuk1 Plays) Kawatake 8h1getoshl

Tokyo: Zenkoku Jüshō Sh1nsh1n Shōgeí fi(sha) o Mamoru Kat

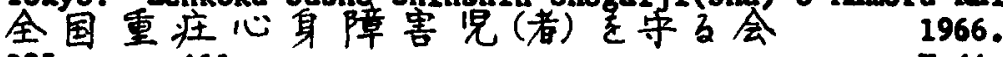
285 p. 111us. Raj1yama

Resembles an album, with numerous photographs, of stage scenes of famous kabukt plays. There are brief explanatory notes on the plots and actors. Includes a short essey by the author on the history of kabukf and comments on the birth of the Mational Theater. Also contalns synopsis of different categorles of kabuk1 pleys Including: kabuk1 tühachlban (alghteen kabukt plays), gldayo kyōgen (18rur1-based playt), kabuk1 buys (dance plays), lun kabuki (pure kabuk1 plays) and hin kabuk1 (new kabuk1 playo). Of practical reference value in staging kabuk1 plays.

187 Rabuk1 meleaku j1ten 歌舞伎名作事典 (Handbook of Famous Rabuk1 Plays) Ranazawa Yesutaka Tokyo: Se1abō 388 p. 青蛙金 1959 .

As Ia PN2924.5/.R3R35 
KABURI - GENERAL

Outlines and explains 400 plays selected from the present-day kabuk1 repertolre. Roviews highlights of the playe. References are lieted at the end of each play. Includes Index of plays, which are arranged in syllablc order, and an appendix containing biographical sketches of famous playwights.

(Chronology of Kabukt)

Bd. by Thara Toshirō, Rawatake Shigetoshı and Yoohida Teruj1 伊原敏郎著，河竹繁俊，吉田暎二編 Tokyo: Iwanamd Shoten 岩波音店 1956-1963.

8 v. 111us. As la Ref, PN2921/. I34

Considered the most comprehensive and authoritative of existing kabuki chronologies. The format consists of two columns, with the upper for plays performed In Bdo and the lower for Kamigata (RyotoOsales areas), to factlitate comparisons. Chronology was arranged on a yearly basis and for Kamlgata, covers the period from 1559 unt11 1907, and for Edo, 1624 to 1895.

(Beauty of Kabuk1)

Noguch 1 Tatsuj1

Tokyo: Kaj1ma Renkyūjo Shuppanka1

201 p. 111us.

歌舞伎の美

$A$ guide to the understanding and appreciation of kabuk1. The or 1 in of kabuk1, types of plays, actors' roles and acting techniques, costumes and make-up, stage settinge and music, etc. are almply explatned to help epectatora senjoy this dramatic and expressive form of theatrical art. Brlef synopels and polnts to observe, with pertinent 1llustrations, are presented for 30-odd famous plays.

rabuk1 no b1galou か、了:‡の美学

(Aasthet 1cs of Rabukt)

Gunj1 Masakatsu

Tolyo: Engek1 Shuppansha

318 p. 11lus.

郡司，正勝 演虡出版社 1963 .

Alla PK2921/.G8

An aesthetical study of kabukt, analyzing its dramatic and musical components, interpreting the ignificance of its acting forms and techniques and theorleing on the roles of good and evil in portraying theatrical beauty. A scholarly and phllosophlcal work on the nature of kabuk1 beauty. 
KABUKI - GENERAL

191 Kabuk1, nō, bunraku: cono atarash11 m1kata 能・文染一染9新しい見方一 (Kabuk1, Loh, Bunraku: Taking a New Look) Bd. by Hamamure Yonezó and Rinoshita dunj1 木下順二 編

Tokyo: Helbonsha 平 凤社 1954 .

327 p. Lllus. Asla PR2921/.836

歌舞伎

浜村米藏

A compllation of analytical essays by several dram experts on various aspecte of the traditional performing arts of kabuk1, noh and bunraku. The focal question of the studies is how to preserve and continue these arts. The present status, opacial characteristics, popularity, etc. of each art are taken up. The appendices Include annotated references, Interpretations of famous plays and a chronology of the performing arte dating back to the year 612.

Kabuk1 no denshō 歌舞伎9伝承 (Transmittal of Rabuk1 Tradition) Suwa Haruo Tokyo: Sonninsha 許人杜 222 p.

1979.

Asia PR2924.5/.R3S82

A collection of essays on kabukt by an author, Surr Baruo (1934-) , who is a reseacher of the playright Chikamatsu Konsaemon (16531725). Essays are divided Into three sections: actors, plays and creativity. Intends to analyze and explain kabuk1 from a modernistic standpoint.

Rabuk1 no füke1 加亦9風景一增榑改訂一 (Observations on Kabukt)

Ragayaun Naozō Tokyo: Shin Dolushosha 349 p. 111us. 加賀山直三 新喷妻社 1978 .

As1a PN2927/. $227 / 1978$

A collection of short articles generally divided Into two parts. The first, titled "5-minute Intermission," contains randon thoughts on kabukt, In general, Including the author's Impresalone of playe and performances, enecdotes and episodes of theatrical porsonalities, etc. The second part 1s devoted to kabuk1 actors of the past and present. Intended as light, entertaining reading w terial.

194 Kabuk1 no genzo (Rabukt Revelations) Hattori Sachio Tokyo: Asukn Shobó 354 p. 111us.

歌舞伎の原像

服部幸婎 聋息豆房 1974 。

Ala Piz924.5/.123588 
RABURI - GENERAI

Analgtical study of kabukt as performed during the Bdo perlod. Considers kabuk1 fros various viewpolnts, such as its bistorical development as compared with puppet plays, the Influence of ectors In changing acting forms, the role of playwights in kabukt growth, etc.

(Thoughts on Rabuk1 Or1gin) Gunj1 Masakatsu 郡司正腃

Tokgo: Mishizawa Shoten 西沃妻店 1978.

333 p.

As 18 PN2924.5/. R3G812

An ethnic and folklorletic study of the concepts and bellef: which led to the birth and growth of kabuki. Analyzes the formation and composition of kabuk1, noting the Influences of moh and jörur1, contributions of famous playwights, etc.

Kabuk1 no inöch1 歌舞伎 91195

(Eseence of Kabuk1)

Rawatake Toeh10 and Yosh1da Chlak1 文\%河竹登志尖写真/吉田千秋 Kyoto: Tankoshe 1969 . 265 p. 111us.

As 1a PL767/. 1034

Through photographle 11lustrations and brief explanations of different stage scenes, attempts to portray the stylized beauty and human expressiveness of the performing art of kabuk1. Various types of themes are selected to cover the wide range of human emotions and characteristics displayed in kabuki, Including shintū-mono (love sulcide plays), 11dal-mono (historical plays), kelselgal-mono (courtesan-buying plays), etc. An entertaining and comprehensive Introduction to kabuki. (Form In Tabukt Acting) Kagayame Naozo Tokyo: Sōgen Shinshn 259 p.

$$
\text { 加賀出直三 }
$$

舦元新社 1968.

As1a PN2924.5/. 2310342

With the ald of photographe, classifies and studies the origin and changes in classical kata (acting form). Explains the various performance atyles and spelfic acting techniques. Dascribes costumes, mke-up, props, etc. needed for the different kata. A worthwile raference to consult in etaging kabukt plays.

Rabuk1 no katsura (Rabuk1 W18s) Matsuda Selfü Tokyo: Engok1 shuppanehe 316 p. $111 \mathrm{les}$.
歌舞伎のかつら

松田青虽

演劇出版社 1959 。 As 1e PH2924.5/.R3MB 
RABURI - GENERAI

As a research reference on wigs, which are important make-up Items In kabuk1, the author, who ts an artist, complled 670 drawings representing 400 types of ulgs. These selections were made from the author's collections of wiga drawn whtle he frequented the kabuk1 theater. A practical reference in learning the art of making wigs and to 1dentify their types, shapes and names.

Rabuk1 no mikata

(How to Appreclate Rabukf)

Kanazawa Yasutaka

Tokyo: Iwasak1 Shoten

281 p. 111us.

歌数伎 の 是。方

金沢康隆 岩 峙妻店 1956.

As 1a GR340/.M575/v.40

A beginner's gulde to kabukt. Explains the history and distinguishing features of kabuki, such as the tradition of kata (acting form), onnagata roles (femsle impersonators), etc. Imparts speclalized Informstion on kumador1 (faclal make-up), backstage activit1es, etc. (Appreciation of Rabuk1: Techniques and Charm) Tobe Ginsaku 争部俆 作

Tokyo: Da11ch1 Hōk1 Shuppan 280 p. 111us. 米一法规出版 1973. As 1a PN2924.5/.K3T62

Alms to Introduce kabuk1 to beginners from the tandpoint of Insiders who plan, choreograph and stage kabukt performances. With the use of many photographic 1llustrations, describes the beauty and charm of kabukt plays, Ignificance of actors' rolea and acting techniques, sultablilty of costumes and stage propa, etc. Contains many hints which will help to increase one's enjoyment of kabuk1.

Kabuki no seka1: kyozō to j1tsusō

(Rabuk1 World: False and True Images)

Karratake Tosh1o

Kyoto: Tankōaha

262 p. 111 us.

歌舞伎の世界一虚像と史像一

Though kabukt is a beautifully artietic and highly stylized form of performing art, it is a reflection of human emotions and living conditions of the times. The author attempts to describe, through analyele of vartous plays, how human feelings and true-to-life human stortes are treated in kabukl. 
KABURI - GENERAL

Rabuk1 no hikaku: Jürokushu no kyögen kanshō o toosh1te 歌舞伎の視角: 十六種の狂言鑑賞走通して (Rabuk1 V1ewpoints) Ragayama Naozö Tokyo: Kadokawa Shoten, 崅岱書店 210 p. 11lus.

1956. As 1a PN2924.5/.R3R243

The author selects 16 works from his kabukf play commentarles published in the theatrical magazine, in Kyoto in the 1950s. Presents his Interpretations and impressions of the plays, particularly the acting forms and techniques and notable roles and performances of outstanding actors.

203

Kabuk1 no shü1 歌舞伎9周用 (Kabuk1 Environment) Tolta Yasuj1 Tokyo: Kadokawa Shoten 戶 板 康二 $280 \mathrm{p}$.

$$
\text { 角川書店 } 1948 \text {. }
$$

As 1a PN2924.5/.K3T643

A collection of brief essays and commentarles on kabukt organized Into the following four aspects: acting form and their importance, actors and their 1dlosyncracles, characteristics of kabuk1 spectators, and Impressions of outstanding kabuk1 plays.

Rabuki no $\operatorname{tanjo}$

(B1rth of Rabuk1)

Ogasawara Yasuko

Tokyo: Me1f1 Shoin

447 p. 111us.

$$
\text { 汃当き9誕生 }
$$

小篮原恭子

明治書院 1972 .

Traces the or $1 g$ In of kabukt, from dances and songs preceding

kabuk1 through onna (women's) kabuk1, waknghü (young men's) kabuk1, etc. to kabuk1 of the Genroku period (1688-1703). Analyzas the Influences of kyögen plays, Imitation art, etc. on kabuk1.

Kabuk1 no zahyō (Place of Rabukt)

Rawatake Toshio Tokyo: Asehl ShImbunsha 230 p.

歌舞伎9座標 河竹盗志夫 每日新聞社 1977 . As 1a PN2924.5/. R3K334

Analyzes the characterlstics of kabuk1 and attempts to define the features that make kabuk1 beaut1ful. Discusses the role of kabuk1 In the modern performing arts. 
KABURI - GENERAI

206

207 Kabuk1 sa1j1k1 歌舞伎歲 時記

Kabuk1 ongaku shüse1: Edo-hen (Compilation of Kabukt Mus 1c: Edo) Inneya Bizaemon 杵屋栄左衛阴 Tokyo: Rabuk1 Ongaku Shüse1 Kankōka1 1976.

543 p. $111 \mathrm{us}$.

歌舞伎音宜集成 刊行会

As 1a PN2924.5/.R3K55

A compllation of music sheets with staff notations and lyrics of kabuk1 geza (off-stage) music which had not been recorded heretofore. Each plece of music is annotated. The music scores had been publiohed between 1967 and 1975 in the Gelnö (Performing Arts), an organ of the Geinō Gakkal (Soclety for the Performing Arts). (Annus1 of Kabuk1 Events)

Tolta Yasuj1

Tokyo: Chise1sha 1958 .

188 p.

As 1a PN2924.5/.R3T63

Climatic, geographical, zoological, botanical and human factors and events, which appear in kabuk1, are discussed in the seasonal order, 1.e., beginning with New Year's and followed by the four seasons of spring, summer, fall and winter. Examples are discussions of the lion dance performed during New Year's, flower-viewing in spring, sumer festivals, chrysanthemums in fall and kabuki plays designed to introduce actors in winter.

Kabuk1 satken

(Kabuk1 Guldebook)

İzuka Tomolch1rō

Tokyo: Dal1ch1 Shobō

1084 p. 11lus.
歌舞伎細見

$$
\begin{aligned}
& \text { 飯塚友一郎 } \\
& \text { 第一曺房 } 1926
\end{aligned}
$$

As 1a PN2924.5/.K3I382

Gives detalled accounts of kabukl plays ataged during the Maffi and Talsho' perlods. To show the evolutionary process of the plays, outlines the oubject materials, original sources, revisions and adaptations, playwrights, first year performed, theaters, actors, etc. of numerous kabuk1 plays. A revised, enlarged edition of the author's, Zabuk1 kyögen galken (A Culdebook to Kabuk1 Plays).

Kabuki sakusha no kenkyũ 歌传伎作者 9 研究

(Research on Kabuk1 Playwights)

Rawatake ShIgetoah1

Tokyo: Tokyodō

571 p.

束京堂 1940. 佁

As 1a PI2924.5/.X3K385 
KABUKI - GENERAL

Focuses on kabukf playwights, who had been placed in underprivileged positions within the kabuki theater, and on their play scripts. Describes the characterlotics of kabuk1 playwrights and the processes Involved in composing the scripts.

210

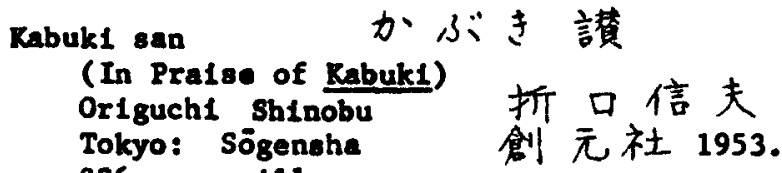

A compliation of Impressions and comments written by the author on modern kabuk1 actors and plays. The basic qualities, beauty and distinguishing characteristics of kabukl are described with sensitivity.

211

Kabuk1 selritsu no kenkyū

歌舞伎成立9研究

(Research on the Origin of Kabukt)

Hatcor1 Yuk10 服部幸雄

Tokyo: Razama Shobo 風間書房 1968 .

596 p. 11lus. Aala PN2924.5/.K3H37

Trles to determine the basic characterlatics of kabuk1 by analyzing Its origin and evolution. Dalves into the precursors of kabuls such as sarugaku (folk music and dance), füryū dance and Okunt's nembutsu odor1 (dance of Amidabutsu), etc. Traces the early typas of kabukt such as onna (women's) kabukl, wakashü (young men's) kabukt and yaro (adult male) kabukt. A scholarly study of the early stages of kabukt.

Kabuk1: shtbal no seka1 歌舞伎一芝居の世界 (Rabuk1: Wor ld of Sh1ba1) ed. by Galnosh1 Renkyuka1 Tokyo: Helbonsha 358 p. 111us. 平 凡社 䒧 能史研 (N1hon no koten geinō, 8

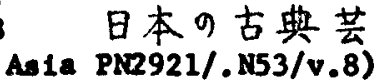

Analyses the essential and traditional qualities of kabuk1. Traces Its hiscorical development with emphasis on the 250 years of the Bdo per1od. Discusses the style and structure of performances, stage and hand props used, muslcal accompaniment and the present status of kabuk1 in the Japanese parforming arta.

213 Rabuk1 sh1mpō (Rabuk1 Masic) Tokgo: Genrokukan Vos. 1- 1600 .
歌舞伎新報

去展瑲 1879-1889。

An1a PN2924.5/.K3K32 
RABUKI - GERERAI

A compilation of brief periodicals called the Kabukt ahimpo (Kabuk1 News), published between February 1869 and Karch 1879. contalning new about ksbule1 plays, ectors, etc. Considered to be an Indispensable source material on theatrical arts of the Malj1 period.

Rabuk1 sobyö (Kabuk1 Sketches) KInoshita Shüich1 Tokyo: Rödansha 96 p. 111us.
歌舞传素描

$$
\text { 木下秀一 }
$$

As 1a PKR924.5/.K3K57

Contalns sketches of stage scenes of famous kabuk1 actors who are representative of the early Showa perlod.

(Thoughts on Rabukt)

Kawatake ShIgetosh1

Tokyo: Chūō Rōronaha

257 p.

歌舞伎叢 放

A collection of articles from the author's research thesis on kabuk1. Presents historical information on the reform of this theatrical art. Discusaes performing techniques and a fer famous playe.

(Collection of Rabuk1 Records)

Ed. by Sasa Maselchi

Tokyo: KInkōdō

540 p. $111 \mathrm{us}$.

中河竹公論衤1949.

As La PN2924.5/.R3K384

Disturbed about the ecattering of old recorde concerning rabukt, the suthor complles a collection of reprints, review and studies of old kabulet practices.

Serves as an orlentation gulde to kabuk1. DLscusses how kabuk1 playe are etaged, the different types of play ecrlpte and actors, behlnd-the-tage happeninge, etc. Buphas 18 placed on how to enjoy watchlng labukt. performances. 
KABUKI - GENERAL

Kabuk1 to bunraku

歌舞伎と文楽

(Kabuk1 and Bunraku)

Oka Onitarō

周鬼太郎

Tokyo: Waseda Bungaku Shuppambu

$438 \mathrm{p}$.

三田文学出版部 1943 .

A collection of 112 articles, selected from among the author's reviews of kabukt and bunraku (puppet theater) plays, published In the Tokyo Asah1 Newspaper from January 1929 unt11 December 1931. Performunces shown during certaln wonths at well-known theatere, such as Kabuk1za, Mo1j1za, Tokyo Theater, Imperial Theater, etc., are also covered.

219 Kabuk1 to jōruri (Kabuk1 and Jorur1)

Kondo Tadayoshl 近蕃 忠義

\section{歌舞伎と淨瑠璃}

Tokyo: Shin Nihon Shuppansha 1977. 353 P. (Rondo Tadayosh1 Nihon bungakuron, 2 近 藤忠義 日本文学論，2)

A serles of essays, generally divided Into three sections: kabukl and törur 1 , trends in modern literature and random thoughts. In "kabult and jörur1," wh1ch comprises the maln part of the book, the author comments on the historical development of kabuk1 and 10ruirt, contributions of playwrights Nambolku, Mokuami and Chikamatsu; etc. In the other two sections, the author analyzes the relationships between literature and theetrical arts, reveals his role in literary activities, etc.

歌等伎読本

(Kabuk1 Reader)

Kawatake Sh1getoohi

Tokyo: Shüdōeha

254 p.

修道社们繁俊

As 1a PN2924.5/. K3K387

A handbook of kabuk1, comprised of two parts. Background information on kabukt, as form of claselc performing art, ts given in the first part. Representative plays are taken up in the second part, wth 1llustrations of stage scenes, plot summaries and discuselon of actors' performances. A glossery is appended.

Rabuk1 tsuikan 歌舞伎通 金監 (Comprehenelve Survey of Rabuk1) Shuzul Renj1 守蓟害治 486 p. 111us.
1942. As 1a PK2924.5/.K3558 
RABURI - GENERAL

A professional treatise reflecting the euthor's expertise on the subject of kabuk1. The work consists of three sections. The first section gives an overall view of the essentlal qualitles, beauty, trends, etc. of kabuk1. The second section deals with dramatic composition and histortcal survey of kabukt. The third section explains the works and lives of kabuk1 actors.

Kabuki yakusha

(Kabukf Actors)

Uno Nobuo

Tokyo: Selabō

299 p.

歌舞伎役者

宇野信夫

青蛙房 1971 。

A serles of articles, consisting mainly of recollectlons by the author of kabukt actors with whom he associated socially and in whom he had personal interests. The maln character discussed 18 Rikugorō VI (1885-1949). Also Includes random thoughts on everyday speech and play dialogs, personal experiences, in visiting theaters, contacts with neighbors, etc.

Rabuk1: yōsh1k1 to denshō

$$
\text { から゙きー样式と伝承 }
$$
(Kabuk1: Pattern and Transmitta1) Gunji Masaleatsu Tokgro: Ne1raku Shobo 害梁書房 1954.

342 P. Lllus. As1a PN2924.5/.R3G85

The author searches for the source and origin of kabukt by ranging widely over the fleld of folk arte. Attempts to Identify the different patterns of kabukt, the1r formation and development from folk arts, and their evolution over the years. (Kabuk1 Misce 1lany) Rawatake Shigetoah1 Tokyo: Robunsha 285 P.

歌舞伎雑記

$$
\text { 光河竹䇣俊 }
$$

As 1a PN2924.5/. $23 \times 38$

Consists of three parts: 1. A series of erticles on varlous aspects of kabuk1, 2. Essays on the relationsh1ps between kabuk1 and bunraku (puppet play), and 3. Compositions in commemoration of decesead writers in the fleld of dramatic ilterature.

1956.

Ao1a PN2924.5/. K3K36 
A 3-volume collection of treatises on kabuki, divided Into editions on kabukt as a performing art, play scripts and actors. Commentarles were written by experts in their reapective fielda. For example, Vol. 1 contains an esaay on the history and characteristics of kabuk1 by Gunj1 Masaketsu, Vol. 2 an article on the history of play scripts by Rawatake ShIgetosh1, and Vol. 3 a treatise on famous actors of Malj1, Talshö and Shöra perlods by Mlyake Saburo.

(Plctorlal Record of Kabuk1)

Ed. by Rawatake Sh1getosh1 and Narasak1 Munesh1ge 河竹繁俊楢崎宗重

Tokyo: Tokyo Chūnich1 Sh1mbun Skuppankyoku 束京中 $\theta$ 新閪出版局 1964.

1 v.

111us.

As 1a FO X PN2924.5/. $\mathrm{K} 3 \mathrm{~K} 3$

A reproduction, In original size and color and In book form, of the Uneme kabuk1 zōsh1 emak1 (Rabuk1 P1cture Scrol1) preserved in the Tokugawa Art Museum of Negoya. A signiflcant record, not only for 1ts artistic value, but for the historlcal information provided on the acting patterns, staging techniques, types of theaters, etc. during the Inttial stages of kabukt as a performing art.

Kabuk1 zusetsu 歌舞伎目説

(Plctorial History of Rabuk1)

Ed. by Shuzul. Renf1 and Ak1ba Yoshim1

秋菜芳美瀷

Tokyo! Man'yokaku

万葉䴙

守随害治

2 v. 11lus.

Composed of two colume with the maln volume containing the plctorlal records and the appendix, the annotations. The history of kabuki, between the Relchö period (1596-1614) and Melfl Restoration (1868), was divided Into four periods and for each perlod, the following types of materlals were complled: kabuk1 11lustrations, theater scenes, playb111s, kyoggen texts, scenarfos, d1alog scripts, jörurl and nagauta standard texts, commentariea on actors, kabuk1 woodblock printe, etc. 

by concise explanetions, attenpts to portray the parsonal charm of actors, dreamlike qualities of playe, artistic use of colors In costumes and stage prope, impressive composition of etage scenery, and the beauty and contraste between motlonlese, suggestive poses and graceful, physical movements.

Gives a detalled description of the 11fe, spanning 77 years, activities and works of the famous playwight, Tawatake Volkusml (1816-1893). Serves also as a chronicle of the theatrical world and the historical backgound of the timas, from late Edo partod to Meljl period. A chronological record of his life activities and wor works, with annotations, is apponded 6

230 Kawatake Koknami Kawatake Sh1getosh1 Tokyo: Shun' yōdō 758. p. 111us.

$$
\begin{gathered}
\text { 河竹黙阿弥 } \\
\text { 河竹繁俊 } \\
\text { 堂陣 }
\end{gathered}
$$

Asia $\mathrm{PL810/.A9253}$

An enlarged, revlsed edition of the book, Rawatake Wokuanl, Which was first published In 1914 and republiohed in 1915 by the Engel Chinsho Kankōkal (Theatrical Bare Books Publishing Soc1ety). Chapter 16, Supplement, which conteins recollectlons of Molvuanl by various theatrical figures, and Chapter 17, Diary, have been newly added.

Kanatake Nokeami Kawatake Shigetooh1 Tokyo: Yosh1kawa Kobunkan 271 p. $111 u s$.

河竹埇阿弥

$$
\text { 河解繁俊文館 1961. }
$$

Based on the author' rescarch of Kawatake Wotuand (1816-1893), the reaults of which were firat published in 1914 and republished in 1915 by the Bngel Chinoho Reaköka1. An enlarged, revised edition was published In 1917 by Shun'yōdō. Research on Holuami continued unt11 1925. This book 1e part of Jimbutsu sobho (Blographleal Serles). of Yoshtkava Köbunkan.

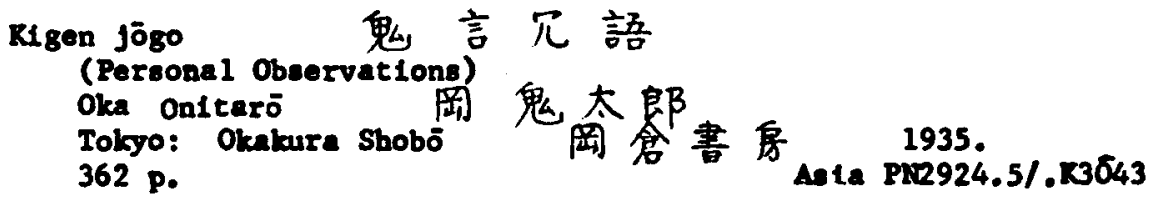


KABURI - GENERAL

The author comments on the performing arts, primarily on kabuk1. and on som cultural aspects. Consists of the following three perte: 1. Gengo füzolu no hanash1 (story of 11ngulstic custons), 2. Gekikn1 uchimaku no hanash1 (behind-the-scene etories of kabuk1 actors), and 3. Shibal katamono no hanash1 (story of kabukt acting patterns).

Kinda1 kabuk1 gekthyōka ron (Analysis of Nodern Rabuk1 Commentators)

Condō Yosh1kazu

Tokyo: Engek1 Shuppanshe

264 p.

蕒㓡出版社 1959.

Traces the history and discusses the nature and purpose of kabuk1 commentaries. Analyzes the reviews of 10 modern kabukt commentators, Including Oka Onitarō, Thara Selselen, Osanal Raoru, et al., of the post-Melfl perlod and polnte out the merits and demerits of each.

Rinse1 engek1 no kenkyü (Stud1es in Modern Theater)

Ta1 Shōnosuke

Tokyo: Ōfüsha

622 p.

$$
\text { 田模相社 } 1972 \text { 助 }
$$

The author belleves that the speclal characteristics of the modern theater are most vividly represented in the plays of the later Edo period. To present his theory concretely, with examples, the author compares the works of the playwights of the later partod, Tsuruya Nambola IV (1755-1829) and Kawatake Noknani (1816-1898) ofth the noted playright of the earlier Bdo perlod, Chikamnteu Yonzaemon (1653-1725). Analyzes the plays of the three forewost kabuk1 playwrighte.

235 Kinsel engekt no kenkyū (Studies in Modern Theater) Takano Masami Tokgo: Tokyods 332 p. 近世演虔 9 研究

$$
\text { 高果予正堂 }
$$

1941. AsLa PN2922/.T55

As source aterials for the study of Chikantsu Monzemon (16531725), retraces and examines the jorurt plays of Inoue Harima-no- $j \delta$ $(1632-1685), U j 1$ Kaga-no-jo $(1635-1711)$ and Tamamoto Kakudaỹ (?-1700). Describes the Interchange and Interacting Influences between tōrurt and kabuk1.

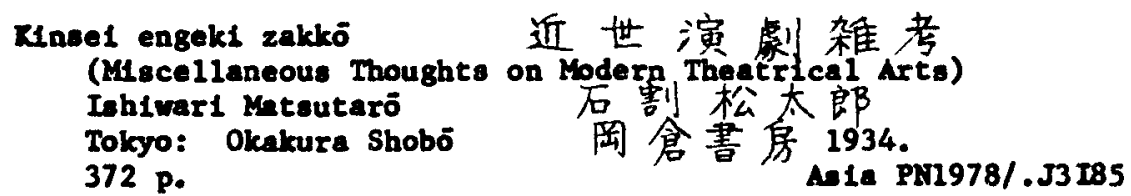


A compllation of essays witten between 1931 and 1933. Begine with studies in ningro 1 orurl (puppet play), examining its besic patterns and techniques, origin of three-men puppet manipulation, typas of puppets, famous puppeteers, etc. Proceeds to discussion of kabuki adaptations of puppet plays. Concludes with miscellaneous observations on initial uses of illuminated stages for dancing performences and the program for the first showing of a Shakespearean play in Japan.

237 Rinse1 gikyoku kenkyu 近世虚伐曲研究 (Studies in Pre-Hodern Drama)

Shuzui Ronji

Tokyo: Chükōkan

235 p. 11lus.

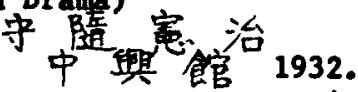

As 1a $\mathrm{PL737/.588}$

A complation of 20 treatises and 4 chronological listings concerning kabuk1 published by the author in periodicals between 1924 and 1931. Treatises include the origin of kabuk1 plays, characteristics of kabuki in Ramigata (Kyoto-0saka area), distinguishing festures of scripts by noted playwights, Sakata Tojūró (1647-1709), Ch1kamatsu Monzaemon (1653-1725), Namiki Shozo (1730-1773), et al. Chronological listings include Namiki Shōzō's plays, dates performed, theaters, etc. (Origin of Pre-Hodern Japanese Drama) Harada Kyötchi Tokyo: Shibundo

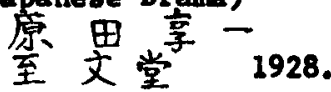
436 p. 近世日本の演劇の源流 A treatise on Okun1 kabuk1, the precursor of modern kabuk1. Traces the evolution of ancient dranatic arte, euch as glgaku, which eventually led to the origin and development of a performing art, kabukt, for the common people. Discusses in detali the beginninge and growth of Okunt kabukt and 1 ts influences on the subsequent development of theatrical arte.

Comprised of three sections: 1. Bxplenations by Fujlnaml Tobel III (1891-1952) on kabuki hand props, doscribing their historical background, types, materials and techniques used in makins them, etc., 2. Glossary of hand props and 3. Bacollections of Pujinami Yohel III by varlous theatrical figures and acqualntances. 


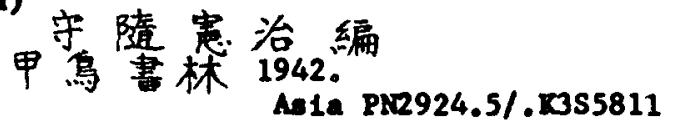

As1a PR2924.5/.R3S5811

A compllation of seven research essays by members of the T\&dal Kabuk1 Kenkgivici (Tokyo Univeraity Kabuk1 Study Group) which was established in 1938 for the purpose of conducting researches on kabukt and traditional drame. Includes essaye by the editor, Shuzul Kenf1 on "The Stage Structure of Puppet Playa," Akita" Yosh10'a, "Rabuk1 Language in Edo during the Genroleu Per1od," etc. Based on scholerly research and useful as a reference text.

241 Rokuritsu Gek1jo kabuk1 kōen (National Theater Rabuk1 Performances)
Koluritsu Gekijö

Tokyo: 19--

Kos. 30-49 (Jan. 1970-Apr. 1972), 57-59 (Apr. 1973-June 1973)

A compllation of printed program sheets for kabuk1 performances held at the National Thester. Contalns a listing of roles and actors and synopses of plays for the particular performance. Also Includes 11 lustrated articles of general interest to kabuk1goers.

Kokur1tsu Gek1jō kabuk1 kōen jōen da1hon 国立劇場歌舞伎公演上演台本 (Stage Scripts of National Theater Kabuki Performances) Kokuritsu Gekijo 国. 站劇場 Tokyo: 19-1970-1976 (scattered issues) Asia PN2924.5/.1337641

A compilation of stage scripts, In mimeographed form, of kabuk1 plays performed at the National Theater. Bach lssue of the script has distinctive title page noting the name of the play, playitight(s), choreographer(s), number of acts and scenes; etc.

243 Ronnich1 no kabuk1 (Present-Day Kabuk1) Tolta Yasuj1 Tokyo: Sogensha 241 p. 11lus.

$$
\begin{aligned}
& \text { 今日9歌舞伎 } \\
& \text { 户刢元康社 } 1952 \text {. } \\
& \text { Ala PN2924.5/.K3T642 }
\end{aligned}
$$

A compllation of 43 short reviews on post-World War II kabuki performances staged in the Tokyo area, between Kay 1945 and December 1951. first at Tokyo Theater and at Kij1za. Popular actors and plays revlewed Include Onoe Shöroku In Truchlgumo (The Wonstrous Spider), Ich1kawe Ebizō in Yowa nasake ukine no yokogugh1 (Scarred Yosaburō), etc. 
KABUKI - GENERAI

244

245

246
Rumador1：kabuk1 no melkuappu 隈取少：歌舞伎のメークアップ (Kumador 1: Make-up for Rabuk1) Morita Jüsh1rō and Bandō Mesugoró Tokyo: Haga Shoten 方贺霄店 253 p. 111 us.
森田拾史郎·军真 坂東三津五郎·文 1969.
As1a PN2924.5/. $33 \times 68$

Primarily an album of photos, in both color and black-and-chite, of different types of kumadori (faclal make-up) used in kabult. Explanations in Japanese, and also in English, of the meaning of the make-up colors, symbolic variations for different roles, etc. are given at the end of the album.

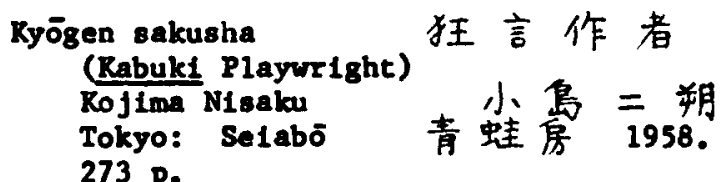

As 1. $22737 / .1264$

An autoblography of a kabuk1 playwright, Kojima Nisaku (1901-), who was a member of kabuk1 theaters. Koj1ma left the kabuki profession in 1932 to devote his career to the Nihon Buyō Kyokal (Japan Dance Assoctation). Five new dance scenarlos created by the author are included.

$$
\begin{aligned}
& \text { Kyöraku butal fudok1 京洛舞台風土言已 } \\
& \text { (Ryoto Localities Seen on Stage) } \\
& \text { Toita Yasuji F板康二 } \\
& \text { Kyoto: Shinshindö 駸堂 } 1923 .
\end{aligned}
$$

The author visits, with the fresh curiosity of a stranger, various localities in kyoto which appear in kabuki and other etage performances. Records randomly thoughts and Impressions which come to his mind as he enjoys the local color.

$$
\begin{aligned}
& \text { Meij1 engekish1 明治演虔史 } \\
& \text { (Theatrical History of the Maijl Period) } \\
& \text { Thara Tosh1rō 伊原敏郎 } \\
& \text { Tokyo: Waseda Dalgaku Shuppambu 早稻田大学出版部 }
\end{aligned}
$$$$
841 \text { p. } 111 u \text {. }
$$

Records kabukt history of the Meljt period, opeciftcally from 1868 to 1903. A sequel to the author's Mhon engekishi (RAttory of Japanese Theater) and Kinsel Khon ensekight (Pre-Modern History of Japanese Theater). These three books cover pertod of 350 year: of kabukt history. This work consiats of an introduction and four sections with emphasis on actors. The introduction and Part 1 , 1868-1878, discusses the establishment of new theatere in Tokyo and roles of Ich1kewe Danjüró IX (1838-1903) and Onoe K1kugoro V (1844-1904). Part 2, 1878-1889, takes up the theeter reform movement In Tokgo and Part 3, 1889-1903, concludes with the final daya of Danjürō and rikugorō. Part 4 is devoted to kabuk1 history of Ryoto-Oacka during early keljl period.

$$
-73-
$$


RABURI - GBNERAL

Wij1 engekishi den: Ramgata-hen 明治演劇史伝：上方編 (Historical Racord of Molj1 Period Theater)

Takaye Shln $\quad$ 高 谷伸

Tokgo: Ronsetsusha 建設社 1944 .

259 p.

Al1. PN2928/.T34

By: surveying the performances of famous actors, attempts to trace the history of kabukt movements in Kamigata (Kyoto-Osaka area) during the Meij1 period. Actor discussed Include Ichlkawa Udanj1 I (1843-1916). who was a new rising otar in early Meljl period in Osakn theaters and Nakamura Ganj1rö (1860-1935), who was a representative Kamigata lebuk1 actor from mid-Maij1 through Taishō and Shöwa periods.

Myajime leabuki nendaiki (Miyajima rabuki Chronicle) Susukida Taró and Susukida Ju Tokyo: Rokusho Kankōka1 354 p. 111us.
宫島歌舞伎年代記

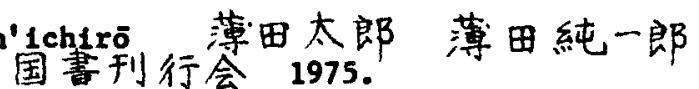
Asia PN2926/.M5S9/1975

A collection of playb111s, for the period 1811 to 1892, of atage performances, primarlly kabuki, held in Miyajima of former Aki province (present ly Hiroshime prefecture). Playbills are printed in reduced size. Contents are also shown in block printing. Appendices contain detalled indexes of actors, plays, etc. and articles on the origin and revival of Hiroshima kabuki.

(Letters, Diar1es, Handb111s,

黑阿弥の手紙日記報條なと” Bd. by Kawatake Shigetoshi

Tokyo: Engek1 Shuppanshe

329 p. 11lus. Btc. of Molougm1)

Reprints of letters, diaries, handbills, programs, etc., in block printing, of the celebrated kabuki playwright, Kawatake Kokuaml (1816-1893). Photographic reproductions of some of the original Items are also included. Explanatory comments are provided by the editor, Kawatake Shigetoshi, a descendant of Kokuani.

Mokuami to Nambolu

(Mokuami and Nambola)

Rawatake Shigetoshi

Tokyo: Ōkōch1 Shoten

327 p. 11lus.
黑阿弥と南北

河竹繁俊 大河内書店 1948 . Asia FL810/.A9251

Relates the 11ves, works and personalities of the two leading kabuk1 playrights, Kawatake Kokuami (1816-1893) and Tsuruya Nambolas IV (1755-1829). Useful as a beginner's text for the study of Edo period kabukt playrights. An abbreviated chronology of aigniflcant events related to the lives of the playritights $1 \mathrm{~s}$ appended. 
KABUKI - GENERAL

Nihon ge1jutsushi kenkyū: kabuk1 to ayatsuri fōryri

日本

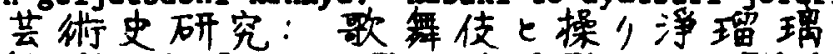

(Studies In Japanese Theatrical History: Kabuk1 and Puppetry)

Hatsuj1 Tetsurō

Tokyo: Iwanami Shoten 岩波害店 1971.

695 p.

As 1a PN2924.5/.K3W4/1971

Analyzee and reveals, in detail, the or 1 in and development of ayatsuri Jorur1 (puppet play) and kabuki. Discourses on the competition and interchange between aratsur1 1ōrur1 and kabuk1. Showe the influence of forurt playe and famoue playwrights, namely, Takemoto Gidayū (1651-1714) and Ch1kamatsu Monzaemon (1653-1724), on the structure and composition of kabuk1 playe and performances. Tries to determine the historical qualities that make kabuki such a unique and exotic performing art.

Nihon shomin bunka shiryō hȳee1, da1 6-kan, kabyk1 鹿文化史料集成 第六卷歌舞伎

(Collection of Materials on Japanese Popular Cylture, Vol. 6, Kabuk1) Ed. by Gelnōehi Renkyüke1 Tokyo: San'1ch1 Shobō 芸能史研究会編

943 p. 11lus. 三一妻房 1973 .

As1a PN2920/. N5V6

A comprehenatve collection of source terials on kabukt. Prefaced by explanations as to the origin, types and ignificance of the source materials. Divided into the following sections: theater texts and scrlpts, theaters and pectators, uritings of playwrights, performances and management, and local records. Source materials are generally categorized as documentary, 1llustrated or folklore.

Wō, kabuki e no shōtai (Introduction to Noh and Kabuk1) Horikosh1 Zentaro Tokyo: Tole1 Da1gaku Shuppanke1 214 p. 111us. 能・歌舞伎入9 招待

Interest is heightening recently among university otudents in the Japanese claselc performing arts of noh and kabukt. This work was witten to serve as a suldebook to deepen the appreciation of these theatrical arts. Matsukaze (The Three Sisters of the Seashore) and Kumagal 1 In'ya $^{\prime}$ (Kumagai'. Camp) are taken up as representet ive plays of noh and kabuk1, respectively, and almple, illustrated explanations are given.

Wö kara kabukt e (From Noh to Rabuk1) Shuzu1 Ranj1 Tokyo: Uchida Shoten 89 p.

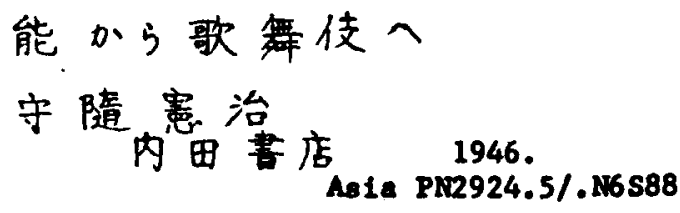

1975.

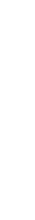


KABUKI - GENERAL

The author asserts that noh was historically considered a performing art for the warrior class while kabuki was for the werchant class but that noh had a strong influence on kabukt. This work chronologically traces the noh Influences during the various developmental stages of kabuk1, from its birth to maturity.

$$
\text { Onnagata no kenkyư 女形 } 9 \text { 石开究 }
$$

(Study of Pema le Impersonator)

Basegawe Yosh10 辰谷川普雄

Tokgo: Ritsumeikan Shuppambu 项命館出版部 1931.

215 p. 111us.

Considers the significance of onnagata (female impersonator), in kabuk1. From the standpoint of kabuki history, discusses the position, life, expressions, attainaents, costumes, etc. of onnagats.

Osaka Furitsu Toshokan-zö shiba1 banzuke mokuroku: Shöwa 43-nen 3-gatsu genza1 大阪府立团妻館蔵芝居番付目录一昭和43年3月现在一 (Theatrical Playbill Catalog in Osaka Prefectural Library as of March 1968)

Osaka Furitsu Toshokan 大阮府立目書飡 Osaka: 1968. $161,20 \mathrm{p}$.

Asia Ref. PR2921/.083

Catalog of playbills $(3,125$ sheets and 2,479 1tems) of kabuk1, which is predominant ningro joruri (puppet play), ehtmpa (modern kabuki drama), etc, deposited in the Osaka Prefectural Library as of March 1968. Playbills of Tokyo, Kyoto and other areas are also included. An index of annotations is appended. Serves as a basic source material for pre-modern theater.

Senryū Edo kabuk1

川朴江户歌舞伎

(Satiric Poems about Edo Kabuk1)

Niahthara Ryrüu

Tokyo: Shun'yodo

再原棑雨

春院堂

1925.

657 p.

A81a PN2924.5/.K3N58

A collection of over 4,000 senryú (satiric poems) concerning kabuki and popular entertainments (aumo, shows, atc.) of the Edo period. Brief explanations are given. Poems are categorized by theaters, famous actors, backstage rooms, etc. and the historical period is given for each. Ilght, entertaining reading materlal but through atiric poetry, the nature of kabuki during the Edo period, reactions of the general populace toward kabulk1, people's customs of the times, etc. can be learned. 
RABUKI - GENERAI (Study of Rabuk1 Domestic Plays) Ed. by Rogek1 Kenkyūka 1 Tokyo: Tengendo Shobs 古㱆研究会編 398 p. 天弦堂書房 1916 。

As La PN2924.5/.R9S48

A compllation of short essays written in early Talsho period by 10 playwights and/or drame critics on seven kabuki domestic plays. Each play 18 commented on by two or more essayists. Playe include Sannin Kichiza kuruwa no hatsugal (The Three Richiza's), by Rawatake Molkuami (1816-1893), Osome Hisamatsu ukina no yomiuri (The Scandal of Osome and Hisamatsu), by Tsuruya Nambolew IV (1755-1829), etc.

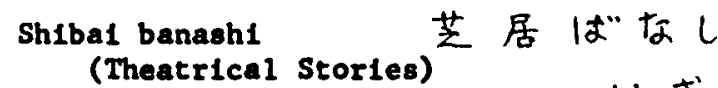
Mitamura Engyo 三田村蓄魯 Tokyo: Kabuk1 Shuppambu歌舞伎出版部 1926-1927. 2 v. illus. As1a/PN2924.5/.1834582 A collection, In two volumes, of short articles delving into the factual background of famous characters and incidents played up in shibal (theatrical plays), predominantly kabuk1 plays, and examines the historical circumstances associated with the plays. Characters and plays discussed 1nclude Oiwa in Yoteuya kaldan (Ghost Story of Yotsuya), Roharu and Jihel in Shintú Ten no Amilima (Love Sulcide at AmljIma), Yosaburo in Yo wa nasake ukina no yokobushi (Scarred Yosaburo), etc.

(Fifty Years of Theatrical History)

Atsumi Seftaró Tokyo: Jif1 Tsūshinshe 時事通信社 1956.

Covers 50 years of theatrical history, mainly that of kabukl, following the deathe of Ichikawa Danjürō (1838-1903), Onoe Kíkugorō (1844-1904) and Ichlkawa Sadanj1 (1842-1904). The three actora, collecively nicknamed Dan-kiku-Sa (from the first character of their first names), had formed a popular trio of a flourlahing period In kabuki history. Th1s work comments on the ups and down of kabuki actors, plays and theaters during the 50 years after Dan-kiku-Sa. 
KABUXI - GELRRAI

A collection of enlightening, entertaining remarks disclosing "Inside" Information on people and things that make up the theatrical world of kabuk1. Organized 1nto the following sections: actors' Images and distinguishing features of their performances; on-stage food, clothing and selter, and the local color of kabuki stage scenes. Filled with amusing bits of observations, such as on actors and acting techniques, Including the art of eating noodles or drinking sake on the stage and how they manage to project the lifellke stage effects.

Shlbal melsho hitomaku mi: butal no ue no Tokyo

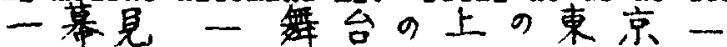

(Glimpses of Pamous Theatrical Sites: On-stage Tokyo)

Tolta Yaauj1 户板 康

Tokyo: Hakusuisha 白木杜 1953 。

169 p. 11lus. Asia PL724/.T65

The author visits and photographs sites associated with theatrical plays, mostly kabuk1, and coments on their past histories, present situation and roles in plays. Sites covered include Sengakuj1 Temple in Takanawa (gravesite of the Loyal Forty-seven Ronin of Chüsh1ngura), former 11censed quarters of Yoshiwara (Scene of Sukeroku), etc. Though photos are outdated (1953), this work serves as an unusual, theatrical guide to famous Tokyo sites.

Shibat no kodogu: 801 to denshō

芝居の小道其一矵意七伝承 (Theater Hand Props: Originality and Tradition) Fujinani Yohe1 Tokyo: Nihon Hōsö Kyöka1 273 p. 111us. Asia PN2087/.J3F8

Explains, In detall, the origin, creation, stage uses, etc. of hand props in theatrical and TV acts. A compilation of articles which were mostly published in the NHK publication, Hōsō bunka (Broadcast Culture). The author is Fujinami Yohe1 IV (1926-). A practical reference to consult for staging kabuki and other theatrical acts.

(The Tro races of Theatrical Plays) M1tamura Engyo 三田村䒫 魚。 Tokyo: Cambunsha 去文社 1920 . 289 p. 111us. Asia PN2924.5/.K3M58

A sequel to the author's Bhtbal to ahifitsu (Theatrical Plays and Historical Facts). As in the previous book, the author investigates the historical truths and circumstances of well-inown characters and incidents appearing in the classic theatrical (kabukt) playo. Plays examined Include Shintū Ten no Amlilima (Love Sulcide at Amfima), Yotsuya kaldan (Chost Story of Yotsuya), etc. 
TABURI - GENERAL

Shibal to shijitsu 芝居と史实

(Theatrical Plays and Historical Facte)

Mitamura Engyo

Tokyo: Selkyסsha 政教社 1911 。

344 P.

As1a PN2921/.M58

The author, who 18 an authority on the social customs of the Bdo perlod, examines the historical authenticlty of famous incidents and characters in kabuki plays. Serves as historlcal probe into the social backgound of the times. Plays analyzed Include Ragamiyama kokyo no nishikie (Mirror Mountain), Ryokanoko musume D81011 (The Girl at the Dofoji Temple), etc. Th1s work 18 followed up by the author's Shibal no ura omote (The Two Faces of Theatrical Plays).

Shibal to shij1tsu

芝居と史実

(Theatrical Plays and Historical Facts)

Sakamoto Tatsunosuke

Tokyo: Toshסdర

224 p. 111us.

東 照堂 1947 . 辰

Similar in intent to the work with the same title by Mitamura

Engyo. Attempts to reveal the truths or distortions of truths of events and characters featured in theatrical, primarily kabuki

plays. Contains a brief, factual account of Okuni, the originator of kabukt.

Shijitsu yori mita kabuk1 shibal

(Historical View of Kabuk1)

史実より観た歌舞伎芝居

MLtamura Engyo

Tokyo: Sübundō

崇文堂村蕉魚

$388 \mathrm{p}$.

As1. PN2924.5/. K3Y581

Views kabuki from a historical standpolnt. Devises to learn about Edo city and conditions of the perlod though the plots, characters, stage settings, etc. of kabuki playe.

Shin kabuki no sufimicht

新歌舞伎9筋道

(Development of New Kabuk1)

Kagayama Naozō

Tokyo: Mokujisha

298 p. 11lus.

加筫山直三

木耳社 1967.

A compllation of a serles of articles, which appeared in the periodical Engektkel (Theater World). from 1966 to 1967, on the development of new kabukt drama after the Nif1 Rastoration. In the prologue, the author briefly explatus the great Influx of European influences which affected even the kabuki thestere in early Keijl era. Blghteen new kabuk1 plays are thea Introduced, 
RABUKI - GENERAL

beginning with Riri hitoha (A Falling Leaf from a Paulownia) by Tsubouch1 Shoyo (1895-1935), with synopses and interpretative comments on the plays. Attempte to trace the origin and evolution of new kabuki through these plays.

270

Zoku kabuki nendatki

続 歌舞伎年代記

(Sequel to Kabuki Chronicle)

Ed. by Hirotani Yütaro

広谷雄太郎編

Tokyo: Hirotan1 Kokusho Kanköka1

広谷国書利行会

1925.

758 p.

Aate PN2924.5/.K3I85

A detalled sequel to Hana no Edo kabuki nendalki (A chronicle of Kabuk1 in Edo). - Covers the period from 1805 to 1859. Containe chronological tables of performances, roles, actors, etc. of kabukt plays ataged in Edo theaters. 
IABUTI ACTONS

275

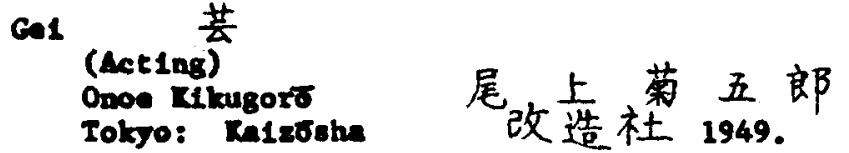

375 P.

As 1a PN2924.5/.R3054

Onoe Klaugoro VI (1885-1949) discloses h1s acting pattern and reveals the ert and ak1ll required in etege performances. Also comente on varlous kebukt plage in which he wes the principal secor. Gel no koloro: kokoro no tatwa
(Eseence of Arts Heart-to-Heart Talks)
Bandó Htsugoró and Ando Touruo 蕉鳥 夫

Tolso:

Whon Seno Shobo

229 p.

111 se.

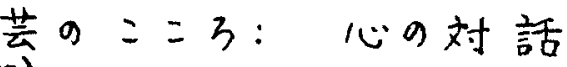

坂東三津五郎，安藤

Becords the Intimate convireations held on December 15, 1968, between Andō Touruo and Bando Mitsugoró (1906-1975), kabulzt actor and founder of the Bando sebool of denelng.

Gosel Ichikawa Denjürs shï: Baluen to Edo bunden

五世市川

団十郎集一白猿七江卢文壇一

(Danjūró Ich1knva $v$ Collectlon: Bakuen and Bdo Itterary World)

Bd. by Hino Tatsuo

Tokyo: Tumani Shobō

日野龍堭编

646 p. 111 us.

中文に熋房 1975 .

A collection of literary uritinge, in calligraphy, by Ichilewe Danjors V (1741-1806) whe was the noet popelar labult ector of the Edo per1od. Upon retiremant from the stage, bo took the pen now of Balwon and vas active in the Tomme (1781-1788) 11terary world as a playright and writer of brolen (eatirical poetry).

Hede jüro yana 秀十郎度言舌

(The story of Hidofürō)

Caira uchio 年谷道雄

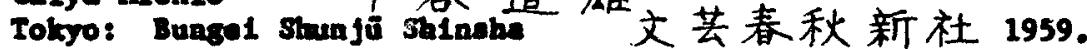
279 p. 111us. Nola M2928/.1394C4

A personal account of likenura kidejür8, tho served for 25

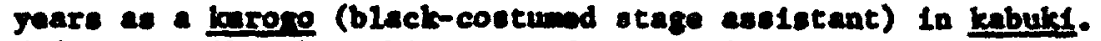
Hidejuro talke about ble art and parsonal exporlences and the book reads like an acoblography. 
raBuIC ACTORS

279

280

281

282

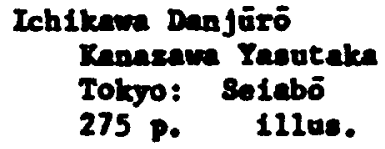

Aale P12927/. TO

A history of Ichikawa Danfürō fally, written in 1962 on the

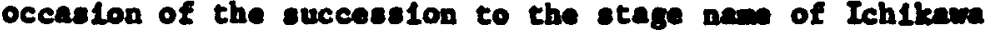
Danjurs XI. The hletory of kabulst can be viewed through the hletory of the Danjüro fantig.

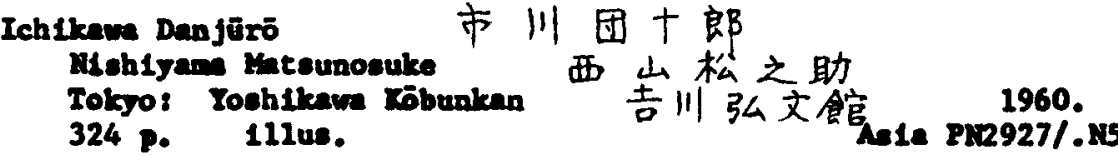

Records the parsonalities, parformances and personnl histories of Ichikara family ambers, from Ichltawa Danjürō I through D. Includes, as appendices, a genoalogical chart and an abbreviated chronicle of the Ichilenu fanily. This work is part of the Ji-buteu atobo (Blographical Series) of the Hhon Rekteht Gaklen (Japan Historical Society).

Ichikave Somgorō

Wiscint Bttoohs

Tolyso: Howf1she

264 p. $111 \mathrm{us}$.

$$
\begin{gathered}
\text { 市川染五郎 } \\
\text { 和角仁 } \\
\text { 木社 }
\end{gathered}
$$

1964. Ale P12928/.W39

Cons1ote of two sections: 1) "Ichikew Somgoro" which recordo the teagnotien, potentialities and thestical experiences of Somagort VII (1942- ); and 2) "Ganealogy of Ichlkava 8owgoro" whtch to a etudy of Someroro I through VI.

Jiden jeppar1 yakusha

(Autoblocraphy, St111 in Actor)

Naknare Tanseburö

Tolso: Bungel Bhunja

229 p. 111 s.

自伝やつぱ役者

中村

文甚春秋

1979. Ante P12928/.1279138

An autoblography of labukt actor, Makamira Innaburö XVII (1909-) ). who saye that if he were robora, be would want to be "otill an actor."

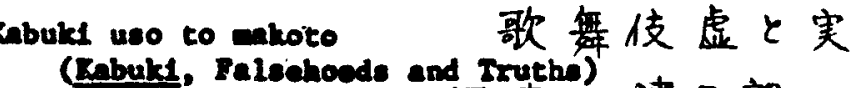
Bando xitaugoro 坂束 三津五郎 Tolso: Tangava Delgaleu shupparbu 1973.

210 p. $111 \mathrm{es}$. 王.川大学出版部

Anda Fr2924.5/..23828 
Bands Mtaugoro (1906-1975), kebuly actor and founder of the Bando School of dencing, reintes his observations and experiences in the thentrical fleld.

Kichiemon alkt (Diary of Klchlemon) Minkenure Kehlewon Tokgo: Ragek1 Shuppansha 407 p.
吉右衛門日記

中村吉右衛䦐

演㓺出版社

As 1a PN2928/. N28

A diary of the period, 1931-1953, kept by Makamura Kichlenon I (1886-1954). Hotates brief1y, in prose and poetry, the h1ghlighte of his dally activities and lepressions. Includes

a chronological record of the vartous roles he parformad as

- kabulas actor.

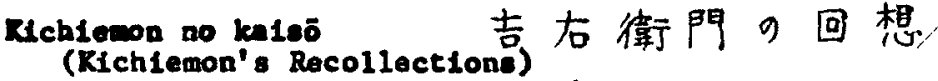

$$
\begin{aligned}
& \text { Chtye uchio 千父道雄 } \\
& \text { Tokyo: Wluj1she 木耳社。1968. } \\
& 318 \text { p. }
\end{aligned}
$$

Decollections of Maknuare Kichlenon I (1886-1954), bened on persond observations during his acting cereer and heareay of his colleagues after his desth. Author wes playright for the Kichiewn troupe and an epprentice of Kichienon.

Thugorō yava (xilugoro story)

Uno Kobus

Tolyo: Sactabō

159 P. 11140.

\section{葋五郎夜話}

宇野信夫

青蛙脣

1976.

Aala PRe928/.05U5

A collection of anecdotee of Once rikugorō VI (1885-1949). Besed on the author's personal observetions and recollectione of those who had been alosely eseoclated with the fawous kabulst actor.

Brüset Danjūrō o lectaru

(Danjüro Dx story)

Tehilewa Sanohō

Kroto: Sulto Shoin

325 p. 111us.
九世団十郎去語る

市 111 三开

1950.

The 11fe experionces, with empheste on etage, of the kebuld actor who represented the Malj1 pariod, Ichileare Danjūrō Lx (1838-1903). 1. told by bis eon. Ichilene Sanohō. Story is replate uth recollections of Danjüro' porformances in the Iühachibea (Bighteen Pawous)playe and anacdotes of his dally life. 
RABURI ACTORS

298

299

300

301

302 Temee mleo 前味唱

Bokudatine Kikugoro

(सtkuger8 VI)

To1te Yeuj1

Tokso: Rngetet shuppenghe

199 p. 11103.
六代目菊五郎

今板康三

演虔出版杜 1956 。

Raj1yama

Belates the theatrical experiences, perticulerly the etage personal1ty of Once Klaugoró VI (1885-1949). Written in informel, eseay-ety le for entertaining reading.

Rolaudate clkugoro hyoden 六代目菊五郎評伝 (Biographical study of ribugorō VI)

Atent Sattero-

Tokgo: Fuzambo

465 p.

111us.

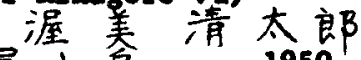

1950.

As1a Pr2928/. 5549

Documente the echlevenonts of the fanous kabukt actor of the Taisht and Shōwa pariods, Onoe KLleugort VI (1885-1949). A detafled "Rikugorō Chronologtcal Table" 1o appended.

Sadanj1 geidan 左団次芸談

(Art Talke by Sadanj1)

Ed. by Taj1m Jun

Tokyo: Maniōoba

274 p.

由息㳯

南光杜 1936 。

An antoblography and a collection of telts about his art by Ichikawa sadanj1 II (1880-1940), who was a ploneer in the modern thenter novement, a well a belos a lenbuls actor.

Shichisel Ichlkawe Bancö (Dansō Ich1trawa VII)

Ich1kewa Dansō

Tohyo: Esūryñdō

400 p. $112 \mathrm{se}$.

$$
\text { 七世市川団藏 }
$$

公龍堂川团藏、

Ala Pl2928/.I28/1966

A collection of art talke of Iehtinum Danō VII (1836-1911). Complled by his successor, Ichlkam Daneó VIII (1882-).

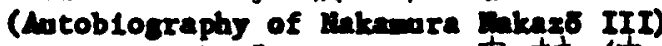

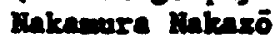

Tokyo: Boklō Shobō

758 p.

地光柿愿 1944 .

Asie Freg28/.1134

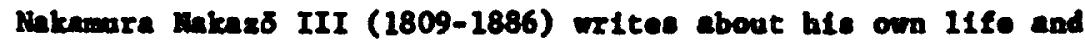
carcer and the hardohipe he encountered as a knbuk1 sctor. His writinge portray vividly the coaditione of the theatrical world as well as the etreet scenes of his tins. 
renuxI scrons

$$
\text { Uzanon deneeter 羽左衛淂伝説 }
$$

(Usecousn Legonde)

Setomi Ion 星見弶

Tokyo: Kalaich1 Shimbunohn 1969 。

224 p.

Aria PL2938/. I3383

Nerrates and analyzes legends portaining to Ichtkawe Useanon XV (1874-1945). First publiched as a sorial in the Matalch1 Shimben.

304

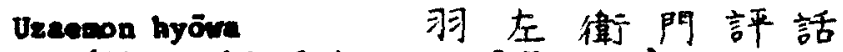

(Blographical Account of Usaemon)

Myales Shütaro

Tokgo: Puzarbs

富宅周太郎

330 p.

As 1a PN2928/ . I33M58

A blographical account of Ichimura Uraenon XV (1874-1985).

Includes Uzaenon's talke about his ow theatrical experiences.

305

Yakuch no selest

(Actor' World)

Raknoura Shtlenku

Tokya: Mlatisha

425 p. 111us.

役者 9世界

中村芝鹤

木耳社 1966 。

Kabukt actor, Makanura Shikaku (1900-), recollecte his stage tralning under the tutelage of predecessors and discusees actint techniques acquired through stage expariences. Introductory section contains color 11 lustrations of kabukf factal make-up, wige, ajobrow and ejelabhes and serves as a pratical reference wha stagline kabukt performances

Yakese shichifünen (Actor for 70 Iane)

Katsolen Nisacimon

Tolsyo: Asaht Shimbunsha

328 p. 111us.

$$
\begin{aligned}
& \text { 役者七十年 } \\
& \text { 片風朝日告新聞社 } 1976 \text { 。 }
\end{aligned}
$$

As autbbiography of Kateole A1zeawon XIII (1903-) whe f1ret appeared on tha lebulet atage in 1905. Written to comamorate 70 rears of actins. Dacollects his stage training and expariences from infancy through tullight jears. A detalied chronicle of stage porformances is appended. 
Akō Gioh1 goktohū 赤穗義士䖉菜

(Selection of Playe about the Loyal Porty-eeven Ronin)

Bd. by Atound Saltarō

Tolyo: Shun'yßdo

725 p. 11lus.

春陽堂美青态

(Hihon gikyota zenshä, 15

日本戲曲全殿，15

Ala PL764/.155/v.15

Salection of seven kabuki playe based on the episode lnvolving Aro Castle warriors, the Loyal Forty-seven rōnin. Play ecripte Include Renadohon Chüchlngure (Twe Treasury of Loyal Retainers), Bhon Chühingura, etc. Preceding each play ecript 1 a a short explanetory note by the editor.

Bakumatsu kyōgenchū

幕末狂 言 集

(Compliation of Late Tolugawa Pertod Plase)

Id. by Ateumi Seftarö

Tokyo: Shun'yodo

春管堂美 1930 .

628 P. 11lue.

(Wihon gikgoku sonohi,

\author{
22
}

日本戯曲全重,22)

Asta PL764/.855/v.22

\begin{abstract}
A compllation of the ecripte of seven kabukl plays by playrights of the late Tolkugaun pariod, notably the works of Salurada Jisuke III (1802-1877). Included to on of Salurade's enserepieces Eiyo Ilneairoku - Doler setdan (based on trial cases of the fasous Magistrate (obke). Containe explanatory comante on the pleye by the editor.
\end{abstract}

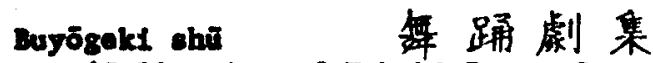

(Collect100 of Iabrik1 Dance Seenes)

Rd. by Ateund seltaró

Tokyo: Shun'sods

春陽堂

清太郎编

756 p. 11lue.

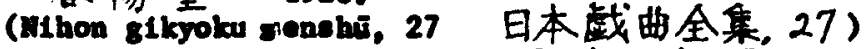

As1a P2764/.855/7.27

A collection of 58 well-knom shossoto (annco-stylo) acts from

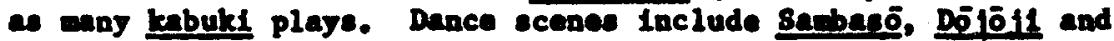
shosaroto of the Atale barrier gate act from Finilech Subscription L1et). Bracading the play script of each scene is - ono-page review by the editor.

Chiknmetou kabuk1 kyōgenohü (Collection of Kibuki Playe Chlkatereu Honsacmon Tokyo: Milkugolinen $2 v$. 111us.

近松歌舞徒汪言集

$$
\text { 六合館 }
$$
Ans 
A collection of 23 kabukt playe by Chikanateu Konsaonon (1653-1725) in two volune. Contain seripts of plays arranged in chronological order. Descriptive coments on the origin of the playe, ectors, performances, etc. precede the ecripts.

(Compilation of Mdd-Edo Feriod Kabult Plays of Bdo)

Bd. by Thara Toshirō

伊原敏期辞

Tolgo: Shun'yods

540 p. 11lus.

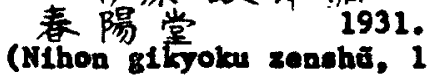

1931.

日本戯曲全集，1） A1a R764/.0155/v.1

A compliation of the ecripte of following five playe: releel rataoksren (1773), Sukerolu kurume no natort gane (1782), Ch17o no hellem Ondo no soto (1785), Saruvelea bandal butal (1786), and Takeo no kye hoe il no kelcho $(1788)$. Apponded are brlef explanatory coments by Thara Sateelen (Toshtro) on each play.

Det Kinbolku zonshü

大南北全集

(Complete Works of the Great Numoku)

Bd. by Taubouch1 Shōyō and Atsunt Seltaro

湟美清太郎编

Tokyo: 'Shun'yödo

春陽 堂

1925-1928.

17 .

Als $\mathrm{RL799/.T88/1925}$

坪内逍遥。

Sectione of lebulet scripts by the great playwight, Touruya Ramboku IV (1755-1829), who wrote actively during the peak of kabulei popularity in the exrly 19th century. This perticular collection consiets of 17 volume and contalns 41 of the nearly 100 pleys Namboka is known to have uritton. Plays include

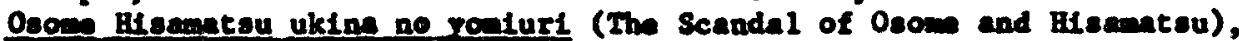
Tokaldo Yoteura kaldan (Grost Story of Yotauya), otc. 1 blographdeal skerch of Iterboka is preuented in Vol. 1.

(Selection of Rlaye about Date Bouge Strife) Bd. by Atsund Soltarö Tokso: Shun'yod 738 p. 111us.

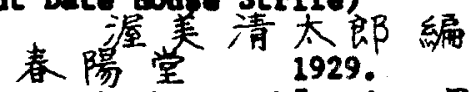
(1929.

日本虐曲全集，16) Ala FL764/. . $155 /$ v. 16

Selection of jorurt-kabulst plays involving the Date etrife (etrife wich occurred in the Bouse of Date, Lord of Sendal Fief, during tho early Bdo priod). Scripte of the playe Include Dace kurabe Olungl kabukt and four others. Ateunt Seltart provides brief background Informetion on the Dete House conflicte and Interpretative comente on each plas at the ead of the book. 
RABURI SCRIPTS

314

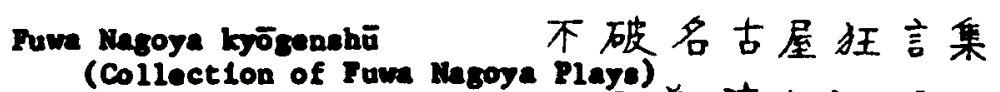

Bd. by Ataund Seftarō

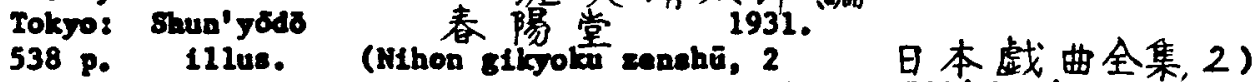

渥美清太郎編

Asta FL764/.555/7.2

A collection of törurt-lebukl play scripte written with liagoya Sanzaburó and Fuwa Bunken ae the pribcipal charactere. Includes three plays: Hilachiyandono kabukino da and Ieleel hane no eavees. Following the scripte exe explanatory comente on Fume llagoya playe by the editor.

Conroku kabuki keseaknehū

元禄歌舞伎傑作集

(Collection of Cenroku Berlod Labukt Materpieces)

Iokgo: Waseda Dalgaku Shuppebu 早稆田大学出版部 1925.

2 v. 11lus. Alia F1767/.T35

A collection of unaltered repeinte of 1llustrated scripts which were oold at every kebukf porformance by the various theaters. Vol. 1 containe 24 scripte of representative plaje staged by the four Bdo theaters durfas the Ganroku period (1688-1703). Vol. 2 contalns 20 scripts of representative lebulet plaje performa at three Iyoto and four Oanke theatera.

(Collection of Ganroku Inbuk1 Ser1pte)

sd. by Yüda Yoahio and Tananachl Tomose

栅田知 弥编

Tokso: Koton Bunko

古典丈席

2 v. 11lue. (Koten bunke, 160, 176
祐田善雄。

1960-1962. 古典文康，160，176) A12 22767/.294

A collection of roprints, In block printing, of the seripte of Centoku Bdo kabulet fron the Alton collection of Cabridge UnIverelty, Bagland, Vol, 1 contaln three playe and Vol. 2, five playe. Thote reproductions of the original texte are appendod. Explanetory comente on the reproduced plaje and other brigen texts in the Aston Collection are also lacleded. (Collection of Bletorical Gidera Plays) Bd. by Atount Seitars Tokyo: Shun' yōdō 
A collection, in two volues, of ecripte of 25 kebuki hietorical playe adapted from puppet playe. Includas Yoshiteune iembonzaloura (The Thousand Cherry Trese of Yoshitann), Ichinotani futabe runkt (Chronicle of the Battle of Ichinotani), etc. The editorial policy was to eelect playe whicb had been performed often and which emphasized acting over gidayũ chanting. In comante at the and of the book, the editor polnts ont the close relationshlps between puppet and kabukt plays and provides background Information on each play ecript. (Collection of Domestic Bd. by Atounl Saltarō Tokyo: Shun' yödo 646 p. 111us. 聝太夫狂言世話物筑 Gidarũ Playe) 春渥美请太郎编 春陽堂 1930 。 (Mihon gikyoku zenehū, 29

日本戯曲全集，29) A.12 R2764/.155/v.29

A collection of kabukt play scripts which had been adapted from puppet playe with oucceseful performances. The editorial pollcy was to select playe which were not initative but showed originality in the adaptatione. Included are 11 plays, including Shlatū Ten Do Aniline (Love Sulcide at Anijima), Leisel hangonko (The Spirit of a Courtean), etc. Editor's comenteries on the plays are appended. (Collection of Ishikawa coenon playe) Tokyo: Shun'yödō 春陽堂 渥美清太郎編 548 p. 11lus. (BLhon gilkyoku zenchū,

Scripts of 4 kabukt playe with the thief, Iohikawa Coomon, the the principal character. Plage are: Klnmen sosen no kirt, Kone Yaneto

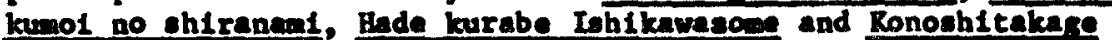
Herame rageen. In the concluding ecetion of the book, Atsual Saitaró relates the history and role of Inhikawa Goomon in puppet and kabukt pleys. (Collection of Pacous rabuk1 Historical Playe) Bd. by Kawatake Shigetosh1, Hamamara Yoneso and Atsuni Seltaro 河竹第俊，洪村来“藏，渥美清太郎編 Tokgo: Shun'yodo 春陽堂 1925. 6 v. 
RABUKI SCRIPTS

A collection, in 6 volume, of the sage scripte of wil-known kabukt historical plays. Companion sertee of the Sewa byogen keseakuaho (Collection of Favou Rabukt Dometlc Plays). Playe Include Ichinotant futabe runki (Chronicle of the Battle of Ichinotani), Releel hangonko (The Sprit of a Courteann), etc. Th1s collection, together with the sewa kyosen ser1es, conetitute a comprehensive coverage of kebukt plaje.

Kabukd Johechtbanshi

歌舞伎十八番集

(Selectlone fron Elghtean Fanous Kabuki Pleye)

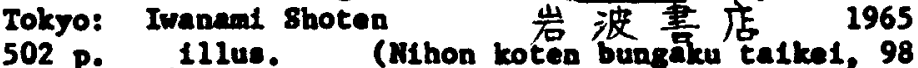
文学大系,981 Asia PL753/.1155/v.98

Presente 7 of the kabuk1 Lühachlban (Elghteen Kabuk1 Plays of Ich1kawa Danjưro fanily), Including Rentinchö (The Subscription List). Sukeroku, Larukand (Thuader Cod), etc. Explanatory comante, koyed to the ecripte, are contalned in the headnotes and staging Instructions are given in the footnotes. Following the scripts are Yaluche benaht or Iakuehe ronge (The Actore' Analecte), consieting of seven exticles, clained to be the wost authoritative discourses on kabukt parformances and the "Bible" for setors. Supplementary references for etaging the seven pleye are appended.

歌舞伎脚本集 (Compilation of Enbuki Scripte) Ed, by Mhon Matcho Zenshí Manköka1 日本名著全集利行会編 Tokyo: 1928. 116 p. 111ue.

(Wthon welcho senshū, 日本名著全菜，8） Asta $2755.35 / .255 / v .8$

A compliation of 12 kebukt play ecripte written by 12 different playwrighte. Scripte are arranged chronologlcally. Besides Culkennteu,

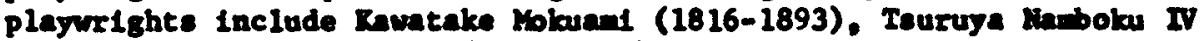
(1755-1829), Anatke Cobel (1747-1808), et el. The Lotroductory eaction contalns explenatory comente on the ecripte, actors, parformances, etc. (Kabukt Rlay Seripts Collection) Tokjo: Iranead Shoten 岩 波萻店 2 v. 111us. (Nihon koten bungala taikel, 53-54 日 本 古典文学大系, 53,54$)$ Asta PL753/.1255/v.53-54 
KABURI SCRIPTS

SLx kabuki play ecripte, one each from six representative playwights, compiled into two volume. Intends to show, through these selections, historical changes in kabukt play scripte, geographical differences and various characteristice of kabuki plays. Vol. 1 contains 3 plays by playurighte of Kyoto-Oeaka area, Chikenateu Konsanon (1653-1725), Nantk1 Shöeo (1730-1773) and Havik1 Cohel (1747-1808), and Vo1. 2, 3 playe by Edo playwrighte, Sakurada Jisuke I (1754-1806), Touruya Nambolu IV (1755-1829) and Kawatake Kokuand (1816-1893).

Rabuk1 kyogenehū (Collection of Rabuki Taxte) Tokyo: Xoten Bunko 255 p. (Koten bunko, 104 古典文庫1956。 古典丈庫，104) As 1a PL736/. 332

A collection of reprinte in block printing, of the texte of $81 x$ kabuki plays of the Genroke period (1688-1704). Plays laclude rana olese fude Wihon hachizo no mine, etc. Bibliographic notes on the six pleye are appended.

(Salection of rabuk1 Minterpieces)

Ed. by Tolta Yasuj1

Tolkyo: Sogensha

釗 元社

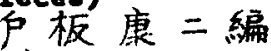

15 v. 111us.

1956-1960.

A collection, In 15 volume, of the stage scripte of kabukt masterpieces by various playurights. Interpretative coments on plays are given at the end of each volume. Vol. 1 starte with Tenedehon Chlahingure (The Loyal Forty-seven Bonin). Vol. 15 contalne the kbuk1 tühachlban (Bightean Kabuk1 Playe) of Ichikawa

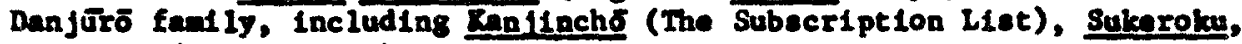
Merukend (Thunder God), atc.

Containe the etage ecripte of Ranjincho (The Subscription List) and five other playe in the in section of the work. Bxplanatory footnotes are included. Following the ecripte are Interpretative comente on the six playe by Tolta Yasuf1. Four short aseage on kabukt characterietice and appreciation, written by rawatake Toshio and three others, are in the concluding eection. 
RABURI SCRIPTS

rangata kyogembon 上方狂言本

(Ryoto-Oeaka Dietrict Rabuk1 Scripts)

Id. by Yüda Yosh10 祐田美雄编

Tokyo: Koten Bunko 古典丈庫 1959-1968.

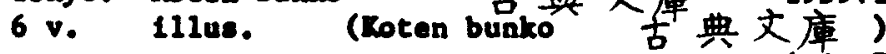

Alia 82766/.235

A collection of reprints, in block printing, of the scripte of kabukt playe rlch in the local color of Engleta (Kyoto-Osaka Dietrict). Photographic reproductions of the original script: and oketches of etage scones are included. Bxplanations of acripta are linited to bibliographic notations.

Kanadehon Chüehingura 仮名手本忠臣藏

(The Loyal Forty-seven Bôn1n)

Fujino Yoshio 藤野 羕, 柇

Tokyo: ofüehn 林根杜 1974-1975。

3 v. L11us.

A descriptive and analytical study, in three volumas, of ranedehon Chühlngure (The Loyal Forty-seven Bonin). A total of 25 scenes from 11 acte are presented in the following order: flret, the play script of a scene, naxt, Interpretations of words and phrases in the ecript, then, the translation into converentional etyle form, followed by historical analyses and explanatione of etage presentations. Blbllographical references, Including pertodicale, are apponded in Vo1. 3.

A compliation of eix leabuki dowatic playe witten and parformad In Edo durtas the ransel pertod (1789-1801). Two of the plays were written by liandict Cohal (1747-1808) who plajed a wajor rois in the developent of dometic playe in Bdo. Commente on the playe by the oditor are apponded.

(Salection of Ravenge Plays of Rathan frea durlng the Ransel Perlod) de. by Atound Saltaro Tokgo: Shun' yōdō 569 p. $111 \mathrm{se}$. 春陽堂 1931 . 
Containe the acripte of three kabukt revenge playe written and parformad in the Rathan (Kyoto-Oanka) area during the knncel Pertod (1789-1801). Plays are Iraroe norlkeke sappe, Katakiucht An'etrolu, and Ane lwoto date no ortdo. Following the ecripte are the aditor': hiatorical andyese and descriptione of the playe.

Selection of the scripts of three kabukt historical plays which were written and performed in the Kelhan (Kyoto-0sake) area during the Kansel Period (1789-1801). Two of tho plays wero written by lantk1 Gobal (1747-1808). Brief Interpretetive coments on the three playe and comparative historical notes on kabukt playe in Rethen and Bdo are includad. Bd. by Ateund Settarö Tokjo: Shun'yödö 渥美清太郎編

716 p. 111 us.

春陽堂堭 1928 。

(Alhon gikgoku zenchü,

A coupliation of seven kabukt dowestc playe written and performad In the Relhen (Kyoto-Osake) area during the late Bdo or the Kancel period (1789-1801). Awons the seven playe 1s Ise onde kol no netabe (Bloodshed at Ine) which ande Chiknantau Tokuso (1751-1810) favous. Historical notes and comente by the editor on the playe are included at the and.

Salection of flve kabult plays, epecielly oritten for keowien (face-shoulng) performances, which rere held from loverber to December during the Edo pariod. Actors were hired on a yearly base during lovenber-December and these performances were intended to Introduce actors of the forthcoming year. The editor's explanation of the keoule playe is given at the beginnins of the book and simple anelytical coments precede aach play script. 
KABURI SCRIPTS

334

335
Kaset-do Edo adaucht kyōgenchū (salection of Devenge Playe of Bd. by Atound Settaro Tokgo: Shun'yōdō

766 p. 111 ins. lays of zdo during the Tnsel Era)
春 陽美 美 清太郎編 化政度江户仇討狂言集 (Mihon gikyolex zenahū, 20

日本戯曲全集，20) AsLa F2764/155/v.20

Complies the scripte of four kbbukt revenge playe during the BunkaBunsel periods (1804-1829). Revenge plays grow auddenly in popularity In Edo during the late Tokugawa perlod and sow of the playe were Imported from Rethan (Kroto-Oeaka) area and revised. Includes the Ehon gapro sa toul1 written by Tauruya Namboku IV (1755-1829). Comants on the plays by the editor are appended.

Kase1- do Bdo sema kyögenshü

化政度江卢世話狂言集 (Selection of Dometic Plays of Edo during the Kneel Bra) Ed. by Atount Seltarō Tokyo: Stun' yödö 642 p. $111 u s$.
春陽堂 1929. 太郎編 (Kthon gikyoku senshü, 18 日本虚戋曲全集, 18) As 1a FL764/.255/v.18

A compllation of seven kebuki domestic plays written and performad In Bdo during the Bunkn-Buncel periods (1804-1829). This is the pertod when domestic playe reachad the height of popalarity in Bdo. Plays by Tauruya Namboku IV (1755-1829) are excluded because thay are compiled in a separate volum. Editor's comente on the plaje are included.

rasei-do rathan adauch1 kyögenshi 化攻度京坂仇討狂言集 (Selection of Ravenge Playe of rathan Area during the Racel Bra). zd. by Atsunt Seltaro Tokyo: Shun'yōdō 春陽堂 1928 。 764 p. 111ue. (Bihon gikyoku senchü.

29 日本戱曲金菒。19) Alle PL764/.A55/v.19

Presents the ecripts of five kabuk1 revenge plays witten and performed In the Tothan (Rpoto-Oaake) area during the Bunka-Bunsel per1ods (1804-1829). Includes the play Bnneahobu uktgt ne Raveren written by Chikenatsu Toluno (1751-1810). Editor's conentaries and chronology of performences are given for each play.

Kawatake Nokuend bü 河竹默阿弥集

(Selection of Playe by Holuent rawateke) Bd. by Kacratake Shigetoshi Tokso: Shun'yōdō 2 v. 111us. 春陭 堂 河竹繁俊 編 (Hihon gikgoku conahū,30-31 日本虚电曲生集, 30-3/) As 1a PL764/.855/v.30-31 
KABURI SCRIFTS

A collection, in two volume, of 16 kabukt playe by the prollele plarmight, Kavatake Nokuani (1816-1893). The f1rst voluw containe 8 playe, lncluding Teuchivumo (The Wontrous Spider), written before the Kajj1 Bestoration of 1868. The second volum aloo contains 8 plays, Including Furikeeen kalke ne funtzukt or Sennin katare (Three Odd Ones). written during the Kifl period and featurins characters wthout the eamural headdrese or zanplrinono. A brief blographical sketch of Nokuent is given in the flret voluma.

Comments on the plays are included. 及竹柴其太集

(Collection of Playe by Shinohichl Rawetake and Kisul Takeabiba) Bd. by Rawatake Shigetogh1 阳 河竹繁俊編 Tokyo: Shun'yods 春陽堂 1929.

722 p. L11us.

A collection of the scripts of seven kabulet plays by Ravatake Shinahich1 III (1842-1901) and seven by Takeahtba Kisul (1847-1923), both disciples of the noted playwright, knwatake Molkuand (1816-1893). Blographleal accounte of the two playwrights and comentaries on the playe are presented by tewatake Shigetosh1.

滑䅦狂言集

(Salection of Comical Labukt Plays)

Bd. by Ateund Seltaró

Tolgyo: Shun'yōdo

810 p. 111us. 春陽堂堂清太

(Wthon gikyolu zenshü, 21

\section{編}

1 日本虚曲全集，21) Asta RL764/.1155/v.21

A coupliation of 12 conical acts taken fron 12 different kabukt plays. An exemple is tho act Chlcht poral from tho play Hanefubult lop no tekerent. Appended are the editor's coments on the role of conical acts in a lengthy lebukf play, and comente on the 12 playe, lncluding the playright, firet performances, actor, etc. (Kuruhon kabukt: Dram and Stage) Bd. by Fujlno Yoshto Tokyo: Sekiguku Shobō 336 p. 111 us.

$$
\text { 丸本歌舞伎一虔戋と舞台 }
$$

A compllation of kabulkt play ecripte based on meruhon (complete 1Brurt texte). Scripte of 11 acte from 9 different playe are preeented

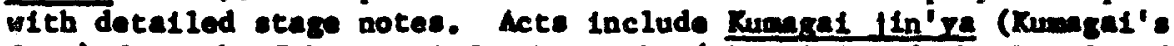
Carp) frow the Ichlmotent futabe gunkt (Chronlcle of the sattle of Ichinotan1), Noselk1-eire (Bosaki V111ago) from Shimban Utazainon (kvo Ballad Singer), etc. After each act are presented background Information, aynopsis and comentaries by lebukt actors. 
A comprehensive collection in 20 volumes, of the ecripte of fanous kabuk1 plays. Amply 11lustrated with photos of etage scenes in the Introductory and textunl sections of each volume. Siaple explanatione precede each play script. The 20 volume are divided: Vol. 1, Chikameteu; Vols. 2-6, 18rurt-based historical playe; Vol. 7, Jorur1-

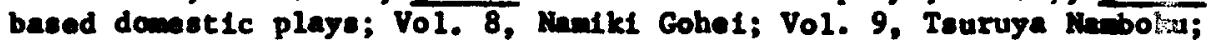
Vols. 10-12, Kawatake Hokuani; Vol. 13, historical plays; Vol. 14, Kyoto-0saka domest lc plays; Vols. 15-17, Edo donoet1c plays; Vol. 18, elghteen playe (Ichlkawa Danfürō); Vol. 19, dance playe and Vol. 20, new kebukt playe.

(Collection of Kokuami Scripta)

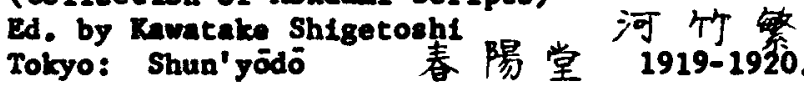
4 v. $111 \mathrm{us}$. Asta PL810/.A9A19

A collection, In four volumes, of 16 knbuk1 play seripte by travatake Kolcuant (1816-1893). Playe include Sannln Kichlea (The Kich1za's). Shirenent gonla otoko (Benten the Thief), ete. PIaye are arranged chronologically and a eimple explanation precedes each script. Performance dates, actors, theaters, etc. for each play are given in the appendix.

Yokuami melsekusen (Selection of Woluand katerpleces) Tokso: Sögenshn 刢 元社 1952-1953. 5 v. 111us.

A collection, In five volumed, of 26 kabukf play scripte by the noted playwrighta, Kawatake Wokumal (1816-1893). Playe Include Gosho no Gorozo (Chivalrous Gorozo) Yakure nasera une no keretobl (Unakichi the Fireman), etc. Interpretative coments are ande on each play by the editor. Xawatake Shigetosh1. A blographic sketch of Mokuni is presented in the firet volume. 
Rovised and enlarged edition of kokuant brekuhonehu (Collection of koluand Scripte). Constets of 27 volunes and the format is generally the eare as h1s preceding 4-volume work. One exception 1. the compllation into one volue of forurt-based playe and kabulet dance plays. There is an Introductory volum which is essentially the blography of Enwatake Nokuand (1816-1893).

Mandk1 Gohe1 j1dal kgogenchū 並木五瓶時代狂言集 (Collection of Hietorical playe by Cohel Naniki) Bd. by Atrund Sa1tarō $\neq$ 渥美清太郎編 Tokyo: Shun'yōdz 春陽堂 1930 。 628 p. (Nihon gikyolu zenahū, 5

Contalne scripte of four kabuk1 historical playe, including Irume kotobe dalmō kateg1, written by Ramik1 Gohel (1747-1808). Brief comente by the edftor precede each play ecript. (Collection of Domestic Rlazo by Gohef Maniki) Bd. by Atsund Seitaró Tolyo: Shun' yodó 776 p. (xihon gikyoku zenshü, 6 春陽堂 1928.

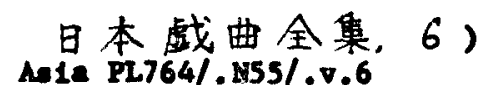
Includes the scripte of elght kabuk1 dowette plays, Including Sunide no heru relohe katert (Bettle of the Geleha), by Namiki Cohe1 (1747-1808). A terse eumary precedes eech play scr1pt. Appended are a blographlcal katch of the author and chronological tables of the performances.

Mintki shōrō shū 並 木 正 三集 (Selection of Shöxö lantkı Plays) Ed. by Atsund Seltaró 春淂堂美清太郎編 Tolyo: Shun'yodö 春陽堂 1929. 780 p. (Mibon gikyoku senabu, 4 日本㠊曲全集，4) A.1. F1764/. $1555 / v .4$

Presente olx plays, celected for their unique fentures, from anons the nearly 10 kabukt plays written by the prolific playwight, rantk1 Shözó (1730-1773). Plays include Relsel ane no haroron and Sanfiklober rofune no halimarl. In the editor' coments, at the end of the book, It is pointed out that Madki was also an architect and 1o credited with the invention of the certese (trap-11ft) and ever1-butal (revolving etage). The sertare was used for the firet tim in the firet play listed above and the mevari-butel in the other. 
KABURI SCRIPTS

01. kyōgenshū お家狂 言菒

(Kabuk1 Playe about the Strife of Fqudal Bouses)

Bd. by Atsual Seltarō Tokyo: Shun' yoodo

560 p. 111ue.

秦陽堂美 等太28。

(Rihon g1kyolu senehü, 24

As 1. PL764/.1055/v.24

Selection of scripte of four plays which belong to the category of olesodomono (Faudal House strife) in forurt-kabukt playe. The central them 1s discord and dissension in the houses of foudal lords which can cause their downfall. The four plays are the yanagi wekrabe no Kagazon (The So-called Yanagisawa House Strifo), written by Maboku IV (1755-1829), Kaleel Bzo nlehtkt (Date House Str1fe), Rol monit1 orure no ehtlieht (Ogura House Strife) and Hanaghobu Sano no yatsuhesh1. Bditor's comente are appended.

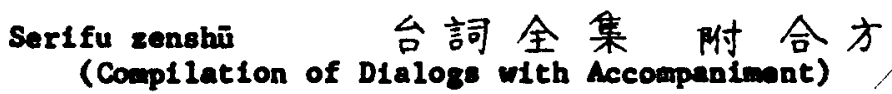

Ed. by Nakauch1 Chōj1 and Tamura Niohto

田村西男編

Tokyo: Nihon Onkyoleu Zonehū Kankōka1

1927.

474 p. (Nihon onkyoku zenshū, 14

中内蝶 $=$

日本音曲全集刑行会

日本音曲全集，14）

Avia M340/.1155/v.14

A compliation of extracts of dialoge from 70 repreaentative ecenes of famous kabukt plays. The dialog extracte contain otaging notes, including ignals for aflete (maical eccompanimat) and narifono (backgound sound effecte). Bxplanatory coments are in the headnotes. Brief interpretative remerk follow each dialog extract. Serves as a practical raference for ataging knbukt parformances.

A collection, in nine volues, of well-known dometic playe, written by playwrighte of distant and recent past, and et111 being parformed today. Presents the play acripte with dialog, ataging instructione, etc., Intended for layman readere. The introductory eectica containe the syopees, Interpretative commate and data on ectore and roles. Playe include Toknido roteurs leselden (Ghost Story of Yotsuya). Iuruwe benghs (Love Letter From the Ilcensed Quarter). otc. 
KABUKI SCRIPIS

351

$$
\begin{gathered}
\text { Shoda1 Sakurada Jisuke she 初优婪田治助集 } \\
\text { (Collection of Jisuke Salourada I) }
\end{gathered}
$$

Ed. by Ataunt Seitaro

Tokyo: Shun'yddo

722 p. 111us.

春陽堂 美清太青太郎編

(Wihon g1kyolu zenoun, 10 日本戱曲全集，10)

As1a PL764/.155/v.10

Selection of seven kabukt play scripte fron the works of 10rurl-kabukt playme 1ght, Sakwrada Jlouke (1754-1806). The ed1tor, Ataun Seltaró, describes Sakurada Jibuke as one of the leading playrights of Bdo and creator of realistic dometle plays. Comentarles on the seven playe are apponded.

Shōsetsu kgakushola kyōgonahū

$$
\text { 小説脚色狂言集 }
$$

(Kabuk1 Plays Besed on Novela)

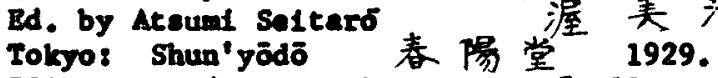

758 p. (Nibon gikyoles zenshü, 25

美清太郎編

1929 .

日本戲曲全集,25)

Ala PL764/.155/v.25

Selection of three famous and Important kabuk1 plays besed on novels: Bane no ent taubont no ratsubues, based on the novel, Hakkenden, by the noted fiction writer Kyokutel Bak1n (1767-1848), Yeemusub Jlralye mporatar 1. adapted from tranelatione of Chinees novele, and Aoto zōghl, Also baeed on a Bakin's novel. Hlstorical relationehtps between novels and play seripts are explained by the adter.

Soga kyögen gappelohi (Collation of Soga Playa)

Bd. by Ataund Seltarō Tokyo: Shun' yödō

812 P. 111 .

春陽堂美清太即㴜

䀦我狂言合併基

(Wihon gikjoku zenshü, 14 日本戱曲全臬，14) An1a FL764/.2555/v.14

A collection of elght representetive plays with the thene of revange by the Sogn brothers. The ecripts of the Sosanono (Soga playe) Include lenrtki redace no sust, Manakusa rosool Soge, etc. Succinct beckgound Informetion on the origla, playrighte, firet performences, actors, etc. of each play 18 given by the oditor in the concluding section.

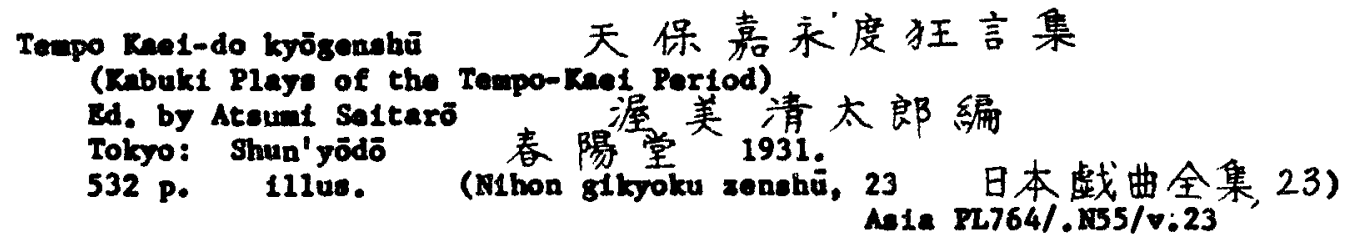


RABURI SCRIPTS

Three kebukt playe written duriag the rompo-inel per1od (1830-1853) when thaatrical art wes at its lowet obb. During such pariode. playrights do not otrive for origlonilty and tond to lmitate and revise exieting ecripte. Playe are Felsel hem no wese, Chirachlrak1 kot no bungho and Yowa nesake ukine no yolrogught (Scarred Yosaburd). Ed1tor's comente follow the scripte. (Collection of Ghost stories by Nanbokn Teuruya) Bd. by Atound Seftarō Tokyo: Shun'yōdó 676 p. 111us.
春
渥美清态
11
日本战曲全集，11)

A collection of the scripts of five knbukt ghost storles by the fanous playuright, Tsuruya Namolu (1755-1829). Includad are the popular playe of Yotauye katdan (Ghost Story of Yotsuya) and Botandoro (The Peony Lantern). A blographical sketch of Manbolat and comentarles on the playe are appended. (Collection of Donestic Playe by Namboly Touruya) Bd. by Ataunt Saltaro Tokyo: Shun' yōdō 726 p. L11us.

猚屋南北世話狂言集

(Hibon gikyoku senohü,

A collection of the ecripte of elx kabukt dometic playe, Includins

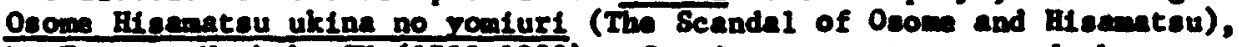
by Touruya Nambola IV (1755-1829). Conc1se comente are made by the editor on each play at the end of the book. (Complete Worke of limboku Touruga) Ed. by Gunj1 Masakatsu Tolsy: San'leht Shobs $12 v$.

$$
\text { 教屋南北全秦 }
$$

$$
\text { 郡司正勝 骫 }
$$$$
\equiv \text { - 费有 } 1971 \text {. }
$$

Alta F799/.T885

Constets of 12 volume and contalne over 60 of the narrly 100 kabukt playe witten by Tauruge Mabolen IV (1755-1829). Basides the play scripte, Includes in each volwe, lueasoht (11lustrated popular etorien) by rimbolew who is credited with over 70 of then.

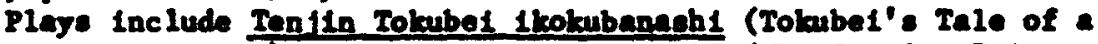
Fore1gn Country), Salurehles Arun bunchō (The scarlet Princese of Edo), etc. At tbe end of each volum are compote and review of the playe. 
NINGYÖ JŌRURI - GENRRAL

An to Awajt no nings shibal

阿波七淡路の人形芝括 (Puppet Show of dre and Amajl)

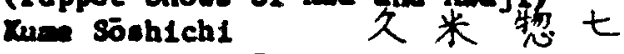
Tokushtas: Krōilu Shuppan Sente 1978.

233 p. 111us.

教育出版七ンタ一

AnL PN1978/.J32784

The author, who 1s a puppet creator, coaplled this work to record for posterity the hietory of puppet show - in Ara and Awajl provinces. Puppet show had reached a retined etate in the Bunralase Theater of Oeakn but retained a rural, folk art flavor In Are and Araj1. Hietorical documenta Inelude "Racord of Puppet Show Performences in Awa and Arajt during the Hijl Perlod," "Puppet Theaters in Are and draji," "Aeraj1 Puppet Theator Inventory." etc.

Ajataurl fōrurt no kenkyū: sono gikyoky kōael ni tgulte

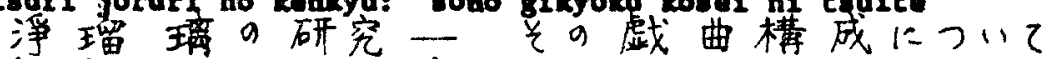
(Studies in Puppet Shows) Chika lobl Yesuakt Tokyo: Lasam Shobo 属間 書房

$1961-1965$. 2 111us. As1. PK1978/.J3C55

Analyees and interprete aratsurl torurl (puppet show) from vertous viewpolnte. A comprehensive work consisting of two lllustrated volunes. Volum 1 covdre three anin eubjects: 1) study of scts and scenes, 2) study of plote and themes, and 3) study of origin and hietorical developent. Volum 2 coverd two ania topics: 1) a theatricel art expreselve of griefs and sorrow, and 2) study of playright, Chticenateu Konseemon (1653-1724).

Ayateurl nings no kno (Puppetry)

Dömoto rensê1

Kyoto: Ichtjo 8hobs

85 p. 111us.

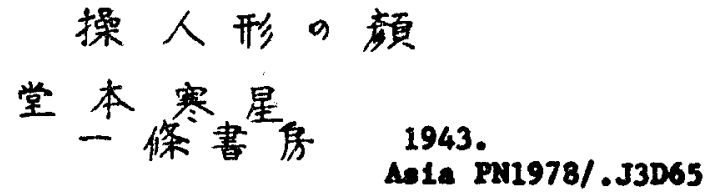

Describes, In general, puppet show as they et111 exiet in the outlying districts. Bxplains the puppet heads of different areas, nasoly, Amj1, Ara and Sedo.

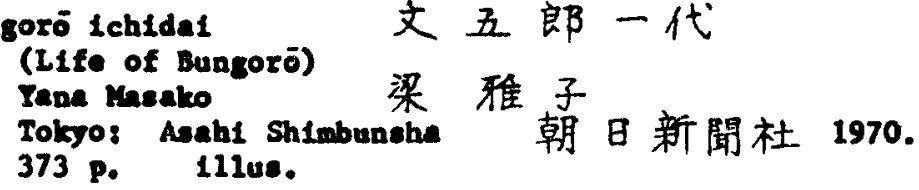

A novel about the I1fe of the anster puppet operator, Yoshida Bungorō (1869-1962). 
MIMGYÕ JŌRURI - GENERAL

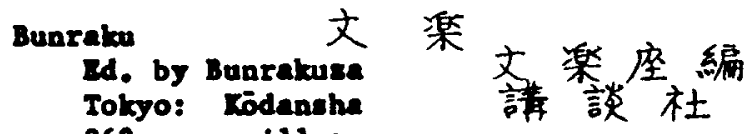

262 p. 111 us.

1959.

Ala $10 \mathrm{PL1981/.885}$

An illustrated text on Bunralu (pappet show), wth descriptione of lts origin and evolution, history, and playwrights and plays produced.

Bunrabu 文 渠

Chaya Banj1rō and Irie Taikich1

Tolyo: Sogranba 剣元社

146 p. 111ue.
茶谷半次郎入江泰吉

1954.

Asia PU1978/.J3C5

Containe 56 pages of photographs illustrating various facete of bunraku (poppet show). The textenel portion includes recollections, art talke and theatrical experiences of contemporary bunralen star: nam 15, puppatears Yoohida Bungorō (1869-1962) and Yoshida Elza (1872-1945), Ehrmisen player Tsurusawa Káno (1879- ?), and L1daru chanter Tojotake Yamehiromo shōjō (1878-1967).

Bunraka - no michi: gono aikata kikikata ajiwaikate 文渠 ก 9 道 (Guide to Bunreku) Makanishi Ka1jirō その芫方・聞きむ・味わい力 中西敬 二 郎 Tokyo: Waseda Daigaku Shupparbu早稻由大学出版部 1975.

276 p. 11108.

Asta PM1978/.J3K34

An orientation guide to bunrala (puppet show) with elmple explanations on the following pints: Lōrur1 (chante), shaplean, puppet operation, puppet beade, puppet types, etc. Containa a chapter on how to look at, listen to and eppreclate bunrake. Apponded are a chart on puppet show chrourhout Japan and a directory of Bunralo-sa performers.

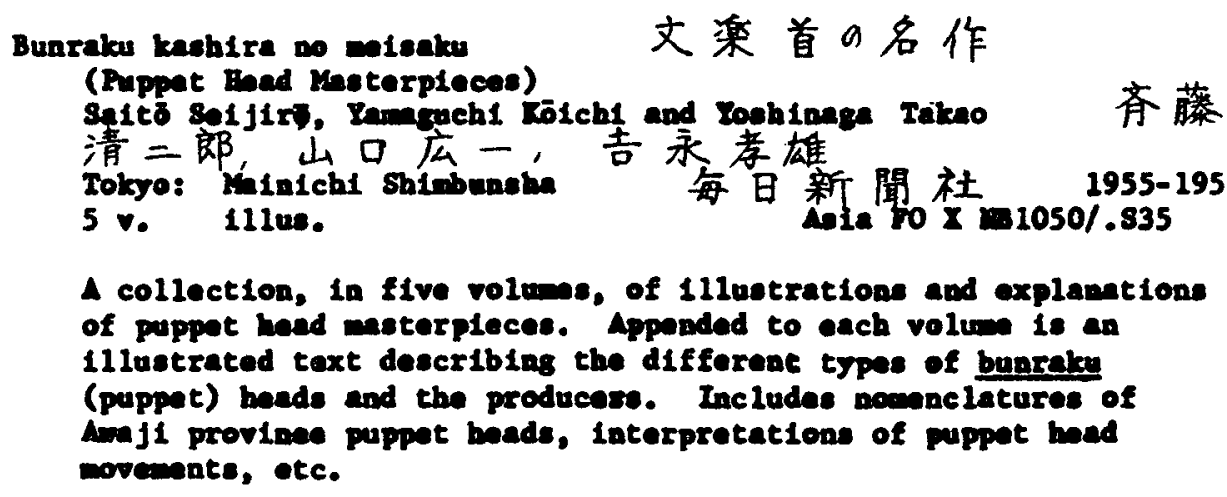

$\Delta$ collection, in five rolume, of 1llustration and explanntion of puppet houd materpleces. Apponded to each volun is an 11lustrated text describing the differanc types of bunreleu (puppet) hosde and the producose. Includes nompelatures of injl provines puppet beade, laterpretations of puppet hese novemente, etc. 
MTMGXঠ JOZURI - GBNERAL

366

367
Bunraku, Kiritako Konjürō

Ando Tauruo and Ranoko Tolsyo: Krūryiēó 371 p. 111ue.
文楽・桐竹紋十郎

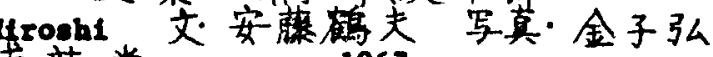
求花堂

1967.

Ala PM1988/.J3A53

A biogrephical account of a fanous puppeteer, Riritale Hoajüro II (1900-). Exphasizes his stage techniques and perfornaces with abuodent use of photo 11lustrations. A detalled chronology of his Iffe and theatrical experiences, between 1900 and 1966. comprises the latter half of thes work.

Buaraku bonjaku nonogatar 1 (Storles of Bunralu. Anctent and Hivderu) Kitand Bogin 木谷蓬 吟 Osalea: Dötombor1 Baklsoje 道頓堀発行所 154, $53 \mathrm{p}$.

Chronteles the history of ningo torurl (puppat show) in a narrative etyle wth ridari chantere, notably Takecoto Gideyr (1651-1714), as the central them. Covere up to date Wij1 perlod, a span of 250 years. Published in comenoration of the opening of the Bunralui-ze theater in Yotsubashi, Osakn in January 1930.

$$
\text { Bunraku: "ningrē no bigaku 文桨：人形 } 9 \text { 美学 }
$$

(Bunxlku: Nawthetics of Puppets)

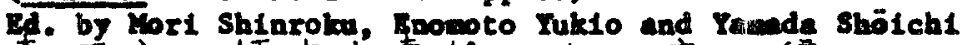
林晋六，䫅本由素雄，山田庄元編

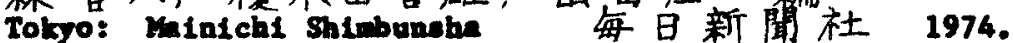

$$
252 \text { p. Lllus. Alis } 10 \times \mathrm{PH1978/.J3834}
$$

Belates, in both Japanese and Engl1sh, the or 1gin, dovelopanat and current status of buareba or alnog 10ruri (poppet show).

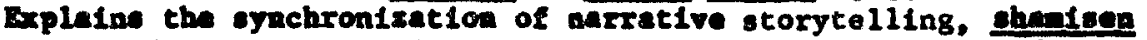
malc and pappet maipulation to ente bunralu a unique porforming art. Deautifully illustrated with 300 color photogrephe of representative playe and puppets.

Bunraku ningrō no anohuten 文染人形の演出 (Performance of Bunralu Puppets) Ondahl Shigetales 大西重孝

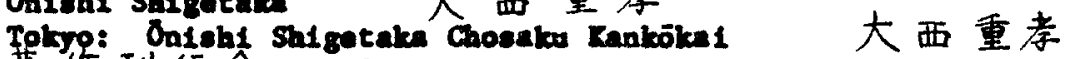
暮作刊行会 1974 。 396 p. 111us. An 2a P21978/.J3055

Posthumous werk of a researcber on bunralu or nlarse lorrurt (poppec show). The firet section deals wth the art telks and stage performances of the fanous pappeteer of the early KaIfi per1od, Ioshide B1Ea I $(1872-1945)$ won the author advitred. The second and concluding section covers the post-World War II history of bunralu. 
MIMET JOTUII - GERERAL

Buraku ningyō sufu 丈桨人形因譜

(Il lustrated landbook of Bunrabu Puppets)

Myeo shigeo 宫尾

Tokgo： Jidalishe 1942 時代杜

412 P. 11lus. Nale PM1978/.J3M:62

Based on sketches by the author, explanations are given of bunralen puppets and thater. subjects covered lacluda: brief history of pupper playe; types of pappote; puppet bads and foet; techniques of handiling the puppets; Interior of the greenroen; hand propa; and bunrelsu argot.

Bunraku no kashira (Puppat Baade)

Ireda Yöko

Tolso: Bage Shoten

260 p. 1110 .

$$
\begin{aligned}
& \text { 丈祭9兮儿5 } \\
& \text { 池由陽子 } \\
& \text { 芳賀書店 } 1974 \text { 。 }
\end{aligned}
$$

Thotographs of puppat heads comprise the firet part of this work wh110 the latter balf consiste of an Interviee by the author with a master puppet creator, $\mathbf{D}$ Minosulse, and essays on puppet hoads.

Bunraku no kenkyō (Study of Bunrelox) Myale Shuterō Tokyo: Shun'yodo 390 p. 11100.

$$
\begin{gathered}
\text { 文楽之研究 } \\
\text { 三宅猿太郎 } \\
\text { 春堂 }
\end{gathered}
$$

1930.

Asia PH1978/.J3M58/1930

A descriptive and andytical introduction to bunralu (puppet show). The first cection describes the origln and wolution of puppots, puppet show and theaters and relates the life ansedotes and thentrical experiences of puppat operators, sideri chanters and shenteen players. The second section presents dron criticlens of plays and conparative studies of plase in Bunralas and pabuls.

373 Bunralku no Elkete 文整 92 かた

(Bow to Appreciate Bunraly)

Wort Shinrolu

Tolyo: ssehtohn

森剌思衣社

1965.

424 P. 1114 .

As1a Rof. PIng78/.J3Ms8

Gives an overall deecription of bunralu (puppet show) to factlitete ite underctendins and apprectation. 


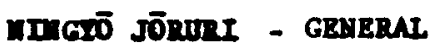

374

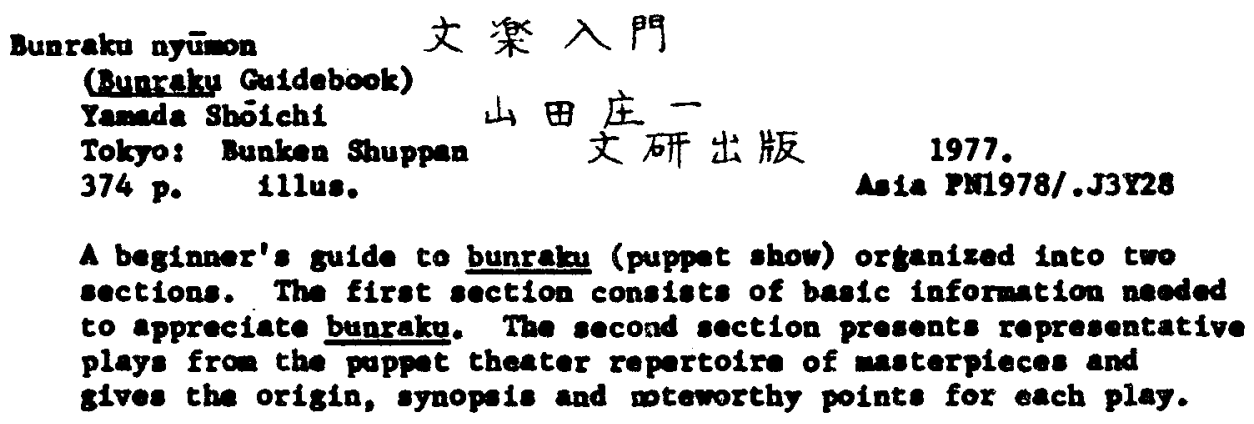

A historical record of alnssō törurt (puppet ahow), beginning with its origin and tracing ite developente until the foration of the Bunrake Xyökel (Bunrake Society).

(HLetory of Bunralur)

Xitani Hogin 采遥吟

Tokyo: Zankokw Shobó 全国書原 1943.

305 p. 11lus.

Anta Pz1978/.J3K5

Rovised edition of Bunraku konialen ponogatari (Stories of Bunralun, Ancient and Kodern). Comprised of three sections: 1) an oponing section which covers the parlod prior to Bunrakuas Theater, from the founding of the Takenotoza Theater by Takeno:o Gidayi (1651-1714) to 1te successful operation, 2) a central eoction which describes the eppearance in Osake of Bunrakuken (1737-1810), foundar of Bunrakuse Theater, and wh1ch relatesu the theatrical renovations of Takemoto Magatodayī (1800-1864) durins the Tompo (1830-1843) perlod, and 3) a concluding section wich records bunreke activities during the 1 liji period. 1956. Aeia PII1978/.J3W34

Alos to explain Anaji puppetry by comparison with bunralu puppetry. Renines the historical developent of pappot playe in Anj 1 and rolationship wth bunraku plays, explaing tho construction and anipalation of puppets, compares the stages and porformances, dafinas the puppetry argot of Amaji, atc. 
NIMGXO JORURI - GENERAI

Bunraku yukahonahü 文臬床本集

(Collection of Jorur1 Texts)

Tokuritau Cekijō

Tokyo: 19--

Scattered 1seues.

As1a PN2924.5/.K3K65

Conetitutes the yukahon (10̄ruri texts) for each bunraku performance staged at the National Thenter in Tokyo.

$$
\text { Ch1kanatsu 近松 }
$$

(Chikanatau)

Bd. by Ökubo Tadakun1

Tokyo: Kadokawa Shoten

国立绪場

460 p. 111us.

(Ranghō Mthon 角们害店 1977 .

大久保忠国編 1977 .

日本古典文学，29)

As 1a PL726.1/. $1333 /$ v.29

Dlscusses four materpieces of Chikamatsu and to orient beginners, presents extrects of the original texts, together with synopese and pertinent explanations, to facilitate understanding and appreciation.

Chikamatou近松

(Chikamateu)

Ed. by Ōkubo Tadakunt

Tokyo: Radokawa Shoten

大久保忠国編

角㺫書店 1957

313 p. (11lus. (Nihon koten kenshō kōxa, 20 日本古典

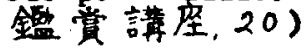

AL1. PL753/.N56/v.20

An explanatory text, on Chikanateu 11terature, intended for studente.

381

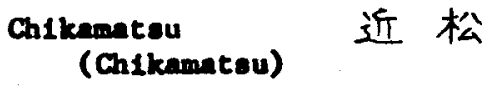

Ed. by Shuzul Kenj1

Tokyo: Sanseids

580 P. (Kokugo kokubungaku kenkgūsht talse1, 10

国入学研究史大成，10)

As 1a PL793.4/.285

Introduces varlous facets of the results of studies on Chikamateu conducted prior to and following the Helj1 perlod.

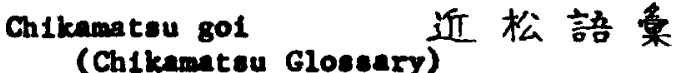

\section{Deda Kannen and Higuchi Yoshichiyo \\ Tokyo: Fueambó 要 山 $\frac{P}{\partial}$}

771 p. $111 \mathrm{us}$.
上田万年，桶口屋千代

Aala Raf. PL798/.C529

Lists words and pharases which are difficult to underatand and makes detalled explanations by giving examples from Chikanatsu'. works and comparing with examples from other worke. An indispensable reference for researcher on jorrur1 (puppetry): 
MmGXō JŌRURI - GENERAL

Chikanatgu josetsul kingel higoki no kenkyō 近松 序説 - 近 悲膚9 研究 (Introduction to chikanetsu)

Birosue Tamoteu

Tokyos Mrelsha

店锌保

438 p.

来社

1963.

Matione the tragle nature of eve-joruri (domet1c puppet plays) by Chibinatsu and discusees his works chronologically.

Chikanates konkyri no joken 近松研究9序篇

(Introduction to Resegrch on Chikumntea)

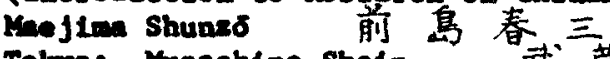

Tokso8 Meashino Sholn ${ }^{\circ}$ 武藏野書院 1925.

305 p.

Ala R2793.4/.25M34

Backeround Informetion necesenty for research on Chikantesu 18 divided into elght categories and explained.

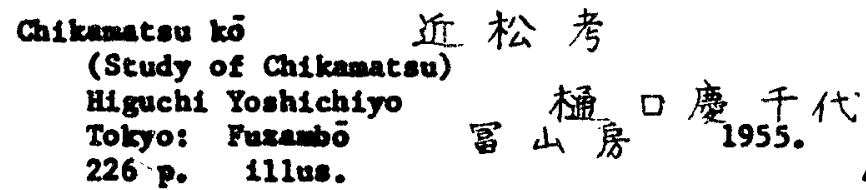

A1a PL793.4/.25H5

Bvaluates aubjectively the works of Chitamenteu and oxpound on the secinl values of his worke.

Chiberateu Monseanon Ravatake Shtgetosht Tolsyo: Toshiken Eobunican 235 p. 111us.

$$
\begin{aligned}
& \text { 近松阴左衛阿 } \\
& \text { 河竹繁俊 } \\
& \text { 吉闹弘文館 }
\end{aligned}
$$

A blography of Chilamesu Konzuemon, Interweaving legende and enecdotes to depiet his life.

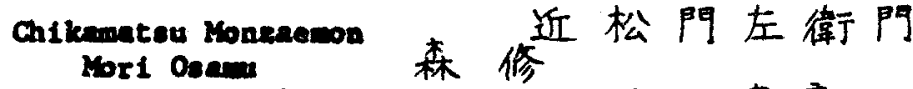

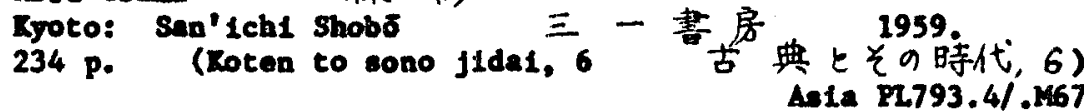

Bramines chronologically, the development of Chikanatsu's sever tōrurt (dometle puppet plays) a traged1es. Aln to idantify the problem areas in the tudy of Chikanateu and to provida leed to future renearch on the fanous playwright. 
NINGTס JŌRURI - GENERAL

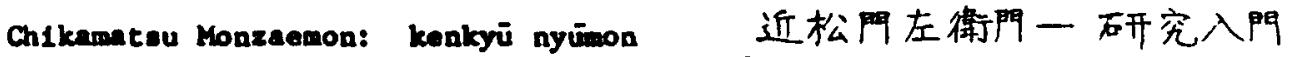
(Ch1kamsteu Monsacmon: Research Guide)

Bd. by Chikamatou Tonkyoika1 近松研究会自属

Tokyo: Tokyo Daigaku Shuppanka1 東京大学出版会 1956. 306 p.

Alia PL793.4\%.25C48

An edited compllation of research papera by members of the Chikamateu Besearch Soclety, which was formed on the occesion of the $300 \mathrm{th}$ birthday anniversary (1952) of Chikamatsu Monzaewon.

A study of Chikamatsu's seva-förurt (domestic puppet plays) which examines the dramatic developent, circumetances, nature, composition, expressions and ignificance of his plays.

Chikanatsu sewa-jōrur1 no kenkyū 近松世話洋瑠璃の研究 (Study of Chikamateu's Domest1c Puppet Plays)

Suwa Haruo 諏訪 春雄

Tokyo: Kesama Shoin 察間書防 1974.

$579^{\circ} \mathrm{P}$.

Asta PL793.4/.25S95

Primarily concerns the study of domestic puppet playe from anong the works of Chlkanateu. The focal point is how his dometic puppet plays or 1ginated and the answer 1s sought in the lafluencing factors of kabuk1 playe which preceeded Chikematsu.

Ch1kanateu to sono dentō geino 近松とそg伀統芸能

(Chikanatsu and the Traditional Arte)

Takano Mneand 高野正 $己$

Tokyo: Kōdansha 1965.

434 p. 111us. Ale Pla793.4/.25T352

An attempt to grasp, through the works of Chikainatsu, the traditione of Jepanese arte that gave birth to kabuk1 and 1ōruri (puppetry). Explores the hietorical elgnificance of Chikantes.

Bdo Bungo jorurt oht (Hietory of Bdo Bungo Jorur1)

Iwase shin' Icht

Tokyo: Kuroshio Shuppan 660 p.

江户曹後弾瑠㻦史

$$
\text { 岩 沙慎々( S. 出版 } 1968 .
$$


NINGȲ JŌRURI - GENERAL

A datalled hiatorical etudy of Edo Bungo 10̄rurl, which was or 1 ginated by Mlyakoj1 Bungo-no-Jö (? - 1740) and which flourtshed in Edo durtng the mid-Edo period.

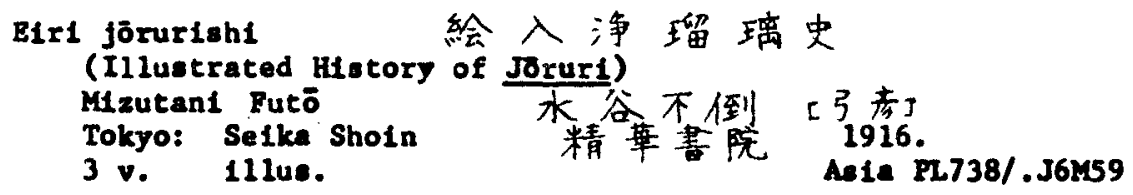

Presents historical and annotative comentaries on approximately 400 origlanl texts of old jorurl (narrative chanta). These texts were selected from among the 11lustrated texts published from early Kan'e1 pertod (1624-1634) to about Cenrolu (1688-1703). Serves to relate historical developmant of old 1ōrur1.

A chronological record of puppet theater performances during the We1j1 period with 11stinge of the benzuke (program with ranking order of perforwers) constituting the in section.

Ito ayataur 1

(Kinrionette)

Yink1 Misgonaburd

Tokyo: Seiabo

323 p. 12lus.
系あやつイ

$$
\begin{aligned}
& \text { 糸城 孫三郎 } \\
& \text { 青蛙房 } 1966 \text { 。 }
\end{aligned}
$$

As Ia FI1978/.J3Y83

Yük1 Magosaburd X (1906-), a anipulator of marlonette (otringa), recollects his childhood and training in the art of marlonette, his sufferings during war time and highlights of his theatrical accouplishente.

Jokyoku no shinkenkyü

$$
\text { 浄曲9新研究 }
$$

(kew Research)

Koyama Tadeshi Nihon Gakujutsu Shinkōika

886 p. 11lus.

日本学術振貫会 1962 . As 1a RL738/.J $6 \longdiv { \hat { a } } 6$

Scud1es tobroku (narrative balleds) frou many angles. Comprieed of section presenting sumery account of jokroku, historical exanination of Idlorolu and essence of joruri (puppetry). 
MIMGX̄ JŌNURI - GENERAL

397

Jōrur1 ayaceur1 ohibai no kanksi:＼cjkstart淨瑠璃操芝居の研究 (studies in Jöruri Tuppetrg)

Tokoyame Tadacht

Tokyo: Rarane Shobo

聩堳要房

1963.

781 p.

Asia F738/.J676

$A$ etudy alood to reveal bow and wen Jōrur' (puppet play chants) took on complicated and moderaistic characterietics.

Jöruri haya gaten

淨瑠璃早含点

(Jörux 1 Simplified)

Ad. by Tor 11 Masenosuks

Oeake: Takentre Kryeouke

$56 \mathrm{pe}$

$$
\text { 莗并正方清助 }
$$

1901.

A beglnner' gulde to 10ruri witten In the distinct calligraphy of jörur1-style scripte and printed on Japanase papar. ithts is the 1901 edition of the text which wa firet pubilshed in 1840.

Jōrur1: katar1 ayateur1 淨瑠璃—語〉操〉—

(Jörur1: Chanting and Puppatry)

Bd. by Gainöshs Lankgüres

Tokyo: Belbonaha 平风社 1975.

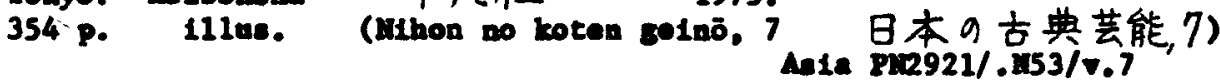

Portrays the fundamntal characteristics of the art of ninged 1ōrurt (puppat plays) by revealins lte hletorical backeround and Ite present etatus. Cownes on the various etyles, techniques, masterpieces, etc. In existence today.

Jōrur1 kenkgū bunken shūee1 淨瑠璃研究文献集成 (Collection of Jōruri Deferences)

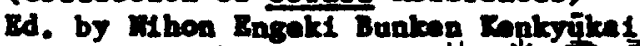
Tokyo: Bokko stobo tt 光音序

日本演㓺丈献研究会编 772 p. 111as. 1944.

A collection of fundenatel texts, with explanations and annotative coments, for the study of lōruri pappet show. Included are Konfelu arateur 1 nendalks (Caronolosy of Rast and

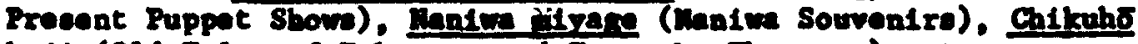
kol1 (Old Tales of Takenoto and Toyotake Thenters), etc.

Jōrux 1 ken'syūisho
(Studies In Jorur1)
KLtan1 bogth.

Tokso:

$295 \mathrm{P}$.
浄瑠璃研究妻

木谷蓬吟素房 
MIRGXত̃ JōmaRI - GENERAL

A compilation of research writings on jöruri (poppot play) chanters, Including Takemoto G1dayū, playwrights, puppet theaters, etc. The appended table gives a chronological eccount of puppet showe from 1811 to 1926. 操 略 史 (Short Hatory of Ruppetry)
Takano Tateuyuks.
Tokyo: Shus' yö́dö

245, $165 \mathrm{p}$.

Historical account of 13rurt (puppetry). A chronological table is appended. Chronologically liets jörur1 performers, titles of puppet ptays, playwrights, puppet show theaters, etc.

Jōrur1 sakusha no kenkgī (Study of Jörurt Playwrights)

Sonoda Tanio Tokyo: Tokyodo $443 \mathrm{p}$.

\section{国昌民雄}

東京堂

浄瑠璃作者9研究
1944.

Ala PL738/.96565

Rophasizes the study of 10rurs playwtights besides Chikamateu Komanon, namly, Kino Kaion, Basegawa Sanohi, Maniki Sōsute, et 1 .

404

$$
\begin{aligned}
& \text { Jōrurioh1 淨瑠璃史 } \\
& \text { (H1etory of Jörur1) } \\
& \text { Iurok1 Ranaó } \\
& \text { Tokyo: Selfiebe } \\
& 581 \text { p. illus. } \\
& \text { 黑木勘蔵 } \\
& \text { 青磁社 }
\end{aligned}
$$


NDNGTÖ JŌRURI - GENERAL

406

407

408
Jörur1 shirōto kōehaku

(Layman Explanat 1ons of Jōrur1)

Sugiyama Rijltsuan

Tokyo: ötor 1 Shuppen

417 p.

$$
\text { 杉山其 日 庵 }
$$

盗出版

D1scusees simply and concretely 84 1ōrur1 (ballad drama) aneterpleces, touching on the moods and thoughts lnvolved in the plays. The author was patron of the förurt circles during ka1j1-Talohó pariods and utilized notes of his talke with the förurl chanters to write this beginner's handbook.

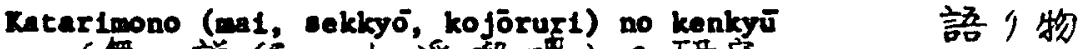
(舞. 説経. 古淨瑠婹) ?研究

(Study of Rerrative' Storytalling: Mal, Sekkȳ, old Jörur1)

Muroki Yatarō

Tokyo: Kazam Shobo 至風間書房 1970.

512 p.

As 1a. R2738/.J6137

Discourses on the processes by which the lowly, popular arts of mal (dance), eakkgo and katarimono (narrative storytelling) of the Middle Ages developed into the föruri of the modern age. Ralates the living conditione and performences of the entertainers of the early period. Chapter 4 discusses in detail, the old foruri lacluding k1mpire torurt which is considered the beginning of modern torurt.

Kinsel engek1 no oh1eō to dentō: j1dal jözuri no kenkȳī 近世 演豦高思想と伝统: 時代浔瑠璃の研究。 (Kodern Theater Thoughte and Tradition)

Ed. by Moriyan Shigeo 㷊山重雄編

Tokyo: Tokyo Toritan Da1saku Dantó Bunka no tri 都立大学伭統文化 9 会 1966. 157 P.

A. ia PU1978/.J3K68

A collection of eseage by elght contributors, Including the author, expounding the theory that in the original texte of historical lörur1 (ballad drama) can be found otrains of eplc pootry which constituted the primordiun of wodern theater.

KInce1 shok1 kokugek1 no kenkyĩ (Study of Plays of Early Yodern Period)

Wakateuk1 Yasuj1

Tokyo: Se1j1sha

$$
\text { 若月保治 }
$$
青磁社

近世初期国剧の研究

$612 \mathrm{p}$.

1944.

Aaia PIR221/.W355 
NINGYŌ JŌRURI - GENERAL

Comprised of Section 1, "Source Materials," and Saction 2, "Rasearch." Section 1 iatroduces reproductions of 19 playe from an old törurt book and from a journal which had been kept by a feudal lord, Mnteudaira Yanato-no-rani. These materials date back to the period, 1655-1680, and some had been hitherto unknown. Section 2 contelas the author's research on Bdo period drame, focusing on törur1. (Bunralou Performances at the Mational Theater) Kokuritau Gokijo 国立劇場 Tokyo: 19 Scattered 1esues.

Constitutes the program for each bunraku (puppet show) performence staged at the Mational Theater in Tokyo. Includes explanatory comente on the playe being performed, background information on the performers, etc.

Nihon no ningoo shibel

日本の人形芝居

(Puppet Shows of Japan)

Tasuda Takeshi

Tokyo: Helbonshe 安田武

$143 \mathrm{po}$ Illus. 平凡社 1976 。

The author, who was charwed by bunraleu puppets, vie1ts Sado, Awaji and otber sites, to view and introduce ningrō shibst (puppet show) which still exist throughout Japan. A pamphlet richly illustrated with color photos.

Nihon no ningyd ahibel

(Puppet Showe of Japan) Nageta Kokich1 Tokyo: Rineelabe 803 p. 11lus.

Through exieting source materials and claselcal literature, Investigates the earlieat usas of dolle in religion, incantation and cultural arts and their relationahipe to the developenent of puppet shows. analyzes concepts and functions associated with dolls and puppets throughout worid. Examines puppetry as a form of performing art and deacribee puppet plays existing in verioue parte of Japan. 
Nihon shoeln bunka shirgō shūsel, da1-7-kan, ningyō jōrur1

日本 蛋民文化史料集成，第七卷，人形洋瑠璃 (Collection of Source Materials on Japanese Plebeian Calture. Vol. 7. Puppet Show)

Bd. by Gainöah1 Kankyilea1 芸能史研究会编

Tokgo: San'1chi Shobō 三-書房 1975.

Ala PN2920/.N5/v.7

A coaprehenelve compilation of cource aterials on ninvo jorurt (puppet show). Prefaced by an outline hiatory of ningo 1 bruri and explanations as to the historical eignificance of the complled materiale. Interpretative annotations accompany the materials which are categorized an follows: general works, art theories, texts for chanting and chanteen playing, puppeteer ratinge and critlclane, stage 1lluetrations and local area recorde.

Ningyogok1 no ceiritsu ni kansuru konkgu

人形虔

成立に開する研究

(Study of Eatablichnent of Puppet Theatere)

Trunoda Ichiró 角田 - 郎

Osaka: Asah1ya Shoten 尤屋書店 1963.

960 p. illus.

Asla Fi1978/.J3T88

Composed of three parte: 1) origin and evolution of puppetry in China, 2) developments in Japan, from the origin of puppetry unt11 immediately prior to establiohment of ningo joruri (puppot show), and 3) developments from the founding of puppet showe until 1658.

(Notee on Ruppet Plays) 仪层秦司

Tokyo: Rinokuniye Shoten 纪伊国屋書店 1968.

191 p. 11lus. Alia PN1972/.K39

Analyaes the origin and historical developante of puppote and puppet playe both in Japan and abroad. Diacusese problea involved in the techniques of puppet oparations and stage performences. 
NINGȲ JŌRURI - GENERAI

416

Mingyō förurich1 kenkgī 人形津瑠璃史研究

(Btetoricel study of Puppet Showe)

Walenteukt Tanuj1

Tokgo: Salmeral shoten 1943.

1175 p.

Traces the rise and decline of nlngrō lörur1 (pupper show) covertas a apan of approxinate 1 y 350 yeare. Racorde the beginninge of puppet andpelations in Bunroles parlod (1592-1595) and follow developants unt11 1942.

M1ngyd jorur1 to bunraku 人形浄瑠璃と文楽

(Puppet Show and Bunralu)

Uteund Shigetarō 海繁太郎

Tolso: Bnkusuleha 6 长社 1958.

Ala PN1978/.J3U882

Racords the origin of ningo shlbal (puppet obow) and traces the developente up to the present Bunrakuza Theater. Focuses on the puppet thater stage and the performance techn1ques, particularis on the conetruction and anipulation of puppet heads.

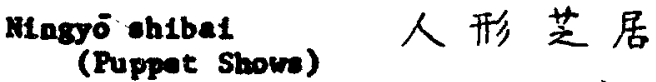

$$
\begin{aligned}
& \text { Ed. by rawatale Toahio 河竹登志夫編 } \\
& \text { Tolyo: Galuget Shorin 学芸音林 } 1976 . \\
& 236 \text { p. 111us. (Dento to genda1, } 5 \text { 伭統と現傅 5) } \\
& \text { A1e Pa1978/.J3138 }
\end{aligned}
$$

A verles of esasse by various suthors on nlavō shibal (puppet show), as thoy extse coday in Japan, frov claselcal bupralu to puppot playe in local-areas. Interview with chneter, Takonoto Wojltegã IX (1924-), ehenteen player, Takexam Danroku (1928-), and puppet operator, Yosh1da Mriosuke (1933-) are Included in an article titlad, "Bow Modern Bunraleu Should Exist."

Mngrö ohibal no kankgü (Study of Iuppat stows) Iohlwarl vetsutaro Oaaka: Shibunkan 315 p. L11us.

$$
\text { 人形芝居 } 9 \text { 石开究 }
$$

厂割松太郎

修文館 1943 .

Asta Pu1978/.J3 I84/1943

Ravised edition of Minrö ehtbal zeteuve (Puppet Show Milecellanies). Atw to expand fundarental understanding and deepon apprectation of puppet show. Explains varioue facete of puppet plays. 
MIMGYō JōRURI - GENERAL

420

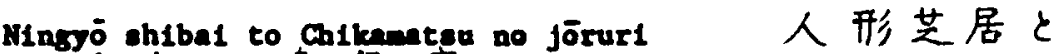

近松 9 净瑠理

(Puppet Showe and Chikenateu's Joruri)

Uteuni ohigoterō

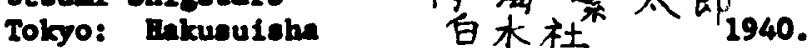

$610 \mathrm{p}$.

Ala PH1978.8/.J3U881

$A$ study of Chikmateu Honsacason (1653-1724) and the playe bo wrote for the puppet theater. Also analyees the puppete, theater stage, production techniques, otc. of Chikanateu's playe to give a better Ineight into the plegwright.

421

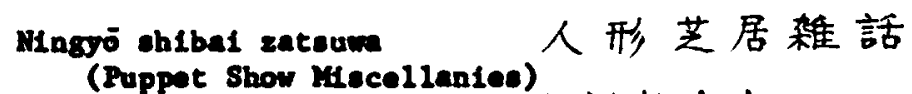

Ishiwarl Mateutaró 原割松太郎

Tokyo: Shun'yōdō 春陽堂 1930.

396 p. 11lus. As1a PII978/.J31852

Presents explanations and interpretations to deepen one'a bavic understending of ningrō shibel (puppet show). Includes eseaje on how to read the progrem listinge, puppetry customs, traluing of puppet operators, creation and minipulation of puppete, etc.

Sonryī jōruriehi 川柳淨瑠璃志

(Book of Jörur1 in Satiric Pootry)

omera shake 大村沙華

Tokyo: Yikō shobō 有光書房 1968.

253 p. 111us. Alia $\mathrm{FL738/.J654}$

A book of Edo period senrrē (satiric poen), with comentaries, on the subject of 18ruri stare chanting. The suthor, Oura Shake, 1s a noted researchint of old eensrō.

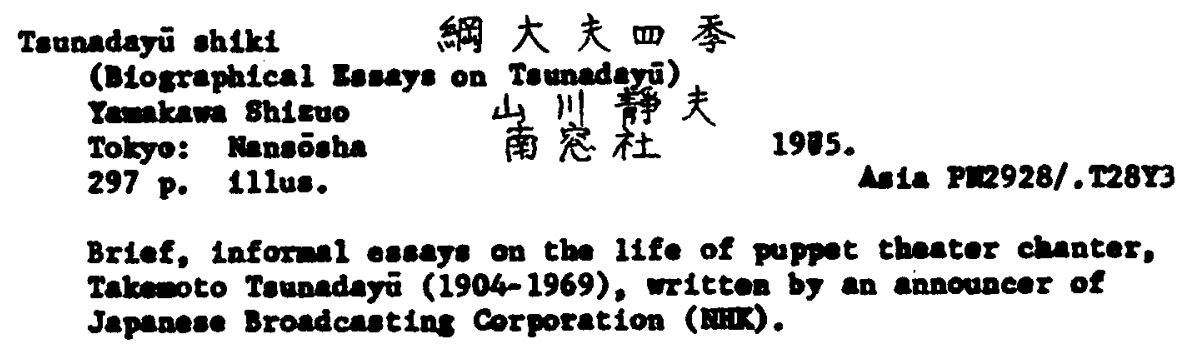

1985.

297 p. 111 s.

An1a Preg28/. T28Y3

Brief, Infornal esesye on the I1fe of puppet thenter chnter, Takemoto Teunadayi (1904-1969). Writtea by an announcer of Japanese Broadcastins Corporation (Dils). 
NITGYŌ JÖRURI - GENERAI

424 2oku bunraku no keakyñ

(Studies In Bunraku, Supplement)

Myake Shütarō

Tokyo: Sōgenshe

336 p. 111ue.

全周太郎

结丈稞 9 研究

A comparative analysis in two volwes of bunrelu (puppet ohow) and kabukt. Discuseses the differences in performances and theatrical techniques between bunrala and kabulf. Includes explanations of puppets, anecdotes of performors, interview with puppeteers, etc.

$$
\text { Zusetsu bunraku n1nggō 目説文集人形 }
$$

(Illustrated Text on Bunralu Puppats)

Miyao Shigeo 客尾しげを

Tokyo: Nikabayashi Shuppan 中林出版

472 p. 111us.

A.1a PK1978/.J3K51

An expanded edition of the author's Bunraku ningro zufu (Illustrated Handbook of Bunraku Puppets). Intended as a study of bunraku puppete with ample use of sketches, explanations are given of puppet heads, puppet arms and lege, wige, greenrooms and hand propes A brief history of puppet showe prefaces the text. 
NINGYō JŌRURI TEXTS

426

427
Bunraku jōrurieh" 丈祭淨瑠璃基

(Bunrelex Jorux1 Collection)

Tolgyo: Imenan Shoten 岩波書店

472 p. Illus. (Wibon 1965.

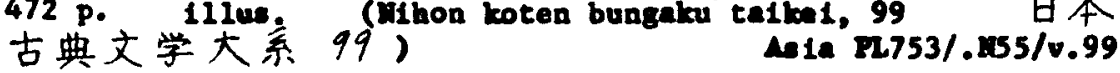

$\Delta$ collection of Iōrurt ecripte, used by Takenoto Ieunadayū VIII (1904-), of elght bunreku lōruri (peppet playe) et111 performad today. Speciel bunrala term In the ecripte are expla1ned in the headnotes and stage instruction are given in the footnotes. Interpretative coments on plaje are included.

\section{Chikenateu glkyokuchī 近松虚戋曲集}

(Collection of Dramatic Plays by Chikentsu)

Bd. by Kokunin Bunko rankoka1 国民文庚刊行会編

Tolyo: 1910.

3 .

Asia PL753/. $1655 / v .22-24$

A collection, In three voluma, of 62 10ruri pleje by Chikanateu Honzaemon (1653-1725). Included are euch peterpleces as Folcusen're keseen (The Bettles of Coxinga), Balete koforo natelare (The Girl of Hinkte). Yagtri An po karuto (Tugiri and Inaevon), etc. These works are part of the neries of rolarin bunko.

Chikanatou jorurtohi 近松淨瑠璃集

(Chikeratev Joruri Collection)

Bd. by Mura RI

Tokye: Yuhöds shoten

3 V. (Yanzds bunko
有萠堂書店４１914.

A collection, In three volune, of 42 Iorurt texte written by the noted playwtight, Chitranteu Hoszeeron (1653-1725). Chronologically arranged. Simple explantory headnotes are included in the texte. Inderes for each volum.

Chikentesu jōrurtohū (Chilamatev Jörur1 Collection)

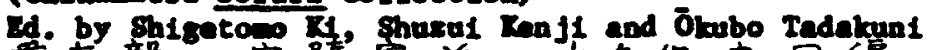

童友媇，守陵悹治，大久保忠国編

Tolyo: Iranent shoten 岩波毒店

$2 \nabla . \quad$ (Mibon koten bungalu tatkal, 49-50 B 本

古典文学大系 49-50)

As1a 22753/..155/v.49-50 
NINGYX JŌRURI TEXTS

Twenty jōrurt texts written by Chikmateu Monzaenon (1653-1725) are complied in two volume ( 14 donatic playe in Vol. 49 and 6 historical plays in Vol. 50 of thon boten bungaku talke1 Japanese Clasele Ifterature Series). The ecripte se reproducad Ilterally but to facilitate reading comprobonsion, hirerane readinge are given for konll charactere and epeclal 18rurt term are expleined in the headnotes. Sinple explanations are givan for the 20 playe.

A collection, in two voluna, of 54 jorrurt meterpieces by the famous playright, Chikenatsu Nonzacion (1653-1725). Ithe plays are arranged chronologlesily. Precading the play texte are blographical information on Chikumater and background information on verlous ecripte. (Chilenateu Honzacmon Collection) Tokyo: Shögakukan 小学館 1969. 2 . 11lue. (Mhon koten bungaku sensba, 43-44 日本 古典文学全集 43 -44) Asia R.753/.1557/7.43-44

A collection, in two volumes, of 24 donectic pappet playe by Chilenantan Yonzenem (1653-1725). The oxiginal texte were reprinted but to facilitate readins conprobension, con lana readinge axe changed to kantl characters and vice varsa. Archaic kentl wre also changed to wodern knill characters. Explanntory headnotes, keyed to the texts, and the converentional style of the play texts are also included. Discuseion of Chikemesu and eymopees of the plaje are given in the introduction ecction.

A collection of 13 IJrurt texte by Chlkanaten Honzacmon (16531725). The texte have been transcribed to cenversational otyle. Bxplanatory rearite, kejod to the texts, sre appended to each play ecript. Short esenge on Chilenetsu and his worke by seven dram critics, including Ravatake Shigetosh1, Uno Nobuo, et al, are in the concludins section. 
NINGYס JŌRURI TEXTS

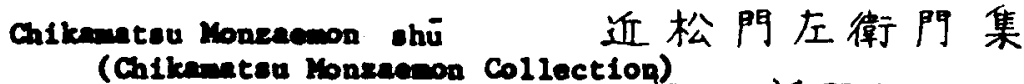

Tokyo: Aeshi Shimbunsa 1956.

3 ․ 11lue. (Nihon boten sensho

A.1e R793.4\%.053/v.1-3

A collection, in three volume, of Jorurt playe by Chikanateu Nonzaemon (1653-1725). The plas texts are arranged chronologteal1y and contaln headnotes with definitive reanrike keyed to the texts. Host of Chilranateu's dometic playe are Included as w11 as his important historical works. The explenations emphase the historicel circunstences under which the plaje originated.

Chiknantau Honsaemog ohū

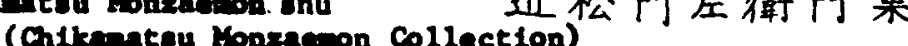
Ed. by Tolanin Tosbo Trbushikd Talohn
国民四書

株式会杜編

Toky0: 1927-1928.

2 v. (Kindal ishon bungala talka1,6-7 近代日本文学大系, 6-7)

Alie PL755.35/.355/v.6-7

$\Delta$ collection, two volused, of 47 10xurl plays written by Chikemtau yonraemon $(1653-1725)$. At the beginning of each volun, explenatione of various plas texts and Interpretations of characters which appear in the playe are given. A gloseary of apacial1zed term, keyed to the texts, is appanded.

Culkomatsu zenohr 近松全集 (Complete Works of Chikenateu) Oantre: Mainicht Shimbunobe 10 \%. 111us. 每日新閏社 1925. Ala PL793.4/.A1/1925

The couplete works of Chitranten Bonsaenon (1653-1725) are contalned in thase 10 volune wich wre pablished between 1925-1927 to commenrate the 200th annivereary of Chlkerated's death. A brief synopele and a eingle-page photo reproduction of the original text precede each play ecript. sketches of play ecenes are included. Brief comente on the texts are given In the beednotes.

(Glderü Collection)

2d. by Whenuch1 Chöfl and Tamara Mlohio 田村西男稨

Tokso: Mihon Onkyolu Zenshü Kantrōke1 全策刊行会

1927 .

3 v. (Bibon onkyola zenchū, 2, 10, 13

$$
\text { 中内蝶二 }
$$

日本音曲

日本音曲全莱，2，10，13) Lein $1.4340 / .2555 / 7.2,10,13$ 
NINGYŌ JŌRURI TEXTS

$\Delta$ collection of 99 gidera plays in three volume: two volume tit led Gideri zenehū (Gldayũ Collection) and one volume, Zolen glderd zenchi (Gidaru Collection Supploment). Both original texts and stage scripts of the sideri playe are included but for the benefit of gidard fans, etage ocripte conotitute the greater pertion of the worke. Simple headnotes are lacluded for esch play.

Hanjl glkjolachü 半 = 虚曲乘

(Collection of Dranatic Plays by Hinj1) Chiknateu banj1 近松半 = Tokyo: Eokunin Bunko Innkōka1 国民文庫刊行会 1911. 800 p. Aate $12753 / .1565 / v .26$

A collection of 11 anterpleces by Chikamatou Hanj1 (1725-1783), tōrurt playwright of the forwer Takenoto Puppet Theater. The plays are arranged chronologically. Included are Bonchō nifüchl kō (Twenty-four Dutiful Sons). Iraroe dōchü surorolu (Through the Ige Rase). etc. This work is one of tho Bokugin bunko ceries.

国民文康刊行会 1912 . Ae1a PL753/.265/v.25

A collection of 11 maeterpleces, conaletins of aine hietorical and two dowetic playe, by the Jorurt playwight, Takeda Inweo (? - 1747). Horks are arranged in chronological order. Along his worke are Kanedehon Chüshingure (The Loyal Forty-eeven Ronin) and Sugevare donfu tenarel legent (Sugavara's Secrete of Calligraphy). This work 1s one of the eeries of rukunin bunke. 正已河竹繁俊編 Tolyo: redolvaw Shoton 359 P. $111 \mathrm{us}$ (Nibon koten kandho kosa, 21 1958. 古典制賞請座，21) ista $82753 / .056 / 7.21$

Presents extracts of origlnal texts of aix representative jorurd and five labukt playe wich are still popular today. Gives beckeround informetion, eynopees and explanatory coments on the playe. A collection of short eneaye on torurt and kabulet is apponded. 
NINGYŌ JŌRURI TEXTS

440 Jorur1, kabuk1 (Jorur1 and Kabuk1)

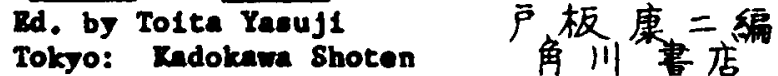

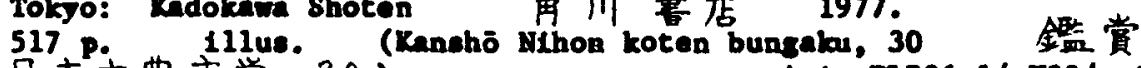
日本古典文学, 30 ) 淨环琌 - 歌筆伎

Discusese fanous acts from anons four jörurt and four kabukt plays which are performed wet frequently today. Brplanatory footnotes synopis and Interpretative comentary are presented for each play by the editor. Short eseaye on 16rurt and kabukt by nine researchers and a bibllography are lncluded at the end. 1950.

2 v. 111us.

大日本雄弁会請談社

Ae1a PL1981/.C35

A collection, in two volume, of 10 famous jorurt playe, including surawara denfu tenaral kagali (Sugawara's secrets of Calligraphy), Yochlteune eerbonsakura (A Thoueand Cherry Trees), etc. The scripte have explanatory conints, leyed to the texts, In the heednotes. Preceding each text are compatarles on firet performances, playwighte, factual backsround, related works and eynope1s. Jōrurt hietory 1s given in the introductory section of the first volum.

(Collection of Jōruri Naserpiefes)

Tokyo: Chikana Shobō

377 P. 111 .

日本文学全集，25）

1961.

1018 $753 / 066 / 0.25$

A collection of etx famous jōruri playe with the original texts transcribed to convereational etyle. Scripte Include suravera denfu teneral kaganl (Sugaware's Secrets of Calligraphy), Toghiteune setbonzalure (A Thousand Cherry Trees), etc. Concise explanations keyed to the texte, are given. Toward the and of the book are four short eseaye by noted critlcs and performere on the history of 1ōrurs, art talka of puppeteer Bungoró, etc.

(Collection of Jōrur1 Haterpigces)

Ed. by MAura RL

Tolgo: Yühödō

三浦理

3.

(Yühōdō bunko

有朋堂 $1914-1915$.

有朋堂丈度）Asie R2753/.387/v.56-58


NINGYō JōRURI TEXTS

A collection, in three volume, of 21 törurl texte writtan in aid-and late 18th century by playolghts other than Chilsantea Vonzacion. Rach volum contains eeven playe. The prefece to each volum doscribes the playwghts and plays, the firet performance detes and the theater in wich parforaed. These worke were publiabed in 1914-1915 and are part of the Muhodo bunico ser1es. Tokyo: 1927.

2 v. 11lue. (Wihon wicho Eenohū

日本名著全集刊行会編

日本名著全集） Ala PL755.35/.255/v.6-7

A collection, in two volumes, of 41 löruri anterpieces, arranged chronologically. The first of the two volumes contalns playe witten between 1685 and 1739, and Includes such we11-known forurt playrrighte as Kino Faion (1663-1742), Takeda, Irumo (? -1747), Bunkōdó (f1.1716-1735), et al. The second volume contains playe between 1745 and 1799 and includes Chikametsu Henf1 (1725-1783). Nandk1 Sōouke (1695-1751), et al. Brief explanations of vartous playe precede the texts in each volume.

(Jōruri Collection)

Tokyo: Iranani Shoten 岩 波 書 店
2 v. (H1hon koten bungaka takke1, 51-52

浄瑠璃集

1959-1960

日本古典丈学大系,5(-52)

Ad1e 8L753/.855/7.51-52

A collection, in two volume, of nine foruri texte, lacluding the h1ghly popalar Renedehon Chühingure (The Lojal Forty-seven Ronin). Bxplanatory connente, leejed to the texte, are contalaed in the hendnoten. Background Information on 10rurt and the scripte exe given at the beginning.

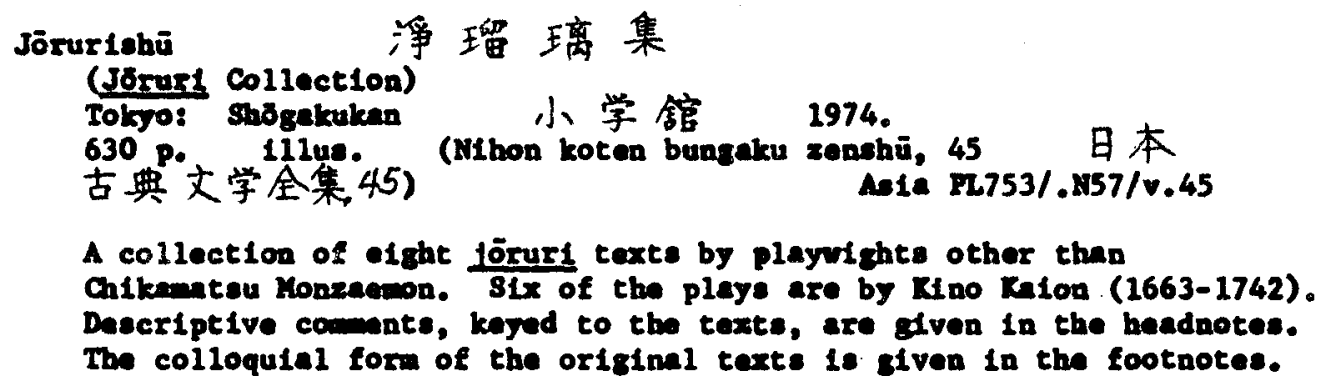


NENGȲō JŌRURI TEXTS

447

Katon Bunkōdo Kigal gikyokushu

海音文来堂鬼外歔曲案 (Collection of Dramatic Playe by Kaion, Bunkodo and Kiga1) Tokyo: Tokumin Bunko Rankokka1 $650 \mathrm{p}$.

国民文㢆刊行会 1.

A collection of 12 worke by four jorurt playrighte: $1 x$ by kino raton (1663-1742), three by Bunködo (f1. 1716-1735), two by Pukuch1 K1ga1 (1728-1779), and one by Nandk1 Sōsuke (1695-1751). Texts are reprinte of the originals with slight alternations. Explantory comments on the playwights and plays are given in the preface. This work is part of the Kokunin bunko eerles.

448 RImpirabon zenshu 金平本全集

Oeaka: Oeaka Kalntch1 Shiabunsha 大阪每日新聞”社 1926.

31 v. 11lue.

A collection of 30 kimplra 10 ruri texts intended for reading purposes. These texts are reprints of editions of early Tokugawa. perlod. (17th century), written In Japanese calligraphy and Illustrated. Vol. 1, in block print, presente the history and background information of klmplre books, and blbliographlc notes and explanatory comments on the 30 texts.

Rojōrur 1shü (Old Jōrur1 collection)

Bd. by Tenr 1 Toshoknn Tenr1: Tenr1 Daigaku Shuppambu 天理大学出版部 1972. 436, 61 Ps +111 s. (Tenr1 Toshokan zempon söaho, 9 , 团要館善本喜春，9) As1a PL768/.J6r6.

A compllation of photo reproductions of 14 old förurl texts of the Ban'e1, Shoho and Reian perlode (1624-1651) preserved in the Tenr1 Library in liara. Blbllographic notes on the 14 ocripte are appended.

$$
\begin{aligned}
& \text { I0jörur1shū 古淨瑠璃集英博物館本] } \\
& \text { (O1d Jörur1 Collection) } \\
& \text { Ed. by Torigoe Bunzō } \\
& \text { Tokyo: Koten Bunko } \\
& 11 \text { lus. } \\
& \text { (roten 古典文席 } \\
& \text { 岛越 文藏 } \\
& \text { 古典文席 } 1966 \text {. }
\end{aligned}
$$

Reprinte of three old förurl texte, collected soestime betwen 1692 In Japan by a Garnan echolar, Bngelbert Kampfer (1651-1716), and now preserved in the Britioh suseum. The texts in a ingle volume are: Röchl Shönln, Tarlk1 hongan $k 1$ and Ialoholen. Comente on Kampfer and texte are included. 
NINGYŌ JŌRURI TEXTS

451

Rojōrurishū 占弾瑠璃集

(01d Jörurt collection)

Rd. by Yokoyama Shlgeru and Shinoda Jun'1ch1 横山重. 信多纯一編 Tokyo: Koten Bunko 古典文单 1953-1971.

7 v. 11lus. (Koten bunko, 67, 79, 112, 169, 195, 252, 286 古典文庵）

Reprints In block printing of 7 voluses of Kolōrurishū (Old Joruri Collection) from the Eoten bunko serles. Contains texts by Inoue Binrimanojō, Ito Dewanojō, Yamanoto Rakudeyū and Uj1 Kaganojö. Comentaries on the texts are presented at the end of each volume. Vol. 4 contains a detalled study on Rakudayü.

Mal no hon oyob1 kojörurtshũ

(Book on Dancing and Old Jörurt Collection) Bd. by Tokumin Tosho Kabushiki Raisha Tokyo: 1928.

1004 p. (Kindat whon bungaku calket, 2 近代日本文学大系, 2) Asia PL755.35/.855/v'.2

Records and discusses the scripte of 25 köwaka-mal (köwaka dance) and 19 old lörur texte. The role and elgnificance of körakr-mal and old Jöruri In the performing arts history of Japan are taken up at the beginning. Explanatory cownente are given for som of the texts. Rôvake-min wa highly popular with the varring lords of the feudal ages and later during the Bdo perlod, Influenced the developant of torurt and songe.

A collection, in two volumes, of 25 forurt plays by Rino Raton (1663-1742), Takeda Izumo (? -1747), Chikamatsu Hanfl (1725-1783). et al. Prefacing the texte are explenatory comnonte on varlous plays and short historical comente on förurt and puppet theaters.

Sokkyo jơrurishū 説経海瑠㻦集

(Compllation of Sakkzo Jorur1 Texts)

Bd, by Yokoyman Sh1garu 横山重編

Toizyo: Koten Bunko 古典文庫 1958.

2 v. (Koten bunko, 127, 145 古典文庫, 127, 145)

As La PL768/.J6Y64 
NINGYŌ JŌRURI TEXTS

A complation of reprints of original texts used in sektsy jorurt, a form of old jorurt, which flourished during the tolcho poriod (1596-1614). Also known as sekkso-bushi and eventually becem aseoclated with ningyo-geki (puppotry). Eech of the two volumes In the Roten bunko series contelne four plays, including Anida-nomunewari (Chest Splitting of Anlda), Tench1 Tennō (Enporor Tench1), atc. Bibllographic notations on the playe are appanded.

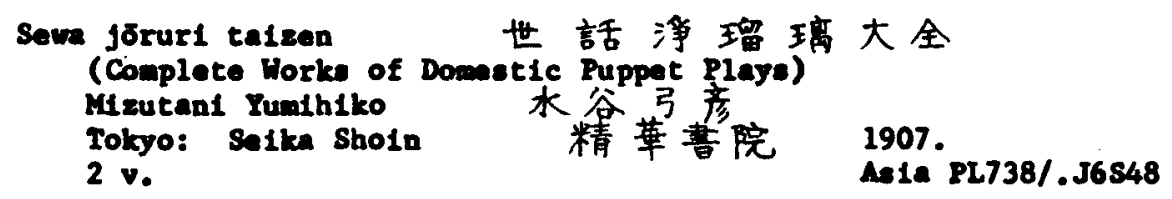

A compllation, in 2 volumes, of 40 domestic puppet plays which were consldered popular and representative of the period in which they were written. Pawous 10̈rurt playwrights Include Chikamateu Monzacmon (1653-1725), Chlkamateu Banj1 (1725-1783), Kuno Kaion (1663-1742), et al. Brief explanations of selected materpleces are given in the introductory eection. 
MOH - GENRRAL

Chüse1 ge1nöbunka sh1ron

中艺芸能文化史离

Treatises on Cultural History of Performing Arte in Mddle 48es) Ogata Enmiklcht 尾形象吉

Kyoto: Sanwa Shobō 三夈掊房 1957.

548 p.

Asta Pa2922/.033

Traces the origin and development of the noh drame in the late Middle Ages. Discusees the historical and cultural aepects of the precureors of noh, such as aruraku, dengeku, etc. Bxpleins how noh comblned the different features of these performances and becan the prototype of modern parforning arts.

Chūse1 hyōronnhūs karon rengaron nōgakuron 歌論! 速歌铪. 能染論

(Collection of Criteical Beviem of Middle Ages: Theoretical Commentarles on Vale Poens, Linked Verees and Boh Writings) Ed. by Fukude Atdetch1 Tokyo: Kadokawa Shoten 福田秀一 440 p. 111us. 角川素店 1976。” 古典丈学。 24) (Kanchö Whon koten bungake, 24 Alia PL726.1/.1233

Divided Into three sections, two on poetry and one on noh, and an appendix of short, critical coments on literature of the Midde Ages. The noh section conolete of an introductory article explaining zeani's noh thoories as exemplifled in his Füht kaden (Bastc Noh Principles). Sagents of Püsht keden ere then presented with detalled comeontar1es. Further coments on zani's theorlos are contafned In the appendix. (Racords of Banan and Othar Berformances) Honde Yesuj1 Tokyo: Mgaku Shorin $144 \mathrm{p}$ 本田安次 AnIa 212924.5/..5H651

A reproduction of records of ennen porformances etill exiuting in outlying areas, Includins Mt. Minobe (Yamanasht prefecture), Hikles, Furolene (Yangata prefecture), ete. Ennen was a progren of misc and dance held at Buddhist temples in the Mtdde Ages and only vectiges st111 rewin. This work also contalns enterials on folk dences of the Tohokn dietrict.

Tolau Hotomen

Tokyo: Myal Shoten

288 p.

$$
\begin{gathered}
\text { 你江元正 } \\
\text { 三弥井書店 }
\end{gathered}
$$

1976. 
HOH - GENERAL

The noh dran is a vestige of the Mddlo Ages et111 reanining today. From this standpolnt, the author attenpts to grasp, through noh, the culture, literature and local custone of Japan during the Middle Ages.

Gek1tek1 kükanron: nōgel n1 mirareru "hı́" no lal kösō

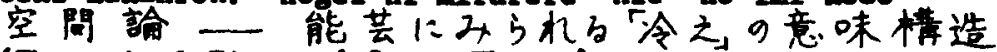

(Theatricel TIne and Space Theory)

Kor Inaga Mich1o

Tokso: Ofüsha

242 p. 11lus. 森东道夫 椄相杜 1969。

A collection of treatioes on theatricel art, particularly on theorles concerning noh. Comente are made on time and space concepts affecting the noh drand. The focel point of this work 1s the author's Interpretation of "hie" (loosely interpreted as selflese, tmpasstve solitude, term used by zeant in his writioge to enphasise that epiritual attalnent etands above technique for mestery of the noh art).

461

Conj1 monogetar1 o teima n1 nō no yügemb1

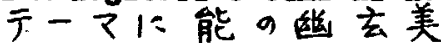

(Dieplay of Iüren Beauty of loh with Iale of Canil as Thow)

Tokyo: Mantch1 Shimbunshe

每旦新闻社 1978 .

1 111ue.

Ala PN2924.5/.216B58

Displaye color photographs of noh maks and costuese assoclated vith the Iale of Conif. Item are from the rare collection belonglng to the descendants of the former feudal lord, Hosokawn, of Aigo (Rumnoto prefecture). Ixplanations of the articles are appended.

Rana to yojō: $n \overline{\text { no seka1 }}$ (Plower and Sugeretivanas: World of Boh) Baba Altro Kroto: Tankobaha 场考市子 228 p. 111ue. 溇交社

1975. 花已余情—能9世界

The authorese, wo 1s a postese, probes into hene (flower or freabnees) and yois (angsestivenese), epiritual qualities found in noh anserpieces.

宝生 (Hōh Ed. by Boohd Ankleosho Tokyo: Dan'ya shoten 1964- 1973.

宝生発行所 わんや害店

Anta $7212924.5 / .176868$ 
MOH - GENERAL

A wothly noh orgen of and published by the Hosho school.

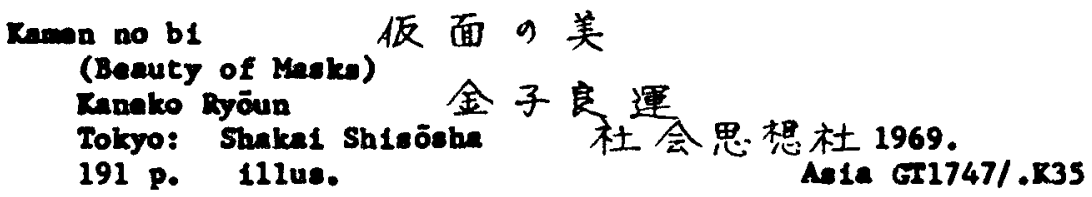

To deapen the appreclation of their beauty, make used in noh, krögen,

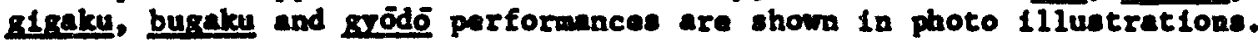
Concise explanations are siven.

A wothly noh organ of and published by the Ranse school. (Collection of Woh Masks Banded Down in Kanze Randly) Bd. by Katayana Kurōemon Tokjo: Hinok1 Shoten 1 v. $111 \mathrm{ua}$. 片山九郎街政编 1954. Anse $5 T 1747 / .1338$

A collection of photo 1lluetrations, with captions, of 100 noh manks which form a logacy of the ranze failly. Consiats of four parts: unt1l the birth of noh maks, ankers of noh make, creftmensbip and spacial features of noh mask, and bojgen maks. Byoto: Tankōabe 220 p. 111us.

$A$ beglnnor's guide to noh apprecletion. With the use of color 11lustrations, Introduces noh drama through lte various facets: hlotory, roles, faces, opace, tim, sounde, colore, actins pattern, etc.

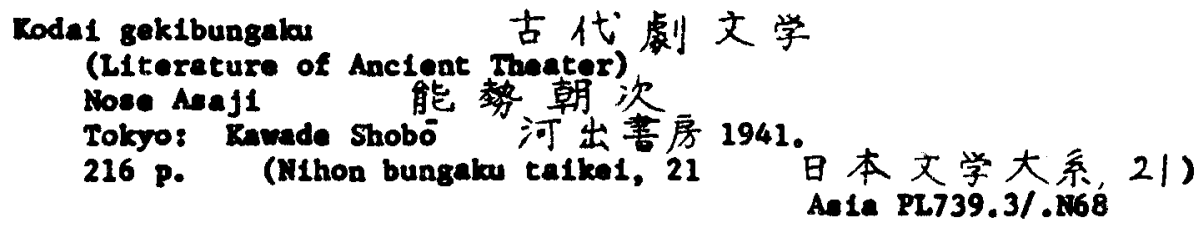


HON - GENERAI

Ronō 专 能

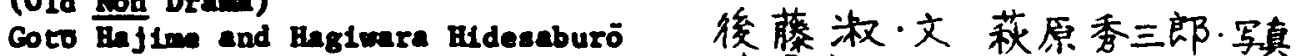

Tokyo: Rawade Shobó Shineha 河出妻房新社 1970 .

197 p. 111us.

Aata Fo P1R924.5/.1260675

Malnly through photographe, this follo-elsed work Introduces old noh drame, vectiges of which st11 extot in the regional perforning erts, festivale, eneual ovente, etc. throughout the country. Bxamples are Takachlho yokerura of Migasak1 prefecture, Hora1j1 dengabu of Alch1 prefecture, omizutorl of Todalj1 temple, Bara prefecture, atc.

Xurokawa no 黑 川 能

(Kurokawa Hoh)
Bd. by Yokoonlch1 Mar10 平横道方里雄編
Tokyo: Heibonsha
172 p. 111us.

With ennotaced, large color photos, this work vividly portrays from preparatory etages to actual performance dates, the Kurokawa noh which has becone a deeply-rooted festive event in the lives of the people of Xuroknwa villege in Yamgata prefecture. The latter part of the work 1s devoted to a sudy, centering on the history of Vurokawa noh, by respective experte. Becently, the Rurokawa noh has cose into the limelight a a regional art, retaining the vestiges of old noh dran but this work 1s the firet attempt to present a comprehensive orientation.

Burokawa nö: nōaln no gelkatsu to ge1jutsu

黑. 川 能 震民9生活を芸術

(Rurokawa loh: Lives and Performing Arts of Farmera) Makabe Jin 真壁 $1=$

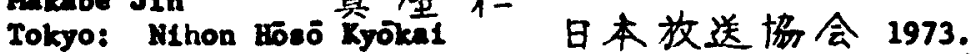

284 p. 111us. Alie P12024.5/.216\%25

Baports on the Jurokawa noh, a form of serugeku noh, which has been paseed on for generations, In Kurokawa, Tushibiki village, Higent Tagava county. Yamagata prefecture. The author is frod the same prefecture. Bmphasizes the point that the Iurokava noh has becone a part of the lives of the farmers, e.8., In village festivale and events, and is firmily implanted as a local art. (HAstory and Local Color of rurokawa Noh) Togawe Anshō Tokyo: Chüó Shotn 288 p.

F 川 安 章 中央轱院 1974 . Asta PR2924.5/.N6T55 
A research presentation on the locel customs which nurtured luroknas noh and on its historical evolution. Includes old recorde which serve as source matertals for etudy of Turokawa noh.

We1j1 nögakueht joseteu

明治能楽史序説 (Introduction to Kij1 Porlod Noh History)

Furukawe Hiseaht

Tokyo: Wan'ya Shoten

349 p. 111 us. 加节妻店 1969 .

Asia PN2924.5/. M6F87

Comprised of three ections: "Outilne of Malj1 Perlod Hoh History," "loh Rasearch by Buropease and Americans," and "Study of Waffl Reriod Noh History." The second section presents a detailed report on the research and understanding of noh by suropens and Americans, including the followlag: Barnest Frnetsco Penollosa (1853-1908), Willien Butler Yeate (1865-1939), Arthur Dav1d Wales (1889-1966) and Roe1 Par1 (1856-1922).

474

Kon ucht ayümon

面打与入門

(Manual for Making Masks)

Nagasawa Uftharu and Wataral Kalouka 長沢民春，渡会殸介 Tokyo: Hich1bō Shuppenoha $\theta$ 貿出版社 1976.

207 p. 11lus. Asta PN2924.5/.216133

A manual designed to reveal the secrets of meak-making and to enable even "amateurs" to make thom. Amply 111 ustrated with charte and photos, the menual gives step-by-step Inatructions on the making of maske.

Whon geldō to bukkyō no kokoro (Spirit of Japanese Arte and Byddhise) Iringe Yanoru

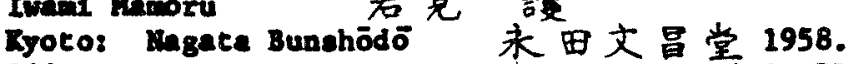
266 p.

日本芸道と佛教の:二 岩 恶

A compliation of the author's eseags on appreclation of Japenese arts and noh from a Buddhistic etandpolnt. Similerities exist in the training practices of Buddhion and Japanese arta; to wit, cultivation of certain epiritual qualitios uch as auddon enilghterment, realization of the transitorinese of worldis thinge, etc.

(noh)

Mavuda Shözỏ and Kaneko Ka1so Tokyo: Yalnich1 ShLmbunsha 285 p. 11 lus.
增田正造解説；金子桂三写真 每日新聞社 1974 .

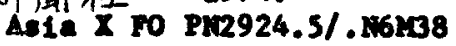


NOH - GERERAL

A total of 117 photos (large-sized, both color and black/wh1te) are used to deplct noh. Divided into noh mak, noh play and noh theatre, noh play and local noh play. Explamations of axch photo are apponded. An explanation, In Engliah, of noh is also given at the end of the book.

(20h) 能

Hoel Pert Tr. by Iguro Takeak1

Tokyo: Öfüoha 校根杜

228 p.

ノエルペリー井畔武明訳

1975.

Asta PM2924.5/.116647

Introduction to noh by loel Peri, a Frenchman, wo arrived in Japan as a Cathollc alesionary. Served as an instructor at the Tokyo Mus 1c School. The book, titled in lo (1944), was trans lated and firet poblished by the Mich1-Futeo Katkan (Mison Franco-Japona1eo).

(Nob)

RIchard MckInnon and Makamura Yauvo リチャードマソキ/ン，中村保雄 Kyoto: Tankōshe 淡交社 1967. 270 p. 11lus. (Elhon no dento, 2 日本9伝統, 2) As 1e $5 \times 584 / .155 / v .2$

With ample use of illustrations, this work introduces noh as one of the traditional Japanese arts. It 1s one In the series titled, Ireditional Art of Jepan. Begina with an eseay by Richard Mckinnon

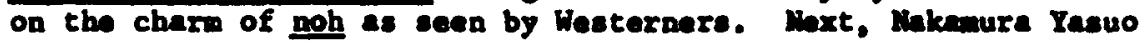
presants a comparative andyais of noh (as a for of Japanose stage art) and western dramatic show. A historical account of noh follow. Than, the present poh world is introduced, Includins noh parformers, make, costunes, haod prope, etc.

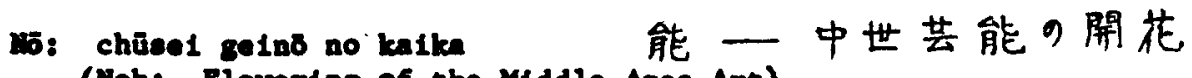
(Loh: Flowerlas of the Mddde Ages Art) Ed. by Gelnonh1 Tonkyaka1 Tokyo: Belbonshe 平凡社 1970 . 365 p. 112ue. (M1hoo no koten seinō, 3 日本9古典芸能, 3) Ale $\mathrm{PL2921/.25353}$

comprised of two divisions. The firet is a hietorical research of noh. The second takes up noh from ang viempolnts and is a collection of research trentises of saclallsed aspacts, Including chant texte, enske, costures, wasic, etc. 
NOH - CENERAI

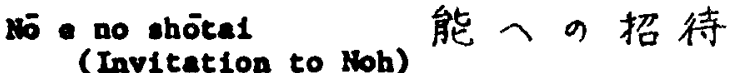

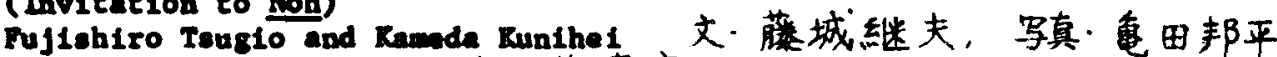
Tolsyo: Wan'ya Shoten 巾人や喜店 2 v. 1973. Ala P12924,5/.016777

Presents over 60 fanous noh plays together with atage photographe. Points out and explains the important points of the plays. A siaple guide to appreciation of noh.

能蔡大辞典

(Hoh Dictionary)

Shöda Shöj1rō and Amentya Kan'1ch1 正田童次郎 雨宫幹Tokyo: Toohtkawa robunkan 1425 p. 吉川弘丈館 1908 。

Consiate of three sections. The firet section is the "min text saction" which 11ats, in Japanese eyllable order, 262 noh plage witk the Ranze school as the basis but Including other schools. Tho nils. and supporting actors, playrighte, etc, are listed for each play. The second section 1s the glosesry explaining noh text teratnologiex. The third is an explanatory section defining difficult phrases, ancient events, Buddhietic terws, proper nouns, etc.

Nogeku denso 能集 談畨

(Conentaries on Moh Drama)

Yoko1 Heruno 棤排秦野

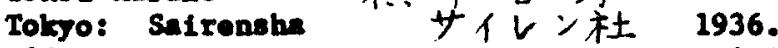
386 p.

Aeta P12924.5/.216864

Couplled by the author as an ald in the wovemant to popularise the noh drame. The first half of the book presents basic knowledge of noh and chants. The latter half is a collection of the author'. rovelations of his noh chant training, essays on noh drame and articles on visite to places noted in noh plays.

Wögaku fudok1: nögnku no rek1sh1 chir1tek1 kenkgu

能楽風土記 能桨9歴史地理的研究 (Local Color of loh: Bfptorlcal and Goographical Reeearch on loh) Yabuta K11ch1rö Tolyo: Hinoki Shoten 344 p. 椟由喜 意店 1972. An1a RL735/. 224

$\Delta$ historical and geographical research on noh. The firet part focuses on noh playe and the second on the history of noh. 
MOH - GENERAL

484

\author{
Nōgaku gahō 能贸 画 報 \\ (Plctorial Review of Noh)

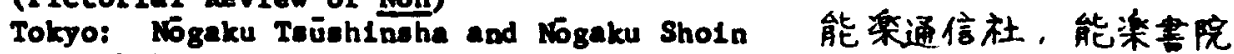 \\ 1909- 1930 .
}

As1a PN2924.5/.013636

A monthly, lllustrated periodical on noh.

Mōgaku genryūikō

(Study of the

Nose Alej 1

Tokyo:

1555 p.

Gives a detailed description of the origin, development and traneition of serugalou from the ancient age to the early modern period. Sectionalized Into the sarugaku of the HaIan, Ranakura and Yosh1nochö, and Muronach1 perlods. This work is valued as a reference for historical research on noh.
能楽筆陣

$$
\begin{gathered}
\text { 坂本雪茑摆曲行所 } 1942 . \\
\text { As1a PN2924.5/.116824 }
\end{gathered}
$$

能染源流考

旨努朝次

Asta PN2924.5/.146N683 of Noh)

岩波書店 1938 。

A compilation of the author' random thoughte on noh which had been published in periodicals or which had been presented by the author in public lectures. The author touched on subjects such as zaani and modern noh, appreciation of noh, etc.

Bögaku hyakuwa 能隼百話

(One llundred lioh Iteme)

Bd. by Sanke 1 Shimbunsha

Kyoto: Shinehindo

245 p. 111 us.

馭々艺ンケイ新聞社編

駸々堂 1978 .

As1a Pr2924.5/.126534

A compliation of short essays, concerning noh, by 100 persons from the present Iiterary, comentary and parforming art circles.

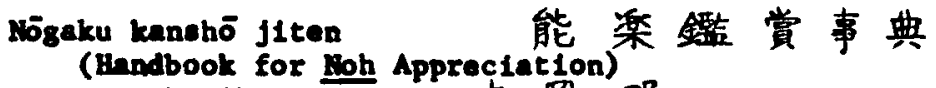
Meruoke Akira Tokyo: Rnwede Shobō Shinche 河出書房新杜1961. 475 p.

\author{
Ala Ref. P12921/.M26
}


NOH - GENERAL

Consiste of three chapters. Chapter 1, "Explanations of Ioh," d1scusses the essential alements that ina up a noh drana, Including the types and composition of playe, performara, weic and chant, -tage settinge, etc. Chapter 2, "Apprecietion of Moh;" is the min body, presenting the aynope 1s and interpretations of 255 plays. Chapter 3, "Hletory of Hoh, etc.," gives a conclse historical account of noh and touches on niscellaneous iteme.

Nögaku kenkyü

(Noh Recearch)

Nose Asaj1

Tokyo: Yókgokukat 能筇 朝 次

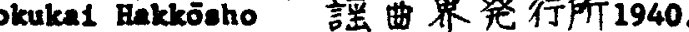

315 p.

As 1a PN2924.5/.N6N68

A compliation of the author's treatises on noh. Explains the etudy of noh and the relationshlpa between noh and 2 an Buddhiom, art of veraification, etc.

Nogaku kokonk1 能梁古今 記 (Record of Anclent and Kodern Noh) Monomara Kalzo Tokjo: Shunyodo 383 . p. 野令村成三 春陽堂 1931 。 An1a PN2924.5/.146N652

A hlotorical account of noh from its origin up to the Kijl era. The firat part deals with the various noh schools and the second with provinclal noh.

Nögake koman taikna 能學古面大嗂 (Ganerel Survey of O1d Noh Magke) Ed. by Iongo Imao 金阙編 Kyoto: Nakajime Ceashokuban Insataugho 1930.

12 v.

11lus.

中鼠原色版印䐖所

A folio-eixed work, displeying wth wounted photo 11luatrations, 60 old noh asck preserved in the Kongō (noh school) famtly, Tokyo National Museum and other places.

Nögaku no kigen

(Origin of nol)

Gotō Haj 1 in

Tokyo: Wokuj1sha

586 p. 11 lus.

能楽の起源

聁藻淑 木耳社

1975.

An 1a PR2924.5/.N6664 
NOH - GENERAI

A voluminous work of over 500 peges to prove the assumption that the fountainhead of noh is earugaku. To seek clues and evidences, nov source materials wuch as provincial, ethnic resources, references on makk, etc. were researched in addition to noh history meteriale. In the concluding eection, the procese by wich noh wes estableibed 1. briefly ltemized.

Bogaku reisan 能沓 礼稘

(Adratration of Noh)

Togawa Shükotsu

253 p. 111us.

户川秋骨 大岡山婁店 1931 。

Asia PN2924.5/.86T63

A compllation of random essaye ooncerning noh by the author who is a scholar of Bnglish literature. Comparisons between noh and Weatern clessic theater or opera occasionally appaar in the work. However, the greater part of the work conslats of praiees for the artistry of Rite Roppeita (1874-), head of the Rtte shool of noh. At the end of the book, there are 74 plates of photo 11 lustrations of noh masks and stage scenes.

Nōgakuron to bungaku se1ohin (Noh Theory and Literary Splrit)

能楽論と文学精神 Hisameter Sen'1ch1 久松潜 一

Tokyo: Kokumin Seish1n Bunke Kenkyūjo 国民精神文化研究所 1935. $106 \mathrm{p}$.

The author, who 10 a Japanese I1terary scholer, discourses on the relation between noh and poetry and evaluates noh from a literary etandpolnt.

Hogakuron zu1sō

䏍笑 論 陵想
(Randos Thoughts on Noh Theory)
Tarese Rasuma
11) 涑 一責
Tokgo: Wan'sa shoten
わんや害店 1967 .
252 p. 11lus.

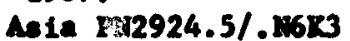

A coapliation of the author' 45 randon essays concerniag noh. The athor's intent is to describe the ignificant characteristics of noh art and to define its role in Japanese culture.

Nögaku sandanghō

(Woh In Three Parte)

Tok1 201naro

Tokgo: Shunfūshe

339 P.
能楽三断抄

土岐善磨

春秋社 1942 。

Asia Pr2924.5/.206T648 
MOH - GENERAL

A compliation of randon eseaye and comentaries on noh texts and performances and on his own personal experiences in noh activities by the poet, Tok1 zotaro (1885-). The book t1tle reflecte the three parte or stages of learning identified a comon to suddhistic and noh training. The book is also divided into three sections $\mathrm{rgs}$ thoughte on claselc noh plays, woso of a novlce and tribute to new plays. An Interesting feature to the appendix which contains the pros and cons of a number of exparts in the fleld as to whether now noh plays hould be written elnce the value of noh play 1 considered to 11e in its old tredition.

497

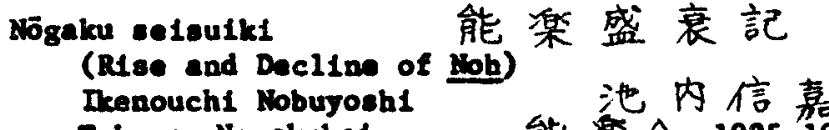
Tokyo: Hogakuka1 能楽 2925.1926 . 2 v. Ala PU2924.5/.166I64

A hietorical account of nob in the wodern age. Traces tho evolution: and transition of noh during and subsequent to the Bdo parlod. Vol. 1 describes noh in the Edo period $(1600-1868)$ and Vol. 2 covere the Maji and Teisho periode (1968-1925).

(Noh Trend)

Tokyo: Nogaku Sh1chסahe 能梁思潮社1964-1973.

Nos. 29-62.

A blmontbly noh perlodical which is no longer publiehed. It had been a composite magarine containing commentaries, eseaye, reviows of noh parformances, new of the Hoh Assoclation, etc.

Nogakush1 kenkyü 能楽史研究 (Study of Boh Hilatory) Kobayashi Sh1zuo Tokyo: Treankaka 242 p.

小林静雄 雄山居 1945 .

As1a PW2924.5/.1167621

A noh history centered on representative noh actors of the different periods.

Nōgaks: sh15yō 能案史料：第一輯

(Noh Historical Meterials) Kobayash1 Sh1suo 小林静雄 Tolsyo: Doknyam Shoten 大网山萋店 353 p. $(v, 1)$ 
BOH - GENERAI

A collection of noh hietorical ateriale arranged in chronological order. Materials conalst of Itens concerning noh Including dengeku, kusenel, ennen and meteubayashi, culled from the diarles kept bJ court, eamural fantiles, Buddhist temples and Shintō shrines or from reliable ancient recorde.

Dögaku yökyolau da1j1ton

(Dictlonary of lioh Texte) Shoda shōj1rō 正田章次郎

Tokyo: Yosh1kawa Köbunkan 吉li 弘文館 1935. 669 p.

Asla Ref. PN2924.5/.N6S54

Revised and enlarged edition of Hoh Dictionary of Yoshikawa Kobunkan (1908). The technical term section of the book contain a compreheneive liet of terms pertaining to noh texts, based on the kanze school. The explanation section contains definitions of difficult teras in the texts. Arranged by Japanase eyllabary.

Hōgaku yōkyoku daijiten fusu (IIlustrated Dictionary of Amomiye Kan' Ichi Tokjo: Selkōken Shoten 1 v. 111 us. Asla Ref. PN2924.5/.N6S54/Suppl.

A collection of colored drawinge of theatrical lteme for the performances of noh drama. Draulinge of aneks, costumes, hand prope and stage properties are 1ncluded. Draulnge are useful as practical reference materials to stage noh performences.

Nogaku sama1 (Imanraton in Noh) Takekosh1 Tanzo Tokso: Wan'ya Shoten 218 p. 111us.

An autoblography of the author who epent fifty years of his life imoreed in noh play.
能 楽三昧<smiles></smiles>
わ火や喜店 1963. As1a P212924.5/.106T35
Hōgaku sensho 能愁全塞

(Complete Works on Noh) llogand Toyolchlrō Tokyo: Sögensha $6 \mathrm{ve}$ 創元社典

Asla P212924.5/.106\%638

A series, in $81 x$ volumes, contalning a comprehensive coverage of Information required for the otudy of noh and brōgen. The $1 x$ volumes are: (1) Art Theories of Noh, (2) Hiatory of Noh, (3) Literature of Noh, (4) Performance of Noh, (5) Noh and Krogen and (6) Appreciation of Noh and Kyōgen. 
NOH - GENERAL

505

$$
\begin{aligned}
& \text { Nōge1 ron 能䒧 論 }
\end{aligned}
$$

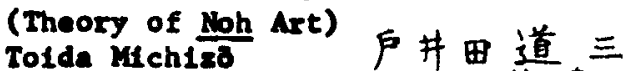

$$
\begin{aligned}
& \text { Tokyo: Ke1ed Shobs 峌草害房 } 1965 . \\
& 392 \text { p. 111us. Ala PH2924.5/.116T64 }
\end{aligned}
$$

A study, through noh, of the epecial characteristics of traditional Japanese culture.

No: honsetsu to tonkal

能：本説，と展開

(Wh: Source and Developmental Materials)

Mineuda Shozō 增 由 正造

Tokyo: Ofüsha 校相社 1977.

229 p. 111us. An1a PL765/.N5

A compilation of representative noh plays, tracing atories or poem on which the play had been based and in turn, Identifyling kabuk1 plays which had developed from the canis joh playe. Th1s work was complled for use as college Inetructionat materials In Middle Age 11terature, dramaturgy and comparative literature as well as for entertaining reading by the general public. Examplea are: Rashlwagl of Tale of Gent1 and Nonomlya of noh and Ron laku monogatar1 and Dojoj1 of noh and 11kewise, Dojol1 of kabukt. A comprehensive collection, this work also contalns the following: new noh play. Resurrection, based on the Gospel of John from the New Testament; Iyric dramse by W1Il1am B. Teate (1865-1939) who is cald to have been Influenced by noh; and Takano fzumi, a noh derived froa Yeate' play, At the Hnik' Well.

Wō kabuk1 no shöta1

能・歌传へ9招待

\section{(Invitation to Noh and Labulk)}

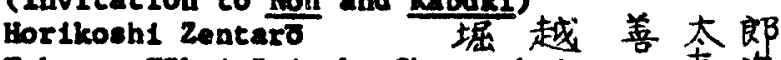

Tokyo: Toka1 Dalgaku Shuppanka1 東海大学出版会 1975. 214 p. Ala PH2924.5/.N6H58

Through photo 11luetrations, with explanations, introduces etage ecenes from Matsukese (Pine Wind or Sisters of the Sesshore) of noh and Kumnge1 fin'ye (Kuragal's Camp) of kabuk1. This work is intended for those with interest in noh and kabukt but who have seldon seen real parformances.

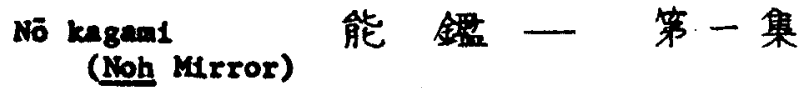

Byoto: Da1kodõ Bnok1 Yokyoku Shoten 大瓜堂桧謡曲書店

$1 \mathrm{ve}$

An illustrated periodical on noh. Vol. 1 contalns photos, with explanatione, of the atage figures of Ranze Motosh1ge (fl. late Talsho par1od), 24th head of the Kanze school, and other noh performers 
NOH - GENERAI

of the same school. Includes name of plays and perforwers, roles, dates, places, contumes, etc. Bxamples of playe are Dojo11 (DSjoj1 Temple), Hegorono (The Angel's Robe), etc. Aleo enkes reference to the Tanse family possessions, handed down for generations, Including costume and a Higashlyam tebako (Box for Personal Effecte) recelved by the Kanze fandly from Shogun Ahtkage Yoshlonea (1436-1490), and presently used as membako (noh anok contalner).

Nó kagem1 能 佳 雅 美

(Noh Beaux Arta) $\quad$ 芸州堂 1934 .

1 v. 11lus. An1e $80 \times$ ND1059/. 264

A compllation of follo-sized illustrations, aninly color, of noh costumes, masks, hand props, etc. selected from the Kanse fanily possessions. Includes 15 loose leaf plates of noh mask akecches by the artist, Matsuno Sōfü. Enclosed in a bound rooden box.

15: kami to koj1ki no geijuteu

$$
\text { 能一柛と气食の芸街 }
$$

(Hoh: Art of Cods and Beggers)

Tolda Mich1zó

Tolyo:

户井田道三

317 p.

Serike Shobō

世多書度 1972 .

As1a PH2924.5/.116T573

A guide to underatanding the role and elgnificance of noh in the world's theatrical bistory. The firat half of the book describes the pecullarities of noh, Including the restricted etage with pillara and without a curtaln, entrance of $80 \mathrm{ds}$, begsars and supernatural beinge in plage, use of confining faclal mask, etc. The latter half is devoted to zeant, noh as viewed by Westerners and aspecte of the prinitive world wich are reflected in noh. The author trles to conalder noh from a philosophical vieupolnt, particularls 1ts sesthetic contribution to the theatrical developwent of the world.

15: kencho no tement (Noh: for It: Appreciation) Karuokn Daljl and Yoohtkosh1 Tatouo Osake: Bolkubhe 153 p. 111ue. 保育杜

A handbook for the appreciation of noh. ong of noh plays, from the firat, rak1 noh (god play), to the flfth, k1r1 noh (concludins pley). At the end of the book, there are explanations providins information neceseary for the appreciation of noh, Including an article, "What Hoh Is." 
NOH - GERERAL

512

No katatsuke 能 型 付

(Records of lob Dance Patterns)

Bd. by Weseda Daigaku Bngok1 Bakubutaukan 早稻田大学

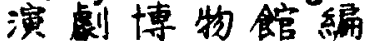

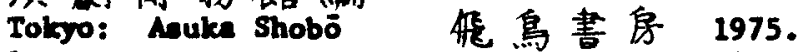

1 v.

An1a PRR924.5/..262154

A collection of photo reproductions of three sets of noh dance pattern records which had been transmitted from the Bdo perlod. The records cover varlous noh schools and are in the custody of the Waseda Univere1ty Drann Museun. The three sets are: "Lieting of $100 \mathrm{Boh}$ Playe," "Lleting of $50 \mathrm{kbh}$ Plays," and "Llattng of Hoh Blaye." For the total of 174 playe 11sted, the dance pattern for exch has been documented in detall (noh katatouke). There are no explanatione for the plays or dance pattern documentation.

W0: kenkgü to hakken 能—研究と発見

(Hoh; Rasearches and D1scover1es)

Nogani Toyolch1ro

Tokyo: Iranant Shoten 峞波書店 1930.

302 p.

Asia PN2924.5/..N6R642

A selection of research treatises on the dranetic composition and asethetic values of noh. The author is a scholar of Inglish litereture and atteapted to popularize noh in Japan and overseas. This work is a selection of the suthor's treatises publiabed in perlodicals betmen 1921 and 1930.

15 kyögen jörur1 kabuk1 能狂言浖琶璃歌舞伎 (Boh Erösen Jörurt Rabuk1)

Hoee Anj1, Shusul Kanj1 and Kondya Toyotaka 能朝次 守陵富治小宫曹隆

Tokyo: Shibundo 至文堂 1951 .

220 p. Alia PN2924.5/.11611684

A collection of esaeye on the clesele performing arte of Japan by noted writers: Noee Aajj1 on noh kyoren. Shusul Kanj1 on forur1 and Komiga Toyotaka on kabukt. Complled with the objective of epreading and deepaning the public underetanding of these arte.

N8 kgögen nyümon 能狂言入門

(Culde to loh and srören)

Minceuda Tenoteu 松田存

Tokyo: Bunken Shuppan 文研出版 1976.

342 p. 11lus.

A beginner's gulde to noh and byogen with many photo illustrations of stage acenes, costumes, naks, etc. Part 1 takes up noh and 
NOH - GENERAL

part 2, kyōgen. Hıstorical backgound, performing echools, categories and aynopsis of playe, efgnificant points of play, etc. are concieely explained in eimple terme.

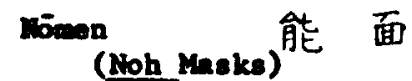

Shirasu Kasako

Tolyo: Kyūryūdō

115 p. 11lue.

白州正子

求龍堂 1963 .

A collection of photo illuetrations, with detalled ceptions, of noh make. A totgl of 37 ancks are show in page-siced photos. Masks Include oltina (old man), oane (womn), ehōtó (mythological oranguten), etc. Brief historical background of meeks 1s given. Also, there is an Bnglieh explanation at the end of the work.

Nowen: cono sekal no uch1 to soto

能面ちとの世界の内と外 (Hoh Maks: the Interlor and Exterfor World)

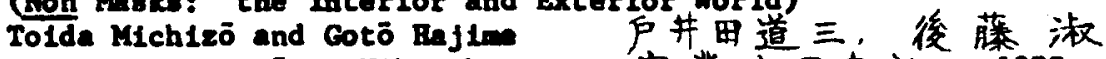
Tokso: J1tsugyō no Mihonsha 実業之旦本杜 1977. 226 p. 11lus. As1a Pi2924.5/.1065575

Two witers, who are noted as historical researchere of noh, collaborated to give a simple but detalled explenation of the hietory, types, etc. of noh makes.

NEwen ronko 能面 論考

(Thoughts on Hob Macks) Nogand Toyolchiro Tokyo: Koyane Shoten 335 p. 11lus. 野上貫一郎店 小山曹店 1944 。

Primar11y a treat1se otudying noh and byōxen maks from aeshetic and choreographic atandpoints.

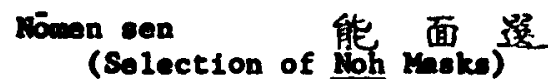

(Selection of Woh Maks)

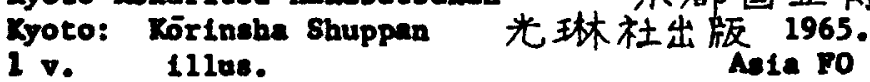

Aeta PO GT1747/.296

A compliation of 100 large-sised photo 121tetrations, aninly of color and with explanatione, of noh aneke dieplayed at the kyoto Nationt lusoun in the fall of 1964. There to a short Bnglioh explanation titled, "Moh Mask," at the end. An Baglish MLiet of Plates" (photos) is also appanded. 
MH - GBRERAL

Nömensh1 kenkyū josetsu 能面史研究序説

(Introduction to Study of Boh Mank Bietory)

Cotō Haj1en 後藤淑

Tokyo: Malsendo Shoten 明善堂暂店 1964.

1 v. 11lue.

A collection of black-and-white photos of over 100 mack of noh, and tts precurwors, earugalu, dengeku, etc., preserved in provincial shrines and temples throughout Japan. Deteiled explanatione of each makk are given. This work constitutes a valuable reference for the study of the history of noh maske and the origin and davelopment of the noh dram, as wall.

521

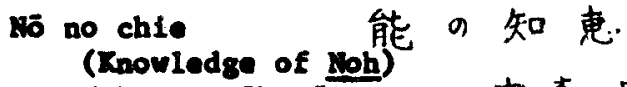

Ninkenor Shoso 中森晶三

Tokyo: Tamagava Dalgaka Shuppanbu

264 p. 111us.

王111大学出版部 1976 .

Asta PN2924.5/.206123

A beginner' gulde presenting in simple terminology the noh art theories of the or 1ginators, Rannani and Zeavi. Part of the series of the author's works, $15 \mathrm{no}$ sueume (Encouraging $\mathrm{BOh}$ ), 150 no aldokors (SIgnifleant Rolnts of Woh), etc.

Nō no desain

(Hoh Dosigne)

Minsuda Shōxō

Tokgo: Helbonshe

143 p. 11lus.

$$
\begin{gathered}
\text { 能のデザイン } \\
\text { 增田正造 }
\end{gathered}
$$

1978.

As 1a PLR924.5/.116438

Discuses the color and deafgne of noh maks and costunes frow the etandpoint that they form the esence of noh drana. Through numerous color photos and drawinge, expleins eimply and concretely the excellence and beauty of the designe.

wo no ehon

(Picture Book of Hoh)

Kimare Toshiyruk1

Tokyo: Aluke Shobo

375 p. 11lue.

能の絵本增㭪

木村利行

熊鸟書房 1978 .

An eseay collection on noh iritten as a eimple, informal orfentation guide for beginnere. Illuetrated by the author hineelf.

524 t5o no enshutsu kenkyu

(Study in Staging woh Performances)

Myake Yuzuru 三 宅 㜪

Tokyo: Hōgaku Shorin 能楽音林 1948.

241 p.

As 1e R12924.5/.176\%58 
NOH - GELERAL

A treatise by a fanous noh critic explaining the fundamental elemente of noh performances and analyaing etage directlone and acting patterns for various playe and rbles. The anin body consiets of the comparative expositions of eight playe, Including Taknsare (Takasago P1os Tree), Dojô11 (Dōjōj1 Tenple), Funa Benkel (Benke1 in the Bont), etc., wth explanatione of the eignificant points of the play, patterns for actins and nueic, roles and costunes, stage properties, etc." The Introductory section of the work concisely explains the lo-he-bru principle of noh, types of play, the noh stage, etc. The concluding section explains the different roles of actors and noh terme used In acting and dancing. A reference of highly profeselonal caliber for etaging noh performaces.

Kō no knbuk1 ke1fu

(Woh IInage of Rabuk1)

Minteuroto Ramomenteu

Tolsgo: Rikugeishe

316 p.

能 9 歌舞伎系譜

松本嶑松

六荟社 1956 。

Anta PN2924.5/.N6\%58

Commes on the noh elements and Influences which can be esen in the dancing patterns of knbukt playe. A comparative study of noh and kabukt performancee.

Hō no kenkyü

(Studies in Noh)

Ianal Kiyoniteu

Tokyo: Ofüsha

1167 p.
能9 研究

$$
\text { 金井清光 }
$$

㮃㮛杜 1969 。

This work first delves into the origin of noh as a divine ritual and traces its development with the changing times into a recreational art, a ceremontal art and then a cleselcal performing art, which ot111 ourvives to this day. Researches on noh plays, playwrighte and noh art theorias then follow. Encompaesing corroborative researches based on documentary sources and ethnological researches of parforming arte as practiced, this 1000-page book conducts comprehensive studies Into various aspecte of noh. Indexes of proper nanes, publications and playe are eppended. 古猿祭9籍已能9伝承

(Study of Noh: "Okina of Ancient Sarugaled and Tranonttel of Noh) Arat Touneysas 新井恒易 Tokyo: Shin Dokuchoshe 新談娄社 1966. 458 p. 111ue. Ale PAR2924.56.116A81

Comprised of three sections: evolutionary procese of okfon earugaku, texts of oklna earuraku and transenteal of noh. The firet section probes into the origin, elgnificance and evolution of okina (old man) 
NOR - GERERAI

performance of ancient aarugaku. The eecond eaction is devoted to vartous, provincial texts of okina and comparison with oktina of noh dram. The third section surveje vestiges of ancient noh as they et111 exiet in the provincial regione, particularly along the Tokal district of Shizuoke, Alchi prefectures, etc.

N6 no konjaku

(Woh, Past and Present)

Nonomura raizo

Tokgo: Hokuj1sha

能9今昔

271 p.

野々村成三

本耳社 1967.

The author, wo is a noted researcher, discusses the genealogical developments of various noh schools and introduces noh parformars, past and present, of various schools. Serves as a "Who's who" of the noh world.

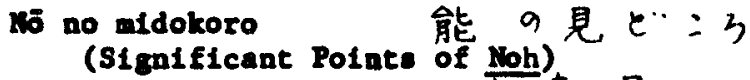

Makamor1 Shoso 市澘

Tokyo: Tamgava Daigaku Shuppanbu 王川大学出版部 1976.

244 p. 111 e.

Alia PA2924.5/N6125

Orientation guide for beginners. Takes up famous pieces fros the varlous categorles of noh playe (god play, battle piece, etc.) and denotes the "points to see" and "pointe to listen to" of each play. The author is a noh Instructor of the Kanze school.

25 no rok1sh1

(History of Noh)

Tobayachi Sek1

Tolyyo: Hiboncha

144 p. 111us.

能 9 有史

小林竞

头不社 1976 。

The author viatted and photogrephed rellc sites of noh and complied a booklet introducing the elted. Som of the photos are in color. Sites include Sado Is land (Mligata prefecture) were zeand was exiled, Iurokava (Ianagata prefecture) uhlch is famous for the provincial Rurokawa noh, Yanato (Mara prefecture), howe of Yannto serugaku, precursor of noh, ete.

531

wo no acteet

能の再生

(Rabirth of Boh)

Nogand Toyolchirö

Tokjo: Iwanaml \$hoten

351 p.

野上豊一郎

Aste RK2924.5/.216K6395 
MOH - GENERAL

A compilation of 12 treatiese on fundamental qualities, etage performances, 1deological thoughte, etc. concerning noh. The author 1. the same as for the followlug entry, 135 no rūgen to hand. Treatiece Include, "Woh Realise and Styllation," "Ghoet in Iloh," "Hoh and Japanese Ideology," "Translations of Hoh Texte," etc. These treat1ses had been previousis publisbed between 1931 and 1934 in varloue publications.

No no yügen to hana (Artistic Beauty and Flower of loh)

Nogant Toyoichirō

Tokyo: Imanand Shoten

303 p.

野上鲁一郎 岩波書店

A complation of nine treatises on bestc noh princtples, dietinguibins features of noh pleys, Ignificance of the velet (eupporting actor) role and peculiarities of noh make. The firet three treatises on yūgen (art1stic beauty), hane (flower or freshnees) and mononane (Initation or realian) propound zaand' theorles of noh and are the eseential princlples of noh art. These treatises had been publisbad between 1936 and 1942 in various monographs and pertodtcals.

Mo o aisuru (Tu Love Hob)

Masu Tatsusd

能专する

Tokyo: Wan'ya Shoten

那須辰造

198 p. 1llus.

わ年書店 1976 。 Anla PlR924.5/.116N38

A compilation of essaye by the author, who wa a scholar on French ilterature, concerning noh, a claselc perforning art that he loved.

Nö o atru hito ni

(For the Noh Viewers)

Kurtbayahi Telichl

Oeaka: Sokizenkan

227 p.
能导る人に

栗林貞一 箖善领 1939 .

A.1a PK2928.5/.M6R87

An Introductory gulde to noh, written elaply in question-and-anewer form, for the benefit of strictly amateurs. Written in 1946 iniediately after World War II. Couposed of three chaptere. Chepter 1 is titled, "Wight Before Noh Viewing" and explains the composition of noh plays, polnte to watch, etc. Chapter 2, titled "Day of Boh Viowing" Introduces representative noh, ehtent (Annce), broxen (contc Interlude) and utal (chant) pieces. Chapter 3, "ilight After Noh Viewing," expleine the noh playwight, neke, costumes, hand prope, etc. 
MOH - GENBRAL

$15 \overline{0}$ oyob1 kyōgen $k \overline{0}$ 能 及狂 言考

(Studise of 10h and Srōgen)

Hooda Yaouj1 本 田安次

Tolyo: Mrruoke Stuppamber出版部 1943.

278 p.

Alla P12924.5/.116865

Analytical studies of the characteristics of noh and kyōgen, Including vestiges of ennen noh et111 existing in varfous parts of Japan.

Studies of noh and brogen are contained in the firet section of tho book and Includes eseays on the "Ytyetery of the Mitror Roon," "Birth of Wakt lioh," "Appreciation of Kyösen," etc. The second eection titled, "Banen Meterfale, etc." and covere ennen noh as $1 \mathrm{textete}$ In Wt. Mnobu, Nikkō, etc, and different forne of noh dances remalning In northora Japan, Byikyuis, etc.

15 shōsola sen

能乵束挖

(Selection of woh Costume)

Kyoto Rokuritsu Hakubutsuken

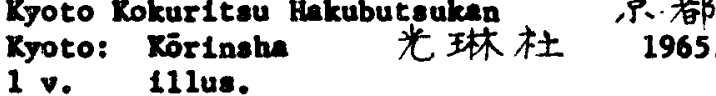

A compilation of 50 large-alzed photo 11luetrations, aning of color, of noh costumes displayed at the special exhibition of "lioh Mask and Costumes," at the Xyoto listional Huseum in the fall of 1964. Explanation of the photos and an article on transitione in noh costume are included. There 1s a short Bnglish explanation titled, "Noh Costums," at the end. An Bnglish "Liet of Plage" (photos) is also appended.

Nō to kabuks (Hoh and Eabuk1)

Romige Toyotale

Tokyo: Iwanani Shoten

332 p.
能と歌舞伎

小宫㮒隆 岩波荳店 1935 。 An1a P12924.5/.1161864

An analytical study of the fundanntal characteristice of noh and kebukt. Soh 1s studied mainly through zoant's theorles disected with teachings in Iolough ronge (The Actors' Analects).

Hö to Romparu (Hoh and Romparu)

Hiroes Yoshthiro Kyoto: Hateune Shob8 438 p. 111us.
能 と金春

広 瀨 瑞 弘 初音妻房

1969

Asta PK2924.5/.176 K48

Ralates the history of one of the noh schoole, the rowparu echool. Utilizing a wealth of hietorical materials, traces the 1200 yesrs of Romparu hietory--began as Yamato sarugalu, flouriahad as a noh school under the protection of Toyotont Hideyosht and Tokugava Ieyasu, served as a ceremonial art for the Tokugawa Shogunage and 
NOH - GERERAL

Survived through Mif1-Taishō perlods to the present day. Since zeant, the wain noh echool was kanse but prior to that, the maln form of noh wae the Yameto sarugalu performed prinarily by Koneru-za members at the Kanga ahrine, Kófukuj1 Temple in Yamato (liara prefecture). Therefore, the author claims that koaparu history is indispensable to the study of noh hietory.

Nō to kyōgen

(Woh and Byōgen)

Ranal Riyoultsu

Tokyo: Helj1 Shoin

668 p. 11lue.

$$
\begin{aligned}
& \text { 能と狂言 } \\
& \text { 金井清光 } \\
& \text { 明治畫院 }
\end{aligned}
$$

1977.

Ala PN2924.5/.N6K255

A study of the differences and sinllarities between noh and kyogen. The analysis is based on the author's theory that although noh and kyögen both originated as divine rituala (e.8., dances, conge, incantations, etc. praying for a rich crop harvest), which were performed by sarugaku actora, a difference in obclal otature developed. Those actors who played the roles of gods became noh perforwers while those who did not, became kyogen performers. Thus, the noh performers were considered to be of a higher rank than the kyogen performers.

(Woh and Folk Performing Arts)

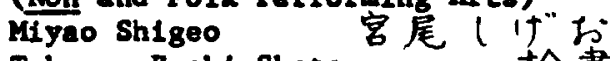

Tokyo: Enok1 Shoten 桧書佔 1967.

216 p. I11us.

As 1a G1695/.1559

Over 50 feativals, events, provincial noh kagura (Shintó music and dance), etc. throughout Japan are eurveyad in an attempt to discover, within the folk performing arts, the old form and developiantal processes of noh and uts1 (chant). Each performing art or event is explained. Cartoon-like eketches of popalar eppenl are Indluded. $A$ few of the eventa Introduced are rurolene noh (Yamgata prefecture), kojekama1 (Fukuoka prefecture), Mibu deinembuteu krogen (Ryoto), kund odori (Okinawa), etc. A study of folk performing arta as well as entertaining reading for the public.

能と能面9世界

(World of Noh and Boh Mares)

Maknimura Yasuo and Tasal sowe1

Kyoto: Tankóna

245 p. 111ue.

淡 交社

Intended so a beginner's guide to noh and noh anoks by the author whose father had been a maker of wake. The author cleins there are over 200 types of waks, If categorised in defa11, but that approxiantely 60 constitute the etandard types. In this work, noh anoke used in 39 plays, ascociated with famous noh sites in and around Kyoto, are 
NOH - GENBRAL

Introduced. In eddition to make, photos of etage scenes and the actual eltes are shown. Simple explantions of the playe are given to rouse interest of beginners. A supplementary work, with the save t1tle, covering noh eites throughout Japen, is ontered below. (D1scourse on Noh end Utal)

Amunuma Hōeon (Takah1ko) 328 p.

Intended to enewer various questions that beginnere wight have when viewing noh performances or learning to chant noh texts. Discusees the origin and historical developants of noh, conparioon with kabukl, rules and principles of utal (chant) and noh, etc.

Wōyō hyakumon hyakutō (Hoh and Utaf 100 Questions and 100 Anowers) Pujlahiro Trugio 城 継 夫 Tokyo: Wan'ya Shoten thや書店 1978.

An1a PN2924.5/.N6P845

A handbook, in question-and-anawer form, on noh and utel (chant). Providee imple, concise explanations, particularly on patterne set to oynchronize dancing and chanting on the stage. Also, conente on general toplcs such as "exile of zoand," Sagi school of krogen," etc.

Boyö zuseteu 能言䍃图説

(Illustrated Explanations of Iioh Texts)

Sanar1 Kantarō

Tokgo: Wijt Shoin

佐 成諒太郎

348 p. 111 .

明治春院 1948 。

Compriead of three parte. Part 1, "Woh Diagran," has 62 pages of color sketches of noh stage ecenes, weks, costures, hand props, ete. and serves as a reference for staging noh performances. Part 2, "Ganeral Rennice on loh," presente an over-all view with exphasis on history. Part 3, "Datailed Cowneste on Boh Texte," discueses the composition of noh texts and provides references on verses quoted in the texts. It cites nuserous quotes and their sources. Following the quoted verses are page numbers correnponding to those in the 6-volume Yolkyolu talken (Comprehensive Viow of Noh Texte) edited by the author.

Puj1shiro Taugio

Tolgo: Han'ya Shoten

140 p. 11lus.
写真 $2 ”$ 見了能の扮装

Costume)

菨城秤夫

$$
\text { わ人や害店 } 1979 \text { 。 }
$$

Ania GT1745/.J3P8 
NOH - GENERAI

With numerous photos and drawings, explains the costume for practically all of the noh perforwers, including costunes for old men, werriors, female demons, ghosts, etc. Through this handy references, noh costumes can be concretely understood.

Shin no no furusato 新・能 9 3、るさと

(Sites Associated with Yoh, New Edition)

Bd. by Asah1 Shimbunsha

Tokyo: 1964.

252 p. 11lus. Ale PK2924.5/.116A82

Through photos of sites, structures, etc. that gave birth to or are closely aroctiated with noh plays and photos of stage scenes, well-known noh plays are explained eimply as though in a travelog. Examples are: the play, Atoumori, and the scene is Sumanoura, Hyogo prefecture; Sumidagara (Sumida River), Tokyo; Ataka (Ataka Barrier Gate), Ataka town, Toyam prefecture, etc. An entertaining orientation guide to noh.

(Noh of Shōwa Pertod)

Okēch1 Tosh1teru

Tolyo: Wan'ya Shoten

453 p. 111us.

大河内俊辉 h人や書店 1965 .

Asie PN2924.5/.N654

A compilation of the autbor's commentaries divided into three main sections: personalities, noh comments and miscellaneous. These commentaries had been published between 1957 and 1964. The noh coments were published in the Tokro ShImbun and the others in periodicals. The author claims he placed personalities in the firet section because he wanted a photo, at the beginning of the book, of logucht Kaneouke who opened his eyes to noh. Part of the noh comments ere arranged chronologically but the intent is to provide an overall view of the noh world during the late 1950 s and early 1960s

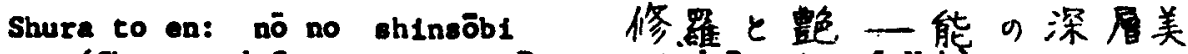
(Shura and Senoousness: Deep-rooted Besuty of $\mathrm{koh}$ )

Baba Akiko

Tokyo: Kōdansha

221 p. 111 lue.

$$
\text { 馬場古手社 }
$$

1977.

An analytical study of shura (Buddhist Realn for Dead Warriors) as represented in shuramono battle plece), the eecond act of a typical five-act noh drama, and en (sensousness) as dieplayed in katsuramono (femele w18 plece), the third act, and how these semingly contradictory facets blend to contribute to the aesthetic appreciation of noh. These are considered by the author to be fundamental virtues which made noh a profoundly moving art for over 600 yeare. 
Tōgaku1n- àma nógaku yokó (Noh Nemorabilla of Tögaku in)

Ed. by Yonezama Kongōka1

Yonezawa: 1974.

3 v. 111us.

A reproduction, in three volumes, of noh documentary mementos of Tögakuin (posthumous Buddhist nase), the 6 th lord of Yonazawa fief, Yamagta prefecture, Uesugi Shigasade (1720-1798). The three volumes consist of photo reproduction of documente, reprint of same in block characters, with explanatory notes added. Generations of the foudal lords of Yonezawa fief had been noted to love noh and valuable noh records had been preserved in the Uesugi family. Particularly, Tögabuin personslly cherished the longō school and received numerous sectet records from the head of Rongo famlly.
Yög1 ruijū 要技類從

(Classification of Essential Sk111s)

Mrita kōfū 森田光風

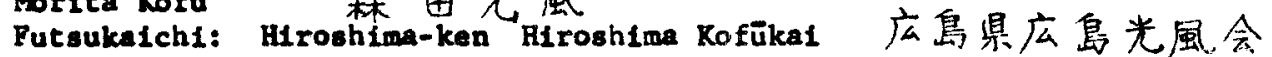
1961

1 v.

As 1a PN2924.5/.N6267

A detalled classification of noh masic, with abundant annotations and taging Instructions, coapiled by Morita kofū of the Morita school of noh fue-kata (flutists). Worita based his study and classification on old, authentic records, including secret books, records of once orally tranamitted informetion, etc. Examples of muscal sk1lls noted are de (stage entrance), nanor1-bue (selfintroductory flute), yobldasht (calling out), etc. Particular attentions given to the section on hayashi-mono (instrumental masic). Chapter 8 is devoted to explanations of hayaehl, mat (dance), at-kyogen (comic interlude), etc.

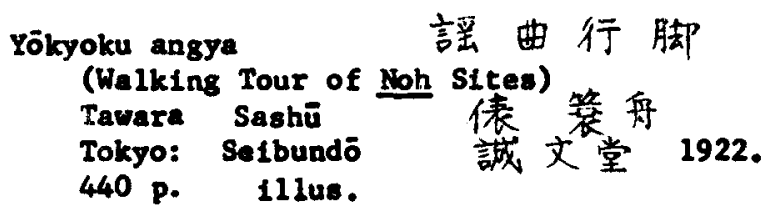

A guide, with explanations and photo illustrations, to famous historic sites noted in noh texts and performances. Discusses the affiliation of the sttes with noh dram.

Yôkyoku hêtkamonogatart $k 1 k o ̄$

(Noh Texts and Travelog of Tales of Helke)

Shirasu Kasako

Tokyo: Heibonsha

它汸正子

2 v. 111us.

謡曲・平家物語紀行

1973.

Asta PL724/.S55 
NOH - GENERAI

Written with the intent to reveal the close affinity between Hetke monogatar1 (Tales of Heike) and noh texte. Avolding a sholarly approsch, the euthor presents her explanations in the form of a travelog, in two voluses, with ample photo 1llustrations (both color and black-and-white) of famous aites noted in the texts. The author points out that over 40 or practically all of the shuremono (battle plece) of noh are besed on Tales of Heike and that most of the shuramono were written by zeami, who also composed kateuramono (fenele rig piece) from Tales of Heike. At the beginning of each volume, there are comparisons betwen noh plays and sections of the Tales of Elike and at the end, there is a chapter called "Course Guide," giving street and transportation directions to the historic sites.discussed.

Yôkyoku kyögen 言䍃曲・狂言

(Noh Drama and Classical Comedy)

Bd. by Nishio Minoru 西尾実編

Tokyo: Sanseidō 三香堂 1961 .

845 p. 111us. Asia R2735/.N58

Detalled studies in noh drama and kyögen (classical comedy) to show the extent of research already acoomplished and to delineate the remaining tasks for future research. Divided into noh and krogen sections, and for each the study begins with a survey of algnificant research materials available on the subject, then proceeds to scrutiny of reproduced research documents and their interpretations, and concludes with annotated bibliographles and pertinent miscellaneous materials. For the noh sudy, Zeant's writings are used whlle for kyögen study, Warambegusa of Okura Toraak1ra (1597-1662) 1s researched.

(Hoh Text8, Claseleal Comedy and Kadenoho) Bd. by Koyame Hirosh1 Tokyo: Kadokam Shoten 小山弘志編 1958.

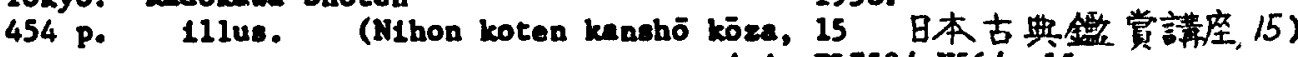
Asia PL753/.2856/v.15

Comprised of two main parts: evaluation of texts and "Window." The firat part is subdivided into noh texts. In whlch five plays are analyzed, krojgen (classical comedy), In which ix playe are taken up, and the Kadensho (Basic loh Principles), In which the author coments on Zeaml' noh theorles. The second part, "WIndow," discusses the or1gin of noh and kyōgen, beckground of Kannani and Zeami, Warambeguea and 1ts author, Okura Torakira (1597-1662), comparisons of noh and krōgen with kabuk1, etc.

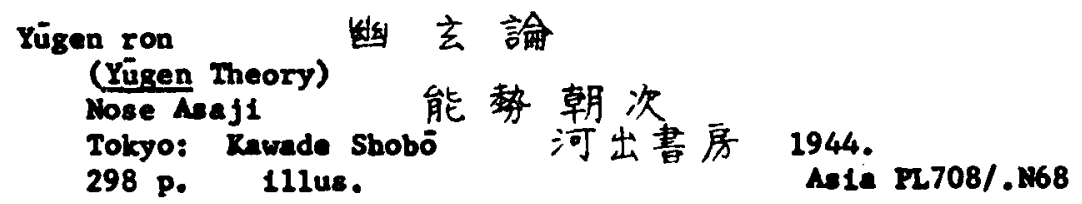


MOH - GENERAL

A study of the concept of yegen (artistic beauty) from the standpoints of wake poetry, linked verses and noh dram. Preceding the amalytical coments, there 1s a saneral discuseion of yigen, 1to origin and oveluation, eignificance es an artistic concept during the Middle Ages, etc. In the noh fleld, zeami' theory of güren, development of rigen beauty in pleys, Komparu Zenchiku's theory of rịgen, etc. are taken up.

Zoku nō no onote 続・能9 面

(Hoh Masks, Supplement)

Suzuk1 Reiun 鈴 木 糜雲

Tokyo: Wan'ya Shoten it

122 p. 111us. As 1a NB1310/.s9

Consists of two parts. In the first part, the author, who is a maker of noh maks, explains the various types of masks, epeclal features that are worth noting, art of making mask, etc. Photos and diagrame are used extensively. In the second part, 10 Horho echool mask, designated as Important Cultural Properties, are shom and doscribed in detall. This booklet serves as a reference which provides concrete information on noh masks.

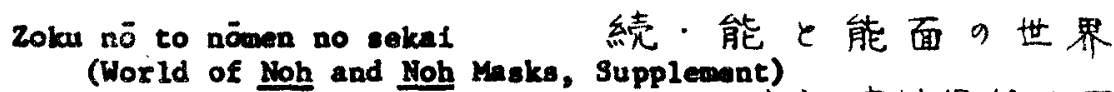

Hakamura Yasuo and Hatanabe K1yoj1 本文.中村保雄; 军真浜迅喜代治

Kyoto: Tankoshe

236 p. 111us.

As1a PW2924.5/.N623/supple

A supplement to the above-11sted work by the sane title, No to nowen no seka1. In the previous book, only noh eltes in kyoto and vicinity were shown but in this work, 34 plays, associated with famous noh sites throughout Japan, were chosen. Selectlons were based on the types of make the author wanted to present. As previously, photos of mask, stage ecenes and actual altes of noh plays are given, together with simple explanetions of the plays. In addition, this work contains, as appandices, annotated charts of basic noh plays and maks, and an illustrated explanation of a noh stage. 
NOH WRITERS AND PERFORARR

558
Dogen to Zoams: 世阿洂

chūes chuั 中 (Dogen and Zeami: Seeking the Fountainhead of Middle Ages)

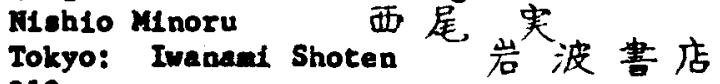
310 p.

1966. Anta PL1473/.D6A58

A compliation of 19 treatises, published between Apri1 1950 and Deceuber 1965, on Dogen (1200-1253), founder of Buddhist sot8 eect, and Zeami Kotok1yo (1363-1443), who firmly established noh as an art form. The author tries to trace and evaluate the contributions of Dogen and his religlous thoughts to the art and 1iterary form of the Midle Ages. He also describes and appraises zeani's noh theories and their Impact on the literature of his period.

Füshi knden 風姿花伝

(Besle Yoh Principles)

Zeand [世阿弥] Bd. by Nogani Toyoichiro and Mishlo Minoru 野上曹二郎。西尾実校訂

Tokyo: Imanami Shoten. 岩波害店 1958.

125 p. Asle PL792/.S4K3/1958

Consists of seven articles, written by zeani Notokiyo (1363-1443), to preserve the secrets of the noh art developed by the Kanze chool. zeani's books were witten with the aim of paseing on what he has learned from his father, Rannani Kiyoteugu (1333-1384), to posterity. The third art1c1e, Yondo to to (Questiona/Answers on loh Principles) was written 1n 1400; the fifth, Ogg (Hob Basics) in 1402; and the seventb, Besahi kuden (Supplemental Verbal Teachinge) in 1418. Contains explenatory footnotes and to facilitate comprohenalon, hiregene readinge, punctuation anke, etc. are given. An Index of words and pharases is appended.

Püßh1 kaden zenshaku

最姿萧伝全䣋 (Basic Noh Principles, with Annotations) Zeend [世阿弥] Ichimare Bfroghi Tokyo: Töhō Shobō 束宝書序 1958. 227 p. Ala PL792/S4/1958

Zeand's work, Füahl kaden (Bastc Moh Principles), with definttions of words and phrases, Interpretative explanati ons of taxt and upplemental coments on bistorical circunstances of the parlod. Delves into detalls of each of the seven articles. Articles not cited in the preceding work lnclude the f1rst, Benral keilso fo (Age and Training); second, Honcmane if (Intention); fourth, Shingt (Hiletorical Developant of Sarugaku); and elxth, Eaghũ (Flowror Learning). Also Included are part: of Zonen': Eakyó (Flower Mirror), and general cownents on noh, including its hietorical developent, play compostion and performaces, noh texts and noh byögen (comlc Interludes). 
BOU TRITBRS AND PERFOMYGRS

561

Cal no michi hito no atchl

芸の道・人の道

(Way of Art, Way of LIfo)

Konds Kanso 近藤 乾三

Tokyo: J1yi Gandelsha 自由瑅代社 1977.

$245 \mathrm{p}$.

As 1a PI2928/.1565A29

The author, Kondō Kansō (1890-), a shlte actor (protagoniet) of the Höshö school and a designated (human national treasure), telke about his noh parformances and recollects his mentor, Höahö kurö (1837-1917). Performances discussed Include Ragekiro, Kiyoteune, Shunkan, etc. Apponded are a colloction of his halku poese and life chronology.

Hane to yūgen no seka1: zeani 花上幽云9世界 (World of Plower and Artlet1c Beauty: Zeans) Shlrasu Masako 白 Tokgo: Hobunken 宝文館 1964.

194 p. 111as. Alla $\mathbf{T L 7 9 2 / . 3 4 2 8 8 2}$

Takes up the essential qualities of noh performance techniques as pointed out by zoand (1363-1443) in his writings. Coments on the qualitles that bring out the true characteristice of noh ert. Perforning qualitles diecuesed include hane (flower or froshnese).

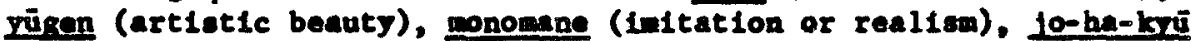
principle (Introductory, dovelopantal and climetic stages), etc.

Hiroatch1 böoku 博通望憶

(Becollections of Hironichl)

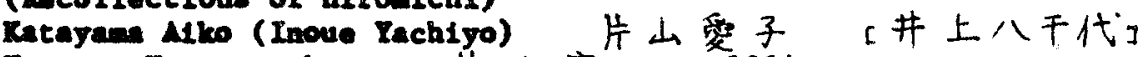

Iyoto: Rateram-ke 片 du 家 1964.

101 p. 11lus.

Ala PL2928/.R3I56

In anory of Rntayam Hiromlch1 (1907-1963), a noted parformer of the Tanse school, his tenliy pablished a private edition dedfceted to recollections of his life and stage performences. Includes many photographe, a blographical eccount and a chronology of his stage apperances. (Blower Mirror, Utal Secret Bacorde)

Zeand [世世阿弥] Bd, by Wageda Dalgala Engek1 Hakubuteukan 早稻由大学演教博物館編

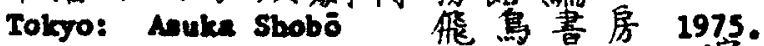

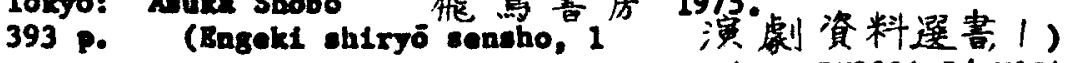


NOH WRITERS AID PERTOMERS

Reproductions of two of poh writinge by zoand Motokiyo (1363-1443). Kalro (Plowr Mirror) and Dtel hidenebo (Utal Sacret Bocords) are

first show as photo reproductions In celligraphy and then as reprints In block cheracters. Brief explanatory notes are given in beadnotes and bibllographic notation are given at the end of the book. There are no Interpretative coments on elthar work. The original enuscripte wre formerly in the Yasude collection and are now deposited In the Waseda Univereity Dreme Huseun.

Kanesuke geldan 兼资荟談

(Art Talke of Kaneouke)

Noguchl Innesuke

Tokyo: Wan'ya Shoten

206 P.

野口萧资

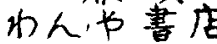

1953.

Asia PIR924.5/.36m63

The author, Nogucht Innasule (1879-1953), who bad performad the role of shite (min actor) as a past meter of the Bosho school, talke about his art. Touches upon such subjects as artistry in noh performences, Banke of roles and proper attitudes to anintaln when performing them, hints on how to learn noh chants, mesic and dance patterna, etc.

Kannand to zeand

(rinnual and zeand)

Tolda Michisō

暒顾际と世阿弥

Tokyo: Irranant Shoten 岩波書首

205 p.

岩波書店 1969 。

An1a PW2928/. T3T6

A comprehens 1ve, eubjective study of the two great orlginators of noh dram, Innnent (1333-1386) and his son, 2aand (1363-1443). The author andjees the living pattern, the respetive role in noh histors and the rritings and actions of each. He tries to explain their olntlaritied and differences in the light of the turbulent historleal clrcumstances surrounding Nambokuchö (Parlod of Northern and Southern Dyanctes) wich affected their ilves.

Ita Roppelta (Kite Roppeita)

Osada Golkyō

喜多六平多

奏由午狂

Tokso: Re1ju Kinon Shuppan kita Roppeita Bakkojo 米寿記余 出版真多六平多登行所 1962.

103 p. 111us.

Asta FO PLR928/. 555682

Publiahed to celobrate the bel fu (88th blrthdey) of Kita Roppeite (1874-1971), the 14th head of the Kita school of noh drama. Comprised alnly of photographe of his atage appearances and life activities. Also Includes his recollections and art talke. A chronologs of his performances and accomplishants is appanded. Defor to Boppelte geidan (Art Talke of Roppaita) cited below. 
NOH WRITERS AND PERFORMRES

Kōchū Kakga

(Flower Mrrow with Appendices)

zoand [世阿弥] Bd. by Kewae

Tolsyo: Wan'ya Shoten

86 p.
校注花獍附

Revase razuma
巾人, 龺店
至花道九位

川濑一馬校注

As 1. PL792/.54T38

Beproduction, In block characters ofth hiragena readinge of zeanl's Raksd (Plower Mirror), Shileado (Plower Passway) and Kril abods no shidal (Hine Bold Learnins Stepe). Explanatory renerke are presented in the headnotes and interpretative commnte on each work are given In the introduction. Whereas Iüht keden (Baulc Woh Principles) contained Tennami's ideas, Kakso represents Zaand's own overall viewe regerding noh performances.

Köchü nōsakusho

校注能作書

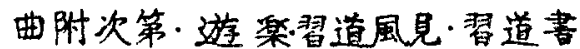
(Noh Playwriting)

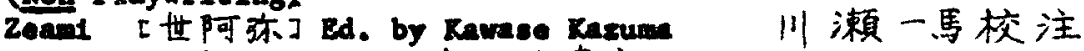
Tokyo: Wan'ya shoten h人, 書店 1965. 75 p.

As1a PL792/.S4A6

Reproductions, in block charecters with hlragena readings, of zeani's Mogakulho (Woh Playriting), Ryoluzuke shidal (Tuning Stepa), Moraka shüdo Fuken (Woh Ph1losophical Outlook) and Shudosho (D1rections to Noh Participants). Explanatory comenta are given In the headnotes and annotative remarke on each work are noted in the introduction. Mosakusho reveals that zeand furthor refined the concept of wisen (artistlc beauty), first advocated by lannand as a noh art form. Shüdöaho polnte out the lmportance of the entire cest to act In unison to assist the shite (protagonlat) in puttins on a splonded porformance.

Iōchü Zeand jürolasbuabü 校註世阿弥十六部集 (Annotated Collection of Zeani's Sixteen Books) Zasme [世阿弥] Bd, by Noncmara Ka1=o Tolso:

AnIa FL792/.S4A16/1926

Of Zeand's witings, this work is an annotated collection of reprinte of sixteen books belleved to have been copled during the early Bdo perlod. Includes ateple beadnotes. Considered to be prinary source material on atudy of noh. (Directory of Performers of Four Theaters) Ranee Kotonobu短世元信了 Bd. by Tanaka Mitoura 由中充编 Tokyo: Wan'ya shoten th力p害店 1975 . 348 p. 11lue. (Nögaku ob1ryō, 6

能染史料，6) Alia Raf. PNR924.5/.116K64 
NOH WRITERS AND PERPOMRES

A directory of performers of the four Yemato Serugaku Woh theaters,

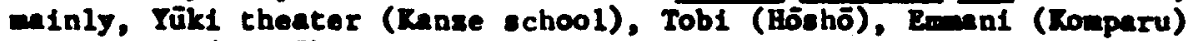
and Salnto (Kongō). Contains briaf blographies and anecdotes. Covers the reichö to early Bdo perlod (1596 to early 17th century). As a biographical dictionary, constitutes a significant docunent for research on noh history. Reproduction of the work, authored in 1646, by Kanse Shoemon Kotonobu.

Kompary kodensho shūsel 金春古儫書集成

(Collection of Ancient Writinge Tranomited in Tomparu Panily)

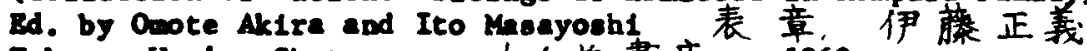
Tokgo: Wan'ya Shoten わhや書店 1969. 712 p. 111 us. Aasa $82675 / 765$

Reproductions, In block printing, of anclent writinge transaltted for generations in the Tomparu fandly. Consists of approxinately 45 Items written by nembers of the romparu fanly or theater. Writings are divided Into four main divietone Tomaru Zenchiku (1405-1470?), Komparu 2 empo (1454-?), Romparu theater and Komperurelated historical materials. Definitions and explanations of words and terms in the texts are given in headnotes. An introductory section provides the historical backgroud of the rritinge and their trananttal, brief blographies of prominent family and theater f1gures, etc. The appendices contaln genealogical charte, reproductions of Ignatures, chronology of the Romparu thester developmente, etc. Includes detalled ladexes by personalities, playe, worde, pharases, etc. Of reference value to researchers. (Study of Woh Thoortes) kontoht Jin'teh1 Tokyo: Bnnawa Shobō 324 p. 111ue. 能楽論研究

$$
\text { 小西査一 }
$$

1961. Al1. P12924.5/.205765

Interprets and comente on the theories of noh drem and performances expounded in the writings of zaant (1363-1443) and his eon-1n-1aw, Touparu Zenchiku (1405-1470?). There are reportedly 21 recogalaed

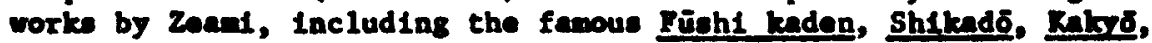
etc. Zanchilu is also credited with 21 works. Beceuse of his close relation, Zanchlle followed in the footatepe of 2oand, Inheriting the etyle of rigen (artistic beauty) and nononnes (initation), and also showed special talents in thooretical studies and writinge. 世阿弥二中世文化 9 苚边

(2eand and Formation of Bob: Cultural sttuntion of the Middle Ages) Coto Hajtere Tokyo: Hokuj1sha 後萿 淑 299 p. 11lus. 木耳社
1966.

Ale PAR924.5/.36668 
WOH WRTERS AND IERPORMRS

Searches for Indications of popular, public appeal of noh during the Randicura (1192-1333) and Murowncht (1393-1573) periode. Bxemines Ite precuraors, sarugalu and denraku, for tholr contributions to. developant of noh. The latter belf of the book 18 deroted to the study of zeand, his life and artistry as noh performer and theorise.

13 shashin no geijutsu 能. 捨心9 芸術

(Hoh, the Art of Self-Abandonient)

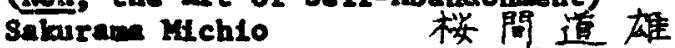

Tokyo: Aashl ShImbunsha 1972.

335 p. 11lue. Ale RH2924.5/.N6 S26

Autoblographical account, recollection and art talks of the author, Sakuram Mch1o, who 1s a noh performer of the Nomparu school. Bolates that the highest stage of the art is reached when the parformer discards his self-interests. Lot a question of technical sk111, artiatic parfection is attalned then the perforear can dance and ing in a state of complete self-abandonwent.

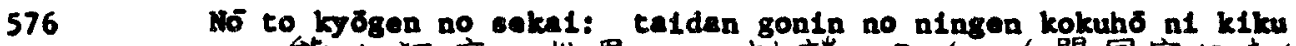
能と狂言の世界—刘談五人9人間国宝にきく (The World of Sh and Srogen: Interviews with Flve "Living Nationel Treasures") Ed. by Yokomicht Mar10

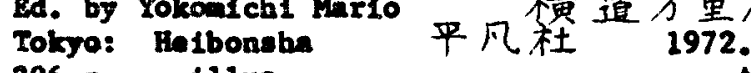
296 P. Ll1us. Ale RN2924.5/.X686

A complation of interviewe with five famous, elderly performore (considered by the Government es "Living Nationel Treasures") of noh and krōren. The five Interviewees are: Kondō Kansō (ahtte or protagonist of Bōshö school); 15 Yoshlmiteu (sma11 hand dra artiat, head of 15 school); Kakinoto Toyoj1 (large hand drua artiat of Komparu echool); Nomara Manzó (brögen performar of Iruad schoo 1); and Mintsumoto Kanzö (rak1 or supporting actor of Höshō school). Interviews touch on subjects of interest to posterity. such a their training, perforwances, thentrical experiences, etc.

Nōyō ahlnkö: Zeand ni terasn 能言䍃新考一世阿弥に照らす (10w Thoughts on Woh: Pocus on Zeand) Bōeal Teutora 香 西精 Tokgo: Hinok1 Shoten 桧書店 1972 . 426 p. 111 us. Ae1a PL792/.54274

$A$ coupliation of over 50 research treatises and agazine articles on noh written by the author over a pariod of 35 yeara. Basical1y, the work can be divided Into a etudy of zeand and an antyels of his works. The book contalns the following five maln sections: 2aan' 'v vewe on noh; analyels of playrrighte and their works; utudy of zeaud's playe; round-table discussion on zeand 's nob; and relationshlp betwen noh and tea ceremony, calligraphy and zen Eaditations. 
WOH WRIIBRS AND TERTODASS

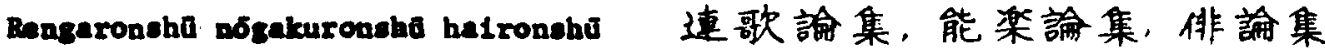
(Collections of Theoretical Comentaries on Linked Verses, Woh and Ha1ku Poetry)

Bd. by Ichijl Toteuo, Onote Akira and Turijonn Bichi 伊地知 鉄男，表章，栗山理一校注・䚿 Tokyo: 8hogakcen 小学館 1973.

619 p. (Nihon koten bungalu zenohū, 51 日本古典文学全集，51)

An1a PL753/.0157/v.51

Coneiste of three sections, two on poetry and one on woh. The noh section Includes five representative works by zead (1363-1443): Fühl kaden (Basic Hoh Principles), Kalso (Flower Mirror), Shlkadd (Flower Pathway), Sando (Three Paths) and Shugrokn tokuke (Flover scquisition). Annotations, explanatory headnotes and conversational atyle of the tert accompany each article.

RLnchũ bemmonshū 隣忠見聞集

(Coupllation of Obeervations and Experiences of Btnchu)

Tokeda Chikatada (RIncha) 德田隣忠.

Bd. by Sakneoto Setchs 扳本雪鳥編

Tokyo: Wan'ya Shoten わhや专店岛 1972.

143 p. (Nogaku shiryo, 2 能菜史料，2)

Ala PJ2924.5/.1562644

An Inside story of observations and epleodes of Tokuda Chikatada (1679-1760?), a noh performer who wa once under the patronage of the Kishd clan. Chilkateda's account covers the varlous noh schools during the aid-sdo period when noh was at the helght of its popularity.

580

Boppatte gotdan 六平太芸談

(Art Talke by Rite Boppeite)

Kita Roppeita

Tolso: Kofüsha

317 p. 111 .

喜多六平太

光風社 1965.

A eollection of obeervations and comentaries by Xita Roppeita XIV (1874-), bead of the Kita school of poh drame. The collection constets primerily of his talks on noh roles and performaces but also includes criticien on training and practices and recollection of his fawous predecessors. 
WOB WRITERS AND PERPORERS

A compilation of 12 new noh pleys by the poet, Toki zemaro (1885-) Plays include Iunedono, Shinran, Apostle Paul, etc. For each play, cources and explanations are given. Mdditionally, performance dates and places, drane reviews and comentarles by the playsight himeelf are Included. Firet performances were given aninly by kita Hinorr (1900-), protagoniat of kita school of noh dram.

582

583

584
Tōchü Zeani ni jūeambuahū (Zeand's Twenty-three Worke wth Headnotes)

2eanl $[$ 世阿弥] Bd. by Kawace Kasum

Tokyo: Mogalaseha 能案社

1945.

364 P.

Ae1a PL792/.\$4/1945

Revised and edited reprinte of 23 zeand's wrke. Headnotes are included. At the beginning of the book, annotations of various works, Iffe and chronology of zeant, etc. are presented. Indexes of personalities, playe and phreses are given at the end. One of the indispensable basic sources for study of zoand's rritinge.

Toyotakn nikk1

(Toyotake Diary)

Bujlta Toyotaka \&落田曹高了

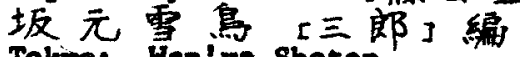
Tokyo: Wan'ye Shoten

171 p. (Nögalu oh1ryō, 3

$$
\text { 豊高 日記 }
$$

Rd. by Sakanoto Satcho (Saburo)

A.1. PN2924.5/..65884

A chronologtenl record epanning 58 yeare between Genroku and hōrekt perlode (1688-1763), of the training undergone by Fuflta Toyotake (1686?-1776), deuteragonist of the Shunto (waki-knta echool of noh drana).

Uta1 rokujünen: Sh1seteu oboegaki jたい六十年一紫雪らうる”之書 (S1xty Years of Boh Chanting: raporandum of Shiseteú) Pujinanl Shleeteu 藤波紫雪 Tokjo: Hinoks Shoten 棯曺店 1977 . 301 p. 111ue. Asia $\mathbf{L} 4420 / . \mathbf{F 8 9 2 A 3 / 1 9 7 7}$

Art talk and recollection of the author, Fuflneat Shlecten (1897-), who spont his entire lifetine as an chorus chanter of the lanea school. The book was written on the auspletous occeston of his 77 th birthday and golden wading anniversary.

Yökyoks sakuaba no kenkyā (Studies of bh witers)

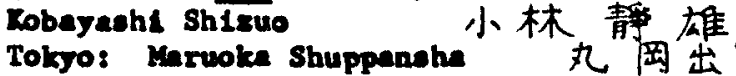
言䍃曲作者 9研究 294 p.

Alia PH2924.5/.M5X62 
IOH WRITERS AND PRRFORERS

Blographical compllations and reseerch analys is of the works and styles of the following elght noh writere: Kannand, Zeami, Komparu Zenchlku, Konparu zempō, Kanse Nobunteu, Kanze Nagatosh1, Miyanagu and Takeda Jose1. A scholarly and evaluative study presenting baslc cource anteriele on noh writere.

Zeami 世阿弥

Kobayasht Shizuo

Tokyo: Hinok1 Shoten

252 p.
小林青弾雄

桧書店 1943 .

As1e PL792/.54275

A research treatise on zeanl. Divided into two eections, with the flrot covaring the charecter and art theorles of zeant and the second, the eccomplishwont of zeanl.

世阿弥

$$
\begin{aligned}
& \text { Sakaguch1 Gansho 青悟堂 际去草 } \\
& 256 \text { p. Ale FL792/.S4288 }
\end{aligned}
$$

Written with the intent to describe a noh text and to depict the - ignificant values of zeani. Comprised of two chapters:

"Zeani and His Times," and "Zeani and His Works."

Zeam1 世阿 弥

$$
\text { Takdgawe Shun 滰 11駿 }
$$

Tokyo: De1gaku Shobō 大学書痛 1961. 249 p.

Ao1e F2839/.A58384

A blography of zeand tho wes considered a genlus of the noh arts. Falthfully pureulag historieal materials, the account tries to pleture zeand within the context of tho hiotorical and coctal clrcuneterites of h1s tires. Patterned after the porforannce cequences of noh dram, zeand's life is divided and portrayed accordins to the 10-ha-bri (Introduction, development and clinax) principle.

山崎 正和

河出書原 1964 .

200 p. $111 \mathrm{us}$. 
MOR WRITER AND PRRTORARR

Contalns two dranatic pleje, zeand and Karute no shiro. Tanagaki

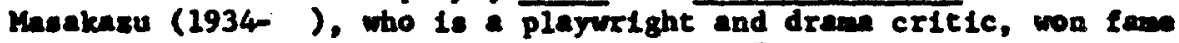
wen zeanl was firat perforand at the Hefyüse theeter in soptember 1963.

590

Zeami 世阿 弥

Bd. by Yamazaks Masakasu 山 㥓 正和编

Tokyo: Chūō xōronaha 中央公椧杜 1969 .

478 p. Illus. (Nihon no 1 cho, 10 日本9名著，10)

An1a PN2924.5/.06S42

A collection of zean' a noh theorles Including Füht kaden (Basic Hoh Principles), Ralyó (Flower kirror), atc. In this work, the original texts are translated into conversation form to facilitate reading. For beginners, an orlentation article eltled, "Imvitation to Noh," Is Included at the end.

591

Zeant Basho Bakin (Zeant, Bashō, Bak1n) Furukave Hiseonl Tokyo: Fukumura Shuppen 褔村出版 1967. 233 p. Anta R2715/.887

A collection of treatises on the three witers mentioned in the t1tle. There 1s no them running through the collection.

Zeami ge1jutsu ronshü (Compliation of zeami' Art Theories) zeand [世阿弥] Ed, by Tanaka Tü Tokyo: Shinchōehn 新潮社 1976 . 306 p.

世阿弥芸術猃集

A compliation of five representative witinge transalted by zeand. Containe mrginal notes and headnotes.

Zeane: hank to yügen no sekat 世阿弥—花と幽去9世界 (Zeand: World of Flower and Artietic Beauty)

Shiresu Manako 白州正子

Tokyo: Hobunken 宝文领 1970 .

194 P.

An1a FL792/.S42885

An exact replica of the aforementionad 1964 edition, titled "Hane to yügan no seke1: Zeand" (World of Plower and Artiet1c Beauty: Zeend). 
MOH WRITERS AID PERPODMERS

zeand jlhiteu denshoehü

世阿弥自䒹伝書栔

(Collection of Zeant' A Autographic Works)

zeand [ 世阿弥] $\mathrm{Ed}$. by rawese Razuna

Tokyo: Wan'ya shoten th

1943.

265 P.

Asla $21792 / .8446$

A collection of reprinte, with explenatione, of Zeant's worke deposited In the Hozanj1 Temple, Mt. Ikom, Mara prefecture.

(zeaml's Sixteen Booke)

Zeani c世阿弥, Ed. by Kon1eht J1n'1ch1 小西甚一編

Tokyo: Kawade Shobō 河出書后 1955.

201 P. (Genda1go yaku Mihon koten bungaku senehü 現代語訳

日本古典丈学全基)

A prove vereion of zeam 's sixteen books. Explanntory combenta on zeani' noh theories are appended. The dietinguishing feature of this work 1. the effort to avold technical terminology and to use eimple language throughout, both in the conversational vereion of the text and annotations.

Zean jūrolabuahū hyosshake

世阿弥十六部集評秋

(zeain' 's S1xteen Booke with Detalled Annotationo)

zaand [世阿弥了

Tokyo: Iranaml Shoten

Ed. by Nose Asej1

岩波砉店

能朝朝次编

2 v.

Ane PL792/.84/1963

Basy-to-read reprinte of nearly all of zean's works. The various texts have trenslations to conversational otyle, glosearies of terms and critical coments. Primery source anterials on noh dram and one of the Indispaneable beste references for etudy of zeand's writinge.

zeand kenisyi

(Study of zeani)

Hisht Razuyosh1

Tokgo: Sarubla Shuppan

234 p.
世阿弥研究

$$
\begin{aligned}
& \text { 西 一祥 } \\
& \text { †3 } 3 \text { 出版 } 1967 . \\
& \text { Asla PL792/.84278 }
\end{aligned}
$$

Divided Into two sections. The firet section consiote of five research trentises on zeant published by the author in poriodicala during the 5-year partod between Mry 1960. and June 1965. The eecond aection 1s ande up of annotated research booke on zeand and general Index of documents, and Includes a collection of monographs, perlodicals, nowapar articles, papplete, etc. published between 1898 and 1965. Arranged chronological1y. Index 1o useful as reference for research materials on zeant. 
DOR WRITERS AND PERPOMGRS

598

599

600

601

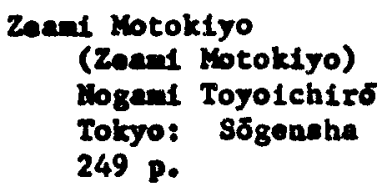

As 1a PN2924:5/.N6N6394

$A$ book on the I1fe, thoughts, noh theories, etc. of zaand Hotokiyo.

Zeani no nōgetron (Zeant" Theorles on $\mathrm{Hoh}$ ) Nish1o Mnoru 西尾实 Tokyo: Iwanand Shoten 岩波書店 1969.

504 P. Ale RL792/.S4279

A collection of treatises by an author who publlohed over 80 reserech ltene on Zeami betwen 1919 and 1968. A chronologicel listins of the publicatione is appended. Th1 work to comprised of three divisione. The firet is the author's general sumation of his zead research t1tled, "The Personage and Artletry of zeand." The aecond divielon contaln 13 treatises publiabed in early Shöre period, and the third includes seven recent articles.

20am1 sh1nkö 世阿弥新考

(kaw Thoughts on Zeant)

rösa1 Toutoms 意西精

Tokyo: Hen'ya Shoten 的人毒店 1967.

345 p. $111 \mathrm{las}$.

Ala PL792/.54276

The author's personel interpretations which run counter to the hitherto-held, comonly-eccepted views regarding zeand. A compilation of articles poblished in the parlodicale, Bungaku and Bbehs.

Zeant to nō no kokoro (zeant and the Spirit of Noh) ShInke1 Magefuse. Tolsyo: Hnokd Shoten 231 p. 桧赛佔

1978. Ale Pi2924.5/..6548

Diecusees the Influences of philosophy and religion on the ertietry of zeant. In reing himelf in Zen Buddh1on, Zoant cultiveted deep and profound eplritual experiences out of which he developed and refined hie elgnifleant concepte of yagen (artistic beauty), hane (flower or freshneas), kurel (art levels), otc. 
MOH WRITERS AND FERPORYRES

602

$$
\begin{aligned}
& \text { zeani to no no tankgū 世阿弥と能の探究 } \\
& \text { (Zeand and Probe Into Noh) } \\
& \text { Metsuda Tanoteu 松田存 } \\
& \text { Tokyo: Shin Dokuehooha 新䛃書社 } 1972 . \\
& 243 \text { p. 111ue. }
\end{aligned}
$$

Divided Into two eections. The first 10 "During the Formation of Ith Drame" and the second, "Outlook of Plays." The first section considers Zeavi' ert theorles using his writings, Fühht lenden (Basic Joh Principles) and Fakyo (Flower Mirror) as the basis. The second consiste of reproductions of 15 ehort erticles on plays which had been published in noh magasinee, euch ranie, Komparu, etc. Appended 1s a chart concelved by the author presenting hietoricel and background data on 250 noh playe preaently being performed. New plays written after Ne1ji period are excluded from the chart. (Zeand and Rikyū: Kuwata Tadachika Tokyo: Shtbundō 204 p.

世阿弥と利久—能祭と茶道 桑田忠新 至丈堂心栭1956。

Zeami (1363-1443) established noh as a way of art whlle Rikgü (1521-1591) eatablished ten cerenony ac a cultural form. Although both lived during different ages and cultural perlode, with zeanl during the Kitayame and Rikyü during the Aruchi-Honoyase, they had much in common. This work portrays the 11ves, cheracters and cultural accomplishments of both. 
Höahōryū yökyoku shöhon fush1 atauka1: Talshō ka1han 宝生流謡曲正本節报U一次正改版一 (Hoshō School Noh Text Musical Annotatione)

Tokyo: Wan'ya Shoten h九畫店 1921. 42 p.

As 1a PL735/.H68

Bxplains the basic types of fusht (tune or 1ntonation) used in the Hosho school of noh chanting or ainging. Gives instructions on how to chant or ing the basic fushi. Explains the various mustcal symbols used in the texts. (Hōshō Original Texts: Hōshō Shigehide Tokyo: Wan'ya Shoten

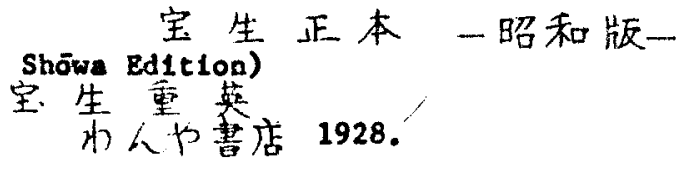
$37 \mathrm{v}$.

A collection, in 37 volumes, of Hosho Bchool noh text of approximately 185 plays. Text are reprinted, in calligraphy on rice pager, with stage directions for performere, instructions on pal (dance) and mustcal notations and symbole for utal (chant or song). The playe. performers" roles, mal and utal directions, otc. are explained in the Hösho shohon Shôra-ban kaisetsu (Höho Original Texts: Showa Edition Explanations). Preceding the text of each of the five plays in a volume are the syopos 18 and the required costumes and atage properties. Plays are generally arranged lo each volume as in an actual noh program. (Hōshō Orıginal Texts: Shōve Edition Explanations) Ejima Ihe1 江鼠伊兵徫

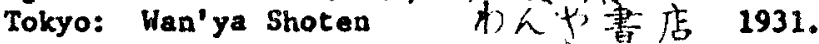
3 v.

Presents explenations, in 3 volumes, of the Hosho noh texte in the 37-volume edition described above. Vol. 1 discusea etructural composition of plays and arrangement of the 5 plays in each volume, roles and ranks of performers, descriptions of and inetructions on as (dance) and explanations of the musical notations on utal (chant oo cong) in the texts. Discusses Vol. 1 of the 37-volune series, as an example in play arrangement conforaing to an actual noh program. Begine with Takagego (Talacago PIne Tree), whi or kell noh (God play); followed by Tanara, shura noh (battle plece); Yuya, katsure noh (female-w1g plece); Hento, kyojo mono (mad vonin piece); and ende with Uleal (Comorant Fisherman), klri noh (concluding, euperhuman plece). Vole. 2 and 3 are malnig devoted to explanations of muelcal symbols for utal in the original texts. 
MOH TRXTS AND SCRIPTS

607

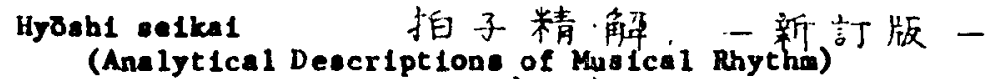

Mi yake Kötchi

Tokyo: Shüelsha 1977.

281 p.

As 1a PN2924.5/.U8M58

A aulcal analyols of noh texts which serve se the musical scores of utal (chant or oong). Bxplaine that utal 1s made up of the two elements of fusht (molody or intonation) and ma (rhythm) and that hrosh1 10 essentially the rhythmical pattern of utal. Musical symbols such as dots, lines, numerals, otc. are used to specify the rhythelcal pattern.

608

Ra1chü yökyoku senshü

解註謡曲全杗

(Coaplete Works of Noh Texts with Bxplanatory Hotes)

blogand Toyolch1ro

Tokgo: Chũo Koronsha

中央公論社。

6 v. $111 u s$.

As 1. PL 7651.164

A collection, In six volumes, of the 238 noh plays being performed at the tiac of publication (1935-1936). Plays are divided into the five fundamental typos: wak1 no mono (firat play), shura mono (second), katsura eono (third), zatsu mono (fourth) and kiri no mono (fifth and last). Plays are performed by the six noh schools of Kanze, Hosho, Komparu, Kongo, Kita and linewaka. Of the total of 238 plays, 130 pleces were being performed by two or wore schools. Each play 1s preceded by explanatory notes on type, playright, oynope18, principal and supporting rolea, etc. Texts have tage directlons and cerve as etage scripts. Pootnotes have also been added.

Kōchū yōkyoku sōaho 校言主㜔曲丵書 (Collection of Edited and Annotated Noh Texts) Bd. by Haga Ya1ch1 and Sasaki Nobutauna 侂々木停细编 Tokyo: Hekubunkan 2 v.

$$
\text { 博文館 } 1914 \text { 。 }
$$

A collection, in three volumes (Note: Aala Collection, Univerafty of Hawril has only Vole. I and 2), of edited noh texts with headnote annotations. Texts are lntended for reading pleasure and not for ataging performaces. Pleys ere erranged in Japanese eyllablc order and Vole. 1 and 2 contain 357 playe. Playe not currently performed are elso lncluded. Vol. 1 contalne the ceremonial, Introductory play, Oklne (O1d Minn), compoeed of three dances, one of which is sambado (Three Peasente) of kydren repertolre.

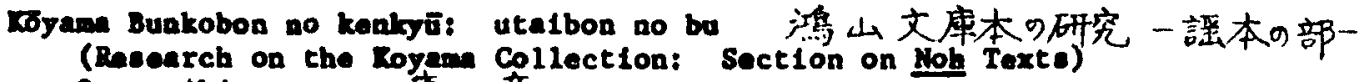
Orote Akira

Tokyo: Wan'ya Shoten

902 p. $111 \mathrm{ue}$. 章

$$
\text { A) 人, 他热店 } 1965 \text {. }
$$
Aala IL735/.045 
WOH TEXTS AND SCRIPTS

A bibllographic coapllation of noh texte, epanning 400 yeare from B1shō (1504-1520) to Talehö (1912-1926). Contalne entries of 1,500 t1t les conprieing a tocal of 12,000 volumes. Introductory esection explains the meaning, or1ginal composition, chenges, etc. of noh texts. Bibliographic entries of the texts from the Bdo perlod through Malj1 and Talahö eras are further divided by the achoole, Including Kanze, Hoshö, Komparu, Kongo, K1ta, etc.

(Collection of Unpublished Boh Texts)

Ed. by Tanaka Makoto

Tokyo: Roten Bunko

$30 \mathrm{ve}$

A collection, in 30 volumes, of hitherto unpublished noh texts. The texte were reprinted in block characters and simplified by the omission of detalled musical notations and symbols contained in the original manuscript. Texts vere selected from approxinately 29 collections, scattered throughout Japan, Including the Rōyama collection, Kyoto Univeraity Literature Department collection, Tenrl Library, Date Collection of Myagl Prefectural Library, Higuch1 Pamily collection, etc. The introductory section of each volume contains brief bibllographic annotations of the plays. Wost volums contain from 40 to 50 pleys. (Key Points of Solo Chanting Noh Texts) Sakanoto Setchō Tokyo: Nōgaku Shoin 150 p. (Nōgaku zensho, 3 坂

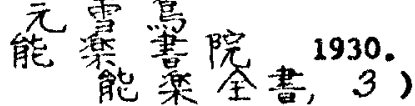

As Le PN2924.5/.N6S35

A manual of helpful hinte and instructions on how to chent noh texts without walcal accompmiment or dancing. Chanting should not be a were recitation of words but should have the proper Intonation, accentuation, timing and rhythmical pattern sulted to the role and scene in the play. Fifteen plays, including harorono (Bobe of an Angle), Koka 11, etc., are taken up and ouggeatlons given oa the key points in chenting the text for each.

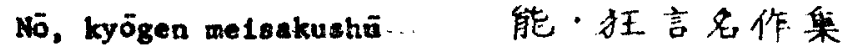

(Collection of Noh and Iyören Materpieces)

Ed. by Yokomichi rio and Furukawa Hisashl 古11! 久 编

Tokyo: Chikume Shobō 筑摩整原 1962.

399 p. 11lus. (Koten Hhon bungake zenshū, 20 古势日本文学 全絜，20) As 1a PL753/.K6/v.20 
NOH TEXTS AND SCRIPTS

A collection of the tage ecripts of 20 noh and 16 kyögen masterpleces. Noh plays include Do1011 (Dojoji Temple). Ataka (Ataka Barrier Cato), etc. which were made into famous kabuki plays. Krogen pleces Include the popular Suehirogarl (An Old Umbrella for - Fan), Böahibar1 (Tled to a Pole), etc. Page are divided Into two horizontal sections of two columns each, with the upper column containg the ecript and the lower column, the explanatione and/or converational version of the text. Appended to a discussion of noh, Ite role as a performing art, descriptiona of texts and ecripte, tages and properties, etc. and synops is of the 20 liated plays. Also attached are five eseays on the historical development of noh, realistic beauty of kyōgen, etc.

An analytical handbook of 240 currently performed plays selected from the varlous noh schools of Kanze, Hosho, Romparu, Kongo, K1ta and Umewaka. Plays are categorized into the five main groups of waki nō mono (god play), shura mono (battle plece), katrura mono (fewate-vig piece), yombanme mono (fourth group plays including genzal mono or present-11fe plece, kyoren mono or lunatic plece, and seven other types), and kiri no mono (concluding plece with supernatural beinge). For each play, briefly noted are charactera, historical perlod and season, place, tructure, theme, noh achool and notations on pecial variatione of the play. Index of playe in Japanese syllabic order is appended. The structural explanation analyzes the lo-he-kyü princlple of the play, describing which act or acts constitute the jo (introduction), ha (development, usually In three stages) and kyiu (climax).

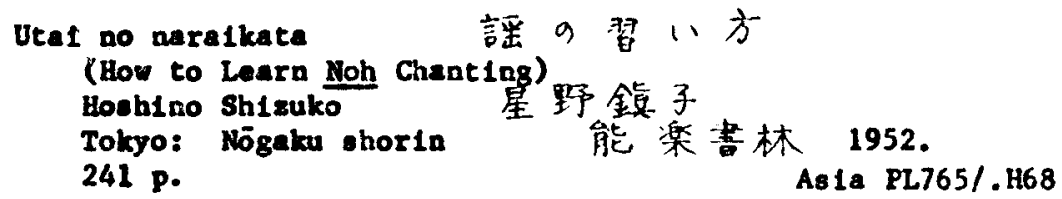

A manal designed to enable readere to understand and to learn to chant noh texts. Divided Into three sections. The introductory section oriente beginners to problems expected at the tart of lessons and the proper ways of enunciating, vocalizing and breathing. The eecond section goes Into the detalls of the actual lessons and diecourses on the accentuation, intonation, rhythm, timing, etc. of chanting. The third section gives polnters on posture, polse, etc. and arrangewent of programe devoted to noh chanta. 
HOH TEXTS AND SCRIPTS

616

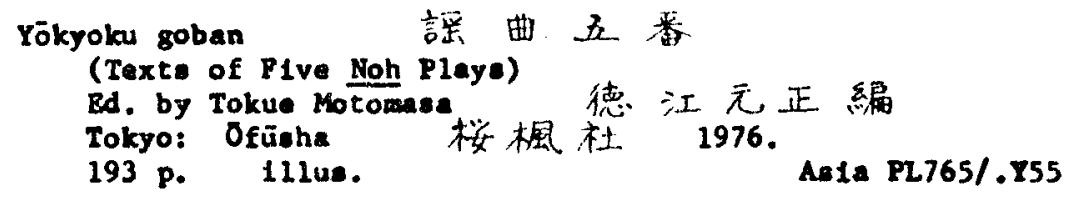

Reprints, In original aize and calligraphy, of five noh texte to be used as instructionel waterials in the study of national language and literature in universities. The five plays are: Zashima, Telka, Sekidera Komach1. Jinenko 11 and puj1to. Synops is and commentaries on the plays are appended. 謡曲評积 (Detalled Comentaries on Foh Texts)

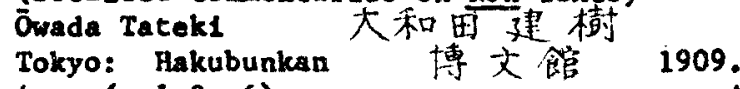
4 v. $(v .1-3,6)$

\author{
As 18 RL $765 / .083$
}

A collection, in 10 volumes, of comentaries on 291 noh texts, mostly of the Ranze school. Bnlarged and revised edition of the Yokyoku tsūkal (Comentarles on Noh Texts) published in 1903. Comentaries are included in the texts as headnotes. Plays aro arranged In Japanese sylleble order. Vol. 1 contalns explanatory articles on the origins of noh, division into varlous noh echools, playwrights, texts, etc. Also included 1s a chare shoulng performancas of different playe by the season of the year. For example, celebratory pleces 11ke Taurukame (Crane and Turtle), Olmateu (Old PIne Trea), etc. are shown In January to get the year off to an ausplclous start.

$$
\text { 显曲・狂容 }
$$

(Noh and kyögen Seripts) Rd. by Koyama Hitroahl and Ritagara Tadahtko 北传忠产 编 Tokyo: Kadokawa Shoten 角 II塞店

$$
\text { 小山弘志。 }
$$

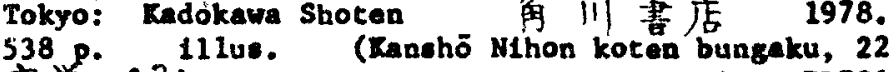
文学, 22) A.1a FL726.1/K33/v.22

A collection of seven noh and seven boogen sage ecripte with detalled explanations to deepen appreclation of the plays as they are parformad on the sage. Hoh playe 1nclude nonomiya, Funa Benkel (Banke1 In the Boat), atc. and työgen playa Includo Sado G1tsune (Sado Fox), Utsubo zaru (The Quiver and the Wonkey), etc. The noh scripte contaln Inetructione and interpretatione which asaiet In staging the plays lacluding footnotes and annotations of the play texte, directione on Instrumentel accompuniment, dance movements and performance of al kyögen (comic interludes in noh plays), etc. 
NOH TEXTS AND SCRXPTS

619

Yökyoku me1saku jüroku-ben shūshaku 謡曲名作十六番軿秋

(Selection 16 Pamous Noh Texta)

Nonomura Ka1zō 野々村诚三

Tokyo: Waseda Dalgaku Shuppambu 早稻田大学出版部 1936.

622 p. Asla PL756/.N655

A selection of the ecripts of 16 representative noh plays, including

Takasago (Takasago Pine Tree), Hagoromo (Robe of an Ange 1) and

Atake (Ataka Barrier Gate). The latter wo were made Into kabukI shosegoto (dance playe) and Ataka is the origin of the popular kabuk1 play, Ranjlnchö (Subcription Llst). For each play, there are brief explanations, Including the syope1s, interpretations of sections of the dialog, descriptions of eignificant places and roles, etc. The introductory ection explaino the historical origins of noh, developwent of noh schools, pecial characteristics of noh. texts, etc.

Yōkyoku monogatar1 謡曲物言

(Noh Textual Narratives)

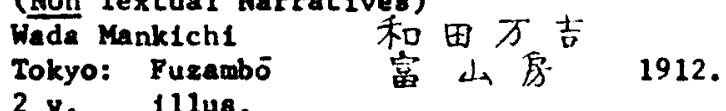

2 v. 111ua. As1a PL735/.W33

A compllation, in two volumes, of 155 noh plays, performed most often presently, by the five maln noh shools. Texts of the most popular school, namely, Kanze, were used, if avallable. The texts are not complete in dialog, stage and musical directions, etc. They are in a nerrative form with oome dialog included. This work 1s Intended as an orientation book for beginners who want to begin the study of authentic noh texts.

Yokyoku n1 erawaretaru bukkgo 謡曲に現中水た名佛教。 (Buddhien in Noh Textg)

Innada Ryoun 花田凌雲

Kyoto: Rokyo Sholn 期教書院 1938 .

411 P. 111ue. As1s PL765/.H35

A collection of 75 noh texts selected for their Buddhistic rolacionships. Plare were categorised by the varlous sects. To clte examples, the play Sumideseme (Suntda River) for 1ts association with Jodo sect, Atele (Atake Bartier Gate) for Shingon sect, Tamura for Kannon devotees and Opeeute (Abandoning Old Women) for general Buddhistic relations. Preceding each category is a diecuselon of the influences of the particulax sect soen in the eelected plays and for each play, the Buddhiet significance is pointed out. A gloesary of Buddhist terms used in the taxts is appended. 
IOR TEXTS AND SCRIPTS

(Noh Text Salections)

Ed. by Takano Tatauyuk

Tokyo: Kōfükan 光風館 1926 .

238 p. 111us. As1a PL735/.T34

Noh and kyōgen texts selected as language Instructional materialo by the Tokyo Hulic School. Trenty noh playe, Including the popular Takasego (Takasago PIne Tree), Yashlma, Funs Benkel (Bonke1 in the Boat), etc. and five kjōgen playe, including Suehlrogert (An old Umbrella for Pan), Kōyakuneri (Salve Vendor), etc. are Included. The introductory section presents concise explanation of noh and kyögen origins and performances.

(Selections of Noh Texts)

Sanarl Kentarō 传 成 涤太郎

Tokyo: Melj1 Sholn 明治表院 1933.

502 p. Illus.

As 1a PL765/.\$35

A compilation of 30 noh texts selected from the author's work, Yökyoku taikan (Comprehensive Collection of Noh Texts), wh1ch presents 236 texts in seven volumes. From the standpoint of play composition, plots, etc., the 30 texts were selected as best representing each of the five main noh groups. Each text is an exact replica of that in the comprehensive work and contains detalled interpretative headnotes and footnotes. Examples are Takasago (Takasago Pine Tree) for the wakt nō (godi play), Tamura (second group), hagoromo (Robe of an Angel, third group), Ataka (Ataka Barrlex Gate, fourth group) and Funa Benke (Benkei in the Boat, fifth group). The preface notes distinguishing noh features as follows: that it has phantasmic qualities and performers are intermediaries who bring back historical characters from the past to present: that it has contributed to raising national morals by emphasizing spirttual values such as loyalty, duty, obligation, etc.; and that it is the nucleus of Japanese 11terary arts, because noh texts draw heavily from the ancient classics. The introductory section also contains discussions on structure, costumes, music and dance patterns, etc. which are helpful in staging noh performances. (Selection of Noh Texts)

Wada Mankichi

Tokyo: Sankaidō

449 p. 111us.

As 1a PL765/. W33

A compllation of 36 representative noh texts, each preceded by a synopsis. Definitions of terms are interspersed in the texta. The plays were classifled Into the five traditional groups. 
NOH TEXTS AND SCRIPTS

Following are the groups, number of plays and a representative play: Firet group, wak1 nō (god play), three plays, Takasago (Takasago Plwe Tree); second group, ehure mono (battle ploce), olght plays, Samenor 1; third group, katgura mono (female-wig plece), nine plays, Izuteu; fourth group, 11 playa, Sumldagawa (Sumida River); and fifth group, five plays, Puna Benkel (Benkei in the Boat). (Note: The five representative plays cited above have been translated in the Japanese Noh Drama, UNESCO Collection of Representat Ive Horks: Japanese Series, Tuttle, Tokyo, 1955.)

Yōkyokushū 謡曲集

(Collection of noh Texts)

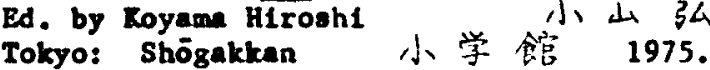

516 p. 11lus. (Nihon koten bungaku zenshu, 33-34 日本古典 文学全集, $33-34$ ) As 12 PL753/.N57/v.33-34

A collection, in two volumes, of 77 noh texts, arranged by the five main types of noh plays: wakl no (god play), shura mono (battle plece), katsura mono (female-wig plece), yombanme mono (fourth group) and kiro nō (final plece). Yombame nono includes miscellaneous plays such as lunatic plece, obsession pleces, present-life pleces, as contrasted with the phantasmal pieces, etc. Constitutes Vols. 33 and 34 of Nhon koten bungaku zenshü (Collection of Japanese Cleselc Literature). The Introductory section of Vol. 33 contains a detalled explanation of noh as a performing art and the concluding section of Vol. 34 containe a glosesry. Headnotes describe words and phrases used while the footnotes give a conversational version of the text. With atage directions and photo lllustrations, this works serves a a reference in taging noh performunces.

(Collection of Loh Texte)

Ed. by Yokontchi Mario and Owote Akira 表童 編

Tokyo: Imanand Shoten 岩波書佔

2 v. 111us.

文学大系, 40-41)

\section{横道万里雄。}

1960-1963. ta1ke1，40-41 日本古典 As 1a PL753/.N55/v.40-41

A collection, In two volumes, of 103 noh texts arranged chronologlcally by pleywrighte to reflect historical changes in noh drama. Constitutes Vols. 40 and 41 of Mhon koten bungaku talkel (Japanese Clesele L1terature sories). Vol. 40 conteins 45 pleys, beginning with aight by Rannani (1332-1386), 21 by zeand (1363-1443), four by Ranze Motomase (ca. 1394-1432) and 12, miscellaneous. Arong the miecelleneous 1s Aol-no-ue (Lady Aol Possessed) which zeand is balleved to have achored or revised. Vol. 41 contains 58 plays by writers includiag Kouparu zench1ku (1405-1470?), Myamasu (f1. 15th century), Ranzo Nobual teu (1435-1516), Kanee Nagatosht (1488-1541), Komparu Zompo (1454-15207), at al. Nobuat teu's playe Include Moal11gert (Maple- 
NOH TEXTS AND SCRIPTS

Iewing), Atake (Ataka Barrier Gate), Fune Benkel (Benkel in the Boat), etc. which were made into kabuki playe referred to as meteubam mono (pine and boexd plays), and showed their noh origine by the back wall stage satting of a peinted pine trea.

Yōkyoku talkan 言击曲大，错

(Comprehansive Collection of Woh Texte)

Rd. by Sanar 1 Kentarō

Tokyo: Mifll Sholn

$$
\begin{gathered}
\text { 传成誈太郎编 } \\
\text { 1930-1931. } \\
\text { As1a PL765/.s2 }
\end{gathered}
$$

A comprehensiva collection, In seven volumes, of 235 noh texts, arranged in ayllabic order, plus the celebrated piece, Okina (01d Men), treated spectally at the vory beginning. The Introductory volume (unnumbered) describes noh perforences, origin and developaents, uignificance, etc. Vola. 1 through 5 contain the texts, with haadnotes explaining the text and footnotes presenting the conversational version. The supplemental volume (unnumbered) contains the texts of 46 lusemal (maln dance section) of noh playe and an Index of well-known words and phrases which appear in the texts. Th1s work is considered Indispensable for the study of noh texts.

(Comentarles on Noh Texts) Ed. by Öwada Tacek1 Tokyo: Hakubunkan $1 \mathrm{v}$.

$$
\begin{aligned}
& \text { 大和由侓一樹編 } \\
& \text { 博文领 } 1903
\end{aligned}
$$

A compilation of. over 200 noh texts, taken minly from the Kanze school, with comments and explanations in the headnotes. This is an enlarged edition of the ortginal work which was published in 1892. To facilttate reading, the texts are publiehed in large block characters with hiregena reedings. Vol. 1, containe eseaye on the origins of noh and tts predecessor, sarugaku, playrights and actors ete.

婹 曲全霖 (Complete Woxks on Whh Texts)

Ed. by Rakauch $\mathrm{Chö} \overline{\mathrm{j}}$ and Tamura Mishlo Tokyo: Nihon Onkyoku Zenshü Kankōkat 497 p. (NIhon onkyoku zenshū, 12
中内蝶二:田村西男編

日本害曲全集刊行会1927。 日本部曲全箱， (2) As 1. Mil. $340 \%$. $855 / \mathrm{v} .12$

A compllation of 66 popular noh text from the five echool of tanze, Hōshō, Komparu, Kongō and Kita. Plays are arranged In Japanese allabic order. Hadnotes Identify tha roles of hite (main actor), yakt (eupporting actor), toure (attendante), otc. and axplain terws in the text. A brief interpretative analysio of the play is given at the end of each text. Musical syobola are included to enablo use of the work in practlcing noh chants of fawous plays. 


\section{Miyao Shigeo} Tokyo: Hinok1 Shoten 385 p.

111us.

है

1977. As 1a PL766/.MS

A study of kyōgen (classical comedy) plays of varlous prefectures, Including Kyoto and Nara, and Saga in the south to Iwate in the north. The author has selected plays which are on the verge of extinction and complled the plays for posterity into this one volume.

Ilzawa Tadasu kyōgenshü (Kyögen Collection Iizawa Tadasu Tokyo: Miralsha 114 p. 111 us.

$$
\begin{aligned}
& \text { 既沃匡抂言集 } \\
& \text { of Ilzawa Tadasu) } \\
& \text { 湌沢 E } \\
& \text { 未来社 }
\end{aligned}
$$

Five new kyogen (classical comedy) plays written by Ilzawa Tadasu (1909- ), a playwright and drama critic. As the author himself claims, he is probably a "record holder" In writing new kyogen plays and in so dolng, has tried to malntain the 700-year old tradition of kyogen art.

(Selection of Kyōgen Plays with Explanations)

Ed. by Wada Mankich1 和田 万吉縟

Tokyo: Melji Shoin 明治声院 1930.

312 p. 111us.

As 1a PL766/.1H33

A selection of 26 kyōgen (classical comedy) plays from the Okura school, which is considered to have the oldest tradition in this performing art. The 26 plays were chosen from among 122 scripts, belleved to have been recorded 150 to 160 years ago, and preserved by the Ojkura school. Plays in th1s work 1nclude Ramabara (The Sickle and Injured Pride), Kaminarl (Thunder God), etc. Explanatory headnotes help clarify vague or difficult terms and phrases.

Kokyōgen da1hon no hattatau ni kanghite no ghoshigakutek1 kenkyī

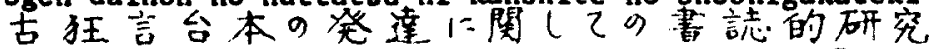
(BIbllographic Research on Development of Old Xrösen Scripts) Ikeda Hirosh1 Tokyo: Razama Shobö 873 p. 池田 店方 虽間黑房 1967. 
KYŌGEN

Through systematic studien of old kyōgen (classical comedy) scripts, Including the Tenghö kyögembon (Tensho Script Book), claimed to be the oldest record of kyōgen plays whlch was published in the Tensho (1573-1591) perlod, various ancient script books st111 extant, cepresentative acripts of the various ages of Edo period, etc., the author examines and denotes concretely the aspects of kyōgen which changed or which became atabilized in time and tried to determine the historical factors which influenced the development.

634

635
Kyögen hyakuban 狂言 百 番

(Kyögen One Hundred Plays)

Kitagawa Tadahiko

Kyoto: Tankö Shinsha

212 p. 111us.
北济交新社浐1964.

A guldebook to kyōgen (classical comedy) with/brlef synopses and photo lllustrations of 87 representative plays. Included are plays such as Higeyagura (Fortifled Beard), Futarl dalmyo (The Two Peudal Lord8), etc. Appended is a brief article on the "Changes and Present Status of Kyögen," In which the play, Busuzatō (Polsoned Sugar) is discussed as an example.

Kyōgen j1ten 狂. 言 辞 典

(kyögen Dictionary)

Furukawa Hisashi

Tokyo: Tokyodō

2 v.

東古浐、堂 $1963-1976$.

As 1a Ref. PN2924.5/.K9F8

Published in two volumes. Vol. 1 emphasizes vocabulary and defines words and phrases to help understand kyögen (classical comedy) texts. Indcxes of plays, names, quotations, etc. are appended. Vol. 2 contains words and phrases which will assist in the study and appreciation of kydgen plays. Multiple indexes of terms, plays, personal names, performing groups, dialog, pal (dance), etc. are also appended.

Kyōgen kenkyū: kōsatsu to kanshō

狂言研究一，考察と轱監賞— (Xyogen Research: thoughte and eppreclation) Sugimor1 Miyoko 杉森美化子 Tokyo: Ōfüsha 栟相杜 1969 。 261 p. 111us. As1a PN2924.5/.X9S83

Comprised of two sections. 1. Thoughts and comments on the kyōgen (classical comedy) text by Okura Toraakira. 2. Explanations and interpretations to help apprectate representative kyōgen plays. Plays are classifled generally into the following typeg of kyōgen: wak1 (supporting actor), dalmyó (feudal lord), Tarō kala (clown), muko (brldegroom), onna (woman), onl (ogre), yamabush1 (1t Inerant monk)., shukke (prlest), zatō (bIInd man) and atbume (miscellaneous). 
KYŌGEN

637

$$
\begin{aligned}
& \text { Kyögenk1 狂 言 記 } \\
& \text { (Record of Kyōgen) } \quad \text { 三浦 理 㬎 } \\
& \text { Tokyo: Yưöó Shoten 有朋堂書店 } 1914 \text { 。 } \\
& 2 \text { v. 11lus. As1a PL753/.Y88 }
\end{aligned}
$$

A collection, in two volumes, of 200 kyōgen (classical comedy) plays of Izumi school. The original version was titled Elri kybgenkt (Illustrated Record of Kyogen) and was published during the Cenroku (1688-1703) period. These two volumes were edited in the form of stage scripts. Brlef explanatory headnotes are included. The first volume contains plays such as Kakiuri (The Persimmon Seller), Rokuninsō (The Six Priests), etc. and the second, Böshibari (Tied to a Pole), Utsubozaru (The Quiver and the Monkay), etc.

(Kyögen Masks)

Nomura Manzö

Tokyo: Wan'ya Shoten

150 p. illus.
野村 万葴 わ人や喜店 1956 .

As 1a NB1310/.N65

With ample use of 1llustrations, explains kyogen (classical comedy) masks from various viewpoints, such as their beauty, genuineness, usage, art of making and preservation. There are numerous varleties, including masks of defties, humans (showing anger, humor, agedness, youth, etc.), animals, etc. Also, describes 31 types of kyögen costumes and $118 \mathrm{~s}$ various kinds of hand props.

Kyögen no kenkyū

(Research on Kyōgen)

Furukawa Hisaght

Tokyo: Fukumura Shoten

$361 \mathrm{p}$.

$$
\begin{aligned}
& \text { 狂 言 } 9 \text { 研究 } \\
& \text { 古师村䈏店 } 1967 \text {. } \\
& \text { As 1a PN2924.5/.K9F8 }
\end{aligned}
$$

Examines and Interprets the various facets of kyogen (classical comedy) plays, Including Zeaml's view of kydgen, the roles of koado (supporting actors), as contrasted with shlte (maln actors), masks and costumes, etc. Contains a glossary of kyozgen terms, many of which are difficult words derived from medieval colloquial language.
Kyōgen no seka1

(World of Kyōgen)

Furukawe HisashI

Tokyo: Shakal Shiso Kenkyuika1

150 P. 111us.

$$
\begin{aligned}
& \text { 狂言 } 9 \text { 世界 } \\
& \text { 古川 久 }
\end{aligned}
$$

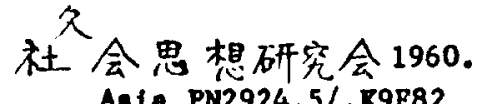


KYōGEN

A convenient handbook to grasp the highlights of kyögen (class1cel comedy) including its historical background, present status, synopses of 100 famous plays, iiterature associated with the art, etc. Photos of masks, costumes and stage ( $\mathrm{ama}$ as noh) are Included. The appendix contains an article, "Overseas kjögen," noting that kyögen was fiost performed abroad In France in 1957 and plays have been translated Into French, German, Russian and English, the latcer Including translations by Basil Hall Chamberlaln and Arthur Lindsay Sadler.

Kyōgen: "okashi" no kelfu 狂㝘—走かし」g系譜 (Kyōgen: Genealogy of Comedy) Ed. by Geinōshi Kenkyüka! 芝能史研究会編 Tokyo: Heibonsha 平杜 1970 . 265 p. illus. (Nikon no koten geinö, 4

Analytical study of kyōgen (classical comedy). Considers kyōgen from three main viewpolnts: history and appreclation, play elements and distinguishing features, and guide to research. Discusses the development of kyógen as a comical entertalnment for the common people, its relations with the more serlous and sophlsticated art of noh.

Kyögen o tanoshimu (Enjoyment of Kyōgen) Kobayash1 Isao Tokyo: He Lbonsha 152 p. 11lus.

$$
\begin{aligned}
& \text { 狂言をたのしを } \\
& \text { 小林责 } \\
& \text { 平凡社 } 1976 .
\end{aligned}
$$

As 1 a PN2924.5/.K9K6

A compact handbook, with numerous color photos, to introduce kyōgen (classical comedy) from a personal vieupolnt. The author expresses his own interpretations of the comlcal aspects of kyōgen and the enjoyment he derives from them. Included are his historical account of the development of kyōgen, particularly its differences from noh. Presents an Interesting personel insight into various aspects of kyogen.

Kyögen: rakuheku shlta kam1gami no hembō

王

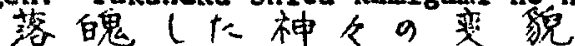
(Kyōgen: Transformation of Fallen Gods) Toida Mlchizo Tokyo: Heibonsha 277 P.

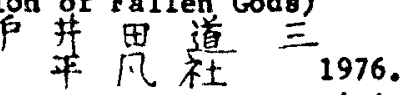
As 1a PN2924.5/.K9T6

A compilation of the author's articles published sporadically between 1966 and 1969 in the magazine, Higekl kigekl (Tragedy and Comedy). Organtzed into two parts: Part 1, titled, "The Group Comprising the Kyögen World," discusses typlcal kyogrn (classical 
KYōGEN

comedy) characters, such as Tarōkaja (clown), yamabusht (1tinerant monk), shukke (priest), etc. and animals including monkeys, foxes, etc. Part 2, titled, "Characteristics of Ryögen," compares kyōgen with noh and points out the simllarities and differences, particularly the secondary role of kyögen.

644

Kyōgen rikug1 狂言六等

(Kyögen R1kug1 Text)

Tenri: Tenr1 Daigaku Shuppambu 天理大学出版部 1975-1976. 3 v. As 1 a PL766/.K86

The oldest kyögen (classical comedy) texts called Rikugl, in three volumes, of the Izumi school. Vols. 1 and 2 contain a total of 222 kyōgen play scripts whlle Vol. 3 includes miscellaneous collection of songs, stories, poems, etc. The Rikugl 18 belleved to have been complled in the mid-17th century by either Yamawak1 Izumi Motoyoshi (? - 1659), 7th master of Lzuml school, or his adopted son, Yamawak1 Gorozaemon Motonaga (? - 1645).

Kyōgen ronkō: setsuwa kara no keise1 to sono tenka1 論考—説話心的9形成と展開 (Study of Kyögen: Development from Story-telling and Its Evolution) Taguch1 Kazuo Tokyo: Mitsuya Shoten 时口和夫 347 p.

王 三弥萋店 1977 . As1a PN2924.5/.K6T28

A historical survey of the development of kyogen (classical comedy). Describes kyögen as it existed durlng the middle ages, primarily the Ramakura (1192-1333) and Mromach1 (1390-1570) periods. Discusses the changes in characters and performances over the years. Pays particular attention to the Sagi school of kyzgen as th existed in the Tokugawa period (early 17 th century). Notes the role of kyögen as a performing art during different historical perlods.

Kyōgen sambyakuban shü 狂言三百番策 (Collection of Three Hundred Kyōgen Plays) Ed. by Nonomura Kaizō and Andō Trunejirō 安藤常次郎校注

Tokyo: Puzambō 1938-1942。

2 v.

A. La PL766/.K96

A collection, in two volumes, of 316 kyōgen (clasatcal comedy) plays. For each play, costumes for each role are noted at the beginning. Glossaries and play indexes are appended. The flrst volume contains a rather detalled historical and descriptive narration of kyōgen. Plays from Okura, Izuml and Sagi (now défunct) schoola are covered. 
KYōGEN

Kyōgeneh1 kenkyū 狂 言史研究

(Study of Ryogen HIstory) 小林 责

Tokyo: Wan'ya Shoren t人凊店 1974.

294 p.

As 1a PN2924.5/.K9R62

Traces the orlglns and developments of the three main schools of kyögen (clasalcal comedy), namely, Ōkura, Izumi and Sag1. Ōkura and Sagl schools were affiliated with yoza sarugaku (four main sarugaku schools) and recefved the support of the Tokugawa Shogunate while Izumt began as a more localized school backed by the Tokugawa clan of Owarl province (Aichi prefecture) and the Kaga clan (Lohłkawa prefecture). Sagi was a comparatively new school and its demise In the Melji perlod is attributed partly to its association with kabuk1.

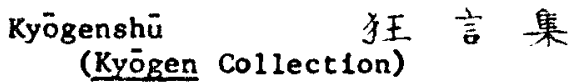

Ed. by Furukawa Hisashi

Tokyo: Asahl Shimbunsha

3 v. (Nihon koten zensho

古11久校注

俱日新開社 1953-1956。

日本古典全畫)

A collection, in three volumes, of 100 kyōgen (claselcal comedy) plays of the Sagi school (now defunct) of Kyoto. Plays were reprinted, In block characters, from the coples scripts preserved in the Itakura famlly. Detalled headnotes accompany each play. Vol. 1 contalns an essay by Nonomura Kaizō discussing word eeanings, historlcal background, play structure, stage, blbllography, etc. Nonomura polnts out that kyögen fully developed into a performing art around the Nambokucho $(1336-1392)$. Vol. 2 consists of plays and vol. 3 containa an index of plays.

Ryōgenshü collection) 言 集

Ed. by K1tagawa Tadahtko and Yasuda Akira 北㸪忠彦 安田章校注 Tokyo: Shogakkan 小学舘 1972 . $593 \mathrm{p}$.111us. (N1hon koten bungaku zenshū, 35 日本古典 文紫全慗，35) As la PL753/. N57/v.35

A collection of 40 kyogen (classical comedy) plays of the Okura school. Each play has illustrations and explanatory headnotes. The introduction section explains the history, types, acting patterns, characteristics, dialogs, etc. of kyogen. Written simply and serves as an orientation guldebook. Begins with the famous kyogen piece, Suehirogar1 (An Old Umbrella for a Fan), and appended is "Annotated Famous Kyōgen," a list of representative plays, with synopses, not included in the text. 
KYōGEN

Kyōgenshü 狂 言重

(Kyögen collection)

Ed. by Koyama Hirosht

Tokyo: Iwanami Shoten (N1hon koten bungaku talke1, 42-43

古典丈学大系, 42-43)

A collection of 110 kyōgen (classical comedy) plays complied in two volumes. Detalled headnotes and stage directions in the book enable readers to visualize the actors' performances. Intended for reading entertainment. Points out the three elements of katari or serlfu (dialog), kouta (song) and komal (dance) which make up a kyōgen play. The serifu usually predominates in kyōgen.

Kyơgenshū: Izumiryū (Kyögen Collection: Tokyo: Koten Bunko $20 \mathrm{v}$.

$$
\begin{aligned}
& \text { 狂言集一和泉流 } \\
& \text { 吉典文事 }
\end{aligned}
$$

A collection, in 20 volumes, of kyōgen (classical comedy) plays of the Izumi school. Plays are reprints, In calligraphy, of the Izumi school text called, "Kyōgen Rikug1". The collection contains 200 plays, Including Sannimpu (Three Peasants). Sannin chōjo (Three Mililonalres), etc.

Kyōgen shūse1 狂言集成

(Collection of Kyögen Scripts)

Ed. by Nonomura Kaizō and Andö Tsunej1rō 野々村成三，安藤常次郎編 Tokyo: Nōgaku Shorin 能策寒林 840 p. 1974. As 1a PL766/.N63

A collection of stage scripts, reprinted in block characters, of about 740 kyōgen (classical comedy) plays. Most of the plays belong to the Iruml school and were edited for this source book according to the Rlkugl (text) of the Myake branch of Ixuml school. Several plays of the Okura and Sagi schools are also included. Plays are generally divided Into hon kyōgen (kyögen proper) and ai kyoggen (noh comic interludes). Four plays of the third kyōgen type, Sambasol furyd (auspiclous/elegant) plays are presented. The first play l1sted is the popular, congratulatory play, Sambaso (Three Peasants).

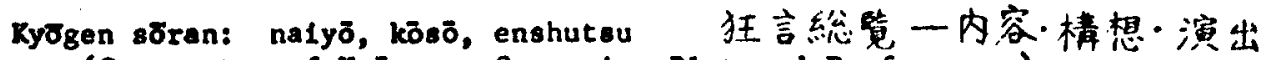
(Conapectus of Kyögen: Synopsis, Plot and Performance) Andö Taunejlrō, et al. Tokyo: Nögaku Shorin 470 p. 111us. 䒵藤常次郎等。 能架素林 1973. As 1a PL736/.K9 
A comprehensive guldebook to kyogen (classical comedy). Introductory section outlines its orlgin and development, classification and 8 chools of kyōgen plays, acting techniques, and physical properçes including stage, masles, costumes, props, etc. The main section discusses 10 types of claselfication, Including vakl (supporting actor) kyögen, dalmyō (feudal lord) kyögen, Tarōkaja (clown) kyōgen, etc. Within each class, Individual plays are taken up and the synopsis, plot and acting technique for each are given. Appendices Include a glosary, bibllography and chart of famous plays, performing school, number of actors, etc.

(Complete Works of Kyögen)

Ed. by Kokumın Bunko Kankōka1

Tokyo: 1910.

804 p.

\author{
金 \\ 国民文庫刊行会 \\ Asia PL753/.K65/v. 14
}

A comprehensive compllation of 200 kyōgen (classical comedy) plays, reportedly of the Isumi school. Plays were taken from the following works, each of which contained 50 plays: Kyögenki (Record of Kyogen), published 1n 1699, Zoku kyögenk1 (Cont1nued Record of Xyogen), 1700, Kyögenk1 shüt (Gleanings from the Record of Kyogen), 1730, and Kyögenkf gathen (Supplemental Record of Kyogen), 1700. In addition, 20 plays of the Sag1 school are appended.

Men to kyögen

(Masks and Kyỏgen)

Takano Tatsuyuk1

Tokyo: Tokyodó

219 p. 111us.

$$
\begin{aligned}
& \text { 面と狂 言 } \\
& \text { 高野 辰之 } \\
& \text { 束京堂 1942. } \\
& \text { As1a GT1747/.T35 }
\end{aligned}
$$

Consist of three sections. The firat section, "Classic Masks," takes up and explains glgaku, gyōdō and bugaku masks. The second section, "Kyōgen Pepertolres," discusses various types of kyögen (classlcal comedy) plays as clessified by the Dkura school. The third section depicts the "History of Performing Arts and Mulc In Nara."

Mibu kyōgen

(Mibu Kyögen)

Aral Yasuo

Tokyo: Tairyūsha

204 p. 1llus.

$$
\begin{gathered}
\text { 生狂言 } \\
\text { 抹保男 } \\
\text { 䏾流杜 }
\end{gathered}
$$

1976.

As 1a PN2924.5/K9A67

A photo album of kyögen (classlcal comedy) plays speclfically performed at Mibu Temple in Kyoto. Photos, in both color and backand-white, are arranged as follows: kyögen beauty, masks, faclal expresstons, movements and acting patterns. Synopses of $30 \mathrm{MIbu}$ plays are given at the end, including those derived from noh, such as Funabenke1 (Benke1 in the Boat), Dojoit (Dojojl Temple), Isuchlgumo (The Monstrous Spider), etc. 
KYס̋GEN

Nihon shomin bunka shiryō shüse1, da1-4-kan, kyögen $\quad$ 日 本 庶民文化史料集成，第的卷：狂言 (Ryogen) Ed. by Gelnōsh1 Kenkyūka1 Tokyo: San' Ich1 Shobō 764 p. $\quad 111 u s$.

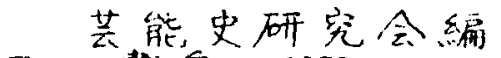

$$
\begin{aligned}
& \text { 三 - 昚象 } 1975 \text {. } \\
& \text { As 1a PN2920/.N5/v.4 }
\end{aligned}
$$

Volume 4 of the 15-volume Nihon shomin bunka shiryō shūsel (Collection of Materials on Japanese Popular Culture) ls devoted to kyōgen (classical comedy). Provides a comprehensive coverage and serves as source materfal for the study of kyögen. Divided into three maln sections: 1. Four schools of kyogen, discussing the Izumi school text called R1kug1, and Ōkura school text called Densho. 2. Sagl school kyogen which still exist in the outlying districts such as N11gata and Yamaguchl c1ties. 3. Kyögen as folk entertainment performed in such areas as Gifu, Shizuoka, Nara, etc.

Noroma coroma kyōgen shüsẹ 1: dōke n1ngyō to sono ke1fü, 093

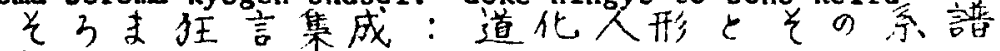
(Collection of Noroma Soroma Kyögen: Clownlsh Puppets and Genealogy) Sh1noda Jun'1chi and Saltō Seljirō 信多純一，素萑清二郎 Kyoto: Dalgakudō Shoten 大学堂暂店 1974. 642 p. 111us. As 1a PL766/.N66

A collection of scripts of early perlod noroma kyögen (classical comedy), soroma kyögen plays, etc. which used clownish puppets in the acts. Scripts were reprinted in block characters. These acts were performed during the interludes in plays of noh, kabuk1 dances, puppet shows, etc. Soroma kyögen first appeared In Kandgata (KyotoOsaka areas) around 1677 and noroma kyogen in Edo around 1679. Th1s work contains photos of the clownish puppets, that still remaln, and stage scenes. Also, delineates the genealogy of the puppets.

Ōkura Toraak1ra-bon kyōgenshū no kenkyū 大藏虎明本狂言果の研究 (Ōkura Toraak1ra's Text: Study of Kyögen Collection) Ikeda Hirosh1 and Kitahace Yasug 池田広司, 北原保雄 Tokyo: Hyōgensha 2 v. (v. 1 and $v, 2$ )

Reprint, in two volumes, of Ōkura Toraakira's text of kyogen (classical comedy) plays. Serves as valuable source materlal for the study of kyögen art from Muromach1 perlod (1390-1570) to early Edo period (early 17th century). Okura Toraakira (1597-1662) was one of the foremost kyögen performers and writers. (Tôkurö's New Kyōgen Collection) Myake Tokurō N Tokyo: Nögaku Shor in 能集書林 1975. 349 p. 111us. As 1a PL833/. I876A19 
KYŌGEN

A compllation of 25 new kyōgen (classlcal comedy) plays, 16 komaluta (short dance and song) and two noh-al (noh comic interludes) by Míyake Tōkurō, a kyōgen playwright, actor and choreographer.

661

Warambegusa (kyōgen mukashlgatarl shö) kenkyü

わ 5 んへ 草

(狂言黄語抄) 研究

(Study of Warambegusa, Excerpts of 01d Kyögen Storles)

Yonekura Toshiaki

来合利昭

Tokyo: Kazama Shobó

786 p.

風間書房 1968 。

Asta PL795/. $84 \mathrm{~W} 338$

A thorough study of the only authoritative, theoretical book on kyögen (classical comedy) called Warambegusa, written by Ōkura Toraakira (1597-1662), the 13th master of the Okura school. Warambegusa consists of flve volumes and took ten years (1651-1660) in writing. The study is composed of two parts: Part 1 analyzes the historical development of kyōgen, thoughts of ökura Toraakira and theories about kyögen prior to Warambegusa. Part 2 is the actual study and consists of five chapters, describing its origin, influences on the author, organization, framework of the theorles and relations to noh, and the evaluation of Warambegusa. 
Arranged in two eections. In the flrat ection, the fundamental characteristice of dancing are searched by examining its hietorical developmonts, special qualitles of beauty. arrangement and composition of dance expressions and their effects. In the second section, emphas is is placed on determining way in which dancing contributes to the bullding of humen character.

Buyō ge1wa 舞 踊 蓄 話

(Professional Dance Talke of Mitsugorō Bandō VII)

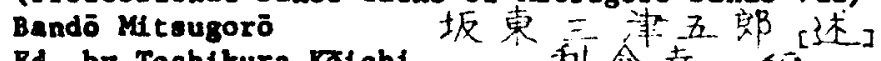

Bd. by Toshikura Kolchi

Tokyo: Engek1 Shuppanehe

利舍辛一編

190 p. 111ue.

潧虔出版社 1977 .

A collection of comments on his professlonal dancing career by Bandó MAtsugoró VII (1882-1961), who was head of the Bandō School of dancing. Appended is a genealogical survey of the Bandö Mitsugorö family.

Buyō Rach1wag1 ryĩ shl 锖踊木流史 (Bletory of Resh1wagt School of Danc1ng) Mateumoto ramemateu 松本危，松 Tokyo: Buyō Rashiwaglryūahl Ranköka1 1965.

449 p. 111us.

As 1a G1695/.MO

Recorda the h1story of the Rashiwagi School of Japanese dancing. The book consiets of four parts: 1) hiotortcel developants, 2) hietortcal analyses, 3) blographical series, and 4) fantly recorde.

Buyō: Klnsel no uta to odorl (Burō: Nodere Songe and Dancee) Ed. by Celnōsht Kenkyüical Tokyo: Halbonsha 346 p. 11140. 平风社

缶踊一近世の歌と踊少

芸能史研究会編 1970. (Rihon no kotan gelnō, 6

Ala P12921/.0153V6 
JAPANBSB DANCR

Describes the role of dances in the performing arte hiatory of Jepan and analyzes the efgnificance of dances in the dally lives of Japanese people. This work conetitutes Vo1. 6 of Mihog no koten reinö (Classic Perforalng Arts of Japan).

(Costumas for Japaneae Stage Dences)

Rd. by Rubota Kincen

Tokyo: Buyō no Zosoo1 Kanköka1

久保田金遷編

I v. illus.

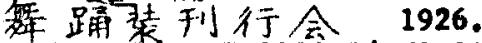
As Ia FO X PL2924.5/.20388

Selects and explaina famous Japanese stage dances and provides detalled descriptions of costumes needed for each. Explains in minute detall each plece of epparel that should be worn, fron head to toe, and the propar manner of dressing. Includes color photos of dancers and sketches of etages and hand propa. A valuable reference for btaglng Japanese dances.

Buyō oyobi kageki talkan

舞踊及歌劇大観 (General Survey of Danclng and Musical Dreme) Teubouchl Sh1kö t平肉士行 Tokyo: Tokyodo 367 p: 111ne. 東行案 1925.

A beginner's guide, which alms to widely convey to laymen readers, general concepto as well as epectfic information on Japenese and Weatern dancing and muslcal drama.

Bdo kineel buyōah1 江卢近世虂史

(Recent History of Dances in Edo) Rokonod Sakon Tokjo: Banrikaku Shobō 580 p. 九重左 近

Ut1lizing the kabukt nendatk1 (Kabuk1 Chronology) and jörurt (narrative storyteliling) texts as source naterials, the author 11sts and cleselfies kabuki dances and gives detalied descriptione of their igniflcance, changes ince thair origin, types and Interpretations of dances, record of etage performances, etc.

Bdo no wal to odor 1 no füzokusht (Hietorical lotes on Bdo Perlod Dances) Ono Takeo 小, 里予 武雄 Tokyo: Tembōeha 展望社 416 p. L11us. 江户g繁と踊の風俗誌

Describes the origin and features of Japanese dances which were popular during the Edo perlod. Ukiroe prints are noed as illuetrations to capture the mood of the period. 
JAPANESE DANCB

670

Hōgaku buyō j1ten

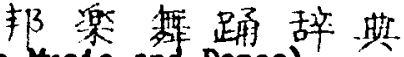

(D1ct1onary of Japanese Music and Dance)

Ataund Seltarō

Tokyo: Tuzambō

459 p.

溹美山清太蚛

1956.

Aste Bef. ML108/. A89

Th1e dictionary covere mulc, dance and theater of the last four centurles. Bntries are written in Romanized format and arranged alphabetical1y. There to an Iodex arranged by Japanese eyllabary. Includes titles, types and contents of songs, 1yriclets and conposers, first performers, dates of firat performance, etc.

671 Högaku höbve 邦集邦舞

(Japanese Malc and Japanese Dance)

Bd. by Tobe Ginsaku F部金艮作 编

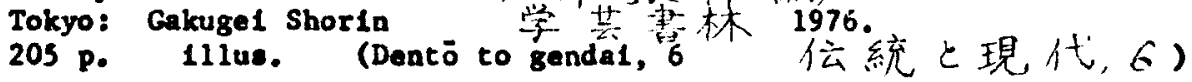

A compllation of essays by experts on the past, present and future of Japanese dances and Jepanese music (speciflcally geza, or off-stage walc to eccomany dancing). Introduces concretely, with the ald of 1llustrations, various techniques eaployed in the art of Japanese dancing.

丰栥と舞踊

(Japanese Kuselc and Dance)

Bd. by Myrual Yoohto

Tokyo: Bögaku to Buyösha

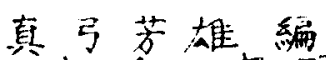

邦梁と舞踊杜 1962-

Al1e GV1695/. 1664

A wonthly, pictortal periodical devoted to Japanese muelc and dance. Contains fonture articles, serials, curront news, etc. on activities and personalities in the fields of music and dancins.

Hyō Jun Rhon buyōfu

標潗日本舞踊言普

(Standard Jepanese Dance Score)

Tokyo Tokne itsu Bunkeze1 Tenkyū jo

Tokyo: Sögetsha

制望 杜

束京国立文化期研究所

209. 147 P. 11lus.

Provides detalled descriptions of Japanese dances with the use of choreographic notations. Ate to standerdize the notations and their usage. Gives exemples of the tandardized score for varlous echools of Japenese dencing. 


$$
\begin{aligned}
& \text { Inoue Yechlyo gelwa 牛上八千代芸話 } \\
& \text { (Inoue Yach1yo Inike of Hor Forforaing Art) } \\
& \text { Ratayam Kolj1rö 片 山度治郎 } \\
& \text { Kyoto: Kawera Shoten 河湶曺店 } 1967 . \\
& 301 \text { p. 111us. Aala G1785/.I57A3 }
\end{aligned}
$$

Inoue Yachlyo IV, current heed of the Inoue School of dancing, talke about her life and expertences as professlonal dencer for 50 yeara. Story wa compllad by her eon. Bandō Minosuke and Tosh1kura Kölcht 利會幸 -

Tokyo: Rensetausha 津設杜 1937 . 313 p.

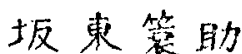
As 1. $\mathrm{PL738/.J61835}$

An annotated 11sting of classic kabuk1 dance plays. Dances are listed, by their comonly-known namea, In Japanese eyllablc order. Entries contain the following: type of malc, first performance dates and thester, complete name of the dance, namas of first performers, lyriclet, composer and choreographer, reprints and references, etc.

Rabukı buyō (Rabuki Dances) Ateumi Soltarō Tokyo: Sögensh 129 p. 111us. 歌舞伎 箈 踊

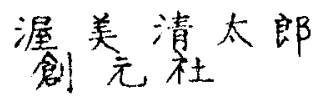
飤元, 1956 . AsLa PR2924.5/.A3AB

Gives laple explanatione of over 130 representative kabakl dances, noting the type, creation, changes, etc. of each dance. Nearly 100 pages of photo illustrations of the dances precede the texturl portion. This work to part of the Sögen Seneho Photo Ser1es.

Tabuk1 buyō no hansen (Trancition of Zebuk1 Dances) 歌舞伎舞踊9立要 Atrual Seltard Tolyo: Arueu $P \| Z$ 1942. 80 p. 111ue.

A. 1. PK2924.5/. 1348

A booklet of photo 11luetratione and explanation of famous kabukt dence playa. Describes the or 1 gin, changes, elgniflcance,

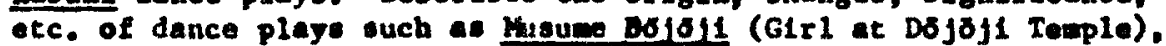
Benfleht (Lion Dance), Rune Benke1 (Benkel in the Boat), etc. 
Wnse1 Whon buyösh1 沂世日，本舞踊史 (Rocent Bletory of Japanesg Dances) Iahil Runiguki 石非国之 Tokyo: Tolto Bnge1 Taüghlocha 352 p. L11us. A1a CV1695/.I85

Bacorde the hietory of Japanese dances fron Ido Ran' ol perlod (1624-1644) to early Showa period (1926-). Describes the origin and evolution of varlous types of dances with eaphase on lubukt dances. Dellnates the genealogleal beckground and developinte of various schoole of dancing. Ragoge: 1977. 259 p. 111 lus.

中日新聞本勍編 Aá 1e GV1785/. 265134

Mahikawa Kolsaburö II, hesd of the Nishikawa School of dancing, recollects vatious anecdotes assoclated with his professional career which sanned Melj1-Taisho-Showa perlods. (Nationa1 Theater bur 8 Performance) rokuritsu Gokijō 国立㓟場 Tokyo: 19 Scettered 1seues.

Constitutes the program for buyd (Japanese dance) performances etaged at the lintional Theater In Tokyo. Containg explanatory comente on the dances, essays by dance critica, coments on dancers, etc.

rowaka bukyoku 幸若舞曲三十六種幸若八郎正本 (Lovake Dance Scripte) Iolkyo: Iyüko Shoin 汲古書院 1973. 2 v. A1: $12761 / .126$

Reduced photographic reproduction of the or 1 ginal manuecripte, in calligraphy, of 36 koneles dance pleces which flourlahed durins the age of civil war in Japan (late 15 th to late 16th centuries). The originale are in the collection of Raio Ualveraity Library. Blbllographle notations on the ecrlpte are given. 
Kyodo buy (Folk Dances) Kodere Yukich1 Tokyo: Hokusho Kankōka1 231 p. 111 us.
唧士 舞 踊

$$
\text { 小寺 融吉 }
$$

国書刑行会 1975 .

As 1a GV1695/.K568/1975

A compllation of hitherto unpublished esaaye by the author, Kodera Yük1chl, who is a ploneer is the flelds of folk dancing and folk arta. This work conelets of two maln eactions? 1) "Japanese Dances" which traces the bietorical developmente of varlous types of dances in Japan, and 2) "Bvolution of Dancing" which Interprets the flavor and igniflcance of Japanese dancing.

Kyoun1 京舞

1d. by Kyoto Shimbun Henghūkyoka

Ryoto: Tankōeha 淡交社

243 p. 111us.

Inoue Yachiyo IV relates the story of her lifetim with emphase on tralning and performances as a dancer. The Inou School of dancing was originated in the closing days of Tokngawe shogunate by Inous Sato, stater of the Confuctan scholar, Inoue Katsuke. Includes discussion of contemporary Syomel, the past and present of the Myako odor1, etc.
Mal no hon (Book of Dances)

Bd. by Matsuzawe Chisato

Tokyo: Koten Bunko

2 v.

Complete reprinte, in two volumes, of 32 codices titled Mal pe hon (Book of Dences) containing 33 kowake dance pieces. Codices are preserved In the Natkaku Library. Roprinted in block characters. Except for use of present-day kenjl charecters, in lieu of archaic characters, reprints are replican of the originals. Explanatory coments not included.

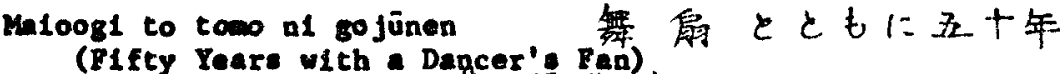
Puj10 Rantam 間 勘太女 Kumanoto: Whon Dang1ehe 日本䛲社 1975. 344 P. 111ue. Aola GV1785/.P7A35

An autoblography of a profesotonal Japanees dancer, Pujima Kantaw (1909-) ). Covere har lite and cereer from 1934 to 1973, with emphas is on her stage performances. 
686

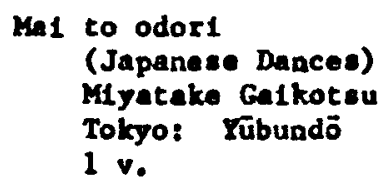

A collection of uklzoe dravinge, In color, of the Bdo perlod dances. Depicte 40 typer of folk dances, including hanael-odort (flower-vlewing dance). törē-mal (lantern dance). taue-odorl (rlce-planting dance), etc.

Hihon butōaht (History of Jepanea Dances) Lwahent Royata Tokyo: Kokush1 Köshüket $128 \mathrm{p}$. 岩橋小㤝太

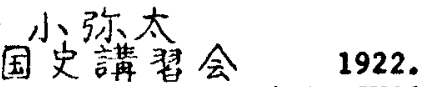

A sumary account of dancing in Japan, fron the anclent to aedieval ages, with focus on the changes in group dancing.

Introduces a number of well-known Japanese dances with as much 1llustrations as explanations. Dances Include the cleselc types appearing in kabuk1 plays, dances which originated in Kyoto, and new dances which becam popular after the Ka1j1 Bastoration. The author, himeelf, is a fanous dancer. (DLctlonary of Japanese Dances) Ed. by Gunj1 Mealicateu Tokso: Tokjodō 517 p. $111 \mathrm{ne}$. 東京堂 司正朕編 1977 . Aele Rnf. GV1695/.2425

This dictlonary covers Japanese dences of varlous types but emphase is placed on kabuk1 dances. Intries conteln the naw and type of dance, or 1 gin and date, performere and performances, achool of danclag, genoral and technical luterpretations, otc. Entries arranged in Japanese sileblc order. 
JAPANESE MANCX

Mthon buyōkyoku abūran $\quad$ 本繁踊曲集臨 (Collection of Japanese Dances)

Bd. b) Morij1 Icbirō

Tokyo: Sōshisha

606 P. 111us.

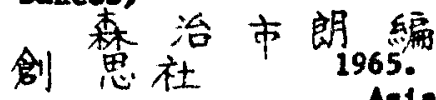

A collection of 772 pleces of dances covering the general renge of Japanese melc. Por each plece, preceding the song texts are headnotes, which explatn the dance, liet stage proparties and hand props used, describe costume and uige worn and note the time required for the dance place. (Handbook of Fanous Japanges Dances) Acakava Gyoluto Sumoto: Hōgakusha 拣 川王鬼 361 p.

Gives In a conc1se format, for 200 current Japanese dances, the interpretation, orlgin, stage presentetion, costumes, etc. for each. Includes background information to help understand Japanese dancing. (History of Japanese Dancing) Ishil Kuniyuk1 Tokyo: Ge1nō Bunke Rankyüikal 原茾 1962.

412 p. $111 \mathrm{us}$. 本舞踊の歴史 Sisrvey of the evolution of Japanese dances from ancient time to early 1960a. Covers the ourliest religious and Imparial Court dances and developoent of the noh dances. Emphas is is laid on the or 1 in of and changes in kabulat dance pleys. Concludes with discussion of the varioue schools of dancing which are st111 active today. (H1story of Japanese Dances) 踓史 Ataumi Sa 1 tarō Tokyo: Yüzankaku 284 p. 111us.

1958. AlL GV1695/.ABS

Explatne in simple, 1ayman's languege, the history of kabuki dence plays. Intended for entertaining reading. 
Nibon buyō ōran 日 本舞踊総管

(Comprehenalve Survey of Japanese Dances)

Rd. by Nihon Buyō Ryōkal

Tokyo: Whon Shưōahe

443 p. $111 \mathrm{us}$.

日本週報社

踊協会編

Introduces Japanese dences, In general, wh many photo 1lluatrations. Comprised of four sections: source naterials, interpretations, directory of Japenese dancers and handbook. Appears to have the comblned format of an encyclopedia and an annual.

Mhon klnsel buyōah1

(Racent Hietory of Japanese Dances)

Kodera Yük1ch1

Tologo: Tuzankakv

小寺高虫吉

382 p. 11lus.

1931.

As 1e GV1695/.R63

Relates the developwent of dances in kabukt playe with emphas is on the Edo perlod. Includes a survey of popular dancers in Edo, Kyoto and Osaka and folk dances in the rural areas. Comente on the characters of fanous dancers of the recent pest.

Nhon koten buyō no kenkyū (Study of Classic Japanese Dances) Nakamura Ak1Ich1 Tokyo: Kusakabe Shoten 442 p. 111us.

Traces the historical flow of Japanese dances from kagura (Shinto dance and music) of anclent times to ayatsuri ningro (puppet shows) and explaine the1r relationohips with kabuk1 dancing pleys. Aleo, Interprete the relationahlp between mulc and dancins.

Alinon no odori (Japanece Dencing). Kubota Kinsen Tokyo: Shimbt Shoin 238 p.

$\Delta$ history of Japanese dancing from ancleat tios till the birth of modern kebuk1. Delineates genealogies of dencers and choreogrephers who energed during the Edo perlod. Describee, In general out11ne, the transition of Japanese danclag.
1937. Asia GV1695/.1282 
Memolrs of Azum Tokuho, publiehod to commonorate recelpt of the Art Acedemy award. Tha author, who is a profeselonal Japanase dancer, recollects her life and thatrical experiences and accouplishments.

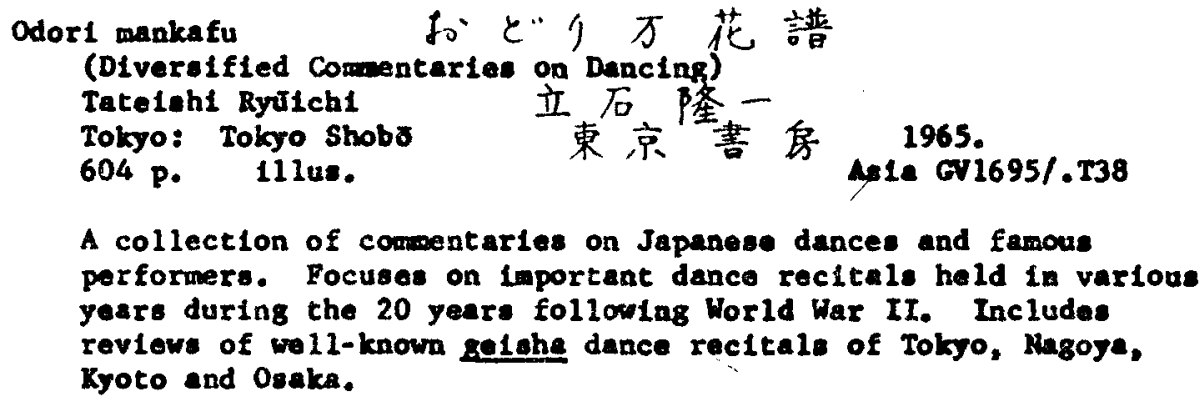

A treatise on aesthetic consideratione of Japanase dancing. Focuses on the eigatficant role of dancing in the developient of theatrical erta in Japan.

Odorl no kodōgu c と”y 小道县

(Hand Props for Japanese Danclas)

Aral Tunij1rō, Rodera Yükichl and Mrao Shigeo 新井国次郎 小寺融吉，宫尾( け“老

Tokyo: Nōgaku Shorin 能浆書林 1953.

288 p. 11lus. Aala G1695/.1587

Sarves as reference on hand props uead in Japanees danclag. For different dance pleces, showe oketches of dancere and gives the type, color, shape and tandard mesurements of the hend props. Bxplains usage of the prope. 
JAYARSB DAMCE

702

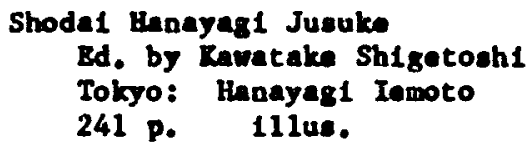

初代花柳寿輔

花柳家繁俊編。

241 p. 111us.

花柳 家 充

A blography of Hanayag1 Jusuke I (1821-1903), founder of the Henayag1 School of danclos, complled on the occesion of the 33rd enntvereary (1935) of his death. 


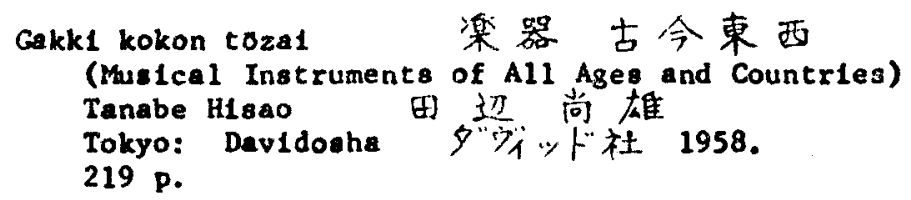

The author discusses the musical Instruments of Japan an well as those of the West and the East.

Genj1 monogatar1 no ongaku源代物語の音楽

(Music in the Cenji Monogatar1)

Yamada Takao 山田孝雄

Tokyo: Hōbunkan 宝文館 1934.

1 v.

As 1a PL788.4/.643Y353

A comprehensive selection of all articles concerning music from the Genif monogater1 (Tale of Genj1). The articles were f1rst arranged and classifled, and then, explanations were added. Furthermore, as comparative references, articles are included on muslc from Makura no sōshi (The P11low Book), published during the game period, and from the Helke monogatarl (Tales of Helke), published during a later perlod.

Hōgaku e no shōta1

(Invitation to Japanese Music)

Kikkawa E1 sh1

Tokyo: Hobunkan

宔文凔

$447 \mathrm{p}$.

As 1a ML340/.K561

Alms to broaden the understanding of Japanese music, in general, and discusses 1ts history and appreclation In layman's language. Divided Into two main parts and an auxiliary section. Part 1 covers chronolog1cally, from Edo perlod.to Showa period, the development and changea. Part 2 also cover chronologlcally, for the seme perlod, the apprectation of the various types of Japanese music. The auxillary section discusses the history and appreciation of gagaku (court music), yolkyolku (noh chants) and shinna1-bush1.

Hōgaku metkyolku höten

邦楽启曲宝. 典

(Treasure Book of Famous Japanese Songs)

Ed. by Shinkō Gakufu Henshūbu

Tokyo: 1952.

$1 \mathrm{v}$.

新然然譜編集部编

As 1. M1812/. 164 
JAPANESE MUSIC - GENERAL

Selections of 345 songs, Including nagauta, hauta, kouta, k1 yomoto, ryūkōka, etc.
Högaku no tomo
(Friend of Japanese Music)
Tokyo: Hōgaku no Tomo Sha

1970-1980 (v. 16-26)
䢶架之友社

As 1a ML5/.H63

A monthly perlodical for those with interest in Japanese music of all types, including nagauta, kouta, koto music, etc. Contains news, reviews, comments, announcements, etc. pertaining to Japanese music.

Hōgaku talke1 邦楽大系

(Outline Account of Japanese Mus1c)

Tokyo: Chikuma Shobō 筑摩書房 1970-1972.

$13 \mathrm{v}$. 11lus. Asla X FO M.340/.H64

A collection, in 13 volumes, presenting an overall view of Japanese music. This collection is unique in that LP phonograph records of the music described are Included in each volume. Vol. I covers gagaku (court music), Buddhist music and blwa (Japanese lute) masic. Vol. 2 covers noh and kyogen, Vol. 3, koto (Japanese z1ther) music, shakuhachi (flute), etc. In addition to the phono records, each volume contains photo 1 llustrations, historical articles and explanations Intended to deepen appreciation of the particular form of music.

Hogaku yögo flten

(Dictlonary of Music Terminology)
Tanabe Hisao

Tokyo: Tokyodō Shuppan

199 p.

束京堂出版

1975.

Asta Ref. ML100/.T3

A dictionary presenting simple, concise definitions of terms used in Japanese music. Arranged by Japanese syllablc order. (Brief Hiatory of Music, Dancing and Drama) Konakamura Riyonor 1 Tokyo: Yoshikawa Hanshich1 2 v. 小中村清矩

1887.

Asia ML3451/.J3R65

An outline history, In two volumes, of Japanese performing arts. Covers, in general, from ancient times to end of Edo period. Relates the introduction of music from China and Korea, origin of native music and dances, including noh and kabuk1, evolution of mustcal instruments, etc. 
JAPANESE MUSIC - GEHBRAL

711

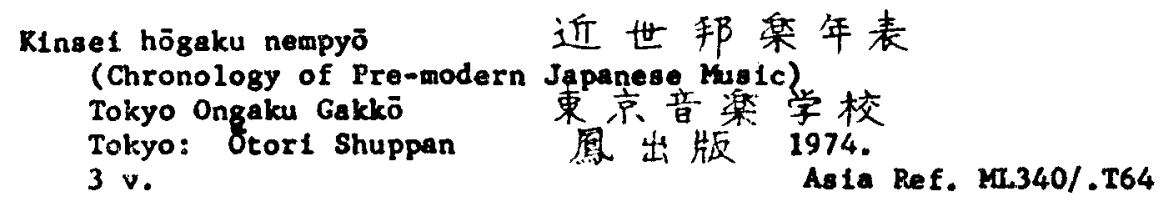

A chronology of performances by the various school of Japanese music since the days of their initial formation under Reis 3 (1867). Gidayũ performances are listed for theaters in the three cities of Osaka, Kyoto and Edo but the other are recorded for Edo only. Vol. 1 covers, "Toklwazu, Tomimoto and Kiyomoto Shools." Vol. 2 consista of "Edo Nagauta with O-Satguma Jorur1 Appended." Vol. 3 discusses "Gldayu-bush1."

1943. As 1a ML340/. I88

Compilation of various treatises by the author on anclent Japanese music. The main subject of study include: kaqura (Shinto ritualistic mualc and dance), ancient musical instruments, the national anthem (KIm1gayo), gakubu, etenraku, etc.

Tenri Dalgaku 天理大学

Tenr1: 1974. 494 p.

A collection of $s i x$ representative, old documentary reproductions, closely related to classic Jepanese music, in the custody of the Tenri University Library. Annotations are given at the and of the work.

Kokuritsu Gekijō hōgaku kōen 国立虔場纬染公演 (National Theater: Japaned Tokyo: Rokuritsu Gekijō 1971-1976 (nos. 12-25)

国 II 尉埸

A collection of 13 printed programs of Japanese music performances held at the National Theater In Japan between 1971 and 1976. Printed programs are for the 12 th through 25 th performances of the series (Note: Program for the 16 th performance mise1ng). 
JAPARESB MUSIC - GENERAL

715

Kokuritsu Bekijö Nihon ongaku no nagare

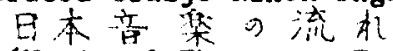
(National Theater: Trend of Japanese Music) Tokyo: Rokuritsu Gekijo 国㓺增 1975-1976. 3 v. (nos. 1-3) Asta PN2924.5/.K3K648

A compliation of three printed programs of the series, "Trend of Japanese Mus1c," held et the National Theater in Japan. The first performance, January 1975, featured koto (Japanese z1ther), second In October 1975 was on gldayü, Joruri, etc., and the third, October 1976, presented blwa (Japaneae lute).

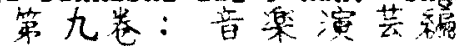

(Me1j1 Period Cultural History, Vol. 9, Music and Theater)

Ed. by Komlya Toyotaka

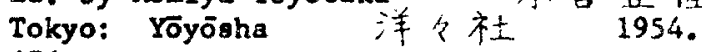

676 p.

曹隆編

A compllation of essays on Japanese music and dance and Festern music by several noted critics. Articles and authogo are as follows: Me $1 j 1$ muslc and theater by Komiya Toyotaka, gagaku (court music) and noh by Furukawa Hisashl, bunraku (puppet theater) by Miyake Shütarō, theatrical arts by Toita Yasuji, Japanese music and dance by Machida Kashō and Western music by Nomura Köichl.

(Story of Melj1 Period Music)

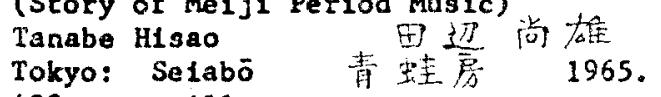

420 p. Hilus. As1a ML340/.T34

Random essays by the author on musical development, personalities and personal experiences from 1860s to 1920s. Comprised of three parta. Bart 1, "From End of Shogunate to Early Meif1 Perlod," descrlbes popular songs, including chobokure-busht (ballads of treet troubadours), and rakushu (lampoons) of the perlod. Part 2, "Melj1 Personalites and the Author," discusses theatrical performers and transitions in songs and performing axts during the Melji. period. Part 3, "Story of Melj1 and Talshō Perlod Muslc," relates musical developments, Including the oudden rise in popularity and reputation of neniwa-bushl (storytelling ballad) in the 1890s. There 18 a closing chapter revealing the personal life of the author. (Study of Traditional Music of Japan) Kolzuml Fumio 小集文文 Tokyo: Ongaku no Tomo Sha 253 p.

音梁之在社 1958 As 1a ML340/.K7 
JAPANESE MUS IC - GENERAL

The author views folk songs and children's songs as forming the fundamental bases of Japanese traditional muslc. Through introduction of the European and American methodology of studying folk congs, a new approach to the study of Japanese folk songs is being contemplated by the author.

Nhon föko ongakusht (History of Ancient Japanese Music)

Sanjō Shōtarö

Tokyo: Kösetkakı 436 p.

$$
\text { 日本上古音罵史 }
$$

$$
\text { 三佟商太、蚛 }
$$$$
\text { 愿生翼 }
$$

1935.

As 1a $\operatorname{ell} 340.2 / .535$

A study of the ancient music of Japan with emphasis on music introduced from ChIna and Korea, and their Influences on the tonal system of Japanese music, and on the historlcal development of kagura (Shinto ritualistic music). There are also brief discussions on mikagura (Shints music at the Imperial Court) in the post-Melj1 Restoration period and instruments used in kagura mesic.

(Historical Study of Ancient Japanese Music) Hagi Mitsuo 荻美津夫

$$
\begin{aligned}
& \text { Tokyo: Yosh1kawa Köbunkan 吉师弘文館 } 1977 . \\
& 283 \text { p. Asla Ma3750/.04 }
\end{aligned}
$$

A historfcal analysis of the role of music in anclent Japanese society and transitions in the musical establishments, instruments, performers, etc., particularly in the fleld of gagaku (court music).

(Japanese Musical Instruments)

Tanabe Hisao

Tokyo: Söshisha

由迎尚雄

381 p. 11lus.

制思衤

1964.

As La Ref. ML535/.T36

A reference book on the types, features, uses, etc. of Japanese musical instruments. Part 1 is on classical Japanese instruments presentiy in use. Part 2 1s on instruments altered or newly designated In the post-Mle1j1 period. Part 3 covers old instruments which are no longer in use today. Part 4 describes instruments which are used only for speclal purposes. Part 5 takes up accessories for musical Instruments.

Nithon no ongaku

(Japanese Mus1c)

Kanetsune Kiyosuke

Tokyo: Rikugokan

508 p. 111us.
日本的音泉

$$
\begin{aligned}
& \text { 萧常湆作 } \\
& \text { 六命舵 } 1913 . \\
& \text { As 1a M.340/. K35 }
\end{aligned}
$$


JAPANESE MUSIC - GENERAL

A detalled study of the hlstory, theorles and values of Japanese music. Emphasis is la1d on Helke blwakyoku (chanting of Tales of Helke to Japanese lute accompaniment) and lluta (referred to by author as kamigatauta or songs of Kyoto-0saka areas). The study also covers different types of Korean music and muslcal theortes of China.

Nihon no ongaku (Japanese Mus 1c)

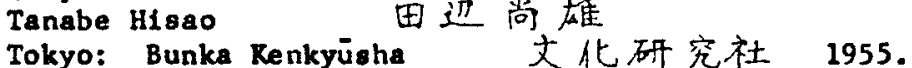

337 p.

As 1a MC $340 / . T 354 / 1955$

An analytical survey of the various types, characteristics, tonal system, theories and performances, etc. of classical Japanese music. Types of music discussed Include gagaku (court music), Buddh1st music and instrumental music of shamisen, blwa (Japanese lute), shakuhachl (flute) and koto (Japanese zither).

Nihon ongaku $\quad$ 本音楽

(Japanese Mus 1c)

Fujita Shun'1chi

Tokyo: Nihon Ongakusha

v. 2-18.

藤由俊一

日本音然社 1947-1963.

A periodical mainly featuring koto (Japanese zither), shamisen and shakuhach1 (flute) for readers with interest in Japanese classical music. Published every 2 months.

(Outline Study of Japanese Mualc)

Iba Takashi 伊庭孝

Tokyo: Rösetkaku Shoten 厚生闊書店 1928.

999 p. 11lus. Asia M340/.I232

A study of Japanese music, utilizing time-honored Japanese documents and applying research methods of Western music. Conelsta of three parts. Part 1 discusese the tonality and rhythm of Japanese music. Part 2 describes Japanese instruments and playing methods. Part 3 notes the developmental stages of Japanese music.

(Lectures on Japanese Music)

Tanabe Hisao

由这尚雄

Tokyo: Iwanaml Shoten

764 p. $111 \mathrm{~s}$.

岩波書店 1919 .

As 1a M340/.T353 
Examines the characteristice of anclent Japanese music being transmitted by the Music Department of the Imperial Household Agency. Explains the histortcal developnent of music in Japan.

727 Nihon ongaku no chösh1 no hanashi $\mathrm{B}$ 本音准9謂子9話 (Story of Tonality of Japanese Music) SanjōShotarō 三條商太郎 Tokyo: Kose1kaku 1932. $374 \mathrm{p}$. As 1a ML.340/.5355

Through comparisons with Western and Chinese music, explains in detall the musical theories and characteristics of Japanese music.

Explains the historical development and characteristics of Japanese music. ages, in chronological order by the different historical perlods. Also discusses Christian and Western music.

A spiritual appraisal of the qualities that make up Japanese mualc. Discusses the Confucian concepts of proper conduct and gentlenese of opirit that influenced the development of Japanese music. Analyzes Buddhist influences such as rigorous spirituel training in the educacion of performers, considers the principles of harmony, respect, purity and quietude, as reflected in the tea ceremony, and their Influences on Japanese music. 
JAPANESE MUSIC - GENERAL

731

Whon ongakush1
(History of Songs in Japan)
Tba Takash1

Tokyo: Sh1nkō Ongaku Shuppanshs

191 p.

新無音染出版杜

As ia ML340/. I23
1942.

With the focus on kayō (Japanese songs), records the birth and development of various types of songs within the Japanese historical context.

Nihon ongaku to sono shūhen 日本音秝ととの周辺 (Japanese Music and Its Surroundings)

Bd. by Kolzumi Pumio 小泉文夫編 Tokyo: Ongaku no Tomo Sha 808 p. 音舁之友杜 As1a ML340/.K73

A collection of essays, In Japanese and English, on music of Japan and adjacent countries, primarily China and Korea. Subjects covered in Japanese essays include musical character of rice-planting songs on Tokunoshima Is land, "11ge" In Shingon sect Buddhlst chants, research on "dan-mono" of koto music, scale and melody of Japanese music, etc. There are articles on the study of "Chul-Chaf" songs of China (in Engl1sh) and a study on rhythm of Korean music. Slace this work commemorates the kanrek1 (60th birthday) of Professor Kikkawa E1shi, there are congratulatory messages, his blographical sketch, his writings and accomplishments, etc.

Nhon senritsu to wasel

日本葆律と和声

(Japanese Melody and harmony) Bōda Kazuma 㧍由帮真 Tokyo: Ongaku no Tomo Sha $161 \mathrm{p}$. 音隼之友社 1966 . As 18 M.340/.B63

A detalled explanation, from many standpointa, of the author's theory on Japanese melody. The author had personally gathered and used as his source materials, the melodies of country songs lncluding folk songs, children's songs, etc. Emphasis is lald on analysis of the scale, cadence and modulation. Explanation is aloo given of the Japanese harmony based on the melody patterns.
思出 の邦隼人

(Recollections of Japanese Musfal Personal1t1es)

Tateno Yosh1j1

Tokyo: Me1j1 Shoin

$343 \mathrm{p}$.
舘里予善二

明治暴院 1974 .

A. La M385/.T28 
JAPANESE MUSIC - GENERAL

Profiles of Japanese musical personalities depicted by a TBS (Tokyo Broadcasting Service) officlal, In charge of Japanese music on radio, who actually came to know them through his work. A 11 ght egsay but reveals vividly tho artistic talents and personalities of auch performers and critics as Takemoto Tsunadayū, Tokivazu Mojibel, Myag1 Michio, Ando Tsuruo, et al. A compliation of entertaining articles which had been published from June 1971 in the monthly per1od 1cal, Hōgaku no tomo (Briend of Japanese Mus1c).

(Mus1cal Arts)

Tokyo: Ongaku no Tomo Sha 音渠之友杜 1957-1980.

v. 15-38.

As1a ML5/.054

A monthly perlodical covering events, reviews, commentarles, roundtable discussions, etc. in the Japanese musical field. Also discusses Western musical trends, highlights of muslcal/happenings overseas, etc. A magazine devoted to readers with taste in the more classic, rather than popular, type of music.

Ongaku gojūnen 音楽五十年

(Fifty Years of Music)

Sonobe Saburō

園部三蚛

Tokyo: Jij1 Tsüshinsha 時事通信杜 1950.

393 p.

As LE ML340/.S65

Explains how Japanese music changed and developed with historical events between 1901 and 1950 . The author claims that with the demise of feudalism and birth of modern Innovations in Japan music was also affected and forced to change. This work 18 an attempt at historical and cultural evaluation of Japanese music.

Ongaku gojūnen sh1 (Fifty Years of Horluch1 Kelzō Tokyo: Masu Shobö 309 p.

$$
\text { 音染五十年史 }
$$

$$
\begin{aligned}
& \text { 堀内敬三 } \\
& \text { 魯尊書房 } 1948 .
\end{aligned}
$$

As 1a ML340/. 1767

Depicts the changes and transitions in music of Japan between the Melf1 Restoration (1987) and early Showa period. Notes the rise and fall of Japanese and Western music and analyzes che political, social, economic, cultural and International factors, which directly or Indirectly influenced the musical vicissitudes.

$$
\begin{aligned}
& \text { Ongaku fiten 音楽辞典 } \\
& \text { 堀内敬三匹他了编 } \\
& \text { 音染之友杜 } 1962 \text { 。 } \\
& \text { As ie Rof. ML100/.05 }
\end{aligned}
$$


JAPANESE MUSIC - GENERAL

Consists of two volumes, one on musical terminology and the other on personalities. Vol. 1 on terminology contains information on typea of Japanese and foreign music, definitions of terms, explanations of Instruments, etc. Arranged by Japanese syllabic order. Includes a subject Index In Japanese and forelgn languages. Vol. 2 on personalities has falrly detailed blographles of composers, performers, etc. Modern Japanese musiclans are included but personalities associated with class Lc, traditional Japanese music are excluded. Arranged by Japanese oyllabic order. Appended 18 an Index of names In English and forelgn languages.

Ongaku jiten 音集辞典

(ausic Encycloped1a)

Tanabe Hisao and Kikkawa ElshI Tokyo: Helbonsha 平社

田近的雄，吉师英史 1954: 1958 . $12 \mathrm{ve}$ As 1a Ref. ML100/.048

Consiste of 11 volumes and one volume (v, 12) of indexes. Arranged by Japanese syllabic order. There are personality and subject indexes In Japanese and foreign languages. Comprehensive and detalled, covering the music of the world. Emphasis is on Japanese music. Contalns information of a general nature, including scale, inatrumenta, etc. (One Hundred Years of Music Since Meij1 Period) Horfuch Ke $1 z \bar{o}$
Tokyo: Ongaku 堀内敬三 Tokyo: Ongaku no Tomo Sha 352 p. 111us. 音湟之友社 1968 . As 1 a ML340/. 1672

Records the changes and transitions in music in Japan during the 100 years since the first year of Helfl period (1868). Pays particular attention to the rapid acceptance and absorption of Western music and by contrast, the low growth of Japanese music.

An annual of the year's events and a dictionary of parsonalities and organizatione in the fleld of Japanese and Hestern music. Consise of four parts. The first part, "General Summary of Musical World," records the highlights of the year in various musical sectors, such as composing, recordings, choruses, gagaku (court music), Japanese dancing, etc. The second 1s a "Roster of Music-Affillated Personalitles." The third 1s a lieting of "Music-Affiliated Organizations," and the fourth, announcements of newly published books, references, etc. on music. 
JAPANESE MUSIC - GENERAL (Appreclation of Japanese Mus 1c on Radio) Machlda Kashö 町田嘉章 Tokyo: Hōsō Shuppan Kyōka1 枚送出版協会 1950 . 327 p.

Serves as a handbook to appreclation of Japanese music broadcast on radio. Comprised of three parts. Part 1 presents background Information on Japanese music. Part 2 explains the different types of music, Including gagaku (court music), blwa (Japanese lute), shakuhachl (flute), etc. Part 3 clasalfles Japanese music by different categorles such as Döföti-mono (Döjöjl Temple music), michiyuki-mono (love sulcide mus1c), Kanjlnchö-mono (Subscription L18t malc), etc. As appendices, there are "Glossary Abstract of Japanege Musical Terminology" and "Simplifled Lineage Charts of Japanese Musical Performing Arts". Techniques)

Matsudalra Yoritsune

Tokyo: Ongaku no Tomosha 新架之友杜 1969.

407 p. 1llus.

A study of the musical scales, melodies, etc. of Oriental and Western music. In essence, a technical manual explaining composition techniques. Chapter 4 is devoted to Japanese music. Types of music described include gagaku (court music), salbara, shōmyō (Buddhist chant) of Shingon and Tendal sects, gökyoku (Japanese zither music), shamlsen music, blwa (Japanese lute), etc.

744

Shōsōin gakk1 chōsa gâhō

正倉院染器調查概報

(Survey Report on Musical Instruments in Shösōin)

Shiba Sukehiro

Tokyo: Kuna1chō

3 v. 11lus.

1951-1953. As 1a DS801/.J368

This report, complled by the four authors between 1948 and 1952 , covers musical inetrumente in the Shöbin, the Imperial Ropository In Nera. With photographic 1llustrations, this survey prosents detailed descriptions and measurements of 18 types of musical instruments, most of which reportedly date back to the 8 th century or earller.

Shōaס̄ı gakk1 no kenkȳi 正念院染器の研究 (Study of Musical Instruments in the Shosठ1n) HayashI (Nagaya) Kenzō Tokyo: Kazama Shobō 370 p. 111us. 林[長坔了謨三

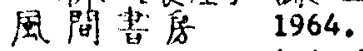
370 P. 11lus. Asia ML535/.N3 
JAPANESE MUSIC - GENERAL

Through examination of varlous types of source materials, including the musical instrumento still stored In the Shösoin (the Imperial Repository in Nara), the author attempts to recreate the music of the distant past.

(Musical Instruments in Shosōin) Ed. by Shōsōin IE 倉院 編 Tokyo: Nihon Kalzal Shimbunaha 234 p. 11148 .

日本経消新聞社 1967 。 Asia ML535/.S56

A complete coverage, with explanations and lllustrations, including color photos, of musical Instruments in the custody of Shosoin (Imperial Repository in Nara). There are essays on "Background History and Present Status of Musical Instruments in Shōsōin," "Investigative Study of Musical Instruments in Shōsōin," etc. Furthermore, there is an English article titled, "Muslcal Instruments In the Shosoin," at the end of the work.

Töa ongaku ronsö

(Essays on East Asian Music)

Ed. by Kishibe Shigeo

Tokyo: Yamalchi Shoten

890 p.

東要音渠論菲

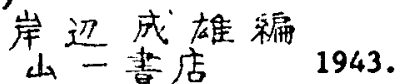
As 1a YL $330 / . K 58$

A collection of over 30 essays on Japanese and Orlental music, written by the ex-students and colleagues of Tanabe H1sao in commemoration of h1s 60th birthday. Tanabe Hisao is a noted critic and authority on East Aslan mus1c. Bssays include "Mustcal Performances of Rabukl," by Kawatake Shigetoshl, "On the SIgnificance of Chinese Bugaku," by Tak1 Ryölch1, etc. Subjects cover a wide fleld of Japanese music and the musical styles of China and Korea.

(Journal of the Soclety for Research in Aslatic Music) Ed. by Toyo Ongaku Gekka1 Tokyo: Ongaku no Tomo Sha nos. 9-15. 東洋音渠学会編 音菜之友社 1951-1958. As 1a ML5/.T6

As the title states, this publication 18 an academic organ of the Soclety for Research in Aslatic Music, founded in 1936 in the Tokyo University of Art, Department of Music. The publication 1s Irregular, with No. 9 appearing in March 1951, 10-11 in December 1952 and 12-13 In September 1954. The latter 18sue 18 a special edition on shomy (Buddhlet chant). There are a number of articles in English, e.8., no. 9 contains "Two Problems: Sangaku or Sarugaku," by Hayash1 Kenzō, "Wind Instruments of the Alnu," by Tarō Öt, "On the P'1-p'a or Chinese Lutes," by Tak1 Ryôtch1 A scholarly journal on Asiatic music. 
MUSICAL INSTRUERTS

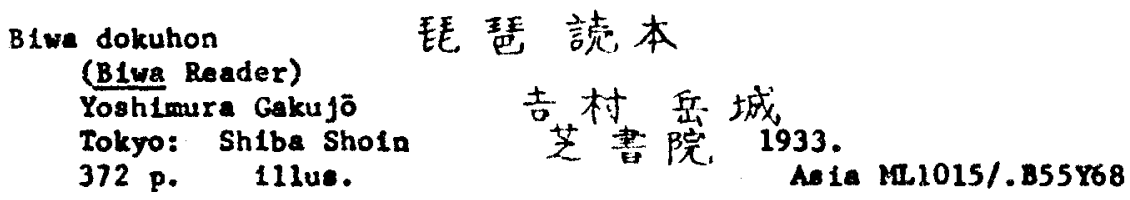

A reference book on the biwa (Japanese lute), Including history of the Satsum blwa, Instructions on 1ts playing, singing of blwe songs, etc.

Biwa zenshü 琵琶全集

(B1we Collection)

Ed. by Nakauch1 Chöj1 and Tamura Nish1o

Tokyo: Nihon Onkyoku Zenshü Kanköka1

1927.

487 p. (M1hon onkyoku zenshü, 5 日本音曲全集，5) Aeia M 340/.N55/v.5

A collection of the words to 102 blwa (Japanese lute) songs of the Satsuma and Chikuzen schools. Brief headnotes are given for each song. Arrangement 1s by Japanese syllable order. A conclse history of biwa songs and an Index are Included at the end of the work.

751

Bugaku zusetsu 隼目説

(Illuotrated Book of Court Dance Music)

Kawabata Sanehide 河踏実英 [化]

Tokyo: Melj1 Tosho 明治国㶳 1957.

249 p. Lllus.

A compllation of photographs of old bugaku (court dance masic) pictures of the Musc Department, Imperial Household Agency. Detalled explanatory notes presented. Instruments, costumes, maks, etc. are aloo shown.

A publication, in two voluses, of explanatory notes and remarks on 11lustratione of bugaku (court dance mustc). Vol. 1 containa explanatory notes on eamel (left dance) which was introduced from China, as well as remarics on history, kinde, terms, etc. of bugaku. Vol. 2 containe notes on umal (right dance) which wes introduced from Korea. This work is an orientation guide to bugaku. 
MUS ICAL INSTRUMENTS

$$
\begin{aligned}
& \text { Bueō gafushū 挴等雅請集 } \\
& \text { (Collection of Koto Song Textg) } \\
& \text { Tokyo: Bdo Shorin 江卢青, 林 } 1009 \text { 。 } \\
& 3 \text { v. }
\end{aligned}
$$

A collection, in three volumes, of the song texts of the Ikuta school of koto (Japanese zither) walc.

Gageku

(Court Mus 1c)

Ed. by Söshieha

Tokyo: 1973.

266 P. 111us.

創思社編

准

Primarily, a follo-sized album with 245 plates of color photos presenting a vivid, comprehensive portrayal of gagaku (court mue1c). Falrly detalled explanations of the photos are given. Covers different types of dances, musical instruments, costumes, masks, accessories, etc. Also Included are articles in both Japanese and English on the appreciation, historical transition, etc. of gagaku. The four genres of gagaku are discussed: kangen (instrumentel ensemble), bugaku (court dance music), saibara and röel (songs), and kagura (ritual music for Shlnto ceremonies).

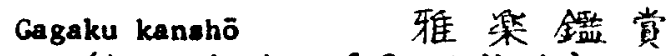
(Appreciation of Court Music) Oshide Yoshihisa 抻时良久 Tokyo: Bunkendō Sh1ch1se1sha 306 p: 111 e. 文害堂七星社 1969 。 As 1a ML340/.082

D1scusaes, In layman's language, the varlous facets of gagaku, the enclent court mulc of Jepan. Gegaku Includes the genre of Fritual molc for Shinto cerenonies," which has four major parts derived from ancient native music: kagure, Yenatomal, kuegna1 and azuma asob1. Gagaku a 180 includes the maln genre of bugaku (court dance mus1c), whlch developed from Tögaku, the art mustc and dance of the $T^{\prime}$ ang dynasty court, and Romagaku, malc of Korea, both of which were introduced to Japen around the 7 th century. Th1s work also denotes the Instrumentation and the accospanying dances for the different pleces. 
MUSICAL INSTRURENTS

\begin{abstract}
A collection of essays, which examine from various standpoints, Orfental malc with the focus on Japanese was1c. Emphasis is lald on recreating the old image of gagaku (court maic) through atudies of anclent music sheets.
\end{abstract}

757

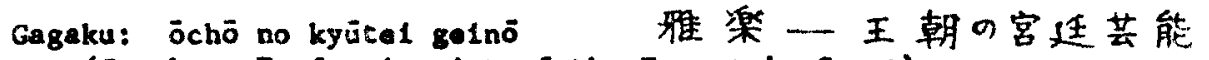
(Gagaku: Performing Art of the Emperor' Court) Ed. by Celnōshi Kenkyuika1 芸能史研究会䋧 Tokyo: Helbonsha 平风社 1970 .

380 p. 1llus. (Nihon no koten geinō, 2 日本a古典芸能, 2) As 1a $\mathrm{PN} 2921 / . \mathrm{N} 53 / \mathrm{v} .2$

Traces the historlcal background and traditions of gagaku (court mus1c). Records that gagaku did not simply remain an important cultural art but through Imperial patronage, was assimilated and reorganized to sult the Japanese tastes and customs and developed into a native perforwing art.

758

Gagakushu 雅渠集

(Court walc Collection)

Tog1 Bunrel

Tokyo: Hōmeikat

東儀文礼

1934.

$3 \mathrm{ve}$

As 1a ML 340/.T64

A collection, In three volunes, of musical notations for and explanations of the secret arts of playing gagaku (court music) 1nstruments. Vol, 1 is on höshö (mouth organ), Vol, 2 on ryütek1 (flute) and Vol. 3 on hlchirlki (oboe).

Gagaku sōfu 雅 桨 総 譜

(Musical Scores of Japanese Court Music)

Shibs Hiroyasu

Tokyo: Ryüginshe

2 v. (v.1-2).

111us.

枯寒探譜

龍吟社 $1955+1956$.

Musical scores and explanations of gasaku (court melc) in two volumes. Vol. 1 covers gagaku orchestral mulc and Vol. 2, salbare (according to the author, orlginally a kind of anclent Japanese folk song edapted to Imperial court music). The explanatione are translated into English and French. The poems have Romanited readings with Baglish and Brench translations.

Tokyo: Zenongakufu Shuppan 全音贸譜出版 1953. $100 \mathrm{p}$. 
MUS ICAL INSTRUMENTS

An experimental, orientation gulde ut1lizing the five-gtaff Western musical sheets for the Japanese shamisen which had not, heretofore, employed mustcal scores.

761

Inutaryū kinkyoku uta no unl 生时流琴曲歌之海

(Collection of Ikuta School of Koto Music) ${ }^{7}$

Ishida Ijürō 石田猪干郎

Kyoto: Ogidō 尾木堂 1889 .

2 v. $(v .2-3)$. As 1a M142/.K6185

A colloction of koto (Japanese zither) songs of the Ikuta school of koto meic.

Issoryū fue yub1zukeshü - 增流笛指附集

(Plogering Instructions for Isso School Plute)

Ed. by Morlkawa Sōklch1 森川荘吉公

Da1ren: Ich1fukal -- 樹会 1944 .

$53 \mathrm{p}$.

As 1a M $990 /$. R9M67

A book of Instructions on basic fingering movements for the nogaku fue-lutea (noh flutist) of the Isso school.

Issoryü hōkashū - 噌流唱 歌集

(Collection of Isso School Songs)

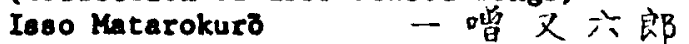

Tokyo: Wan'ya Shoten Whや轱店 1953.

2 v.

As 1a PN2924.5/.N6I86

A collection, in two volumes, of flute songs of the Isso chool nogaku fue-kata (noh flut1st). Examples are Matsukaze (P1ne Wind or Three Sisters on the Seashore), Ataka (Ataka Barrier Gate), etc.

Rabu himinoku

歌儛 品 目

(Gasaku Glosary)

Ogewa Morinake 小川守中 $\mathrm{Ed}$. by Masamune Atsuo 正宗敦夫編 Tokyo: Nihon Roten Zenoha Kankoke1 日本古典全稟利行会

1930.

2 v.

As 1a Mn340/. 224

A detalled gloseary, In 10 volumes (12 lesues), of gegeku (court mus 1c) terminology with quotations from original materialo. Roprinted in block charactera. Complled by Ogawa Morinaka in 1822 or prior. A valuable reference for seclalists and orientation gulde for beginnera. 
NUSICAL IMSTRUMENTS

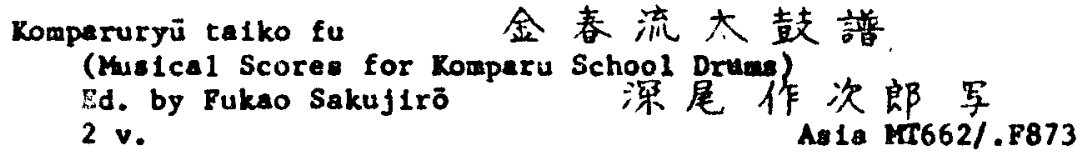

Practically an Identical version of the Komparu taiko fusuke (Husicel Scores, with Notations, for Komparu Schoole Drume). Notatlone have been added to various plays of Romparu school noh texts and Instruction. on playling the talko (atlck drums) have been Indlcated in red.

Musical scores with notations for various plays of the Komparu school noh texts.

A reminder of instructional hints for practices of the talko (stick drum) of the Romparu school of noh drama.

Explains the molcal theory behind taiko (atick drums) used in noh drama. Gives practical instructions on hov to play the drums.

A complilation, In two volumes, of musical scores for different pleces, classifylng and noting the hand movements used in the ro school of nögaku kotsuzuml-kata (noh shoulder hand drum player). Ko is one of four such existing schoola. 
MUS ICAL INSTRLENTS

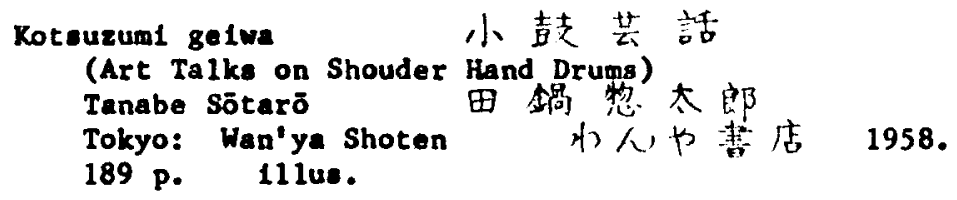

Comprised of three parts. Part 1 is a presentation by the author, wo to noted player of kotsuzuml (ohoulder hand drum), on the bastc knowledge of kotouzumi. Part 2 consists of art talke, Including the author's recollectlons of noh atage appearances and the role of kotsuzumi in different noh plays. Part 3 is a memolr of 60 years of stage performances and history of the noh world of Nagoya. A good reference on koteuzumi and 1 ts role in noh performences.

Kotouzum1 to tomo $\mathrm{nI}$ 小款と厄纪

(Together with the Shoulder Hand Drums) Rō Yoshimitsu 辛祥光

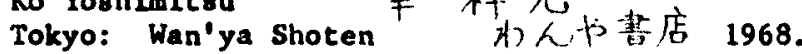
241 p. $111 u 8$.
As 1 a P M $19 / . \mathrm{K} 6$

An autoblography, Including art talke, of Kō Yoshimitsu (1892--), head of the ko school of nōgaku kotsuzuml-kata (noh shoulder hand drum player). A detalled performance chronology (1904-1968) of the author 1s appended.

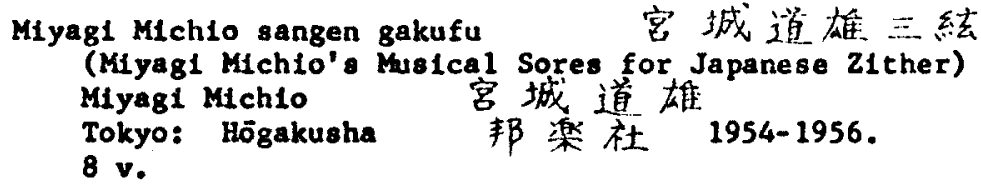

A collection, In elght volumes, of Miyagl Mich1o's musical scores for sangen (Japanese zither). Includes favorite pleces such as Rokudan-noshlrabe, Shōch1kubal, etc.

Nihon gakudō sōsho

(Japanese Musc Ser1es)

Ed. by Hazuka Ratwel

Nagoya: Gakubu Konkyūkat

$12 \mathrm{v}$.
日本渠道叢書

羽塚䜿明编

梁舞研究会 1932 .

As 18 M.340/.H35

A collection of rare books on gagaku (court masic). Subjects covered Include tonallty and rhythm, kumemal, bugaku (court dance music). etc. Detalled explanations are given. Edited and published to Inform the public of the avallablity of valuable muslcal documente. 
MUS ICAL INS TRUMENTS

774 Salbara yakufu 催馬㷊訳譜 (Husical Scoree of Selbara)

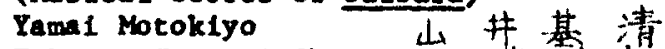
Tokyo: Iranami Shoten 岩波喜店 1966. 302 p.

Salbara, a song of gagaku (court music) genre, which developed from Komagaku (Korean music), 18 scored on mustcal heete and 1 ts vartous facets are explained.

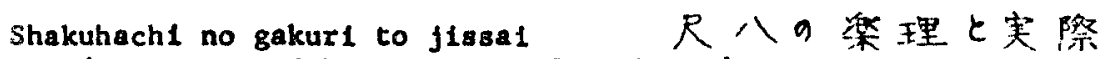
(Theories and Prectices of Shakuhachi) Yoahida Selfú and Maeda Kafu $\bar{u}$ 韋 Tokyo: Kōransha 交茛社 1939. 237 p. 由晴国・前田佳国

The author, who $1 \mathrm{~s}$ a composer and player of Kínko chool shakuhach1 (Japanese flute), presents information considered basic and necessary for the playing of the shakuhachl.

(Historical Backgound of Shakuhach1)

Kurihara Köta 整原広太

Tokyo: Rawase Junsuke 们濑順輔 1925.

263 p. As 1a $\mathrm{KL} .990 / .55 \mathrm{~K} 87$

Delves Into the details of shakuhach1 (Japanese flute) as a mulcal Instrument. Explaing its origin, etymology, transitions and musical role.

Shamisen bunkafu 三味棋文化譜 (Shamisen Mustcal Scores) Bd. by Högakusha Tokyo: $1952+1956$.

$10 \mathrm{v}$.

A collection, In 10 volumes, of muelcal scores for hamieen, Indicating the flrst, second and third strings. With the use of numeralo and codes, gives instructions on finger movemente and techniques. Includes kouta, nagauta, kiyomoto, hauta, zokkyoku, gidari, atc.

Shamisen ongakush1 三味緗音集史

(History of Shamisen Hic)

Tanabe H18ao 田边尚雄

Tokyo： Sōshtaha 制想杜

240 p. 11 lus.

制思社

1963.

As 1a M.140/.T35 
MUSICAL INSTRURENTS

Discusses the or $1 \mathrm{~g}$ in, nomenclature, transmittal processes and present state of shamisen as malcal instrument. Ut111zing old documents and references, the author a 180 takes up various aspect of shamisen mase.

779

Shinran Shōnlp onkyūgek1 Ch1kuzen biwa uta 御泹跤筑前纴琶歌 (Chikuzen Biwa Songs of Higtoric Sites Associated with Priest Shinran) Tachibana Itte1 棌 - 定

Tokyo: Tachibana Chikuzen Biwa Sōke Shuppambu 槆 筑前 琵琶宗家出版部 1923.

3 v.

As 1a ML1015/.B55T32

A collection, in three volumes, of Chikuzen blwa (Japanese lute) songs about historic sites associated with Priest Shinran (1173-1263).

Sōkyoku gakufu Míyagi Michio sakkyokushū 宫城道雄作曲隼

(Mrsical Scores for Koto Muglc Composed by Miyagl Mich1o) Myag1 Michio 客城道雄 Tokyo: Rate1 Ongakukai 家庭音潗会 1955.

$13 \mathrm{v}$.

Mus 1cal acores for use as instructional materials in the sōkyoku department (Roto or Japanese zither mus1c) of the Tokyo Muslc School, present1y, the Tokyo Kational University of PIne Arts and Music. The first edition was published in 1931. Includes representative pleces such as Seoto, Haru-no-umi, Sakura hensökyoku, etc. Compr1sed of 13 volumes.

Sōkyoku kashū: Inutaryū 笔 曲歌集一生田流 (Collection of Roto Songs: Ikuta School) Takahash1 Ich1saku Tokyo: Hakushindo 300 p. 高梽市作 博信堂
1920.

A collection of koto (Japanese zither) songs used for practice by the Ikuta school of koto misic.

Sokyoku no chish1k1 (Knowledge of Koto Mric) Nakn jIma Tosh1 yuk1 Oeaka: Maekawa Göna 1 Ka1sha 369 p.

等曲 9 知誡

中息利之

前川合名会社 1936 . As 1a M142/.K6N34 
MUSICAL INSTRUMENTS

This book presente, for the benefit of persons with koto (Japanese zither) music as a hobby, general information on the subject. It aimo to make them understand koto malic from a popular viewpolnt.

783 Sökyokushü 笋 曲 集

(Collection of Koto Songe) Ed. by Tokyo Ongaku Gakkō Tokyo: Mombushō 丈 部省 1888 .
$1 \mathrm{v}$.
As 1a M142/. K6 J36

A collection of koto (Japanese zither) songs sanctioned by the matc examiner of the Ministry of Education during the Melfl period.

784

Sökyoku ta11 shō
(Koto Mus 1c Collect1on)

Yamada Shōr1 山田松理

Kyoto: Hayashi Yosh1bei. 林芳突衖 1903.

$6 \mathrm{v}$.

A31a M142/.K6Y35

A collection, In $81 x$ volumes, of the music scores of the Yamada school of koto (Japanese zither) masic. Contains pieces of kotokuniuta (oldest form of koto song). The first volume contalna sketches and explanations of the koto as a masical instument.

(Roto Music and Jiuta)

Ed. by Töyö Ongakkal

Tokyo: Ongaku no Tomosha

327 p. illus.

$$
\begin{aligned}
& \text { 束洋音策会編 } \\
& \text { 音楽之友杜 } 1967 \text { 。 }
\end{aligned}
$$

A comprehensive otudy of koto (Japanese zither) music and the accompanylng 11uta. Maln chapters are: "History of Sokyoku and Jluta" by Rikkawa Elshi; "Study of Japanese Koto in Anclent Times" by Hayash1 Ranzo; and "Sōkyoku as Japanese Song Literature" by Hirano Kenjl. A "Jlute and Sökyoku BLbliography" is appended and Ignificant materials are nnotated.

A comprehensive collection of koto (Japanese zither) song texts. with Instrumental notations, of the Yamada school. 
TRADITIONAL AND POPULAR SONGS

Chūsel kayō no kenkyū 中 世歌楞 $\Rightarrow$ 研究, (Study of Japanese Songs of Middle Ages) Agō Toranoshín Tokyo: Kazama Shobö 吾楖富之進 710 p.

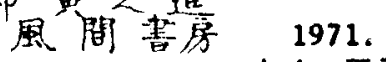

Essays by the author on his study of the origin and special characterlstica of kayo (Japanese songs) of the Midde Ages.

(Collections of Japanese Songs of Middle Ages) Ed. by Asano Renji 清野建=校註 Tokyo: Asahi Shimbunsha 朝日新闃社 322 p.

Collections of representative kayō (Japanese songs) of Middle Ages, namely, Kanglnshū and Chüko zasshōshū. Explanatory comments are given for each and there 1s a listing of significant research materials. Headnotes are included in the texts. Kanginshü was complled in early 16th century and contains enkyoku, denzaku and sarugaku songs, taueuta, funauta, etc. Chüko zasshöshü is a collection of various songs of the Helan period (794-1192), spanning about 400 years. (Annual Chronicle of ChIldren's Songs) Pujita Tamao 滕由圭雄 Tokyo: Mak1 Shoten 259 p. 11108. 牧热店 1965 。

A compilation of songs published in the Mokuyo techo (Thursday Hotebook), a chlldren's song magazine edited by Sató Hachirō, a poet and writer of children's songs. The songe are divided into the four seasons of the year and Impressions are related or commente are made on the varlous songs assoclated with the different seasons. Written with the intent to Instruct young admirers of Satö Hachirō on how to write children's songs. The author himself is a composer of children's congs. 
TRADIT IONAL AND PORULAR SONGS

A collection of 423 Edo kouta with explenatory commentaries. Of the total, 382 songs were either composed during the Edo period or the original pleces, from which these songs vere derlved, emerged during the same pertod. In addition to the 382 songs, 41 paradies which emanated during or after the 1 fl perfod are included.

791

Enka no Me1j1 Talshō sh1

潧歌の6月治大正史

(Meifl and Taisho Hiatory of Enka)

Soeda Tomomichi

264 p. Illus.

添田原口 道

岩波蕃店 1965 .

As1a Ma2851/.J3S65

An entertaining account of the origin and evolution of enka (popular songs sung by street alngers) from about 1887 to 1926 . Gives the social-political and historlcal backgound in explaining the different enka, such as kalryobushi, oppekepé-busht, etc. The author's personal experiences are re lated in the following entry, Enkasht no selkatsu (Life of a Japanese Troubadour).

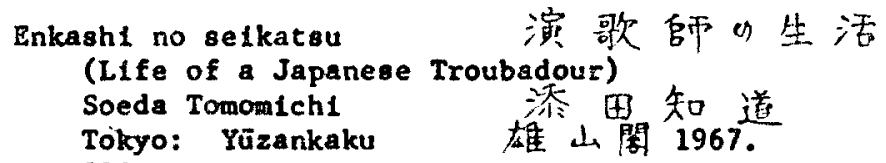
296 p.

Kajlyama

Intermingling his personal experlences as a composer and ofinger of enka (popular songs sung by street singers), the author traces the transitions of enka from Meljl through Taishō periods, and describes the unique and fundamental features of enka. Presents an overall view of enka and 1 ts role in the lives of the people.

附謡曲末百番 (Enkyoku 17 Volumes) Ed. by Yosh1da Tögo and Nomura Hachirō 吉由束俉野村八郎校注 Tokyo: Kokusho Kankōkai 464 p. 国寒刊行会 1912 .

As 1a PL735/.E56

A compllation into one volume of a total of 17 volumes of enkyoku (Japanese songs popular In the late Kamakura to early Muromechl perlods). Included in the 17 volumes are Enkrokusho (5 vols.), Enkyokusho (3 vols.), Krühyakusho (1 v.), etc. Kana readings are given for the texts and headnotes are added. There is an introductory essay explaining enkyoku. This work 1s significant in that 1 t leads the way for subsequent researches on eakyoku. 
TRADITIONAL AND POPULAR SONGS

794 Enkyoku no kenkyū (Study of Enkyoku) Inul Rateumi Tokyo: Ofushe 574 p. illus.

$$
\text { 安日9，研究 }
$$

乾克，己 椄裂社 1972 .

A study of enkyoku (Japanese songs popular In the late Kasakura to early Muromachi perlods). Divided into two parts. Part 1 is titled, "Materiala and Expressions of Enkyoku," and consists of 11 chapters, primarily on enkyoku and 1 ts relations to waka poetry, 11nked verses, storyteli1ng, Buddhism, etc. Part 2 is tithled, "Japanese Songs and Performing Arts Associated with Enkyoku", and presents new materials on kayo (Japanese songs) in the Kanazawa Bunko (Collection) and examines the relationship between performing arts and popular religious beliefs.

795

Enkyoku shüse1

安曲集成

(Enkyoku Collection)

Bd. by Takeisht Akio

Tokyo: Koten Bunko

5 v.

$$
\begin{aligned}
& \text { 武石榇夫䋧 } \\
& \text { 古典文度 } 1972 \text {. } \\
& \text { As1a PL761/.ES5 }
\end{aligned}
$$

A collection, In five volumes, of enkyoku, a type of Japanese cong popular In the Middle Ages. Examples are Enkyokusho, Enkyokushü (1295), Kyūhakushī (1303), etc. Since these are photo reproductions of the Sonkelkakubon written in calligraphy, there are no reprints in block characters. Brief explanations are Included at the end of each volume.

(Collections of Old Japanese Songs)

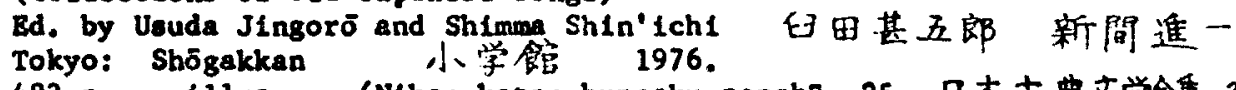

483 p. 11lus. (Mihon koten bungaku zensha, 25 日本古典文学全乗，25) Asia PL753/.N57/v.25

The cextual section of each is arranged in three horizontal columns with headnotes at the top, texts in the center and translations into conversational form at the bottom. Rana readings are given for the texts. Simple explanations and detailed reference liatings precede each of the four collections. 
TRADITIONAL AND POPULAR SONGS

A bound volume of two booklets: Kalcht nagauta hyakuben (Poket-s1ged 100 Nagauta) and Zoku nageute hyekuban)(Poket-a1sed 100 Nagauta, Supplement The first booklet contalns 105 nagauta, printed in block characters with kana readings, and the second, 109 nagauta.

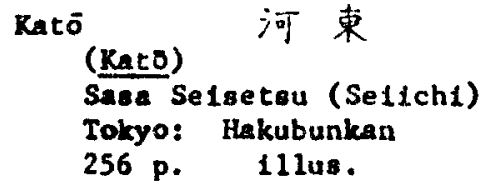

Kato 1s the abbreviated name of katö-bushi föruri. Also called Edo-bushl. In the introductory section relatea the history, transitions, characterisic; etc. of katō. Detalled coments are appended to representative pleces such as Sukeroku, Matsu-no-uchl, etc.

799

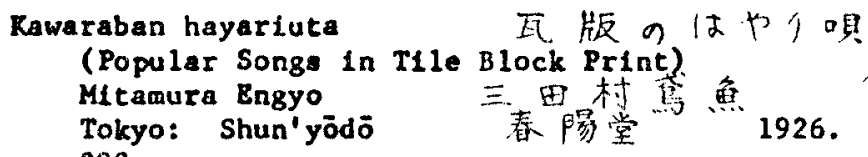

As 1a $11812 / . N 58 K 38$

Takes a look at the hayertuta (popular songs) in the kawaraben (tile block print) published in Edo since the Kael perfod (1848-1854).

Comprised of two volumes. Kayo I 18 a collection of Kikt kayo or songs from Koj1k1 (Records of Anclent Mattera) and Nthon shok1 (Chrontcles of Japan). Rayo II covers songe of the Middle Ages to modern times. Contain. Ryol1n hisho, Kanglnsho, Byatatsu-bught kayo.

801 Kayōshü 歌言集

(Collection of Japanese Songs)

Bd. by Masamune Atsuo 正宗敦夫編

Tokyo: N1hon Koten Zanshū Kanköka1 日本古典全集利行会 1934. 3 v. Asta PL761/. 038

A collection, Ia three volumes, of various types of kapo (Japanese songs), arranged generally in chronologlcal order. There ls an introductory sectlon, with comentaries on kayō, in esch volume.

802 Kente1 shögaku shoka 检定 小紫㕷歌

(Offlcially Approved Gramar School Songs)

Ed. by NBsho Benf1rō

Tokyo: Kyobunsha 纸所 升次郎的 $430 \mathrm{p}$.

京文社 1929.

Asta M1994/.N28X45 
TRADITIONAI AND POPULAR SONGS

A compllation of grammar echool songe sultable as instructional material. during the early wifi period. Categorized by grade levels. Includes both song texts and musical scores.

803

K1nse1 kayōehü 近世歌产集

(Collection of Japanese Songs of Modern $T$ tmes)

Bd. by Sasano Ratash1

Tokyo: Asahi Shimbunaha

筐 轱 堅

朝日新聞杜 1956 .

424 p.

A collection of representative kayō (Japanese songe) of modern times. Includes the following: Ryütatsu-bushl koute shüsel, Sablshtkiza no nagusami, Himekomatsu, Hina no hitofush1, etc.

804
Ki yomoto zenshü
(Riyomoto complete collection)
Ed. by Makaucht Chōj1 and Tawura Nishio
Tokyo: Nihon Onkyoku Zenshū Kankōka1
480 p. (Nihon onkyoku zenshū, 3

中内虫枼二，田村西男编

日本音曲全集刑行会 1928 。

日本音曲全集，3， As ia Mil $340 /$. N55/v. 3

A collection of 104 klyomoto-bushl pieces. Brief sumaries and coments are given at the end of each plece. Glossary of termo 18 given in the headnotes. Pieces are arranged in syllablc order and comonly used titles are alco given. The hlstory of klyomoto-bushl and an index are included at the end.

805 Kokuriteu Gakijō shōmyō kōen (kational Theater Buddhiet Chant Performances)

Rokuritou Cakijō Tokyo: 1970-1974.

5 v.

As 1a PN2924.5/. K3K647

A compllation of the printed program of the various himyo (Buddhist chant) performances held ennually at the llational Theater. The program numbers are explained.

805 Kokyoku zenehū: katō, 1tchū, sonohach1, ogle 古曲全棸 河束。一中。菌八，获江 (Collection of 01d Songe: Kato, Itchū, Sonohachi, Ogie)

Bd. by Bukaucht Choji and Tamara Nishio Tokyo: Nihon Onkyolku Zenshū Rankōka1 1927.

555 p. (Nihon onkyoku zenahū, 11 日本音曲全集，11) 
TRADIT IOMAL AND POPULAR SONGS

A collection of 68 kato-bush1, 60 1tchä-bush1, 10 sonohacht-buehi and 28 ogle-bught songs. Words were taken from varlous type of text8. Bxplanations are given for each song. Arranged by Japrnese oyllabic order.

807

808

809
Rotouta oyobi jiuta zenshü 筆 唄及地唄全果

(Collection of koto Songs and Jiuta)

Bd. by Nakauchi Chōjl and Tamura Nishio

Tokyo: Nihon Onkyoku Zenshü Kankōkai

1927.

$463 \mathrm{p}$

(Nihon onkyoku zenshü, 6

中内蝶二・田村西男稨

日本音曲全集刊行会

日本音曲全集 6)

As 1a ML340/.N55/v.6

A collection of 212 koto (Japanese zither) songs and 316 fluts. Both types of songs are arranged by Japenese syllabic order. A brief explanation 18 given for each song.

Kouta, utazawa, hauta zenshū (Collection of Kouta, Utazawa and Hauta) Ed. by Nakauch1 Chōji and Tamura Nishio Tokyo: Nihon Onkyoku Zenshü Ranköks1 1927. 464 p. (N1hon onkyoku zenshū, 4 小唄・うた沢・端うた金整 中内蝶二・田村西男編 日本音曲全寨形行会

日本音曲全鿖 4) Asia ML340/.N55/v.4

A collection of 197 kouta, 420 utazawa, 170 hauta. Arranged by Japanese syllabic order. Brief headnotes are Included. Conclse h1storles of kouta, utazaws and hauta are given at the end of the work. 柷祭日 儀式用唱歌 (Songs for Holidays and Ceremonles Selected by Ministry of Education)

Tokyo: Dal Nihon Tosho Kabushiki Kashe 大日本团書林武会社 1936. 55 p.

A compilation of song texts and muical ecores of 10 songs oung before World War II on holldays and ceremonial occaslons such as Kigensetsu (Emplre Founding Day) on Pebruery 11. Tenchöectou (Emperor's B1rthday) on April 29 and Yeillsetsu (Emperor Heifi's Birthday Anniversary) on llovember 3. Musical sheets for choruses are included.

10 Nagauta keiko tebikigusa 唇唄けい:手引草 (Guldebook for Nagauta Pract1ces) Machida Hirozō Tokyo: Högaku Kenkyüka1 541 p.

邦臬研究会1923.

A81a M1812/.M33 
TRADITIONAL AND POPULAR SONGS

A guidebook for those who are Interested in and desire to actually learn negauta for those who want to make a theoretic study of it. Part 1 contalns technical instructions on singing and the playing of shamisen and drums. Part 2 is a discusaton of nagauta.

811

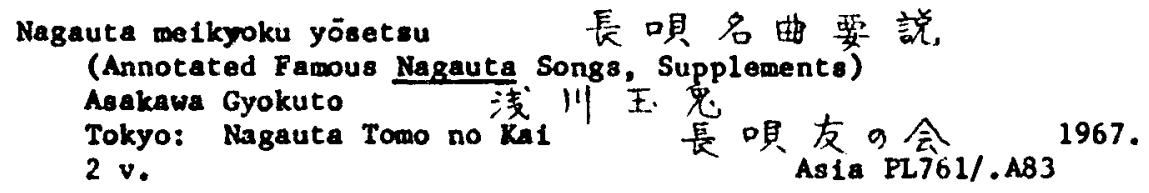

Supplemental work to Nagauta meikyoku yōsetsu, 1950, and Zoku nagauta meikyoku yōsetsu, 1960. Supplement 1 contains 25 songs and Supplement 2 has 23 songs which were not Included in the previous editions. Songe are arranged chronologically. Summary explanations, comments on lyrics and analysis of tunes are given for gach song.

Nagauta zenahū 長唄全集

(Nagauta Collection and Nagauta Collection Supplement) Ed. by Nakauch1 Chöj1 and Tamura Nish10 中内蝶二。田村西男編 Tokyo: N1hon Onkyoku Zenshū Kanköka1 日本音曲全集刑行会 1927 . 2 va. (Nihon onkyoku zenshū, 1, 15 日本音曲全集，1,15) As 1 a ML340/.N55

Collections of Ede nagauta which had been populer during 1927-1928. Total of 135 pleces in Vol. 1 and 166 in Vol. 2. Annotations and headnotes given for each plece. Arranged by Japanese syllabic order. A brief history of nagauta and an Index are appended.

Nanzan shinryi showyo no kenkyu (Study of Buddhist Chant of Manzan Shinryū School) Iwahara Telchin 些原暲信 Kyoto: Yamashiroya Pujfi Shoten 788 p.

A study of the shōmo- (Buddhist chant) of the Nanzan Shinryo school of Shingon sect. Discusses the history, tonal system, practice instructions, etc. of Shinryü shömyó.

Fujita Tamso Tokyo: Alenne Shobo675 p. 111us.
暴田主雄 あか双書房 1971.

As 1. PN1009/.J3F77 
TRADITIONAI. AND POPULAR SONGS

\begin{abstract}
Attempt to trace the hiotory of Japanese children's songs, ut 1lizing the most rellable ource materials avallable. Not a comprehenelve historlcal work since it 18 limited to songs published after the Inftial losue (1918) of the magarine, Aka1 tori (Red Bird).
\end{abstract}

Nihon kayō no kenkyū: toku nl chūsel kinsel o shu to shitaru 日本弱詳の研究—特に中世?近世主とにたる (Study of Japanese Songs: Emphasis on Middle Ages and Pre-modern Times)

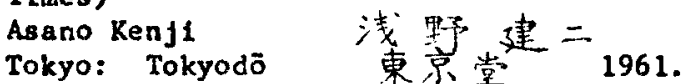
Tokyo: Tokyodo 1961.

Ag ia ML3750/.A8

Collection of the author's essays on kayō (Japanese songs) of the Middle Ages and Pre-modern times. Divided into four sections. The first looks Into the source of kouta of the Middle Ages and deacribes the social environment which gave birth to Muromachl kouta. The second examines the Kanginshü, Ryütatsu koutashü, etc. The third section surveys the songs and accompanyling dances of early modern times while the fourth is primarlly a sudy of the min'yo (folk songs) of Pre-modern times.

Whon kayo no ongaku to kashi no kenkyü 日本歌謤9音隼と歌詞9研究 (Study of Muslc and Lyrlcs of Japanese Songs) Imai Michirō 今े 渞郎 Tokyo: Gakujutsu Bunken Fukyükai 620 p. $111 \mathrm{us.}$

Consists of two parts. Part 1, "Music of Jepanese Songs," is a study of the musical elements, Including rhythm, sale tonality, etc. Part 2, "Lyrics of Japanese Songs," is a study of the rhetorical methods used in the composition of the words.

817 Nihon kayöshi: Me1j1 Ta1shö Shöwa kayōshū 日本歌謡史一明台·大正・昭和歌嬨集 (H1story of Japanese Songs: Collection of Melji, Taishö, Shōwa Songs) Oka Toshio Ir 灯至老 Tokyo: Yayo1 Shobō 弥生書房 1967. 191 p. 11lus. Agia 1812/.04N5

A collection of popular Japanese songs of the Me1jl. Taisho and Showa periods. Samples of songe Included are as follows: Me1j1--Oppekepsbusht (popular song), Kigensetsu (ceremonial cong), Gunkan kosh1nkyoku (nilitary), Momotaro (ch1ldren's song), etc.: Ta1sh8--Kachüaha no uta (modern theater), Söran-busht (folk song), Kanarlya (ch11dren'. song). Suttonton-bushl (popular song), etc.: : Showa-Gion kouta (mobo and moga popular song), Tablgasa dōchü (popular song), Ringo no uta (popular song), Kuroda-bush1 (folk song), etc. Brief articles giving the historical and social background of the times and the traneitions of songe are included at the bottom of each page. 
TRADITIONAL AND POPULAR SONGS

810

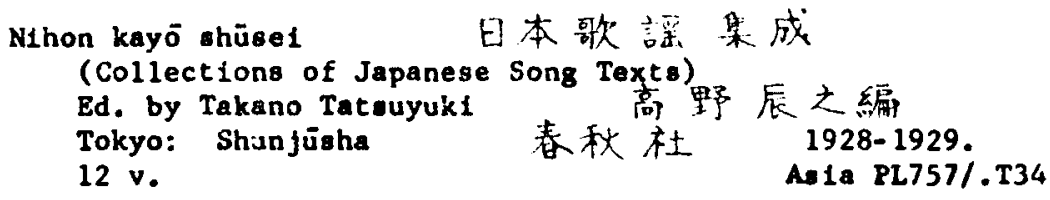

Collections in 12 volumes of texts of important kayó (Japanese songa) of various categories. Arranged in chronological order and reprinted in block characters with kana readings. Explanatory notationa included. Vo1. I covers the ancient parlod with songs in Kojikl (Rocords of Anclent Matters) and Mthon ghok1 (Chronicles of Japan). Vols. 2 and 3 cover the Middle Ages with songs of thelan period such as kagura, salbara, azuma-asob1, rōe1, etc. Vol. 4 overlaps into the early modern period and presents Buddhist chants. Vol. 5 1s early modern and Includes songs of Kamakura and Kuromachi periods. Vols. 6 through 12 cover the modern perlod and contains variety of songs, including popular ghamisen music, nagauta, hauta, itchü-bughi, tokiwazu, tomimoto, kató. shinnai, dodoltsu and folk oongs. Between 1961 and 1964, a supplementary work, Zoku Nihon kayo shüsé 1 was published in five volumes.

819 Nihon koyōshü $\theta$ 本古謡整 (Collection of 01d Japanese Songs) Honda Yosuj1 本 9 安 次 Tokyo: Miralsha 末来社 331 p. L11us.
1962. As La M1812/.H65NS

A collection of 26 pieces of koyó (old Japanese songs) with annotations. Reprinted in block characters. Selected from among the many kayo (Japanese songs), still remaining in the Japanese folk performing arte.

Intended to further the underatanding and appreclation of representative classic Japanese songs. Begins with a general viev of Japanese songs. As representative congs, kagura, saibara, Ryōiln hishö and Kanglnghü are selected. These songe are transcribed into conversational forw and then explatned.

821 Nihon no kayo (Jepanese Songs) Nakentsht Susum and Shime Shin'fchi Tokyo: Kaurede Shobō 河出書痛 257 p. 111us.

中西進，新間僬一 1975. As1a M M 3 $50 /$. N36 
TRADITIONAL AND POPULAR SONGS

A record of the round-table discusaion on K1kl kay or songs from Koilkt (Records of Anclent Matters) and N1hon Bhokl (Chronicles of Japan), Ryōiln hlsho, Kanglnshü and Matsu no ha. Dlocuseion was broadcasted on NKK IV program, "C1tizens University Lectures."

Nhon shomin bunka shiryō shüse1, da1 5-kan, kayo

日本

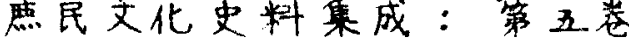
(Collection of Materials on Japanese Popular Culture, Vol, S, Japanese Songs)

Ed. by Geinōsh1 Kenkyūka1 - 芸能史研究会編 Tokyo: San'ich1 Shobō =- 专唐 1974. 947 p. Asia PN2920/.NS/V. 5

A comprehensive, detalled collection of $80 \mathrm{gg}$ materials, heretoforo unpublished or rarely published. Covers a perlod of 500 years, from late Muromach (late 16th century) to end of Edo (1867). Divided into six parts: Taue sōshi-kei kayō. Ryūtatsu-busht kayo, Barly kabuki dance songs, Ofunauta shusei, Folk, children's and popular songs, and lineage and developtent of songs. Reprinted in block characters with kana readings. Explanatory notes in texts. There is an introductory essay for each part giving descriptions, historical background, etc. (From Oppekepe to Folk Takada Mitouo Tokyo: Uno Shoten

238 p. 111us. Asia ML340/.T4507

$$
\text { オッペパーからフォークをで }
$$
Songs) 高田支夫 宇野店 1969 . songs which were popular with the people. Covers the oppekepe, enka and naniwa-bushi of the Melf1 period, Asakusa opera of Taishō perlod, milltary songs of World War II, Jazz music of post-war period and the $\mathrm{OM}$ (comercial) songs, rock mus1c, etc. of the presant day. There is a "Modern Times Music Chronology" at the end of the book.

(Byōjln Hishö)

Salgō Nobutsuna Tokyo: Chlkuma Shobō 237 p.

梁鷹秘抄

西很信筬 筑慗垔房

1976. Ao1a F2787/.R943\$2

A collection of the song texts of lmays (form of kouta) which was popular during the late lleian poriod (1ate 12th century). Ryojin hishō was complled by Emperor Goshirakawa (1127-1192). Song text: in this work were chosen randomly and explalned by the author, Salgo Nobutsuna. A reference rork for general readers rather than a research document. 
TRAUITIONAL AND POPULAR SONGS

825

Ryūkōka Me1j1 Ta1shōshi (Maifi and Taishō History of Byüköka)

Soeda Tomomichi

Tokyo: Shunjǚne

388 p. 11lus.

春秋社 1933 .

A compllation of the lyrics of over 350 ryūkōke (popular songs) of the years between 1867 and 1926. Some of the songs are briefly explained.

826 Saishin Nihon gunkashū

(Collection of Whest Japanese Military Songs)

Ed. by Shükōsha 宗孝社編

Tokyo: 1932.

229 p.

A collection of over 1000 military songs compiled when militarism was on the rise in the country after the Manchurian Incident (1931). Musical scores are not attached.

(Classifled Handbook of Vocal Mus 1c)

\section{Saltö Gesshin}

Tokyo:' Iwanam1 Shoten

489 p. 111us.

$$
\text { 育藤崖波壱店 }
$$

1941.

As 1 a $\mathrm{ML} 340 / .535$

A comprehensive handbook of muslc of the Edo perlod, with emphasis on jorur1. Presents the history of muslc, lyrics, blographical accounts of performers, rapertory of plays, chronological tables and related maters.

Bd. by Yamamoto Yoshiki

Tokyo: Kinensha

158 p.

新日本童謡身

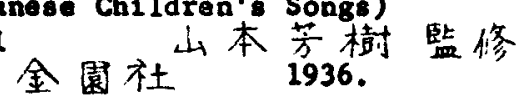

From among new children's oongs, those which can be recommonded to chlldren as being not only wholesome but also, of high artistic and Educational value, were chosen for this collection. Musical scores are Included.

Shōgeku shöka d、学 唱 歌
(Gramon Shool Songa)
Ed. by Mombushó

Tokyo: Kōtō Shiban Gakko Puzoku Ongakłō 1885- 1889.

2 v. (v.1 and 3 )
高等師籍学校附属音楽校 Ae1. M1994/.J3J35 
TRADITIONAL AND POPULAR SONGS

A textbook of gramar school songs edited by the Minletry of Education In early Melji period. Printed on Japenese rice paper with etring binding. Of value as an actual oample of a Malj pexiod textbook.

830

$$
\text { Tendal shömyō talse1 太台声明大成 }
$$

(Compllation of Buddhist Chants of Tandal Sect) Bd. by Yosh1da kōzō and Tak1 Dōn1n 吉田恒三，多紀道忍編 Shiga: Hielzan Enryakuj1

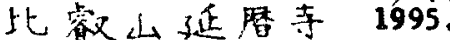
2 v. AB La BQ5060/.J3T34

A compliation, in two volumes, of Tondal sect shomō (Buddhist chant) sald to have been brought from China by prlest Jikaku. The shopyō has been noted on musical sheets and arranged by the types of Buddhist services of both the esoteric and non-esoterlc Buddhist sects.

831 Tokiwazu zenshū 常繁津全集

(Toklwazu Complete Collection)

Ed. by Kakauchi Chöj1 and Tamura N1shio

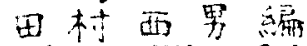

Tokyo: Wihon Onkyoku Zenshü Kankn̄kai

1927.

490 p. (Nihon onkyoku zensha, 8 日本音朋全集, 8)

$$
\text { 中内蝶二 }
$$

日本窗曲全集刑行会

Asta M.340/.N5S/v.8

A collection of 62 pieces from the 120-odd toklwazu foruri pleces which were being performed at the time (1927-1928) of publication of this worte Concise summarles and coments are given at the end of each plece. Headnotes, which serve as a glossary, are included. Tokiwazu pleces are arranged in syllabic order.

Tomimoto oyobi shinnal zenshū 富本及新内全集

(Tomimoto and Shinnei Complete Collection) Ed. by Nakauch 1 Chöji and Tamura Nishio 田村再男丝

Tokyo: N1hon Onkyoku Zenshū Rankökai.

1927.

499 p. (Nihon onkyoku zenshū, 9

中内蝶二

日本音曲全集刑行会

日本音曲全集，9)

A. $1.20340 \%$. $1555 / v .9$

A collection of 35 tomlmoto-bush1 förurl and 45 shinnat-bught jörur pieces which were most popular at the time (1927) of publication of this work. Brief synopsis and commente are given at the end of the pleces. Glossaries of terms are given in the headnotes of the scripts. At the end of the book, the histories of tomimoto-bushl and shinnal-bushi are presented. 
TRADITIONAL AND POPULAR SONGS

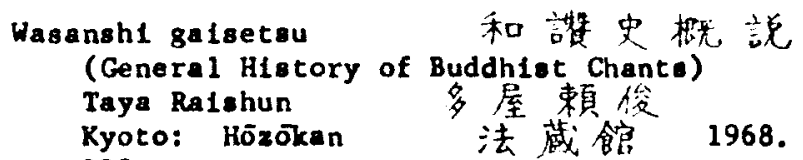

As 1a BL1477.3/.T38

An outline history of the wasan (Japanese version of Buddhist chant) whlch developed from shomy (Buddhlst chant) and became truly Japanese In etyle under the influence of native songs such as gagaku (court mus 1c).

1901.

As 18 PL738/. J6N33

A collection of zokkyoku (popular songs) such as nagauta, kouta, hauta, kiyomoto, tokiwazu, etc. Presents a comprehensive view of popular types of Japanese songs and music. $500 \mathrm{p}$. Asla ML340/.N55/v.7

A compllation of 253 representative zokkyoku (popular songs) from Bunroku period (1592-1595) to Tatshō period (1912-1926). Explanations, as well as headnotes, are 8 iven for each piece. The "History of Zokkyoku" from pre-Bdo period to Taishó period is presented simply and concretely at the end of the work.

836 Zoku negauta melkyoku yösetsu

(Annotated Famous Nagauta Songs, Supplement)
Asaknwa Gyokuto

Sumoto: Magauta Tomo no Ral 414 p.

㬎壳長唄名曲要説

辰呾灰9会

As 1a $\mathrm{M1812/.A83}$

A chronological compllation of about 50 nagauta pleces, which are not too popular and which were left out the 1956 edition of Nagauta meikyoku yosetsu. Lyrics, composer, apecial features, rhythm, performance tim, etc. are glven for each sons. 
TRADITIONAL AND POPULAR SONGS

833 Zoku Nihon kayöken hi 糸志日本歌言圈史 (Comprehensive History of Japanese Songs, Supplement) Sh1de Engi Tokyo: Shibundō 482 p.

1968.

A comprehensive historical survey of Japanese songe from Kikl karo or songe from Kojlk1 (Records of Ancient Hetters) and Nihon ohok1 (Chronicles of Japan) to songs of modern times. A supplemental work to the author's Nihon kayojken sh1.

838 Zoku Nihon kayō shūsel 䌼日本歌㦈集成。 (Collections of Japanese Song Texts, Supplement) Ed. by Shida Eng1 Tokyo: Tokyodö 4 v. $(v .2-5)$

As 10. PL757/.T341

Revised, supplementary edition (1961-1964), In flve volumas, of Mihon kayo shüse1 edited (1928-1929) by Takano Tatsuyuk1. Tho latter work Is listed above. Intended to expand and update the previous work. Vol. 2 covers the Middle Ages, Vols. 3 and 4, Barly Modern Age and Vol. 5, Modern Age. Vol. 5 contains songs of recent times (Hafjl, Taishō and early Shöva periods) and includes a wide coverage of gramax school songs, milttary songe, student dormitory songs, hyrans, etc. Explanatory notes for the texts and an introductory esay for the varlous categorles of songs are presented in each volume. 
POPULAR ENTERTAINMENTS

843

$$
\begin{aligned}
& \text { Enshō zenshū } \\
& \text { (Enshō Collection) } \\
& \text { San'yūte1 Enshō } \\
& \text { Tokyo: Selabs } \\
& 5 \text { v. illus. }
\end{aligned}
$$$$
\text { 円生全集 }
$$

Records verbatim the classic, traditional rakugo (comic stories) narrated by San'yütel Ensho VI (1901-)). Text shows use of bodily gestures, examples of which are given in photo illustrations of Ensho's stage acts.

844
三觜蛙序

As 1a PL838/.A65/1967
青蛙度生范伸編
Hayashlya Shōzo zuldan

(Random Talks of Shōzo

Ed. by Asoo Yoshinobu

$$
\text { Tokyo: Selabö }
$$

331 p.

111us.

Records the informal conversations held by the author with Hayashiya Shōzō VIII (1895-)). Conversations include art talks, recollections, etc. of Hayashiya Shöō.

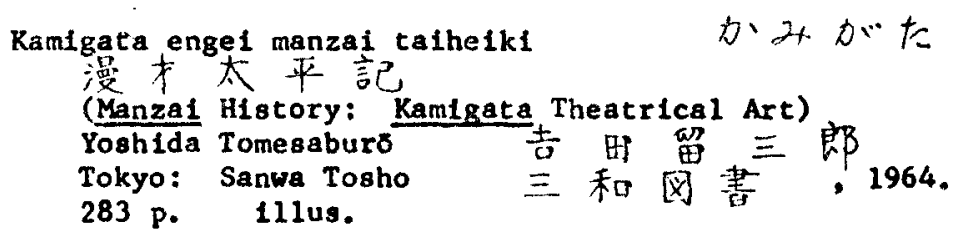

林家正蔵隨談

Hayashiya)

As ia PN4355/.J3Ä86

Documents the origin and historical evolution of manzal (comic dialogue). Examines the Ramigata (Osaka) theatrical art of making people laugh.

上丈はなし第一集一必九集

(Kamigata Story)

Ed. by Shöfukutei Shökaku 功代目笑楅亭松鹤編

Tokyo: San'ich1 Shobó $\equiv$ - 書 $\}^{\prime}, 1971$.1972.

2 v.

Asta PL776/.R35

Reprint of the periodical, Kamigeta hanash1 (Kyoto-Osaka Story), published in Osaka as the organ of Rakugosō. Vol. 1 contains Issues 1 (dated March 1936) to 26, and Vol. 2, 1seves 27 to 49 (October 1940). Edited by rakugoka (com1c storyteller), Shökaku Shōfukute1 V. 
POPULAR ENTERTAINMENTS

847

Ramigata hanashl kö t方落語考

(Thoughts on Comic Storytelling In Kyoto-0saka Area)

U1 Mushū Solabo: 宇抹算愁

512 p.

Asta PN4355 $\widetilde{.}$ Ju35

Explalns the origln, developments and distingulshing features of rakugo (comlc storytelling) in Kamigata (Kyoto-Osaka area). Comments on the rise and fall of rakugo in Kamlgata and pays particular attention to causes which led to loss in its popularity.

848

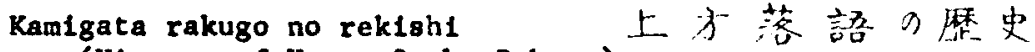
(History of Kyoto-Osaka Rakugo)

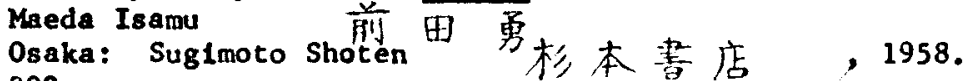
292 p.

Traces the historical evolution of rakugo (comic storytelling) In Kamlgata (Kyoto-Osaka) and analyzes the etymology of the word, rakugo. Lists the titles and och1 (punch line) of Kamigata rakugo and proceeds to classify and explain the humor of each.

$$
\begin{aligned}
& \text { Kamish1ba1 Shōwa shi 紙 芒居 昭和史 } \\
& \text { (Shōwa History of Kamish1bai) } \\
& \text { Kata Köj1 加太 } \\
& \text { Tokyo: Tachikaze Shobo } \text { II 国書房 } \\
& 283 \text { p. I11us. }
\end{aligned}
$$

Chronicles events and personalities assoclated with kamishibal (plcture-card show), which started to become popular during the Showa wars of 19308 and disappeared from the local scene in the 1960s with post-war modernization.

Ratsura Bunraku no beka1 (World of Bunraku Ratsura)

Yamamoto Masuhiro

Tokyo: Gelfüsha

230 p. 111 us.

芸本益博

桂文楽の世界

A commentary on the sk111 and artistry in the stage performance of rakugoka (comlc storyteller), Katsura Bunraku (1892-1971). 
POPULAR ENTERTAINMENTS

851 Rōdan gohyakunen
(500 Years of Storyteli1ng)
Sano Takash1 談五百年
Tokyo: Tsuru Shobo 佐野孝
329 p.

Relates the nature and development of atorytelling. Records the history of how storyteling began and how the stories were transcribed into reading materials.

Outlines the historlcal background and transformation in the performances of kbdan (storytell1ng) and rakugo (comlc storytelling) from the Edo period through Meiji-Tatsho eras. (Past and Present Storles of Ködan and Rakugo)

Sekine Mokuan

Tokyo: Yūzankaku 哭 㮛 默 庵

$356 \mathrm{p}$.

, 1924.

As 1e $\mathrm{PL} 746 / .544$

Narrates chronologically, the development of ködan (storytelling) and rakugo (comlc storyteliing). Starts with Keichö (1596-1615) and Genna (1615-1624) periods, when ködan and rakugo started, and ends around 1907. Narration is interopersed with many eplsodes to entertain and enlighten readers.

Koten rakugo talkei 古禹落詻大系 (Outline of Classic Rakugo) Tokyo: San'ich1 Shobō $\equiv$ - 書房 $=$ - 書房 Asia PL776/.1968 $8 \mathrm{v}$.

A comprehensive collection of classic rakugo (comlc stories) complied with the Intent of converting a narrative art into a ilterary art. Classic rakugo reveals the langurge, custong and human feelings of the common people.

KojIma Te1ji 小丞 昼 Tokyo: $220 \mathrm{p}$.
脢日新閶社, 1965. As 1a PN4355/. J3K62 
POPULAR EMTERTAINMRNTS

Traces the changes in the form and content of the manzal (comic dialogue) over the years. Explains the present manzal technique with examples of the dialogue exchanged between two performers.

856 Nihon bungaku to rakugo $\theta$ 本丈学と落吾 (Japanese Literature and Rakugo) Ok1t8u Kaname 积 津 要 Tokyo: Ōfüsha 婪根杜，1965. 182 p. As 1a PL740\%.64

Surveys, systematically and chronologically, the relat lonships between Japanese 11 terature and the narrative art of rakugo (comic storytelling).

Nihonjin no waral to rakugo (Japanese laughter and Rakugo) Fuse Shöich1 1970. 291 p. As 1a PL746/.F87

Analyzes the contents of classic rakugo (comlc story) to learn what makes people laugh. Traces historlcal development to determine how these stories were composed. Explains why this form of popular entertalnment appealed to modern-day Japanese of Tokyo-0saka-Kyoto cities.

858 Nihon rōkyokushi 日本浪曲史 (H1story of Japanese Rökyoku) Masaoka Iruru If 阊 容 Tokyo: Nambokusha 南北社, 1968. 432 p. 11lus. As 1a PN2975/.M3/1968

Delineates the historical evolution of rokyoku (storyteling chant) from the late Edo perlod up to the mid-1960s. Explains how to appreciate rōkyoku and points out its distinguishing features as well as shortcomings as an art form.

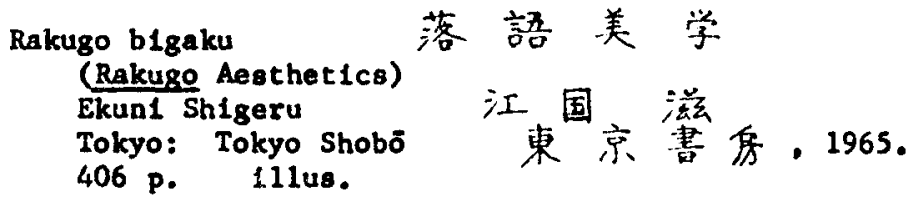


POPULAR ENTERTAINMENTS

Invitation to the world of rakugo (comic storytelling) by the author who is a great fan. Dtscusses its philosophical aspects, visita and describes various Tokyo stes which are mentioned in rakugo and reveals anecdotes of famous rakugoka (comic storytellers).

860

Rakugo jiten
(Rakugo Handbook)

Imamura Nobuo

Tokyo: Selabō

349 p.

落語事覀

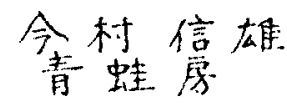

, 1957.

As la Ref. PL746/.R35

Notates and interprets the synopses of about 500 well-known rakugo (comic stories) from the Edo period to the present. Explains the humor of the sage (punch line). Gives, at the beginning, a brief historical account of rakugo, genealogy of the various schools and explanations of the sage. A directory is appended, listing personal historles, performance styles and addresses of 83 present zakugoka (comic storytellers).

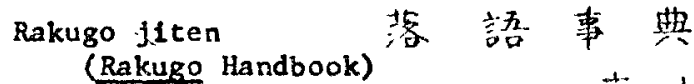

Ed. by Toda1 Rakugoka1

Tokyo: Seiabō 青蛙房 , 1969.

470 p.

As ia Ref. PL746/.T62

A compllation of 870 rakugo (comic stories) in summarized form and with comentaries. Arranged in syllabic order. Compiled by ex-members of the Tokyo University Rakugo Research Society with the Intent of revising Nobuo Imamura's Rakugo fiten (Rakugo Handbook), published in 1957 by Selabo.

Rakugoka no setkatsu

落語家の生活

(Life of a Rakugoka)

Uchiyama Sōjūrö

Tokyo: Yuzankaku

雄山俻留。十郎

254 p.

Rajiyama

Serves as an orlentation guide to rakugo (comle storyteling). Describes its origin and development, present state of the art, Including popular rakugoka (comlc storytellers), and its types and special features.

ion of Rakugo)

Ando Tsuruo

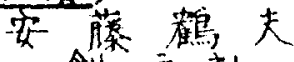
Tokyo: Sōgensha 365 p. 
POPULAR ENTERTAINRENTS

\begin{abstract}
Relates 14 representative rakugo (comic stories) which the author 11kes. Most of the selected rakugo were narrated by the rakugoka (comic storyteller), Katsura Bunraku (1892-1971), and recorded by the author. Contains comments on enjoyment of outstanding rakugoka, value of expertise in stage presentation, etc.
\end{abstract} Rakugo keizu
(Rakugo Genealogy) 落語系四 Uemura Shüich1rō Tokyo: Me1cho Rankōka1 名著刑行会, 1965. 226 p. 111us. Asia Ref. PN4355/.J3U33

Records the genealogies of rakugoka (comle storytellers). Includes yose (variety show).b1liboards used during the Me1j1Tałshō-Shōwa eras.

A compilation of 420 rakugo (comic stories) with original source citations, explanations and references. Traces the evolution of comic folktales into well-known rakugo of traditional vintage.

Rakugo no kenkyū

(Rakugo Research)

Watanabe Kin

落語9石开究

293 p.

駸堂書店. 1943 . Rajiyama

Alms to provide common, orthodox knowledge concerning rakugo (comlc storytelling). Explains its history, types of ochl (punch lines) and characteristics of Osaka rakugo. Discusses the works and contributions of comic book writer, Ryütel R1 jo (? - 1841).

Rakugo no seka1 (Rakugo Wor 1d)

Imamura Nobuo

Tokyo: Selabō

237 p.

111us.

落語の世界

今村信雄

青蛙序。1956。 
POPULAR ENTERTAINOENTS

Relates eplsodes of the rakugo (comic otory) world and anocdotes of rakugoka (comic storytellers). A rakugo dictionary, contsining terminology, argot, code words, slang, etc., la appended.

868

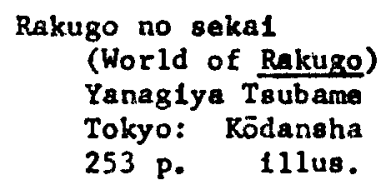

As 1a PN4355/.J3Y35

Introduces beginners to the rakugo (comlc storytelling) world. Explains the steps involved in becoming a full-fledged rakugoka (comic storyteller), the trials and tribulations endured, the delights and satisfactions experienced, etc. A rakugo glossary is appended.

落語倫理学 池束京畫房一。1971. As 1a PL746/.164

Dlocusses and analyzes 45 rakugo (comic storles). For each rakugo, explains the meaning of the title, gives a synopsis of the story and then interprets its comical aspects.

Rakugo sambakudal: rakugo no kosek shlrabe

(Rakugo 300 Titles: Rakugo Background Check)

Mutó Sadao

Tokyo: Tokyodö

Presents synopses of rakugo (comic stories) and explains the humor and origin of each. Notes that many of the gage (punch Iines), makura (1ntroductory remarks) and kusugur1 (bumorous b1ts) used In rakugo orlglnated as Edo kobanaght (jokes). Tries to analyze the relations between the narrative art of rakugo and 11terary form of Edo Jokes.

871 Rakugo yuhodō 落語遊步道

(Rakugo Promenade) Yano Selichi Tokyo: Kyödō KLkaku 213 p. 111us.

$$
\text { 矢野誠 一 坫同企画 }
$$

, 1967.

Kajlyama 
POPULAR ENTERTAINMENTS

Visits the sites which have become famous in rakugo (comic otorytelling) and describes them with ald of photo illustrations. Introduces beginners to the rakugo world.

Rakugo senshū 落語避集

(Rakugo Anthology)

Ed. by Bakushō Yotarō and Imamura Nobuo 爆笑与太郎。 今村信雄編

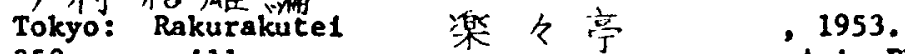

358 p. 111u8. As1a PL746/.I53

Selected works of rakugo (comic storles) with cartoon 1llustrations.

873

Rakugo zenshū 落語全霖

(Rakugo Complete Works)

Tokyo: Da1 Nihon Yübenkal Kodansha 1929.

3 v. $111 \mathrm{us}$.

大日本雄并会講談社

Asia PN6222/.J3R34

A comprehensive collection of rakugo (comlc storles), including jokes, lllustrated with cartoon sketches.

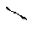

874

San' yūtel Enchō

Nagal Hiroo

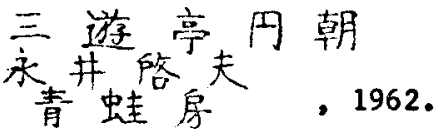

Tokyo: Selabō

299 p. 11lus.

As 1a PN4355/.J32S372

A blography of San'yütel Enchō (1839-1900) who achleved fame in the theatrical circles of Melji perlod. Complled from fragmentary records left by Enchō and recollectlons of those who had been affillated with him. Includes varlous types of stories, Including rakugo (comic otories), narrated by Enchō.

875

Sh1nshō kuruwabanash 1

(Sh1nshō' Rakugo About Licensed Quarters) Rokonte1 ShInshō

Tokyo: Tachikaze Shobō 立風書房, 1970.

388 p. Kajigama

A collection of rakugo (comic stories) about licenoed quarters from the repertory of Kokontel Shinsho (1890 - ).

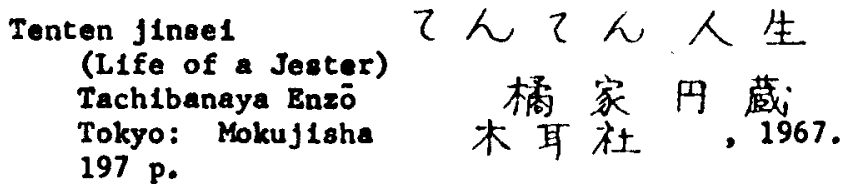


POPULAR ENTERTAIEAEATS

881

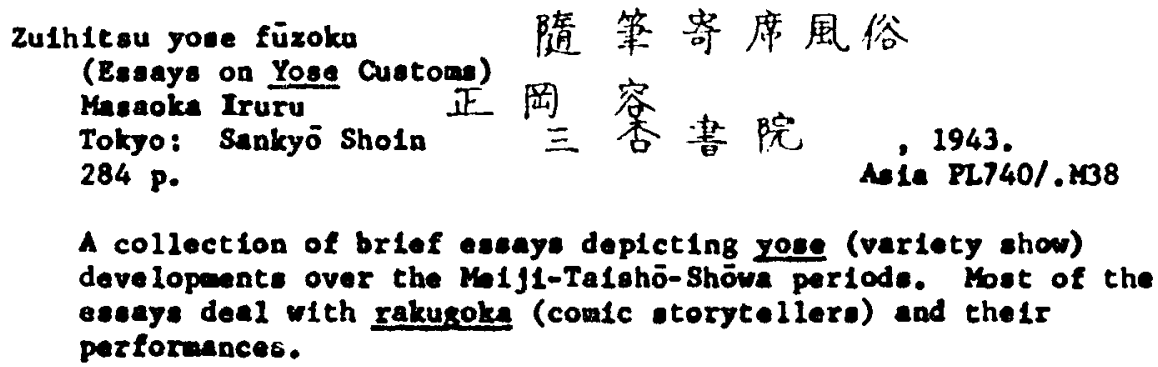



Yanag1 ELj1ro

Tokyo: Selabö 283 p. $111 \mathrm{us}$.

桧番附，新派㓺談 Sheets and Talks on ShImpa) 柳永二郎 青蛙愿
, 1966.

As 1a PN2924/Y.28

Discusses Shimps (modern drama) plays and prominent actors of the recent past. Contalns 11 lustrated progran sheets, photos of stage scenes and actors, etc. Gives brief chronological account of the modern drama movenent. Serves as a gulde to Shlmpe and was written by an actor.

Engek1 nempyo 演虔年表

(Chronicle of Theatrical Performances)

Fujita Hirosh1 缕时洋

Tokyo: Geinō

318 p. 111us. 芸能, 1969.

A chronicle of comerclal and modern theater performances staged In Tokyo and Nagoya-Kyoto-O3aka areas between December 1964 and December 1968. Records the names of plays and theaters, dates, production staffs and ectors and roles. Includes brief comments on and newspaper reviews of performances.

Engek1 ronshū 演虔諭霜

(Articles on Theatrical Artg)

Osana 1 Raoru

Tokyo: Nittödö

$435 \mathrm{p}$.

小允付薰，1916。

As 1a PN2924/.883E54

A miscellany consisting of the following: theatrical play reviews; a ims and plans for the Jiyu Gek1jo (Free Theater); comments on play structures, stage settings and actors' performances; and the author's hopes and ideas to reform the modern theater.

(Autoblography of Theatrical Arts)

Nakamura Gen'emon 申村梘右街阴

Tokyo: Miralsha 末来社, 1976.

348 p. 111us.

As 1a PN2061/.N26

Presents the personal vlews of Nakamura Gan'emon, who started out as a kabukj actor and later became a leader and prominent actor in modern drama at the Zenshinza theater. Contains his comments on theatrical arts, development of modern drama and movie acting skilis. 
MODERN THEATER

$$
\text { 岸田国土杜 }
$$

- 1950.

A. Ia PN2924/.K58

A comprehensive collection of writings on modern drama by Kunio Kishida (1890-1954), who contributed to the development of modern theater. Contains the author's comments, Impressions, thoughts, etc. published in magazines and newspapers. These articles were classified and arranged systematically, with supplementary notes by the author.

(Treatise on Presont-day Modern Theater) Oyama Isao 大 4 In

Tokyo: NampöSholn 㳦方㶳院，1943. 439 p.

A compllation of 40 articles on researches, comentaries, impressions, etc. which were published in newspapers and magazines over a period of approximately 10 years from 1933. The author was formerly editor of the magazine, Nihon engekt (Japanese Theatrical Arts), which was published during World War II.

(Free Theatre)

Osanal Kaoru and Ich1kawa Sadanj1 市川左且次

Tokyo: Ikubundō 有文堂 275 p.

$$
\text { 小山内薰。 }
$$

, 1912. As 1a PN 2924/.083J58

Founders of the J1yū Gek11ō ("Pree Theater Group") personally record their own activities concerning the theater. Th1s book 1s valuable as a basic source material for the study of historical development of modern theater and $a s$ a document to understand the oltuation of the theatrical world at that time.

Kuda1me Danjürō to watakush1

(Danjürō IX and I)

Ichtkara Suisen

Tokyo: Rikugel Shobō

225 p. 11148 .

九代目団十郎と私<smiles>C#CC(C)(C)C#CC(C)(C)C</smiles>

, 1966.

As 1a PN2928/. I28

The author, who 18 the grandchild of Ichikaws Danjoro IX (1838-1903), relates her life experlences from childhood to adulthood as Shlmpa (modern drama) actress. Though Danjüró IX died before her birth, he was her moral support and Inspiration in her acting career. 
MODERN THEATER

Meij1 Talshō shingekiohi sh1ryō 明治大正新韧史资料 (H1storical Materials on Modern Theater During Meij1-Taishö Eras)

Tanaka Eizō 由中栄三

Tokyo: Engek1 Shuppansha 演酟出版社, 1964。

256 p. 11lus. Asla Ref. PH2924/.T32

A history of the rise and fall of modern theater movement. Highly valuable as source materlals, with 176 stage photos and chronological charts of theatrical performances.

891

Mo hitotsu no shingekl shi

(Another History of Modern Drama)

Senda Roreya 千 $⿴$ 是计

Tokyo: Chikuma Shobō 筑摩書房 1975.

190 p. 11 lus.

An autobiographical narrative of the author's $11 \mathrm{fe}$, focusing on his stage activities prior to World War II. Covers the period from 1904, when he was born, to 1945.

Records, in detall, all of the modern theater activities in the Nagoya district from 1921 until the post-World War II perlod. Constitutes a local history of theatrical arts. (H1story of Modern Theater in Japan)
Akiba Taró 秋庭太郎
Tokyo: Rfsosha

586 p. (V. 1)

Consists of two volumes and comprises research on the new theatrical art, which otarted between 1877 and 1886, as a movement to reform kabuk1. 
MODERN THEATER

Traces the rise and fall of the modern drams movement, starting with the formation of the Bungel Kyöka1 (L1terature and Art Soctety) by Tsubouch1 Shöyō and the Jiyū Gek1jō (Free Theater) by Ichikawa Sadanfi and Osanal Kaoru. Reminisces over the fervor shown and poverty endured by the many persons, who were dedicated to keeping the movement alive and current, from its inception to the present day.

N1hon shingek1 shōsh1

日本新虔小史

(Short History of Modern Drama in Japan)

Ibarak1 Tadashi 药木塞

Tokyo: Miraisha 末 来杜

$176 \mathrm{p}$.

未来社，1966。

As1a PN2924/. I33

A brief historlcal account of the modern drama whlch began toward the end of the Meljl era. A chronologdcal sumary of the movement is appended. Useful as a beginner's guide.

896

Ningen Tsubouch 1 Shōyō: kindal gekldan sokumensh1

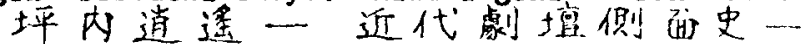

(The Human Shoyō Tsubouchi: Historical Sidelights of Modern Drama)

Kawatake Shigetoshi

Tokyo: Shinjusha 河竹繁 俊

396 p. 1llus. 新樹社。，1959。

A collection of 42 essays on Tsubouchi Shöyö penned by his disciple. Essays are based on the author's memos and personal records kept over the years.

897
Onnagata geidan 女形芝談
(Art Talks of a Female Impersonator)
Kawarazaki Runitarō
Tokyo: Miralsha
河原崎国太郎
, 1976 .

298 p. 111us.

来社

The author, who 18 an onnagata (female 1mpersonator) actor of Zenahlnza theater, recollects his tralning to become an onnagata and relates varlous eplsodes assoclated with his performances In traditional and neo-kabuki plays. Sumarizes, In short essays, random thoughts on hls particlpation in the modern drams movement.

Osana1 Raoru
Kubo Sakae 小公保菜
Tokyo: Bunge1 Shunjüsha
251 p.


A critical blography of Osanal Kaoru. To verify and support his account, the author used as references, 30 documents by 30 authors, Including Osanai's autobiography, and recorded chronologically his words and actions.

形成と展望

(Formation and 0 atlook of Pogt-War Theatrical Arts)

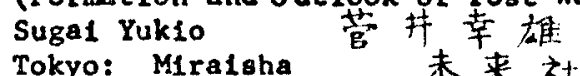

Tokyo: Miralsha 未来社，1967。

2 v. 111us.

戦聁演㓺の

Criticizes the tendencies of modern drame clrcles to write plays which are confined to personal experlences or to take the easy route of introducing forelgn plays. Claims these tendencles must be overcome to achfeve true advancement. Advocates that efforts be made to attain realion in theatrical expresstons by grasping the underlying truths of social development In Japan.

900

Shibal nyūmon 芝居入門

(An. Introduction to Plays)

Osana1 Kaoru and Kitamura Kihachi 北村 喜八

Tokyo: Iwanaml Shoten

262 p. 111us.

$$
\text { 岩波書店，1939. }
$$$$
\text { 小山内蔒 }
$$

$A$ basic and enlightening handbook written after the rise of Japan's shingeki movement.

Sh Lmamura Höget su

Ozak1 Hirotsugu

Tokyo: Miralsha

197 p. 111us.

日本近代㓺 $\sigma$ 䧻始者た5 I)

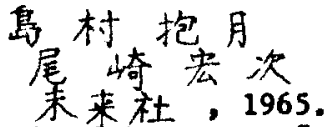

尾崎去，1965 Nihon kindaigeki' no söshlshatach1, 1

Portrays the role and contributione of Shimamura Högetsu in the development of modern drama in Japan, by Interpreting his writings. Constitutes Vol. 1 of the author's serles of three books on Pounders of Japanese Modern Drama.

Shimamura Hōgetsu: h1to oyobl bungakusha to shite

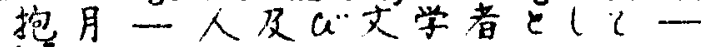
(Hogetsu Shimamura: As Man and Literary Man) Kawazoe Kunimoto III 副国基 Tokyo: Waseda Dalgaku Shuppambu 早稻时大学出版部 1953 206 P. 
MODERN THEATER

Analyzes Shimamura Hōgetsu as a human befing and as a man of letters. Author considers this monograph as an introductory text to studies on the talented and complex Hogetsu.

903

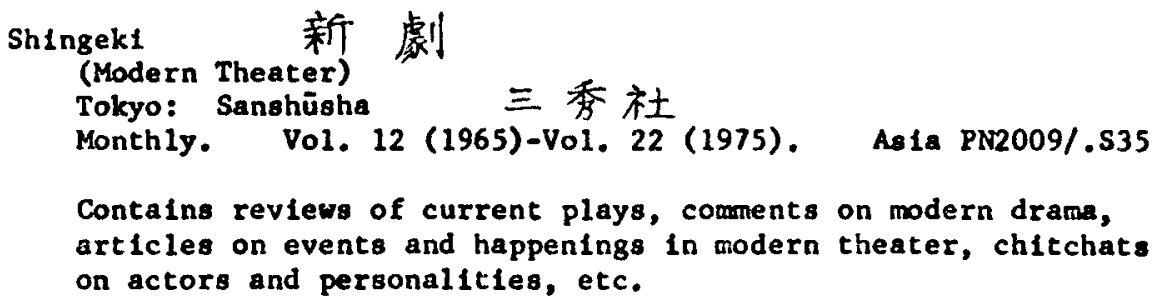

Sh1ngek1 hyōbank1 新㓺言平判記 (Comnentaries on the Modern Theater) Hanada Riyoteru and Tak
武 昭夫 対談
Tokyo: Reisò Shobo 309 p. 111us.

$$
\text { 花田清糔。 }
$$

到草書房，1961。 Asia PN2924/.H35

Commentaries on the modern theater, published intermittently in the magazine, Te-a-to-ro (Theater), between November 1959 and March 1961. (Chronicle of Modern Theater, Pre- and Post-War Editions) Rurabayashi Selichiro Tokyo: Hakusulsha 2 v. (Vo1. 1 and 3) 林誠一郎 白我社 , 1966. As 1a PN2924/. K78

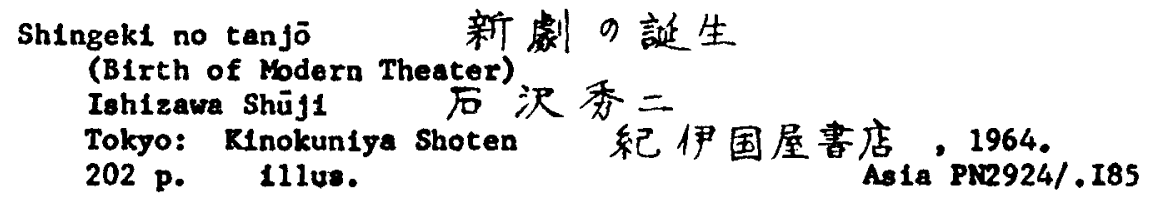

A conclse introduction to the history of modern theater. Attempts to clarify the historic role played by the modern theater. 
MODERN THEATER

907 Shingek1, tanosh1 kanash1 新㓺. 愉 $し$ 哀 $L$ (Modern Theater, Happiness and Sadness) Uno Jükich1 宇野重吉 Tokyo: Rironsha 理阵社, 1969. 390 p.

As 1. PN2928/.USA3

A collection of essays, written in an autoblographical atyle, by Uno Jükichi. Covers briefly hlo childhood, marriage and family, and war-time years. Harrates, In greater detall, his entrance in the modern theater and performances as an actor. Includes random comments on his acqueintances in the theatrical world.

1956. As1a PN2115/.188

Memoirs of the author (Shlshl Bunroku), recollecting his stay in France and study of the French theater, his participation in the madern theater movement upon his return to Japan, and his services as a consultant in establishing the Bungakuza theater.

(Dawn of Modern Theater Mbvement)

Kawatake Shigetosh 1

Tokyo: Yūzankaku

420 p.

1947. Ale P12924/.238

Gives an overall view of the modern theater movement and documents the history of the early period of the movement, wth Tsubouchi Shoys as the central figure. The firet section gives a summary account of the significant events in modern theater history, from the early days of Bungel Byblal (Iiterature and Art Soclety) and Jiyū Gek1tō (Free Theater) untli immediately after the Pacific War. The second section relates the activities of Shōō, in the theatrical reform, from materialo in his diary and other records. (50th Year of Shinkokugek1) Ed. by Shinkokugekidan Tokyo: Nakabayash1 Shuppan 322 p. 111us.

新国㓺五十年 新国劇田編 中林出版 1967 . 
MODERN THEATER

A publication, commemorating the 50th anniversary (1967), of the Shinkokugek1 theater. Records 1 ts history and development in a series of photo illustrations of scenes from performances staged by the theater group.

Taldan N1hon shingeklshi 対談 日本新㓺史

(Interviews on History of Japanese Modern Theater)

Rd. by Tolta Yasuj1 F板 康二編

Tokyo: Selabō 青蛙房, 1961 .

287 p.

As 1a PN2924/.T68

Interviews 20 leading theatrical critics and figures to record the history of modern theater in Japan. First published in 18 Installments in the magazine, Shingek1 (Modern Theater), between September 1958 and June 1960.

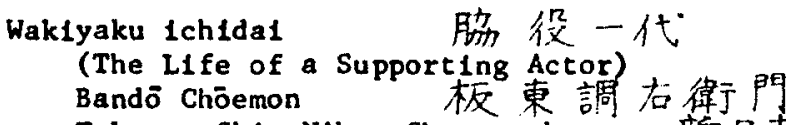

Tokyo: Shin Nihon Shuppansha 新日本出版社, 1977.
222 p. $111 u s$.
As 1a PN2928/.B29A38

An autoblography of an actor, who spent this lifetime as a supporting actor, first in kabuki plays and then in Zenshinza theater. Narration 18 interspersed with art talks of a long acting career.

Warera no gekifō

(Our Theater)

Klahida Kunio

Tokyo: ShInchōsha

324 p.
我等の劇場

岸田国士

新潮社，1916.

As 1a PN2924/. X58W37

The author's first collection of theatrical art coments, based on his knowledge of modern plays of France. Useful as reference source for modern theater history.

Wataghi no engeki hakusho 私9演虔白婁

(My Theatrical White Paper)

Fukuda Touneari

Tokyo: Shinchōeha

262 p. 111us.

楅田恒存 新潮社

- 1958. As 1a PN1623/.F84

A collection of reviews and criticisms of modern theatrical plays performed, and seen by the author, between April 1957 and May 1959. Included are ShImpa, Bhlngek1, Shinkokugek1, Zenshinza, and taishūgek1 plays. 
MODERN THEATER

915

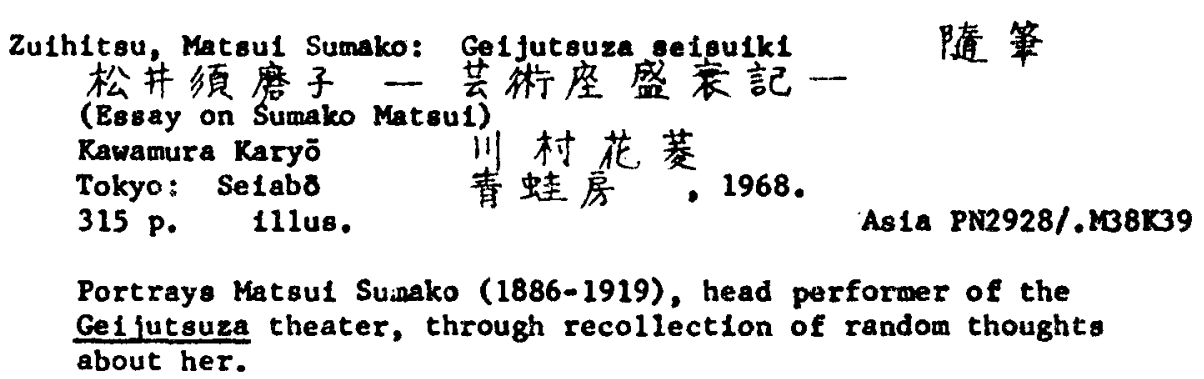
about her.

\section{隨筆}


FOLK PERFORMING ARTS - GENERAL

916

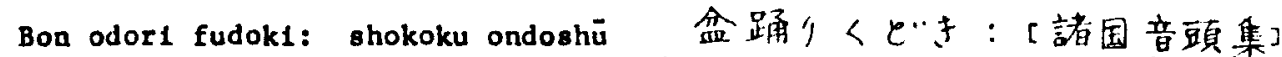
(Analytical Account of Bon Dances) Collection of Local Songs)

Narita Mamoru 成召守

Tokyo: Ōfüsha 桇相杜 1975.

239 p.

As1a PL748/. N35

An analytical description of bon dances, relating the origin, development in various parts of Japan, composition of song texts, etc. Emphasis is placed on the syllabic pattern and types of songs, such as ausplclous, Instructional, love-sulcide, legendary, revenge, etc. There $1 \mathrm{~s}$ a chart at the end identifying the names of the songs, areas in Japan where they are sung, types of songs and explanatory footnotes.

917 Bon odor1 zakkō 盆踊杂隹䏝

(Random Collection of Bon Dances)

Nishikawa Rinnosuke 西川林之助

Shinjō (Nara): Nhon Bunge1sha

269 p. 11lus. ABla GV 1695/.N58

A random collection of representative bon dances which are popular during the summer. Presents the song texts and for some of the dances, the musical scores. Includes brief coments on the origin and transitions of the dances over the years.

Geinō no ruten to hen'yō 䒧能力流転と变容

(Changes and Transformations of Performing Arts) Ikede Yasaburō 池田弥三郎

Tokyo: J1tsugyó no NLhonshe
234 p. 11lus.

A historical study of folk performing arts, with emphasis on origin and local environment, changes and transformations with the passing of time, speclal characteristics of the arts, etc. Includes discussions on past Interchange of arts between the Japanese malnland and Ryükyū Is lands, challenge of kabukt agalnst noh, relationshlps between 11terature and performing arts, etc.

Ceino ronsan 荒能論箱

(Collection of Essays on Performing Arts) Ed. by Honda Yasuj1 Hakase Rok1 KInenkal 古梯記念会编 Tokyo: Kinseisha 764 p. 111us.

馀正社

1976.

Ao1a PN2921/.G457
本田安次博士$$
16 .
$$ 
FOLK PERTORMING ARTS - GENERAI

A collection of 37 essays written by the disclples and acqualntances of Professor Yasujl Honda, an ethnologist, on the occasion of his 70th birthday. Essays are on foreign and Japanese performing arts with the focus on folk arts of Japan, Including local kagura (Shinto music and dance), taue-bayasht (rice-planting songs), ningyo shibai (puppet theater), regional noh and kyogen, etc.

Consists of four main sections. Section 1 discusses how folk performing arts are handed dom from generation to generation. Section 2 considera the various folk performing artg from a historlcal viewpoint. Section 3 notes how the place or the stage of performing arts changed over the years. Section 418 devoted to the perforiang arts of Okinawa.

Jishibal to minzoku 地芝居と民俗

(Local Theater and Folklore)

Gunji Masakatsu 郡司正幐

Tokyo: Iwasaki B1futsusha 岸崎美術杜 1971.

273 p. 111u8. Asia GR340/.M575

Examines the origin, development and special characteristics of Ilshibal (local theater). The first part discusses the general and aesthet 16 aspects of 11shlbal, Including its relationships with folklore, the spread of kabuki to outlying regions, itinerant theater, etc. The second part 18 a record of local theatrical events observed by the author.

922 Hana matsurt (Flower Festiva1)

Hayakawa Kotarō

Tokyo: Iwasaki Shoten

339 p. 111us.
花 祭

早川孝太郎 崖崎書店 Asia GR340/.M575

Based on the author's research, describes the various forms of performing arts, centered on the Flower Featival, whlch have been transmltted for generations in the areas now designated as Aich1, Nagano and Shizuoka prefectures. Consiating of two volumes, the work is amply 1llustrated. Vol, 1 provides background information on the Flower Festival, which is a religious function, dating back to the Middle Ages. Vol. 2 describer ritual dances and dengaku which are sald to preserve the original formo of the Flower Festival. 
FOLK PERFORMING ARTS - GENERAL.

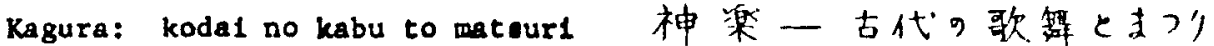

(Kagura: Songs, Dances and Festivals of Anclent Ages)

Ed, by Gelnōsh1 Kenkyūka1 芸能史研究会編

Tokyo: Hetbonghs

332 p. 11lus. (N1hon no koten geino, 1 日本9古典芸能，）

Asia PN2921/.N55/V.1

Depicts the kagura (Shintô music and dace) performed as a classic folk art in different parts of Japan as contrasted with mikagura (kagura of Emperor's court). Attempts to determine the origin, composition and evolution of kagura and its significant role in the history of Japanese performing arts.

924 Kasuga Ömlya Wakamlya on-sairel zu

春日大宮若宮御祭礼团 (Ceremonles at Kasuga Shrine, with Illustrations) Kasuga Jinja Shamusho 春日神杜衤䅂所 Nara: 1931. As 1a GT3405/. J3F84

3 v. $111 \mathrm{us}$.

A collection, in three volumes, of lllustrated records of ceremontes held at Kasuga shrine and Wakamiya of Nara, the birthplace of Yamato sarugaku. Serves as basic source materlals on religtous rituals from which performing arts developed. This work is a reprint of the origina 11742 woodblock print.

925 Kokuritsu Gekijo minzoku geino kỏen 国立㓺場民俗芸能公演 (National Theater: Public Performances of Folk Performing Arts) Tokyo: Kokuritsu Gek1jō 25 18sues. 国立劇埸 1970- 1980.

A collection of printed programs of folk performing arts staged at the National Theater in Tokyo. Includes performances on Japanese folk congs, Alnu dances, regtonal kabuk1 and puppet shows, etc.

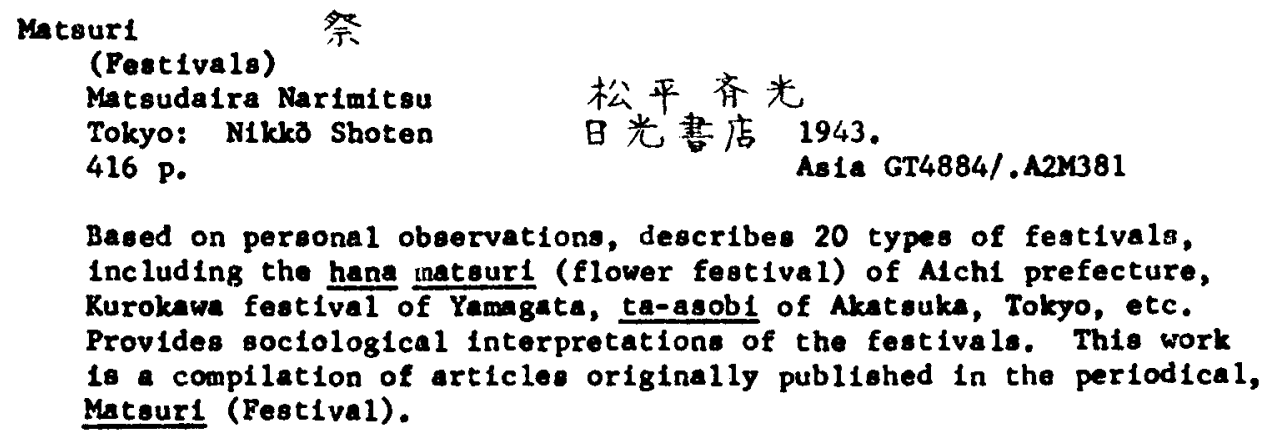


FOLK PERPORMING ARTS - GENERAL

927

MInshū no naka no dento geino 民腎のなかの伝統芸能

(Traditlonal Performing Arts of the People)

Sato Nobuo 佐解伸雄

Tokyo: Issolsha - 声杜

262 p. 111us.

As 10 GT4884/.A2S23

Exemines the role of the performing erts in the lives of the peopla with emphasis on local, regional arts. The maln fecets considered Include: festivals and annual events of different localities, several highly popular folk songs, stage arts such as noh, kabuk1, rokyoku and rakugo, the trend of performing arts, etc. A survey of the traditional performing arts as they exist throughout Japan today.

Min'yo kiko zenshū 民謡兹行全集

(Collection of Travel Accounts and Folk Songs)

Hattor 1 Ryutarō

Tokyo: Kawade Shobō

3 v. $\quad$ L11us.

服部部太郎

河出婁房 1962 .

As 1 a $\mathrm{M812} / . \mathrm{H} 38 \mathrm{Mb}$

A collection in three volumes, of accounts of travels made throughout Japan to record folk songs. The author made muslcal notat lons and to add a local flavor in introducting the songs, described the history, customs, geography, living conditions, etc. of the ares. Vol. 1 covers Hokka1dö, Töhoku, Kant $\delta$ and parts of central Japan. Vol. 2 includes the remaining parts of Chübu, and Kink1, Chügoku and Sh1koku. Vol. 3 takes in Kyüshū, Amani and Ryükyüs.

929 M1n'yō no onna 民言章の女

(Women in Folk Songs)

Naka1 Kojlrō

Tokyo: Jitsugyō no Nihonsha 1977 .

246 p.

As 1a PL748/.N32

Discusses the rolo and ignificance of women In Japanese folk songs from historical and cultural standpoints. Notes women's contributions to the development of folk songs, Including the goze (blind, female, itinerant aingera) of Nigata prefecture, ordinary women laborera singing as they work, professional singers of folk songs, etc.

$930 \quad$ Min'yo no tab1

(Folk Song Tour)

Saljo Yaso

Tokyo: Asah1 ShImbunsha 朝日新聞社

民蛋の病

202 p. 111 s.

As 1 a M3750 
FOLK PERFORMING ARTS - GENERAL

A dlary of the author, a poet, who traveled for a month, from June 28 , 1930, throughout western Japan to famlliarlze himolf with folk songs. This work introduces various folk songs from Nilgata to Nagasaki prefectures with emphasis on the author's impressions and observations during the trip.

931 Min'yö oboegak1 民謡觉嘒 (Folk Song Memorandum)

Yanagita Kunto 柳田国男 Tokyo: Sōgensha 刢元社 416 p.

1940.

As 1a ML3750/. Y35

Random thoughts concerning folk songs by an author who 1s a noted expert on folklore. The author belleves that folk songs were born because there was a need for then in the lives of the people. Comments on popular folk songs, including children's songs of Aktta prefecture in the north to ayago songs of Miyako Islands in the south.

Min'yō rekishi sampo 记淁楚史鿒步

(H1storical Survey of Folk Songs)

Ed. by Ikeda Yasaburō and Myao Shigeo 池田弥三郎，宮尾１1委編 Tokyo: Kawade Shobō Shinsha 4 v. $111 \mathrm{~s}$.

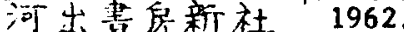
As 1 a ML3750/. 138

A collection, in four volumes, of over 300 folk songs, arranged from north to south, 1.e., from Hokkaido to OkLnawa. Emphasis 18 on the historlcal or 181 in of the songs. D1scusses, in detall, the local customs and manners which gave birth to the songs. Also traces the historical changes of the songs.

933 Minzoku geinō: füryü H1gash1 Nihon N18h1 N1hon 民俗䒧能 〈風流東日本，再日本〉

(Folk Performing Arts: Püryū East Japan West Japan) Bunkachō 丈 化市

Tokyo: 1974-1975.

2 v. 1llug. (Muke1 bunkazai kiroku, geinō-hen, 4-5 無形文化財 記鎳，芸能篇，4-5) As1a GV1695/.J35/1975

A collection, in two volumes, of classic, füryú (artlotically elegant) dances selected as part of the project to preserve Intanglble cultural assets of Japan. Vol. 1 covers eastern Japan, and Vol. 2, western Japan. Selections were based on: National Folk Performing Arts Exhibitions, 1952-1968, Reglonal Folk Performing Artg Exhibitions, 1959-1968, and Polk Perform1ng Arte Emergency Surveys, 1965-1967. The following format is used to introduce each plece: name of dance, loca 1e, when performed, detalls of dance, including 1 te ortgin, choreography, costumes, music, songs, etc., apecial features and remarks on the selection processes. 
FOLK PERFORMING ARTS - GENERAL

934

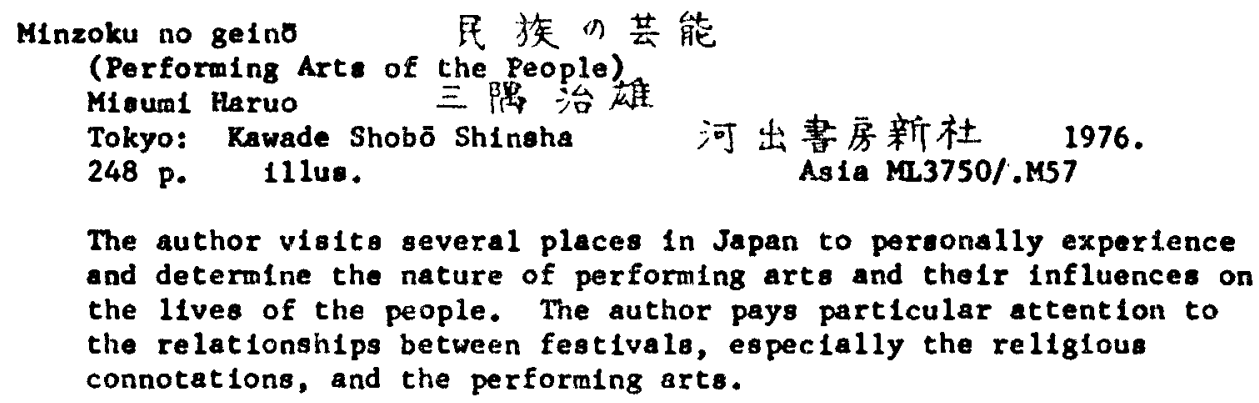

Richly lilustrated with sketches and photos, this work describes the varlous annual events held throughout Japan. Deals with popular events such as setsubun (bean-throwing ceremony), hina matsurl (doll festival), tanabata (star feotiual). Shint $\delta$ and Buddhist ritualo are not included. Although not directly related to performing arts, this work serves as a valuable reference to understanding of reglonal folk performing arts.

937 Nihon geinō no ghuryō 日本芸能 9 主流 (Malnstream of Japanese Performing Arts) Shiga 6o 志贺 用

Tokyo: Yuzankaku 雄山閏 1971.

374 p. 111us.

As 1a PN2922/.S5

A treatise on the origln of the traditional performing arts, kagura (Shinto music and dance) and noh. The author visits Hayato village, Kagoshime prefecture, and diecovers relice indicating the birth of hayeto kagura in this area. He evolves the theory that hayato kagura doveloped Into salbara and then to mikagura (kagura of the Emperor's court), whlch was influenced by hayato sarugaku, and then developed into noh. 
FOLK PERFORMING ARTS - GENERAL

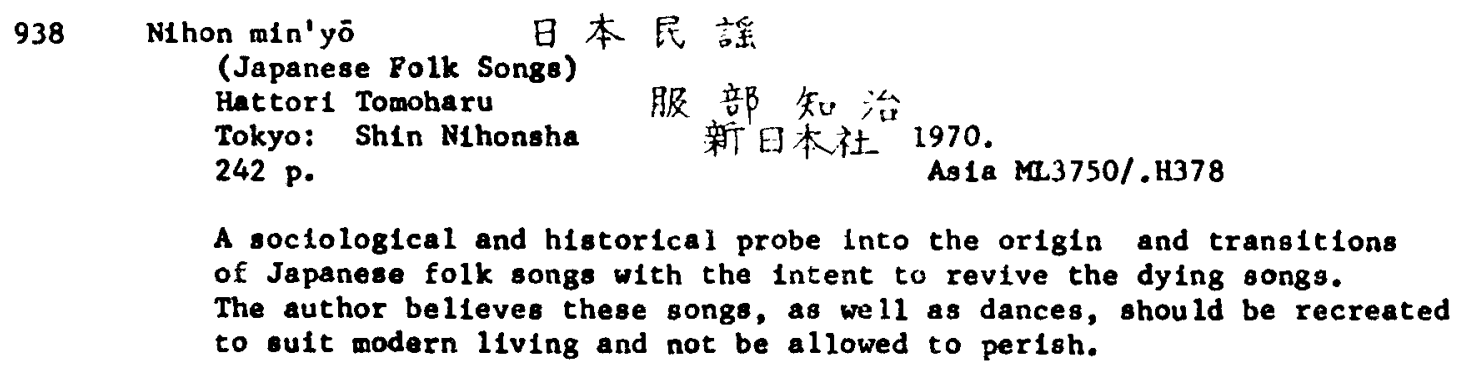

939 - Nihon min'yō buyō zenshū (Collection of Japanese Folk Songs and Dances) Sakakibara Kiftou Tokyo: Kin'ensha 2 v. $111 \mathrm{us}$.
日本民謡释踊全菜

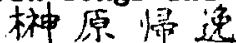
金闻社 1977 .

As 1a GV1695/.5244

A collection, In two volumes, of well-known songs and the accompanying dances. Vol. 1 is the eastern Japan edition and Vol. 2, western Japan. Each plece is presented in the following format: song texts, musical score, brief background Information and dancing instructions with dlagrams.

940

$$
\begin{aligned}
& \text { Nhon min'y jiten 日本民謡辞典 } \\
& \text { 幸二郎編 } \\
& \text { 東京堂 } 1942 \text { 。 }
\end{aligned}
$$

$424 \mathrm{p}$.

As 1a Ref. M1812/.N34

Discusses various aspects of Japanese folk songs and provides background and bibllographic information. Songs are arranged by syllablc order and in the following format: Name of song, lyrics and explanatory background inforwation. There 18 an introductory essay covering the past, present and future of folk songs. Songs are classified by types and prefectures. Appended are: "Llsting (322) of Folk Song Collections," "Annotated Bibllography of Folk Song Collections," and "Listing of singers."

941 Nihon min' yö fiten 日本民摆辞典 (Dictionary of Japanese Folk Songs) Rodera Yükicht Tokyo: Me1cho Rankōka1 名寒刑行会 1942. 274 p. Alla Ref. M1812/.K6N4

Jepen's flrst folk oong dictionary. Th1s work is a reproduction of the 1935 f1ret edition. Excluding Okinawa, covers folk songo of all of Japan. Brovides word definitions and song explanations. Arranged according to Japanese syllabary. Appended are a descriptive essay on folk songe and three types of indexes: general (oylleblc), prefectural and subject. 
FOLR PERFORMING ARTS - GENERAL

942

Nihon min'yō kyokushü 日本民謡曲集

(Collection of Japanese Folk Songs)

Ed. by Takada Sakuzö 高 $⿴$ 界 九三編

Tokyo: Kyōdö Ongaku Shuppansia 宾同暗集出版社 1955.

159 P. As1a M1812/.M543

A booklet of popular folk songs from Hokkaldō to Kagoshima prefectures. Presents mustcal ocores and lyrics. The Introductory section contains several photos of scenery and dances of varlous localities and dancing instructions with dlagrams.

943 N1hoa m1n'yō no hakken (D1scovering Japanese Folk Songs) Hattor1 Ryütarōo 服部篦太郎 Tokyo: Rironsha 理椧社 1958. 254 p. 11lus. As 18 M1812/.H38447

A record, in the form of a travel account, of folk songs collected by the author during his trips throughout Japan. The author notated the songs on musical sheets and photographed the locale. Places covered fnclude Trugaru of Aomor 1 prefecture, Sado Island of N1igata, Takach tho of Miyazak1, etc.

944 Nihon min'yō shikashū 日 本民謡詞龩集 (Anthology of Japanese Folk Songs) Ed. by Machlda Kashō Tokyo: Iwanami Shoten 445 p. I11us.

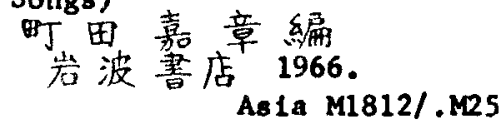

A selection of popular folk songs which have been generally cherished because of their catching tunes. Examples are Boran-bushi of Hokkaido, Tsugaru tongara-busht of Aomor1, yasuk1-busht of Shimane, Tabaruzaka of Kumamoto, etc. Presents the lyrics and brief backgound explanations of the songs. Includes mustcal scores for some of the songs.

945 Wihon min'yō talkan 日本民言大趉大矮 (Comprehensive Collection of Japanese Folk Songs) Nihon Hōsō Shuppan Kyöka1 日本放咲出版協会 Tokyo: 1952v. 1-5, 7-9.

A comprehensive collection, In 9 volumes, of folk songe of the various prefectures. The volumes are divided as follows: Vol. 1 on Tóhoku district, Vol, 2 on Kantō, Vol. 3 and 4 on Chübu, Vol. 5 on Kink1 and Vol. 6 on Chügoku, Vol. 7 on Shtkoku, Vol, 8 on Kyūahü and Vol, 9 on Kyưsha and Hokkaido. For each prefecture, there lo an introductory essay giving historical, geographical, economlc and cultural information, as backgound to the songs followed by muslcal scores with lyrics and rather detalled annotations. 
FOLR PERFORMING ARTS - GENERAL

946 Nihon min'yōtalzen 日本民㗝大全

(Comprehensive Collection of Japanese Folk Songs)

Ed. by Dōyō Kenkyūkai

Tokyo: Shun' yōsha

童蚯研究会編

$682 \mathrm{p}$.

春陽杜 1926 。

A comprehensive collection of folk songs of Japan, as well as Korea and Talwan, with emphasis on children's songs. Also includes folk songs concerning weather, manual labor, festlvals, etc. Arranged by geographical divisions and subdivided by subject content of songs.

947 Nihon minzoku geinō galron 日本民俗䒧能榴論

(General Survey of the Performing Arts)

Mouml Haruo 三隅治雄

Tokyo: Tokyodō 東京堂 1972.

283 p. As1a GT4884/.A2M48

Describes and analyzes folk performing arts from an overall standpolnt: aesthetic and theoretical considerations, historical developments and types, and the arts as performed in different parts of Japan. The author points out that folk performing arts originated and were maintalned in the dally living of the people and might be called group expressions to satisfy soclal needs. Therefore, a study of the arts would reveal much of the cultural history of the people.

948 Nihon minzoku geinō jiten

(Encyclopedia of Japanes

Folk Performing Arts) Ed. by Bunkachōo 丈化庁監修

Tokyo: Dallch1 Hōk1 Shuppan 第一法規出版 1976.

1005 p. 111us. Asia Ref. GT4884/.A2N475

A complation of detalled information on 980 important performing arts and festival events of Japan. For each event, provides such Information as name, location, performance.perlod, historical and present status, coatumes, song texts, if any, transportation to site, etc. Arranged by prefectures, Including OkInawa, and subdivided by syllablc order of names of events.

949 Nihon no tin' yö

日本9 民謡

Asano Renj1

Tokyo: Iwanam1 Shoten 岩波咅店 1966.

217 p. $111 \mathrm{us}$.

A study of the orłg1n, composition and historlcal changes of Japanese folk songs. Attempts to grasp the special characteristics of the congs and to provide backgound information which will assist in the underatanding of present-day folk songs. 
FOLK PERFORHING ARTS - GENERAL

950

$$
\begin{aligned}
& \text { Nihon no m1n'yō 日本の民謡 } \\
& \text { (Japanese Folk Dances) } \\
& \text { Nakayama Yoshio 中 4 義夫 } \\
& \text { Tokyo: Nihon Bungetsha 日本文苔社 } 1964 . \\
& 656 \text { p. 111us. As1a GV1695/.N34 }
\end{aligned}
$$

A comprehensive collection of folk dances arranged geographlcally from south to north, 1.0., from Kyushu to Hokkaldō, Covers the well-known dances and songs of each prefecture except Okinawa. For each dance plece, the song lyrics, dancing instructions with diagrame and a brief explanation are given.

951 Nihon no min'yo 6 本9民謡

(Folk Songs of Japan)

Tokyo: Nthon Hos Shuppan Kyoka1

226 p. 111us. As 1a ML3750/.T32

Wh the intent to discover how people used folk songs, the author delves into the elements that make up folk songs and describes the origin, types, transitions and changes in usage of folk songs. He also notes the current boom in their popularity and presents his opinions on the future of the songs. (Folk Songs and Performing Arts of Japan) Ed. by Tóyö Ongakuka1 東洋音薬会編

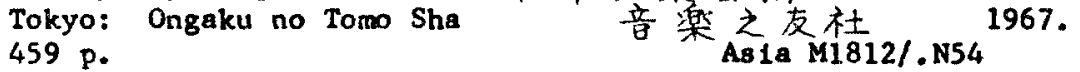

The first in the 12-volume Serfeg on Regearches in Aglan Music edited by "The Soclety for Research In ABlatic Music." Contalns four essaya: "Ethnomusicology in Japan," by Tomiko Rojima, "A Study of the Origin of Folk Songs," by Kasho Machida, "The Genealogy of Folk Theater and Music," by Haruo Misumi, and "Kagura and Matsur1-bayash1 in Edo," by Yasuj1 Honda.

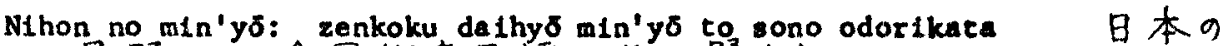

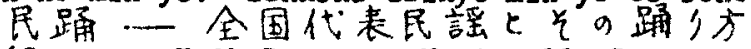
(Japanese Folk Dances: Nationally Representative Folk Songs and How to Dance them) Nakayama Yosh10 Tokyo: Tsuru Shobo 中心椠态 1955. 265 p. 111 . As 1a GV1695/.N3

A collection of representative folk songs which have originality and which can be danced by amateura. Most of the eongs were selected because they had been recorded and can be easily practiced. For each piece, there is a musical score, lyrics, dancing instructions with diagrams and a brief historical explanation. 
(Handbook of Japanese Festival Events)

Ed. by MIyao Shigeo

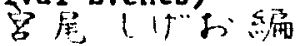

Tokyo: Shüdösha 修道杜 1968.

708 p. 1llus. As1a Ref. GT4884/.M58

A calendar of Japanese festival events, listing by prefectures, the varlous events hold from January through December of each year. Lists the dates, places and names of events. Also contains kana readings of unusual or difficult place names.

955 Nihon shomin bunka shiryō shüse1, da1-1-kan, kagura, bugaku

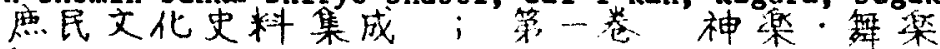
(Collection of Materials on Japanese Popular Culture, Vol. 1, Kagura, Bugaku)

Ed. by GeInōoh1 Kenkyüka1

Tokyo: San'1ch1 Shobō

$$
\begin{aligned}
& \text { 芸能史研究会编 } \\
& \text { 三一妻 }
\end{aligned}
$$
744 p.

A comprehensive work contalning source materlals for the study of kagura (Shintö music and dance) and bugaku (court music and dace). Contains an Introductory article on the or 1 gin, types and Importance of the source materials. Divided into $81 \times$ parts: mikagura (kagura of the Emperor's court), Izumo school kagura, Ise school kagura, shish1 kagura, materials concerning kagura, and bugaku.

Whon shomin bunka sh1ryö shüsel, dal-2-kan, dengaku, sarugaku

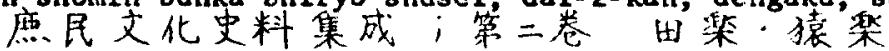

(Collection of Materials on Japanese Popular Culture, Vol. 2, Dengaku, Sarugaku) Ed. by Ge1nōsh1 Renkyūka1 Tokyo: San'tchl Shobo 789 Po

$$
\begin{aligned}
& \text { 莣能史研究会编 } \\
& \text { 三一㱏房 } 1974 . \\
& \text { AsLa PN2920/.N5/v.2 }
\end{aligned}
$$

A comprehensive collection of source materials on dengaku and sarugaku, precursors of noh. There is an introductory egsay on both arts explaining their or $\overline{1 g}$ In, historical developments, social features, etc. Source materials are documented and annotated.

957 RAyōshü 俚謡集

(Collection of Folk Songs) Mombushō 文部省

Tokyo: Kokute1 Kyokasho Kyodo Hamba1sho 国定教科萦烡同販売所 1914

781 p.

As 1a PL749/.R59 
FOLX PERFORMING ARTS - GENERAL

A collection of folk songs compiled in 1914 by the Miniatry of Education from materials submitted by the respective prefecturee. All of the prefectures are not covered since some did not submit materials. Songs for dances, festivals and celebrations are plentiful. Musical scorse are not included. Serves as bastc reference for research on folk cong8. Riyōshū shūi 俚言䍃集拾遗

(Collection of Folk Songa, Supplement) Takano Tatsuyuk1 and Otake Shiyō Tokyo: Rikugökan 六合官 366,108 p.

\author{
高野辰之，大竹紫葉 \\ 1915. \\ As la PL749/. R595
}

Supplements the Rlyōshü published In 1914 by the Mlnistry of Education. This supplement contains folk songs of Tokyo, Osaka and 13 prefectures which were missing from the 1914 edition. In addition, children's songs, love songs, etc. were newly added.

959 Selchō min'yōshū 正言周民詳 集

(Collection of Orthodox Folk Songs)

Ed. by Hogakusha 钣梁社

Tokyo: 1955-1956.

3 v.

A collection, in three volumes, of representative folk songs in Japan. Includes musical scores for shamisen, lyrics and a brief explanation for each plece.

\footnotetext{
960 Tauebayashi kenkyū 由㯖ばやし研究

(Study of Rlce-Planting Songs)

Uchida Ruriko 内田及尒

Tokyo: Yūzankaku 1978.

364 p. 111us. As La ML3750/.U3

The author applied the theory of Heat Europenn ethnomuelcology to the study of rice-planting songs. The work conslets of four sections: Section 1 ls a general discusaton of the lineage, regional classification, history, folklore, Itterature and music of rice-planting oongs. Section 2 analyzes, In detall, the lineage and chools of the songs. Section 3 describes the songs of Tokunoshima, Amamf Is lands and Rorea. Section 4 is a brief conclusion focusing on the songs of HiroshimaShimane prefectures, where they are $t 111$ prevalent, and relationships of the songs of these areas with those of other East and Southeast Asian countries.
} 
FOLR PERFORMING ARTS - GENERAL

961 Taue kayō to girel no kenkyō

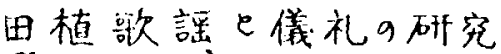
(Study of Rice-Planting Songs and Observances) Watanabe Shögo 渡 深 B $B^{7}$ 五 Tokyo: Miyal Shoten 1020 p. As1a $\quad 03750 / . W 37$

A dissertation on the or 1 in, transitlons, signiflcance, observances, etc. of rice-planting songs. Part 1 is a theoretical discusetion of the background of rice-planting songs. Part 2 analyzes the main toplcs and formalities of the songs described in Taue sōsht, regarded as the oldest collection of such songs. Part 3 takes up the literary nature of rice-planting songs which are the farmers' poetry.

(Collection of Rice-Planting Songs)

Takemoto Hiroo 竹本抎关

Tokyo: Myyal Shoten 三弥井暂店 1969.

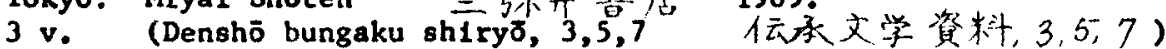
As 1a M1812/.T343T4

A collection, in three volumes, of rice-planting songs. Vol. 1 is a reproduction of four books of rice-planting songs, Vol. 2 1s a reproduction of five books, Including selections from Taue sosht, considered to be the oldest collection of such songs. Vol. 318 a reproduction of flve books from the former Izumo province (Shimane prefecture).

963 Zuka1 min' yō to odorikata

目解・民謡と踊分方

(Illustrated Folk Songs and Dancing Instructions)

ökura Suehiro 大倉末広

Tokyo: Daldö Shuppansha 1956.

315 p. H1lus. As 1a M1814/.048

A collection of representative folk ongs with interpretations, musical scores, lyrics and dancing Instructions. Examples are Sado okesa of Nilgata, Awa odor 1 of Tokush1ma, Asadoya yunta of Ok1nawa, etc. 
FOLK PERFORMING ARTS - LOCAL

964

Alnu no odort

(Ainu Dances)

Kono Hiromichi

Tokyo: Nire Shobo

64 p. 111us.

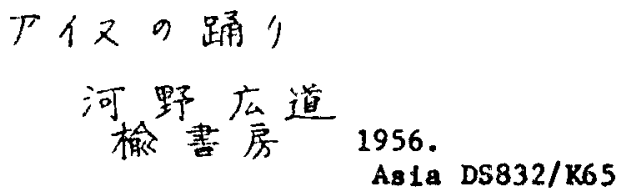

An orientation booklet, showing with photographs and brief explanations, the dances passed from generation to generation of the Alnu people of Hokka1do. (Study of Shintō Music and Dances of Böchōo) Misonoo Jisuke Tokyo: Miralsha 䘖圆生翁甫 202 p. 111us. 未来社 1972 .

A study of the orlgin, lineage and transitions of kagura (Shintó muslc and dance) of Böchö (Yamaguchi prefecture), the westernmost tip of the Honshü Is land of Japan. As background Information, discusges the local customs and living conditions of the farmers of Bōchō.

竹山津轻三味絈

山四前編

津倝書編 1976 .

Asia ML419/. T15C5

A photo album, with poems and articles, dedicated to Takahashl Chikuzan of Tsugaru ghamisen fame. Rocused on Chikuzan playing the shamlsen on atage and during practices but includes photos of persons and places in Tsugaru (Aomorl prefecture) associated with Chikuzan.

Ech1go goze nikk1

越後垶女日記

(Diartes of Goze of Mlgata Prefecture)

Salto Shin'ichi

Tokyo: Kawade Shobō Shinsha

355 p. 111 .

河出素原新社 1977.

AB La GT3650/. $\$ 34$

The author 18 an artist who became entranced with the goze (blind, female, itinerant singers) of Ech180 (N11gata prefecture) and apent over 10 years studying them. He came to know them as Individuals and traveled the ame route as they did in the Echigo countryside to learn about their activitiea, Including the farmers' houses used by goze as their abodes during travels. The author records their dally activities, through their diaries, in drawings and narrative descriptions. 
FOLK PERFORMING ARTS - LOCAL

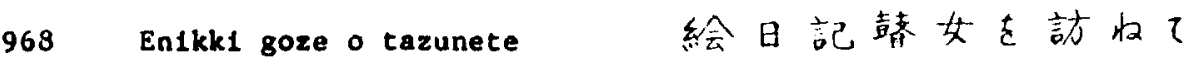 (Plctorical Diary: Vialts with Goze) Saltō Shin'ichi 省蕂

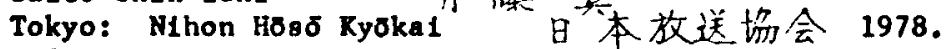
176 p. 111us. As1a FO ND1059/.S253A4
Similar in Intent but a somewhat different version of Echigo goze nikk1 (Diarles of Goze of Nilgata Prefecture) by the same author who Is an artist. This work 18 collection of over 200 drawings of goze (blind, female, ltinerant singers) with the author's diary in his on handwriting. He records his interviews with goze, primarily with Sugimoto Kikue, his travels through the countryside of Nilgata in the footsteps of the goze, his impressions and observations of the trials and tribulations of goze, etc.

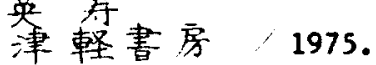

Introduces the native performing arts of Aomorl prefecture. Reveals the history and present status of songs and dances, Including noh dance, kagura (Shinto musts and dance), etc. of varlous parts of Aomorl prefecture.

Reminiscences, storles handed down for generations, worldly gossips, talks of her career as a goze (blind, female, itinerant singer) of Sugimoto Kikue (1898-) were recorded and transcribed for publication. Sugimoto Kikue of Takada, N1 Igata prefecture, is known for ainging goze songs, such as SaImon matsuzaka-bush1, and 1s considered an Intanglble cultural asset of Japan. Includes a brlef blographical sketch. 
BOLK PERFORMING ARTS - LOCAL

A collection of folk songs of Hokkaldo with explanetory comente on the songs as well as the locale which give birth to the songe. Divided into old and new folk sungs with detalled explanatione of the Esash1 ofwake, Soran-busht, etc. Which belong to the old group.

Hyögo-ken minzoku geinosh1 兵革界民俗莣能誌

(Record of Folk Performing Arts of Hyogo Prefecture)

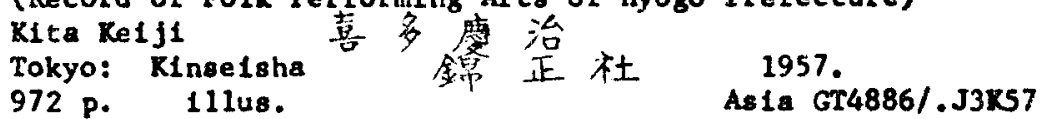

A record of folk performing arts, categorized into different groups, cultivated in Hyogo prefecture. Emphasis is placed on the description and analysis of $10 \mathrm{cal}$ customs and environnent in which the arte were born and how they were transmitted for generations. The different types of arts Include the taiko odorl (drum dance), kagura (Shinto mus ic and dance), noh and kyogen (comtc interlude), puppetry, kabukt, etc.

973 Hyüga min'yo $\theta$ 向民言垔

(Folk Songs of Hyüga)

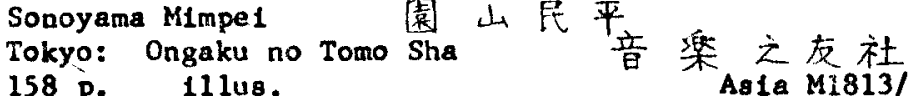

Ag1a Mi813/.565

A collection of 101 folk songs of the present Miyagl prefecture. Musical scores, lyrics and brief explanations of the ongs are given. Songs are categorized into four types: laborers's songs, songs for special events, songs to comfort and entertain and children'songs.

(History of Performing Arts of Ibarak1 Prefecture)

Ed. by Ibarak1 Bunka Danta1 Rengóka1 茨城丈化团体連合会編 Mlto: 1977.

649 p. 111us.

As 1a PN2925/. I25I25

Searches for the orlgin and traces the historical developients of performing arts of Ibaraki prefecture from anclent ages to modern tines. Discusses, in detall, the folk performing arts and folk songs of different parts of Ibarak1. Includes a section on the growth of Western music through the Melf1-Taishö-Shōwa periods.

975 Iwate-ken minzoku ge1nösh1

岩手㝠民俗芸能訫

(Record of Folk Performing Arts of Iwate Prefecture)

Mor1guchl Tari

Tokyo: Kinseisha

林口多里

1408 p. 111us.

錦 正社

1971.

As 1a GV1696/. I92M67 
The introductory section analyze the or $1 \mathrm{~g} \ln$ of certain folk performing arts in Iwate prefecture and discusses the varlous conditions under which these arts were tranamitted for ages. The arts are then described by different types, Including kagura (Shintō music and dance), nembutsu odort (Buddha dance), shisht and shika odort (11on and deer dances), bon dance, puppetry, etc.

(Matsumae Kagura, Unoffictal Shintō Event in Matsumae Castle)

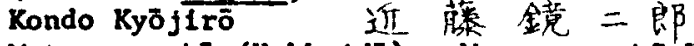

Matsumae-chō (Hokka1dō): Matsumae-chơ Kyōlku Ilnkai 松前时 教育委筫会 1964 .

209 P. $111 \mathrm{us}$.

As 1a BL2224.25/.K3K65

Records historical materials, Including song texts, dance petterns, descriptions of stage and costumes, etc. of the Matsumae kagura (Shinto music and dance). Traces the evolution of the kagura from generation to generation. Matsumae kagura was recognized as an official and significant Shinto event within the castle of the Matsumae domain which developed and cultivated Hokkaldo.

Nihon nl okeru minkan ongaku no kenkyū (Study of Folk Music of Japan)

Mizuhara nkōo水原渭江 Nagoya: Minzoku Bunka Kenkyūjo

1 v. 111us.

A study of the folk dance and song, ō-no-mai, of Wakasa (Fuku1 prefecture). D-no-mal has been transmitted for generations in the various shrines along Wakasa bay and considered to be the most important festival event in the agricultural comunitles of Wakasa.
日本によける民間音舁の研究

民俗文化研究所 1967. As 1a GV 1695/.M68
ML1gate-ken minzoku geinōshi 新潟瀑民俗芸能史 (Record of Polk Performing Arts of Nilgata Prefecture)

\section{Kuwayama Ta1ch1}

Tokyo: Kinse1sha

956 p. 111us.

Considered a treasure trove of folk performing arts, Nigata prefecture. has numerous types and many varlations of the sams type, depending on the locale. The arts include bugaku (ohrine music and dance), spectal Shintō events, dengaku, shishimal (1ion dance), faryü, puppetry goze songs, etc. Appended 18 a list of the arts considered by the Nilgata prefectural government as Intanglble cultural assets. 
POLK PERFORMING ARTS - LOCAL

979

RIkuzen-hama no holn kagura 陸前㴧 9 法EP神楽

(Kagura Performed by Mountain Aocetic: of Rilaren-hama)

Honda Yasuj1

Kyoto: Rinsen Shoten 踦 11 書店 1975.

580 p. 111u8. Aola BL2224.25/.K3H66

This type of kagura (Shintö music and dance) was first performed by höin or yamabushi (mountain ascetics) practicing shugendō and atill remains as a folk performing art of Myagl and Iwate prefectures. This is a comprehenstve, scholarly work on höln kagura of Rikuzen-hama (northern prefectures) by a famous expert on folk performing arts. First published in 1934. Includes a number of old documents and sctual scripes.

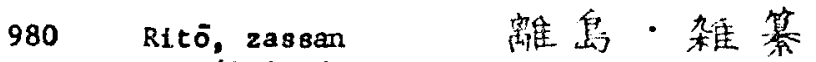

(Islands: Miscellaneous Collection)

Honda Yasuj1 本田安次

Tokyo: Mokuf1sha 木耳社 1973.

1361 p. 11lus. As 1a GV1695/.045H65

Comprised of two parts. The first part is a collection of the folk performing arts of Ryükyū and Izu Islands. The second part discusses kagura (Shintō music and dance), festival events, Edo kiyart (Edo lumber carriers' songs), etc. The Individual performing arts are presented through concrete examples, such as scripts, song texts, etc. There are explanatory essays for some of the arta.

981 Saitama-ken minzoku geinōsh1 埼王泪民俗䒧能誌 (Record of Folk Performing Arts of Saltama Prefecture) Kurabayash1 Shōji 合林正次 Tokyo: Kinseisha 錦正杜 1970 . 116 p. 111us, AsLa PN1582/J3K8

Describes the various types of folk performing arts which were nurtured and carried on in Saltema prefecture. The performing arts include shlshima1 (1ion dance), kagura (Shinto mustc and dance), nembutsu odor1 (Buddha dance), bon dance, puppetry, etc.

982 Shimaguni no uta to odor1 悲国の㖵と踊

(Songs and Dances of Is lands)

Tanabe Hisao 田证雄

Tokyo: Isobe Köyödō 硪部甲陽堂 1927.

274 p. 111us. As1a M1812/.T35

To conduct a systematic research of Oriental music, the author visited the is lands of Izu Ōshima, Sado, Karafuto, Ryūkyüs, Taiwan, etc. This work la a record of his muslcal survey and observations made during the trips. 
FOLK PERFORMING ARTS - LOCAL

983

Tōhoku min'yōshū

来北印謡华

(Collection of Folk Songs of Northeastern Japan)

Ed. by Nihon Hōsō Kyōkai

Tokyo: 1942-1963.

3 v. (v. 1-3)

Asia $M 1813 / . T 58 N 56$

A collection of musical scores and lyrics of folk songs of northeastern Jepan which 1s rich in folk performing arts. The area consists of Aomor1, Iwate, Yamagata, Myag1, Fukushima and Akita prefectures. An explanatory essay of the folk songs of each of these prefectures is Included at the end.

Toyama no minzoku geino

$$
\text { 也やまの民俗莣能 }
$$

(Folk Performing Arts of Toyama Prefecture)

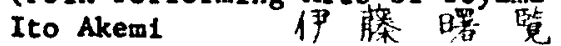

Toyoma: Kita Nikon Shimbuneha

362 p. 11lus.

圤，日本新聞社

1977.

As 1a GT4884/.A3T694

Surveys the folk performing arts of Toyama prefecture from a religious standpoint. Consists of three main sections. The first discusses the Shintō and Buddhist significance of festivals. The second considers the origin and historical traditions of performing arts. The third takes up the relationships between religlous falth and performing arts. Though religious aspect is emphasized, the various types of songs and dances are described concretely.

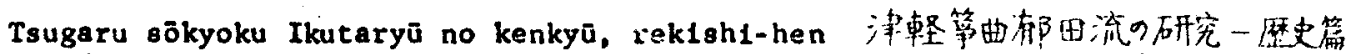
(Study of Ikuta School of Tsugaru Koto Music, History Edition)

Kishibe Shigeo and Sasamori Takefusa 岸边成雄, 悹森侓英 H1rosak1: Taugaru Shobo 津軽热序 1956.

318 p. 11lus.

A study of the Ikuta school, an old school of koto melc, which had been transmitted from generation to generation In the Tougaru district of Aomorl prefecture. The study is based on old documents, genealogies, musical scores, etc., pertaining to Ikuta school, which were newly discovered in Hirosakl clty of Aomorl. Reveals the opeclal features, historical evolution, etc. of the Ikuta school. Also touches on the contribution of the new discovery to historical studies of koto music.

Watasht wa goze: Sugimoto Rikue den

わたしは馨女一杉本招工伭

(I am a Goze)

Oyama Mahito

大山真人

Tokyo: Ongaku no Tomo Sha

318 p. Illus.

音留之友社 1957 .

A record of her 11 fe atory as related by Sugimoto Kikue (1898-), a goze (blind, female, 1tinerant inger) of Takada, Nilgata prefecture. She spent over 70 years of her life in the opecial female communty of goze and 18 now considered an Intanglble Cultural Asset of Japan. 
FOLK PERFORMING ARTS - RYŨKYŨ

Anani-Ōsh1ma min'yö kyokushū 奄見大島民謡曲集

(Collection of Folk Songs of Amaml Is lands)

Kazar1 Elkichl and Kazar1 Norlo

Naze: Nantō Bunka Kenkyüjo

39 p.

文英吉。丈紀雄

南息文化研究所 1954 。

Collection of 32 folk songs of Amani Islands, categorized into four groups: ordinary folk songs, August dance songs, hand dance songs and children's songs. Each page has the musical score, lyrics and annotative comments on the particular song.

Hyōon hyōshaku Ryüka zenshū

標音評积琉歌全集

(Complete Collection of Ryukyuan Poems with Pronunciation Guides and Annotations)

Shimabukuro Se1bin and Onaga Toshio 烏袋盛敏，翁镸俊郎 Tokyo: Musashino Shoin 武蔵野書院 1968 .

$737 \mathrm{p}$.

A comprehensive collection of 3000 Ryüka (Ryukyuen poems) with katakana and romanized readings in Ryukyuan language. Accent bymbols or stress marks are also shown. There are word definitions and interpretative annotations for each song. There are three types of Indexes: by phrases in the 8-8-8-6 format of the songs, by writers and by subject of the songs. As examples, two sonosheets of Ryūka are enclosed at the end. Th1s work was published to augment the weakness of ShImabukuro Selbin's 1964 work, Ryüka taikan (Comprehensive Survey of Ryūka), which did not contaln pronunciation guldes to the Ryukyuan language (Shuri dialect).

Karā Okinawa no uta to odor 1

力

(Songs and Dances of Okinawa in Color)

Ed. by Sakuda Shigeru

Naha: Gekkan Okinawasha

135 p. 1llus.

传久田筧編

月刊沖繒社 1974 。

Asia GV1696/.045K32

Introduces songs and dances of OkInawa. Dances are shown in color photos. Song lyrics are given kana readings in Ryukyuan language. Contains brief explanations of the songs and dances and the places where they are popular.

990 Köhon Omoro sōsh1 (Text Omoro Söshi)

$$
\text { 校本的毛々うし }
$$

Ed. by Nakahara Zenchū and Hokama Shuzen 仲原善忠，外阳守善編 Tokyo: Kadokawa Shoten 816 p.

角川曺店 1965 As 1a PL762/.056N35 
FOLX PERPORMING ARTS - RYOXXN

A revised reproduction of Omoro sōghl. Each page is arranged in three horlzontal column, with the top consisting of headnotes, the center containing the revised text in block printing and the bottom presenting the reprint of Nakayosh1-bon in calligraphic writing.

A detalled explanation of omoro 18 given at the beginning of the book. A valuable primary source for study of Ryukyus.

991

$$
\text { Kok1n Ryūkashū 古今琉歌集 }
$$

(Collection of Anclent and Modern Ryukyuan Poems) Ryükyū Shiryō Kenkyüka1 Naha: 1971.

$1 \mathrm{v}$.

Revised and reprinted edition of Kokin Ryūkashü published during the mid-Me1fi period or late 19th century. A collection of 1707 poems, divided into categorles such as spring, sumer, fall, winter, love, etc. Very brief headnotes are included. 舞踊 9 型と組踊乡五組

(Classic Ryukyuan Dance Patterns and Five Pieces of Kumlodor 1 ) Naha: Cekkan OkInawa Sha

月刊沖亚社

1972.

422.p. 111us.

As 1a FO GV1696/.R9K67

With the use of photo 1llustrations, detalled descriptions are given of the patterns of 24 classic Ryukyuan dances and five pleces of kumiodor 1 (Okinawa musical drama). The meaning, speclal features, costumes, etc. of each dance plece are noted. Blographical sketches and color photos of the dancing figures of 24 representative performers of Ryukyuan dances are given at the beginning of this follo-sized work.

A compllation of atage scripts of five pieces of kumiodor 1 (Okinawa musical drama), Including Gosamaru adauch1, Koko no mak1, etc., written by Tamagusuku Chōkun (1684-1734). The stage scripts are arranged In three horizontal columns to the page, with the top column noting tage appearances with use of diagrams, the center containing the dialog and the bottom, acting directions. The dialog has romanized readings in Ryukyu language. 
FOLK PERPORMING ARTS - RYŪXYŪ

994

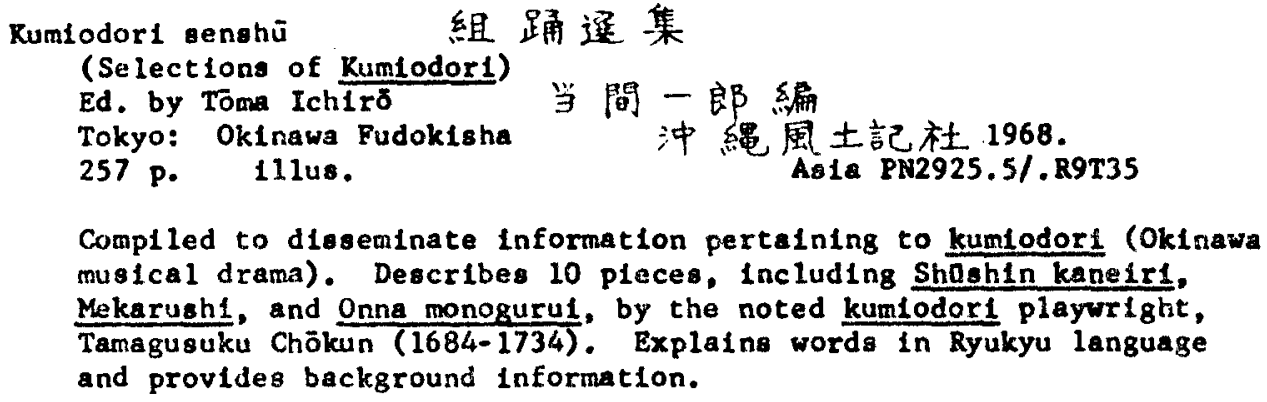

995 Kumiodorl temizu no en no kenkyū 組踊手木9絊の研究 (Rumlodor1: Study of Temizu no En)

A compllation of the author's essays on Okinawa, centered on commentarles on the kumiodori (Okinawa musical drama) called Temizu no en written by Heshikiya Chöbin. Includes an article explaining the origin and features of kumiodort.

MInzoku geInō zenshū 民俗芸能全集

(Complete Worko on Folk Performing Arta)

Yamauch1 Selhin L内 盛涁

Tokyo: Minzoku Gelnō Zenshū Kankß̋kal 1959.

6 .

民俗芸能全集刊行会

As 1a M340/.Y32

A series of research monographs on the mustc and performing arts of Ryukyus. Vol. 1, "The History of Musical Culture In Ryukyu" (Note: English titleg taken from originals) provides an introductory, general description of the historical development of nusic and performing arta. Vo1. 2, "Nation and the Mode: Based on the theory of 'mode of a fifth" "18 a technical discussion of folk songs. Vol. 3 presents "Dance of Ryukyu and Self-defense Dances." Vol. 4 1s a "Study of Ballads and Tunes of the Ryukyuan Dynasty." Vol. 5 takes up "Japanese Classic Note of Koto Mualc Remaining in Ryukyu," and Vol, 6, "Note of Royal Music Jansi Ryū in Ryukyu." 
FOLX PERFORMING ARTS - RYŨXYU

$$
\text { Miyakojima no kamiuta 字 } \frac{1}{5} \text { 是" }
$$

(Divine Songe of Miyako Is lands)

Hokama Shuzen and Shinsato Kōshō

Tokyo: San'1ch1 Shobö

$$
=- \text { 战 }
$$

外間字普，新里幸昭

349 p.

1972.

Ag ia PL886/.0542M5

A compllation of kamluta (divine songs) transmitted for ages in Myako Islands. Kamluta includes songs about the descent of delties on Miyako, birth of the child of god, establishment of villages, etc. Generally divided Into song categorles and each page 1a arranged in three vertical columns: left column contalns romanized readings In original Ryukyu language, the center gives the kana readings and right column the present Ryukyu language and standard Japanese. Explanatory commentaries are included at the end of the work.

A study of the origin and development of epic and lyrical songs in the Ryukyu Is lands (Southern Islands). Delves into the relationships between the growth of Japanese literature and evolution of songs in the Southern Islands. Describes Omoro sosht, the oldest collection of poems in OkInawa, complled during the $16 \mathrm{ch}$ and 17 th centuries.

1000 Nihon bungaku kara mite Ryuka gairon 日本文学加見た琉歌概論 (Comprehensive Survey of Ryukyuan poems from Japanese Literary Standpoint)

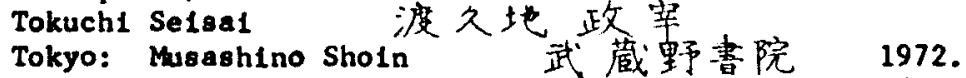
350 p. As1a PL886/.R92T66

From the standpolnt of Japanese 11terature, analyzes Ryurka (Ryukyuan poems) and coments on 1 ts origin, form, literary features, beauty, Influence of waka poetry, etc. The author notes that Ryuka, a 30-syllable poem with 8-8-8-6 phrase format, began to be composed from around the 15th century and with the introduction of shamisen In the 16 th century, Ryake was set to music and sung. There is a comparison of Rydke with omoro and the author points out the theory that Ryulke developed from omoro is galning acceptance. Ryukyu reading 1. given in kana for congs presented in the work.

Nhon shomin bunka sh1ryo shūse1, dal-11-kan, Nanto geino

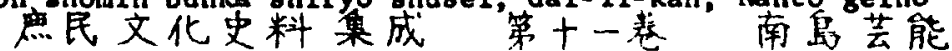
(Collection of Materials on Japanese Popular Culture, Vol. 11, Performing Arts of Southern Is lands)

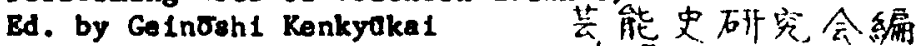
Tokyo: San'1chi Shobo $\equiv$ - 整序 1975. $703 \mathrm{p}$. As 1a PN2920/. N5/v. 11 
FOLK T'ERFORMING ARTS - RYÜRYŪ

A voluminous work conslating of an Introductory, historicel survey of Okinawa performing arts and four divisions: kumlodori (nuelcel drama), kagekt (opera), puppetry and kyogen (claselcal comedy), and songs and dances. Each division is introduced by an explanacory essay. Song and dance lyrics, opera dialog, puppetry and krögen texts, etc. are given. There are no kana readings of Ryukyu language and no annotative coments.

1002 Ok1nawa dōyōshū 冲䋥童謡集

(Collection of Okinawa Children's Songs)

Shimabukuro Zenhatru 焦笠全

Tokyo：Isseisha … 誠杜 1934 。

240 p.

A.s 1a M3750/. 555

A collection of Okinawa children's songs with translations of Ryukyu language to standard Japanese and simple explanations of the songs.

1003

Ok1nawa gelno shiwa 沖昰芸能史話

(Historical Account of Okinawa Performing Arts)

Yano Teruo 矢野糔雄

Tokyo: Nihon Hösö Shuppan Kyökai 、日本放送出版须会 1974 .

454 p. fllug. As1a PN2925/.04Y3

A rambling account of the development of performing arts in Okinawa. The purpose of this work was not historlcal research but an informal narrative in pralse of the diversifled nature of Okinawa performing arts. Discusses the enclent dances, birth of kumlodort (musical drama), introduction of shamigen music, kysgen (classical comedy) and kabukl, development of modern dances and plays, etc. A chronology of the performing arts in OkLnawa is appended.

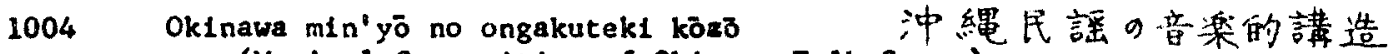
(Musical Composition of Okinawa Folk Songo)

Iwagaml Gyonin 岩上 行忍.

Tokyo: Ongaku no Tomo Sha 1962.

131 p.

Folk songs of Okinawa were sound-recorded and scored on muslcal sheets for analysis. Discusses the composition, tonsl system, melodies, rhythm, etc. of OkInawa folk conge. (Festivals and Performing Arts of Okinawa) Tōma Ich1ro 当閚 - 郎 Tokyo: Tuzankaku 雄山周 1976. 234 p. $111 \mathrm{us}$. As 1a GT4884/.A30387 
FOLK PERFORMING ARTS - RYŪKYŪ

OkInawa performing arts can be generally divided into two types. One is the popular arts consisting of group performances, including those staged as offering rituals during festivals. The other 18 the royal court arts of classic songs and dances created during the monarchical period of the Ryukyu Islands.

Okinawa no min'yo 沖綶 9 民謡 (Folk Songs of OkInawa)

Sugimoto Nobuo 杉本信夫

Tokyo: Shin Nihon Shuppansha

250 p. $111 \mathrm{us}$.

新日本出版社 1974 .

A81a M1812/.S84505

Divided Into two parts, chlldren's songs and folk songs, and subdivided Into sections on Okinawa, Mlyako and Yaeyama. Presents musical scores, lyrics with kana readings in Ryukyu language, explanatory comments on the songs with particular attention to special musical features and general backgound information, including the local color, composer, etc. to deepen the understanding and appreciacton of the songs.

1007 Ok1nawa no min'yō to kash1 kaisetsu 冲会9民謡と歌詞解説 (Okinawa Folk Songs and Explanations of Lyrics) Arashiro Tokusuke 新城著㭲 236 p.

As 1a ML370/.R9S35

This complation of 64 songs from throughout OkInawa adheres to the pollcy that folk songs should not be altered with new techniques but should be transmitted, as they were sung in the particular locality, without any changes in words and pronunciation. The meaning of each song is explatned and backgound Information is given. For each plece, kana readings are given as the lyrics are pronounced in Ryukyu language.

OkLnawa ongaku sömokuroku (General Index to Okinawa Music) Takaesu Yosh1h1ro
Naha: OkInawa Tafmusu Sha 高江洲義宽
1 v. Illus. 冲䋥，音榡忩目銤

Vol. 3 (Note: Asia Collection holds only this volume) is the "recording index" (the other two cover documentary materiala) and 11ats 1784 phonorecords and 3071 tapes, for a total of 4855 OkInawa songe. Arrangement of records 18 by Japanese syllabary, with a oupplementary section arranged by recording companies, and the tapes are by organizational or ladividual owners. Types of songa, names, performers, recording compantes, Identification numbers, etc. are given for each item. 
FOLK PERFORMING ARTS - RYOWKYU

1009

Orooro sōsht jiten sōsakuín

かもらううし辞典総索引

(Dictionary and General Index of Omoro Sosh1)

Nakahara Zenchū and Hokama Shuzen 伸原善忠，外間守善

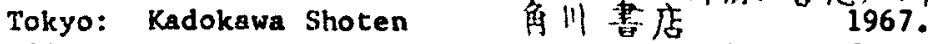

566 p.

As La Ref. PL886/.R92047

A dictionary and general Index of Omoro 8 bsht which 18 considered the key to Ryukyuan studies. The dictionary-index compilation is based on kohon omoro soshi (Text Omoro Soshi) by the same authors and published in 1965 by Kadokawa Publishing company. Arranged according to Japanese syllabary.

1010

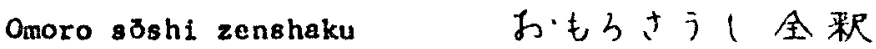

(Comprehensive Interpretations of Omoro Sosht)

Tor1goe Kenzaburō 鳥越密三郎

Osaka: Seibundō 㳻文堂的 1968 .

5 v.

As 1a PL886/.R92T67

Omoro sōsh1 is the oldest, complete collection (22 volumes, 1553 verses) of Ryukyuan poems that were sung in the Amami and Okinawa Is lands from around the 12 th to 17 th centurles. Vol. 1 of the Omoro söshi was complled in 1531 and Vol. 21 in 1623. Date of completion of Vol. 22 is unknown. Th1s work is a study of the Omoro soshi and the Individual omoro. For each omoro there are interpretative comments. There is an index, by phrases, in the 5th volume. This work is an indispensable primary source of research materials on Okinawa history, etymology, religion, folk performing arts, etc.

1011 Ryüka gensh1kō: shlmauta no sekai 琉歌么視行一舄方たの世界 (Okinawa Songs and Vislons: World of Island Songs)

Takenaka Tsutomu 竹中学

Tokyo: Tabata Shoten $\quad$ 烟意店 1975.

$453 \mathrm{p}$.

As1a ML.3750/.T267

Based on four articles, Including "The History of Chondara-bush" and "Irlomote, the End of Wind and Waves," previously published by the author. Contains new 1tems, all focused on Oklaawa songs.

1012

Ryüka no kenkyü

(Study of Ryukyuan Poems)

Misato Tomoyoshi

琉歌。石年

Naha: Ryūkyū Bunkyō Tosho

$261 \mathrm{p}$.

是里朝鹿

琉球文教国喜 1966 .

As La PL886/. R92M57

A collection of 45 Byüka, selected because they contain phrases which have ralsed questions in their interpretations. Arranged according to the following format: Ryūka with kana readings in Ryukyu language, translation Into standard Japanese, word definitione and explanatory comments. The latter makes reference to Man'yosha, Kokinsha, other Ryūka, kumiodorl, etc. 
FOLK PERFORMING ARTS - RYŪKYŨ

1013 Ryüka ta1kan 琉歌大鹳

(Comprehensive Survey of Ryukyuan Poems)

Shimabukuro Seibin 島货盛敏

Naha: Ok1nawa Talmusu Sha 沖㬎果タイムス社 1964.

634 p.

As1a PL886/.R92S352

Ryüka is a 30-syllable verse, In four pharases of 8-8-8-6 format, of Ryukyu. This work $1 \mathrm{~s}$ a comprehensive collection of 2891 Ryüka. The name of the poet, word definitions, song interpretations and explanatory notes are included. However, the readings in Ryukyu language are not given. Arrangenent is by song categorles. There are indexes by phrases, writers and subjects of 8 ongs.

1014 Ryūke tsurezure 琉 歌つれつ“川

(Random Thoughts on Ryukyuan Poems)

Ish1no Relichisō 石野往一郎

Tokyo: Tōhö Shobo 東邦書房 1973.

213 p. 11lus. Asia PL886/.R918

Selects over a hundred toplcs pertaining to OkInawa and eltes Ryoka (Ryukyuan poems) which has the toplc as the central theme. The author, Ishino Reilchiro, then presents essay-type explanations based on his personal experiences and Impressions. There 18 a full-page sketch facing the page containing the song and narrative.

1015

Ryükyü buyō no kiroku

玩球舞踊9記金录

(Record of Ryukyu Dance Performance)

Toyohira Ryöken 淟平良䩀

Naha: Okinawa Bunka Kyōka1 沖䌁文化協会 1955.

232 p.

Aв1a GV1696/.R9T6

Record of the Ryukyu dance performance staged in Tokyo during the 10th Art Festival (1955) sponsored by the Minlstry of Education. Includes the dance program, performers, reviews in news media, reactions of spectators, etc.

Ryūkyri no mln'yo 琉球の民謡

(Polk Songe of Okinawa)

Ranal Rikuko 金井喜久子

Tokyo: Ongaku no Tomo Sha 音㷊之友社 1954.

1 v. 111us. As 18 ML3750/.R35

Divided into two parts: molcal scores and explanatory narrative. Presents the history of folk songs and special characteristics of music of Okinawa. Contains 79 musical scores and for each plece, there are translations of the Ryukyr language to atanderd Japanese and explanatory notes. An Oklnawa muslc chronology 1s appended. 
FOLK PERFORYING ARTS - RYŨYYŨ

1017

Taramato no hachigateu odori
(August dance of Terema Is land)

Ioland)

Tarama- on Bunkaza1 Chōsa IInka1 多良間村文化財調查委員会

Ta1ra: Tarama-8on Yakubs 多良間村役場 1975.

94 p. 11lus. As 1a GV696/.T37

An orientation pamphlet explaining the hachlgatsu odorf (August dence) of Tarama Iolend. From its contents, the dance cen be divided Into two categorles. One can be consldered as a folk dance which origlnated on Tarama Island. The other 18 the classic kumlodort (muslcal drama) which was brought from the main OkInawa Island. Folk dances of Nakasugt and Shlokawa villages on Tarams are also included. There are black and white photo lllustrations of the dances, costumes, accessorles, etc.

1018 Yaeyama koyō 八重山古言蛋

(O1d Folk Songs of Yaeyama)

Miyara Tōso and Miyara Choho

Tokyo: Kyסdo Kenkyüsha

2 v. $($ v. $1-2)$

宫良当壮，宫良喜包

良土研究社。1928。

As 1a ML3750/.M56

A collection, in two volumes, of folk songs which had been transmitted for ages in Yaeyama. The songs are presented in the following format: annotated musical score, then, lyrics in Okinawa dialect and standard Japanese, followed by explanatory comments. This work is significant as one of the earlier collections introduclag Yaeyame folk oongs. Kana readings are given for Ryukyuan words.

1019

Yaeyame koyō > 重山古謡

(Old Folk Songs of Yaeyama)

KLshaba Eifun 喜舍場永洵

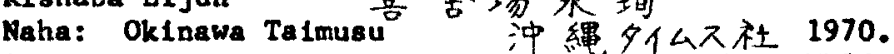

2 v.

As 1a ML3750/.K48

A compilation, in two volumes, of over 230 old folk songs of Yaeyama Is lands. A companion work to Yaeyama min'yoahi (Compllation of Yaeyama Polk Songs) by the same author. Yaoyama min'yohi covers fushlute while this work is concerned with rödöuta, namely, ayo (or aru). L1raba, yunte and yunsto. When ingling these songe, the musical time is kept by hand-clapping. The songs are presented in Ryukyu language and standard Japanese, and explanetory comentarles are included. An interesting feature 18 the 1isting of 17 speech sounde pecullar to the OkInawa dialect. 
FOLX PBRPORMLWG ARTS - RYŨKYŨ

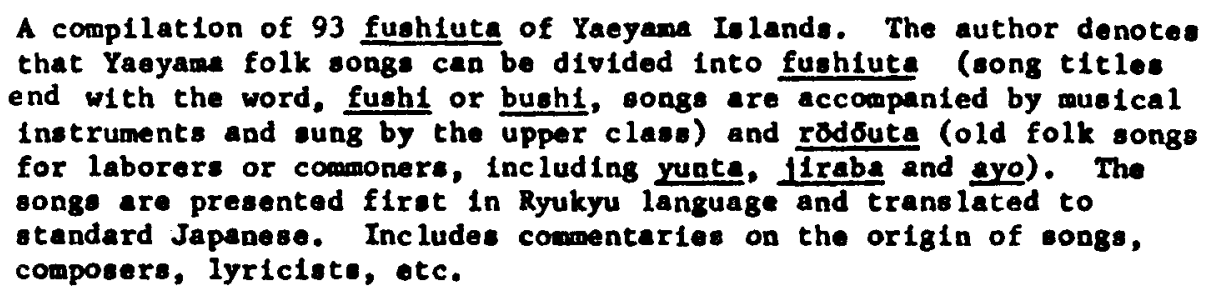

A compllation of 93 fughlute of Yaegame Ielands. The author denotes that Yaeyame folk songs can be divided into fushluta (song titles end with the word, fusht or busht, Bong are accompanied by musical oonge are presented firet in Ryukyu language and translated to composers, Iyriclete, etc. 
AUTHOR LNDEX

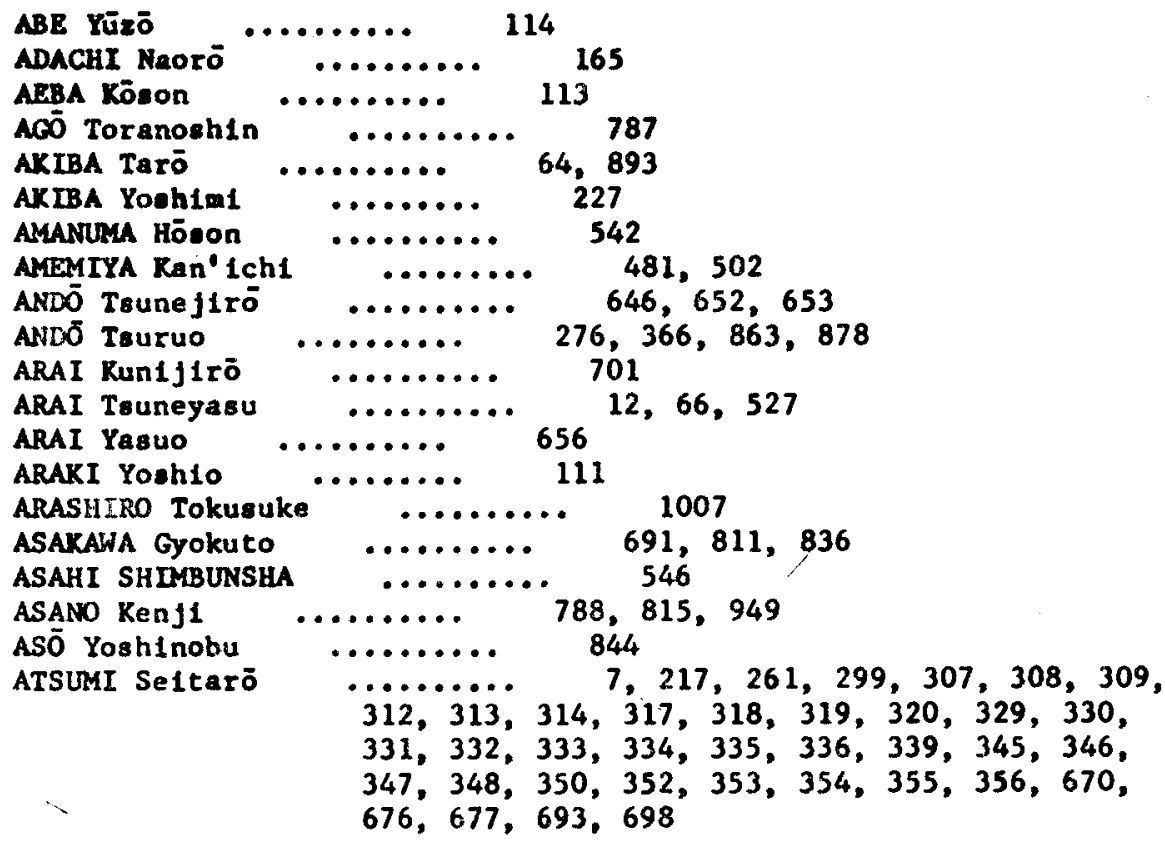



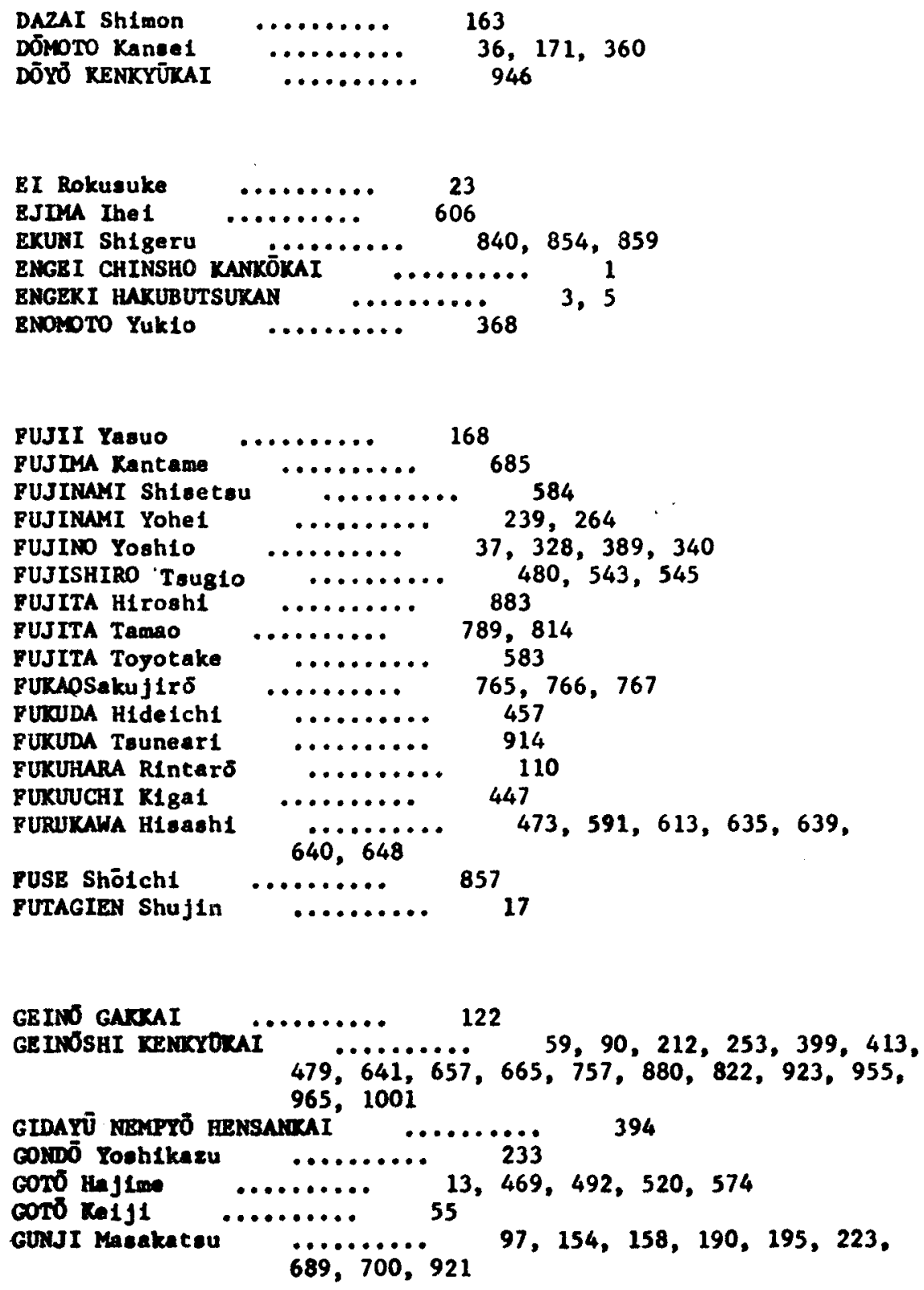


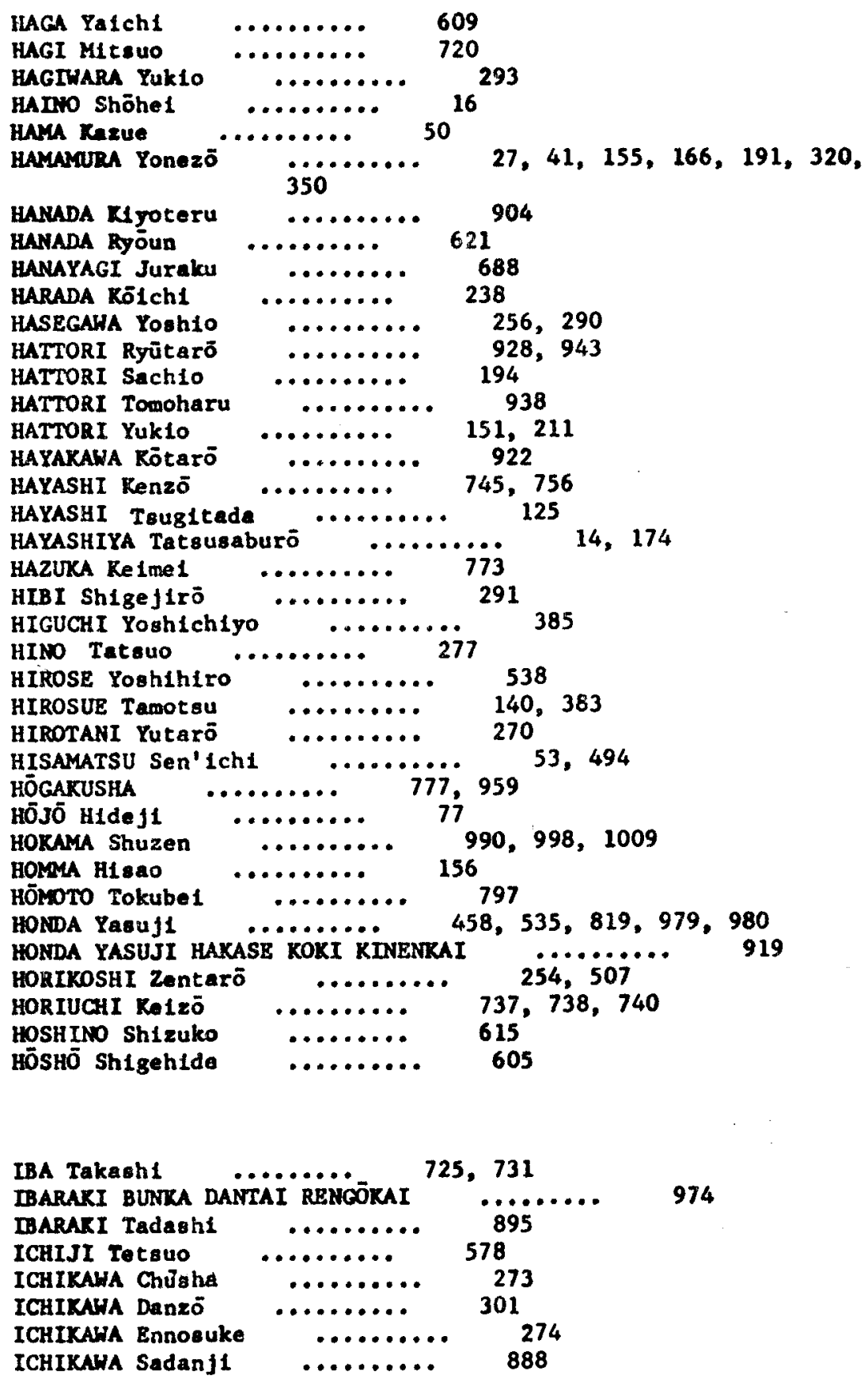




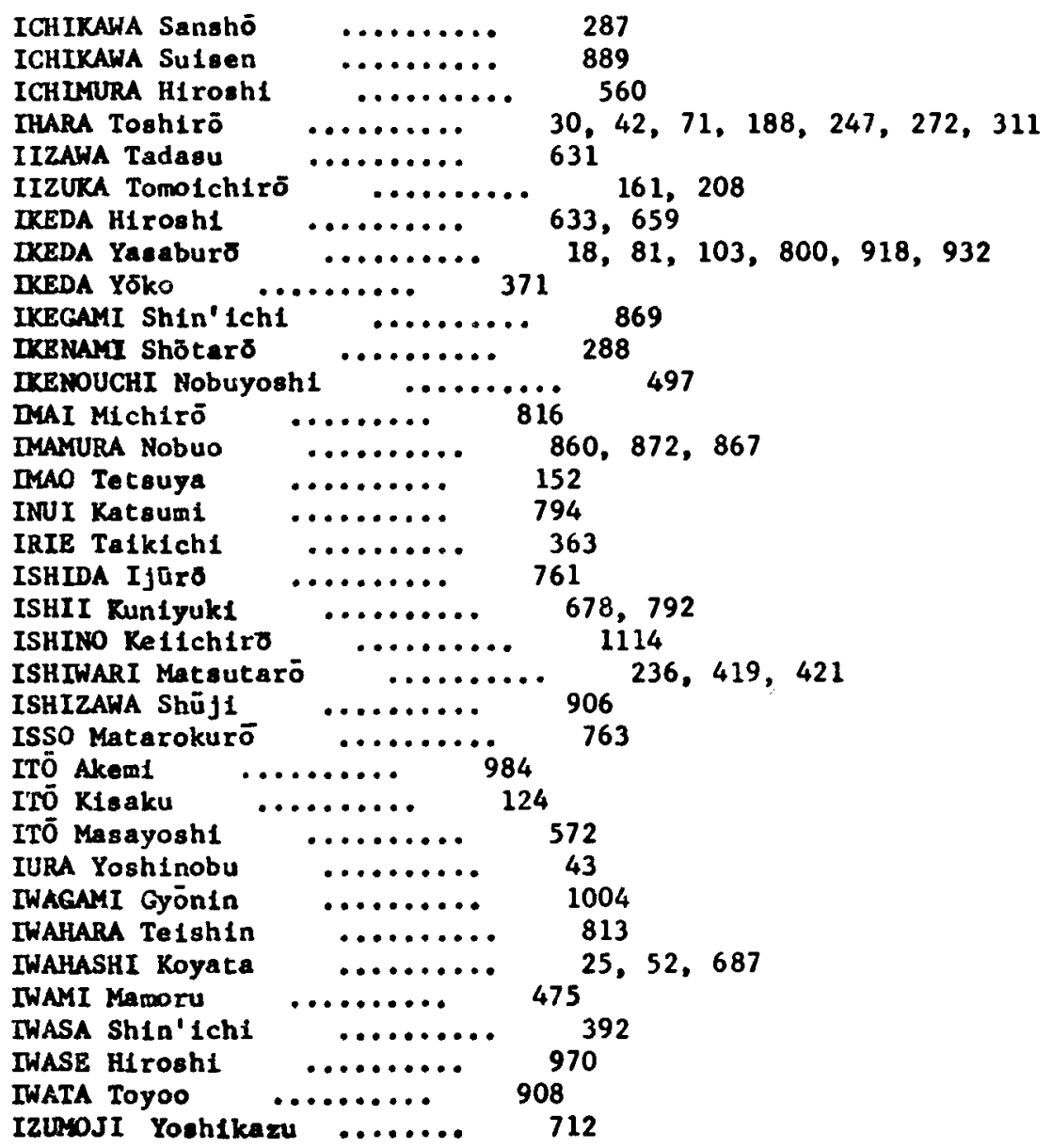




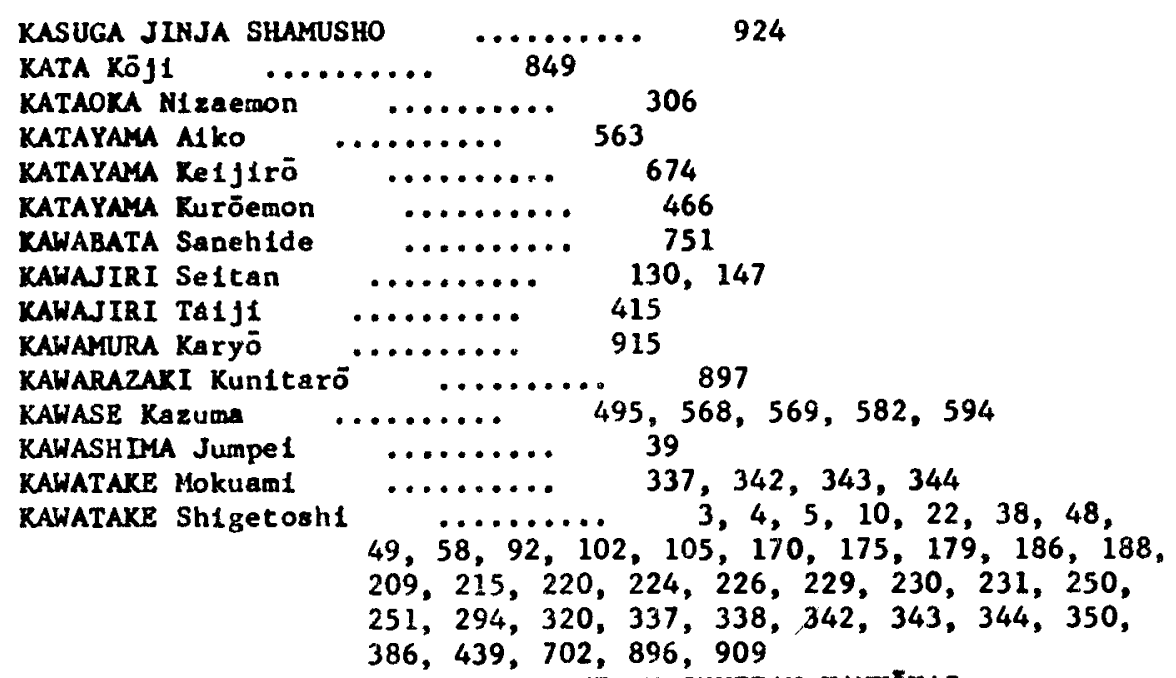

KAWATAKE SHIGETOSHI HAKASE KIJU KINEN SHUPPAN RANKסKAI

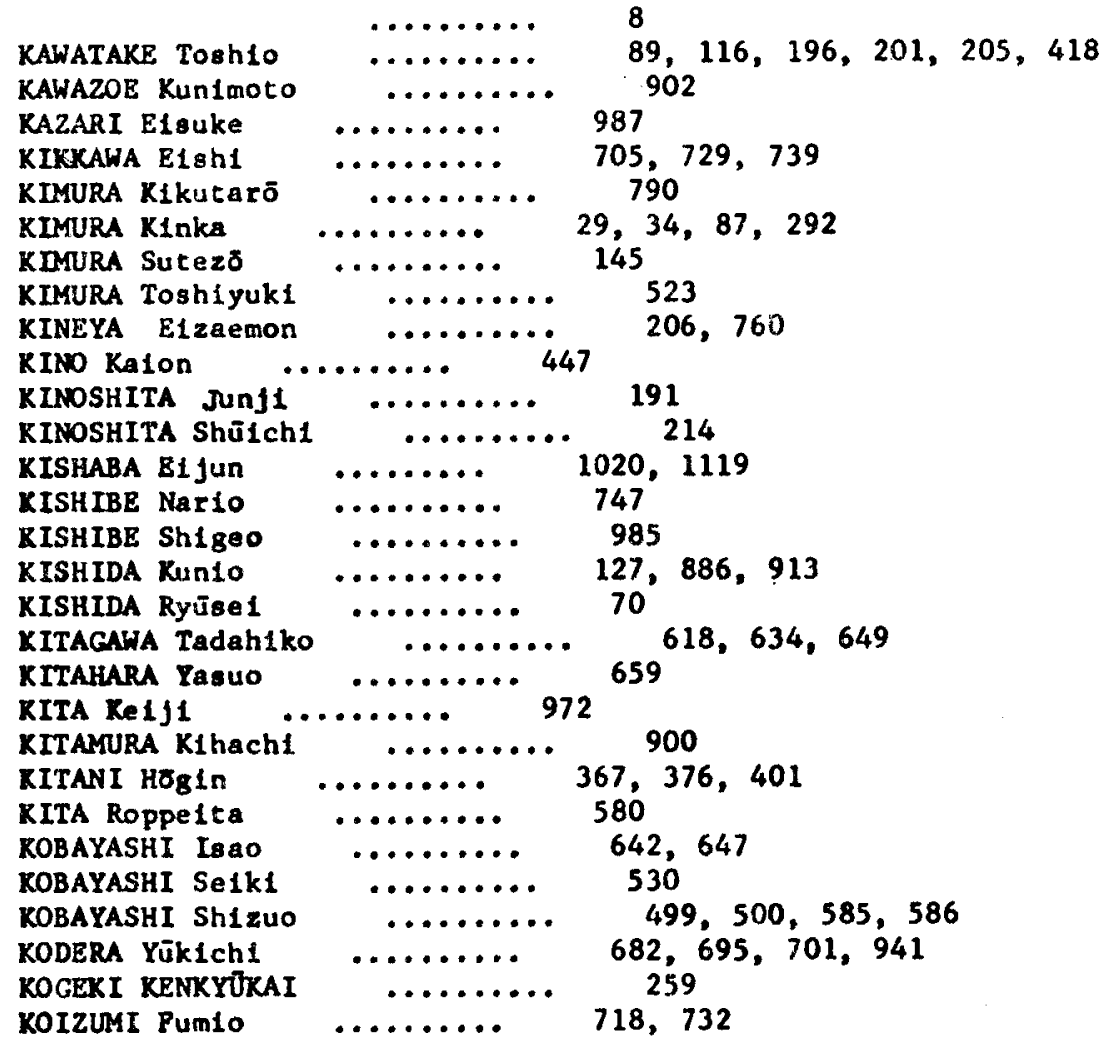




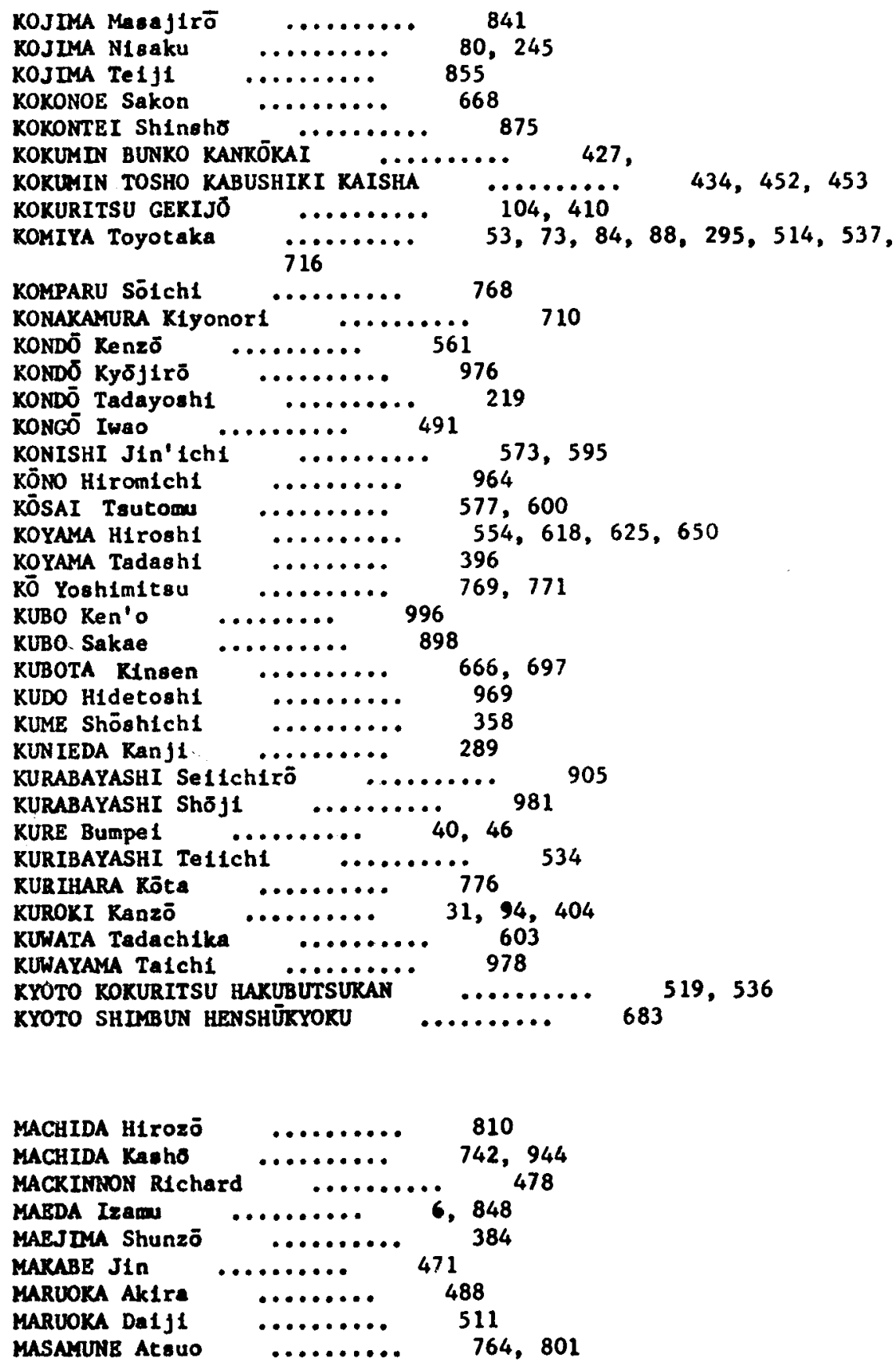




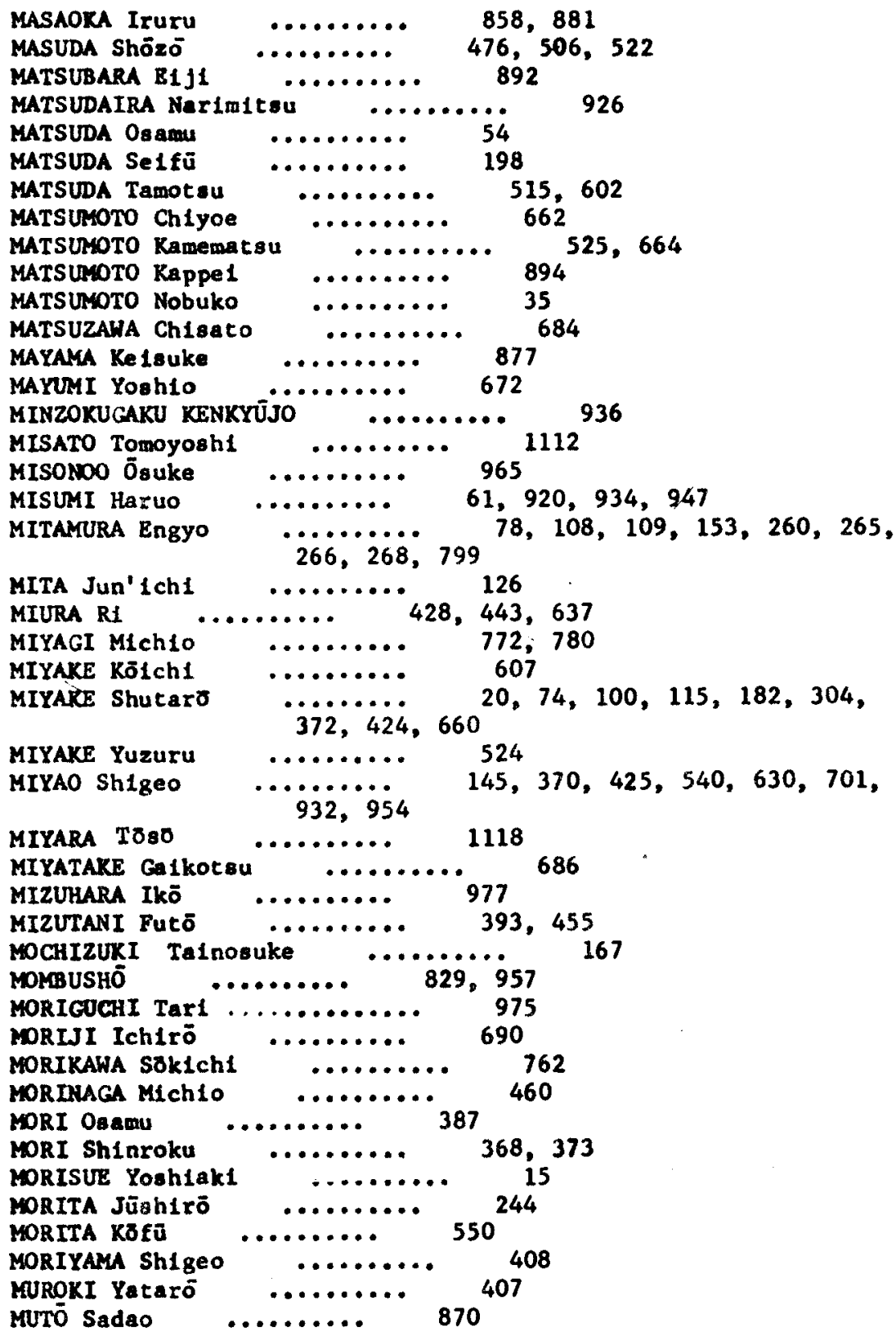




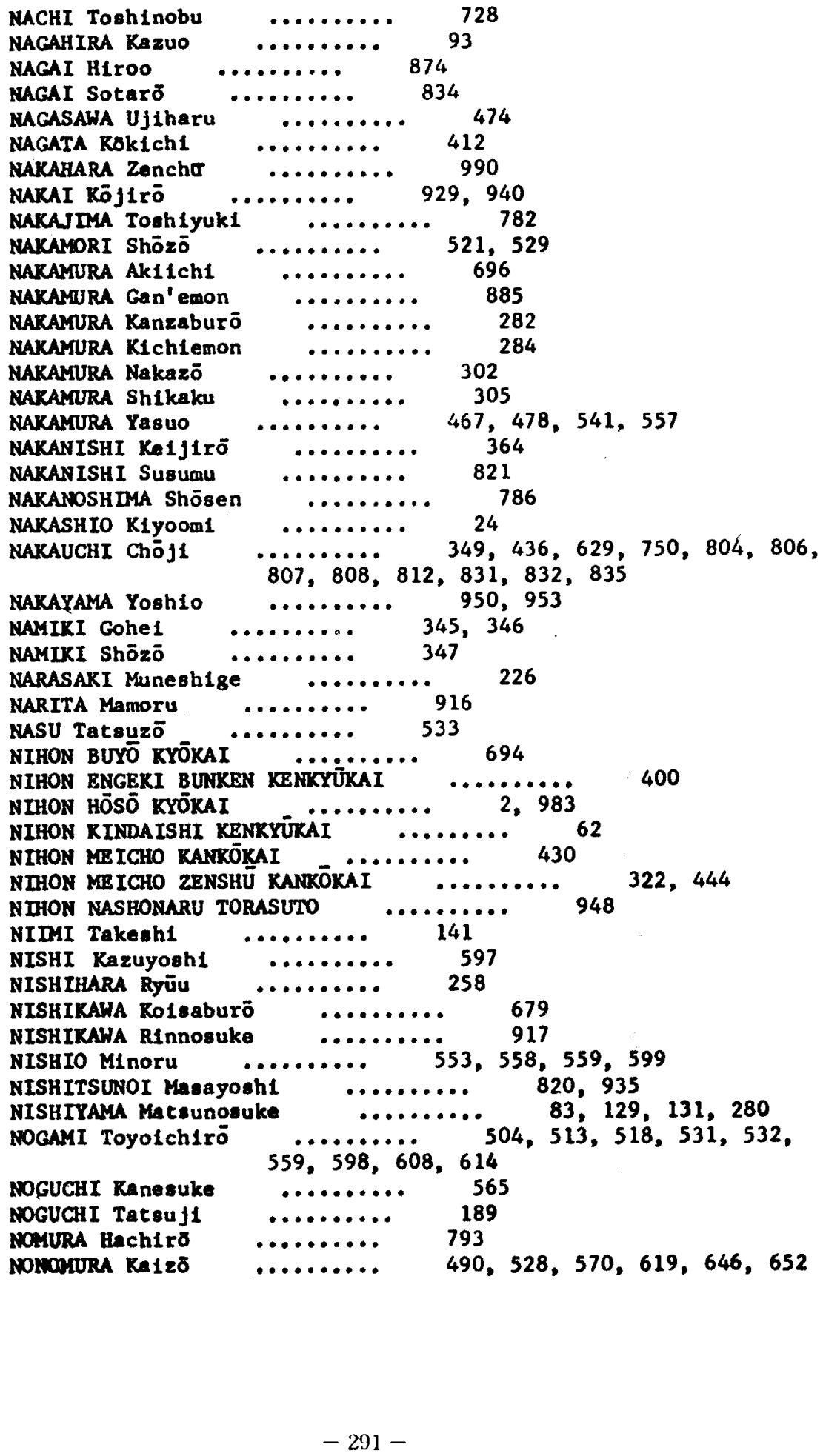




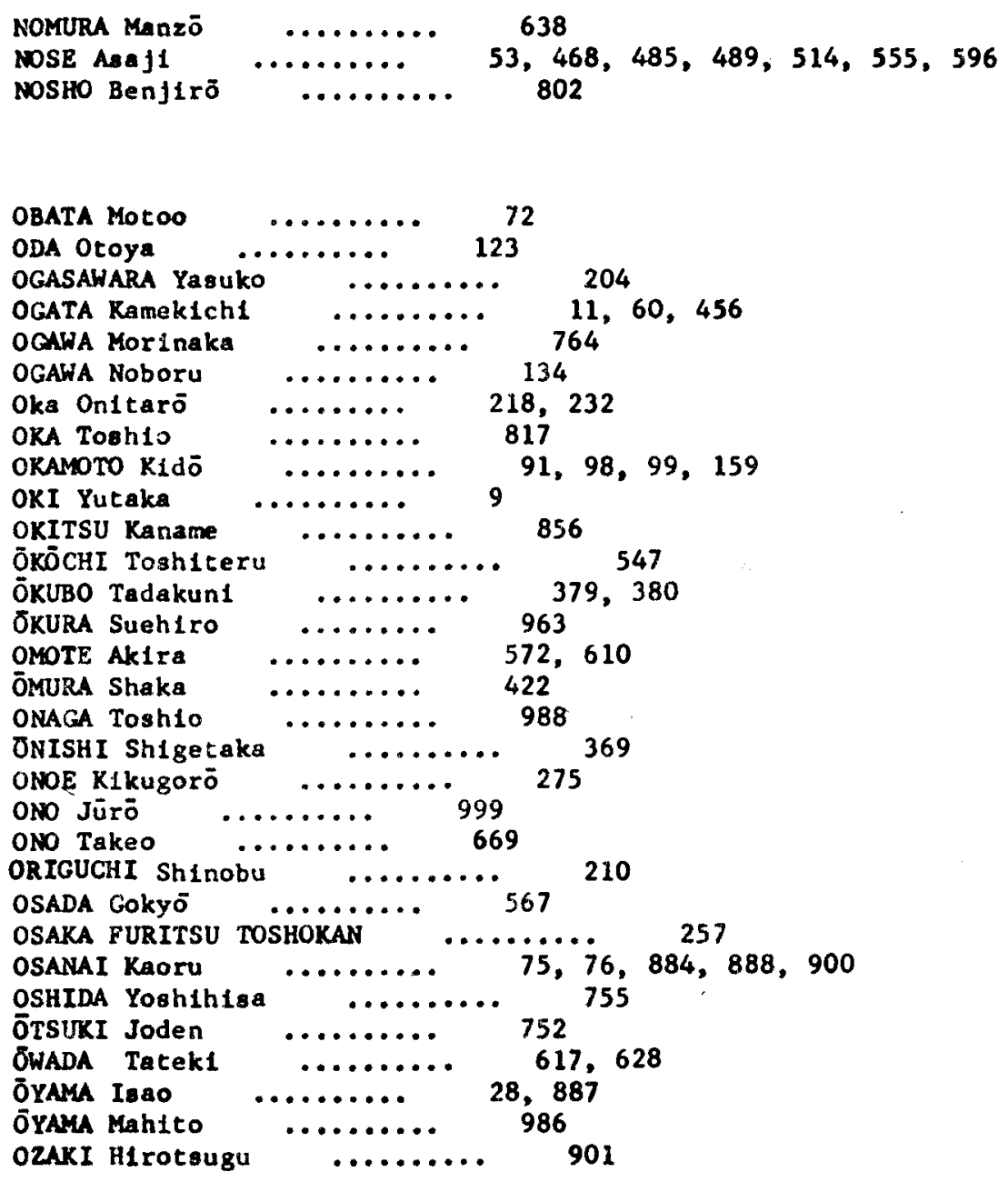

PERI Noe 1

RYŪKYŪ SHIRYO KENKYƯKXAI

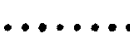

SAIGŌ Nobut Buna

SAIJŌ Yaso

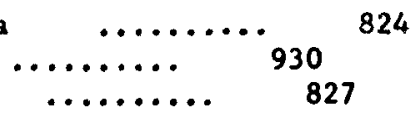

SAITŌ Gesahl ........ 827 


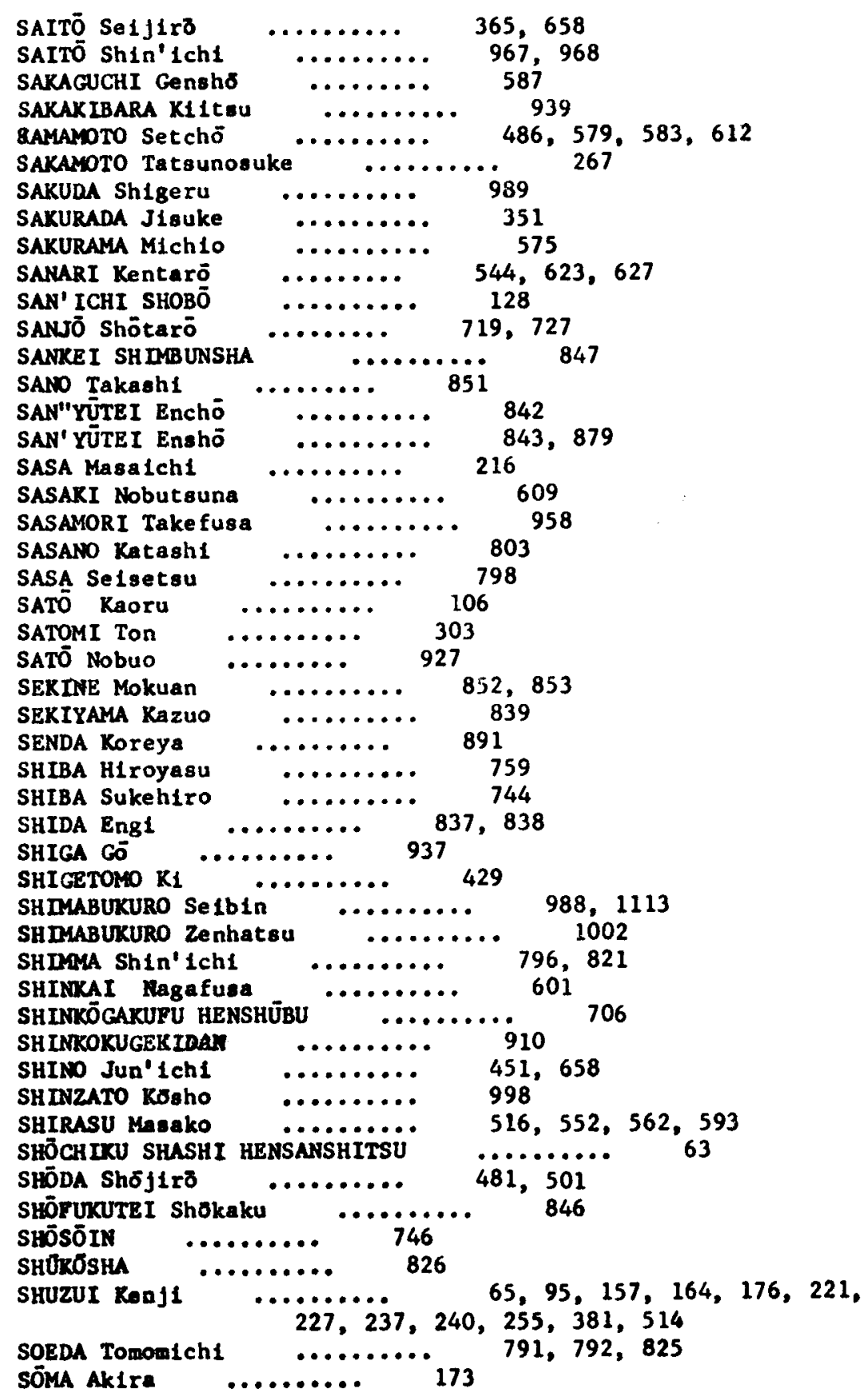




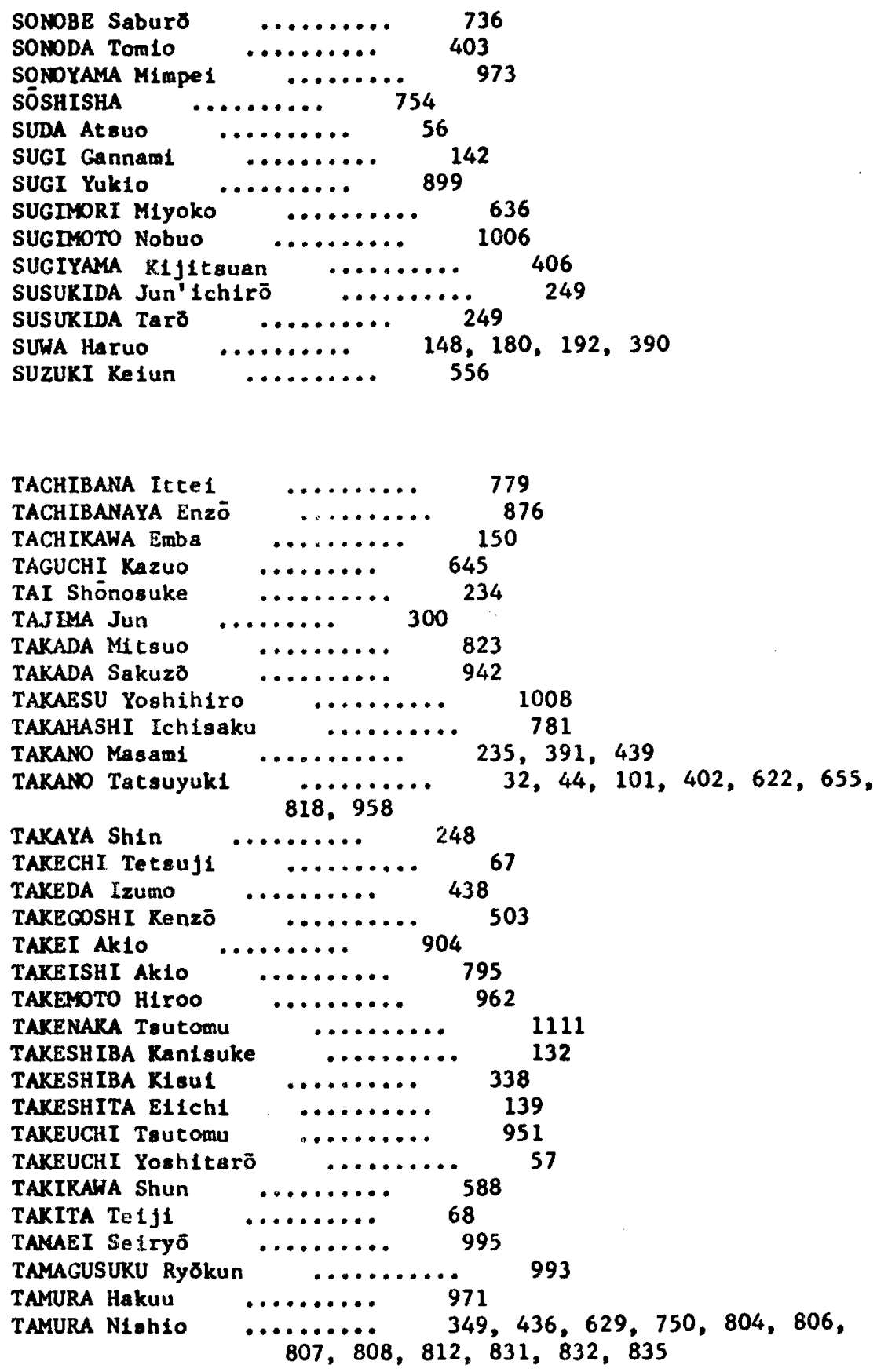




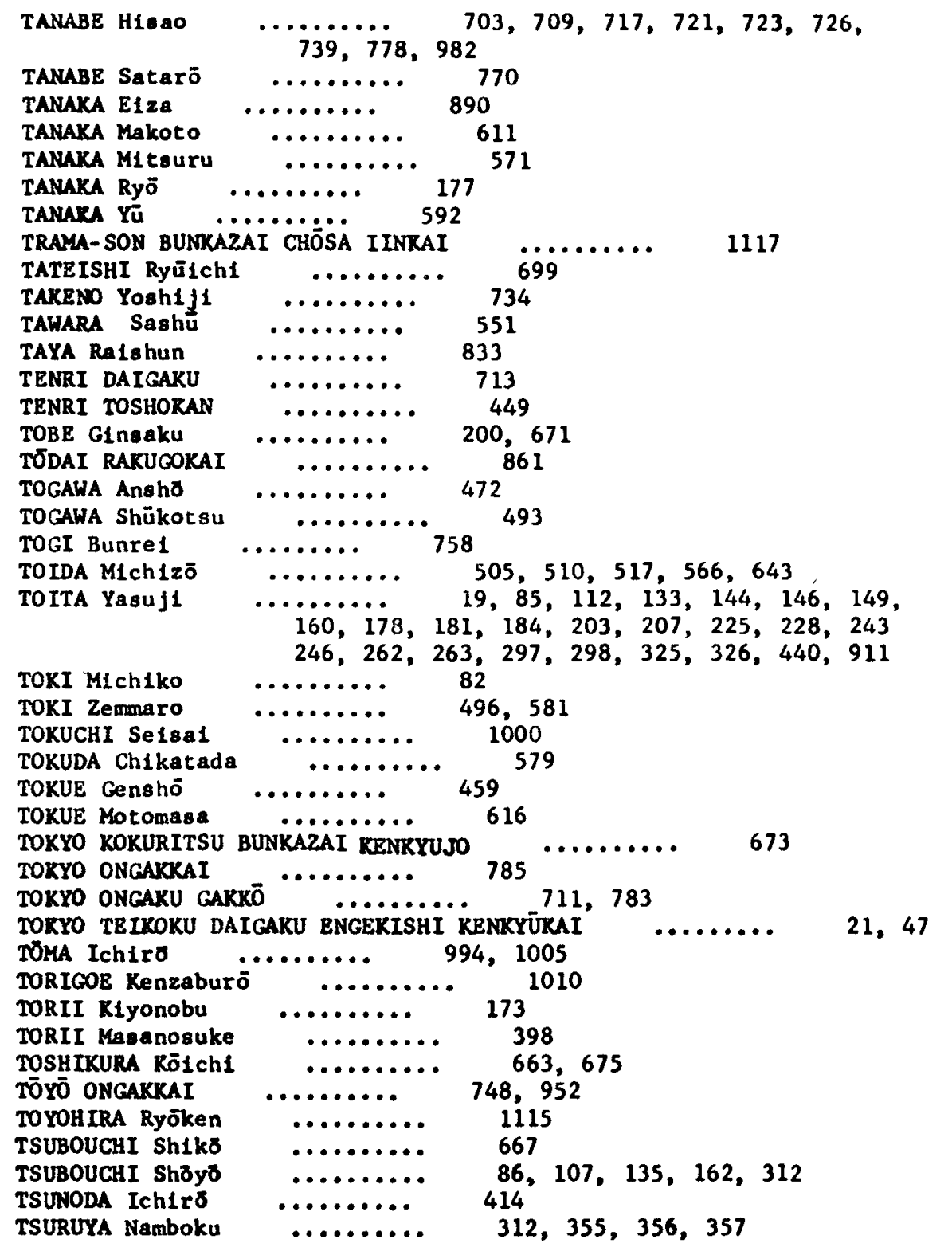

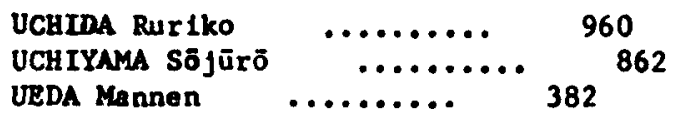




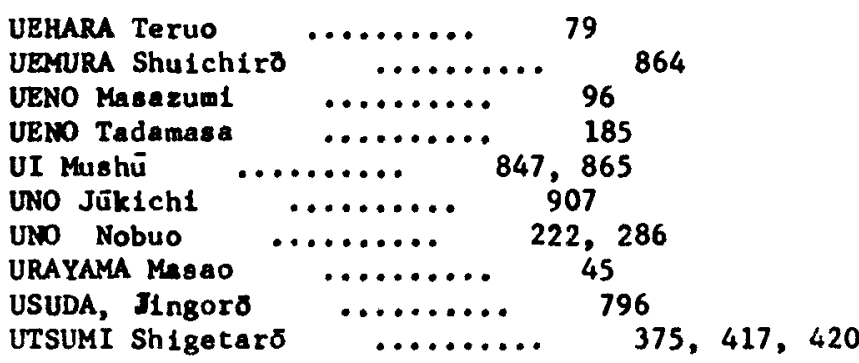

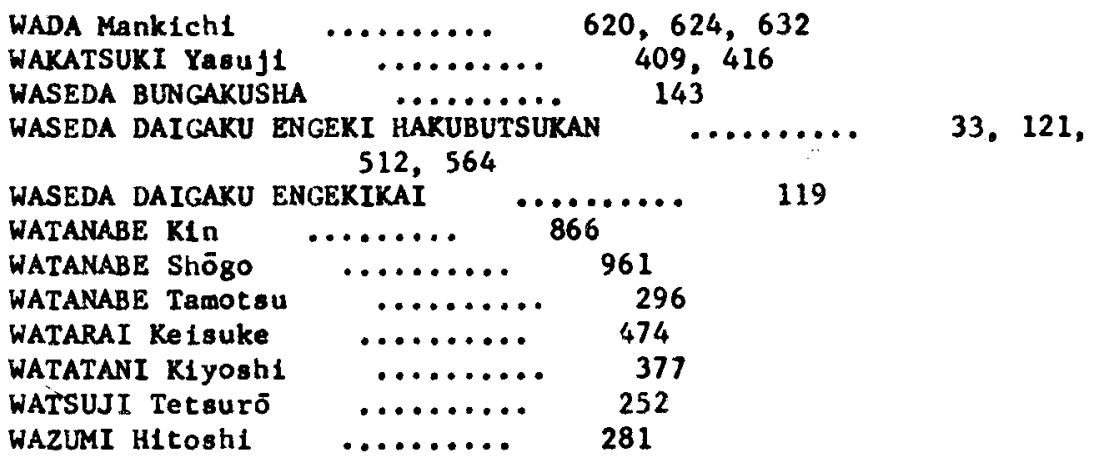

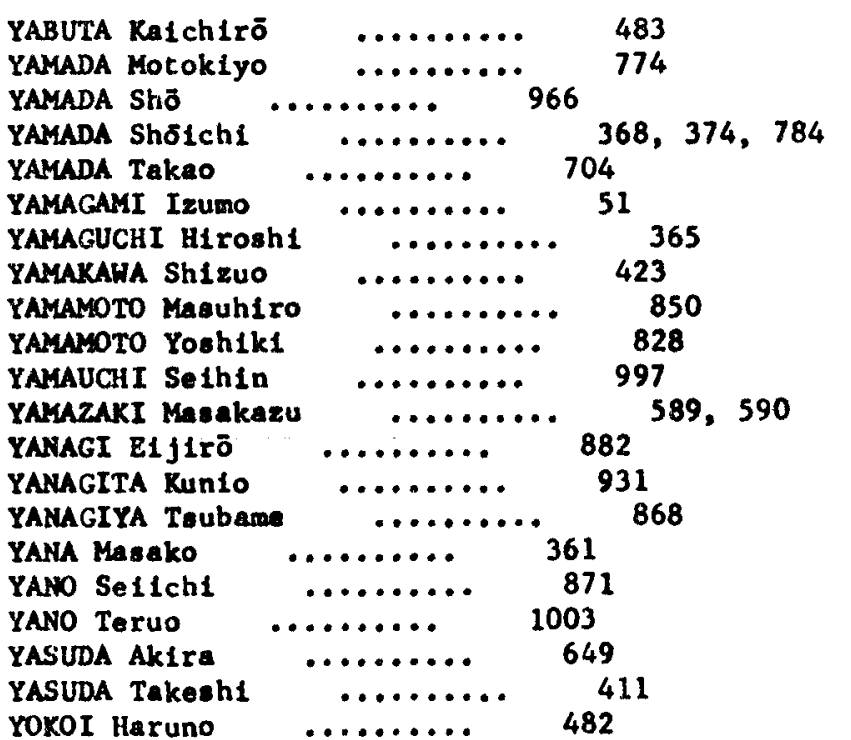




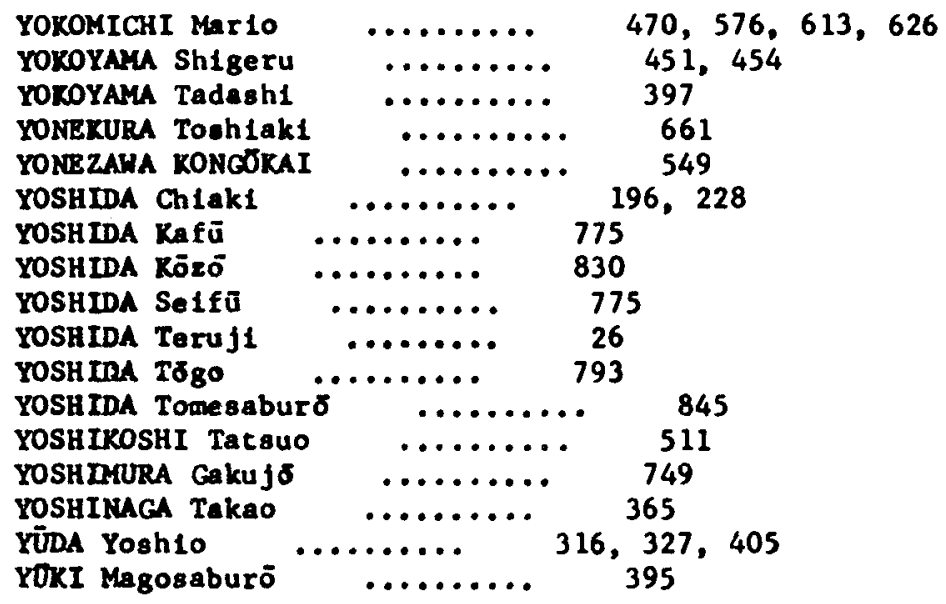

ZEAYI $\quad \ldots \ldots \ldots \ldots \quad 559,560,564,568,569,570,582$, $592,594,595,596$ 
TITLE INDEX
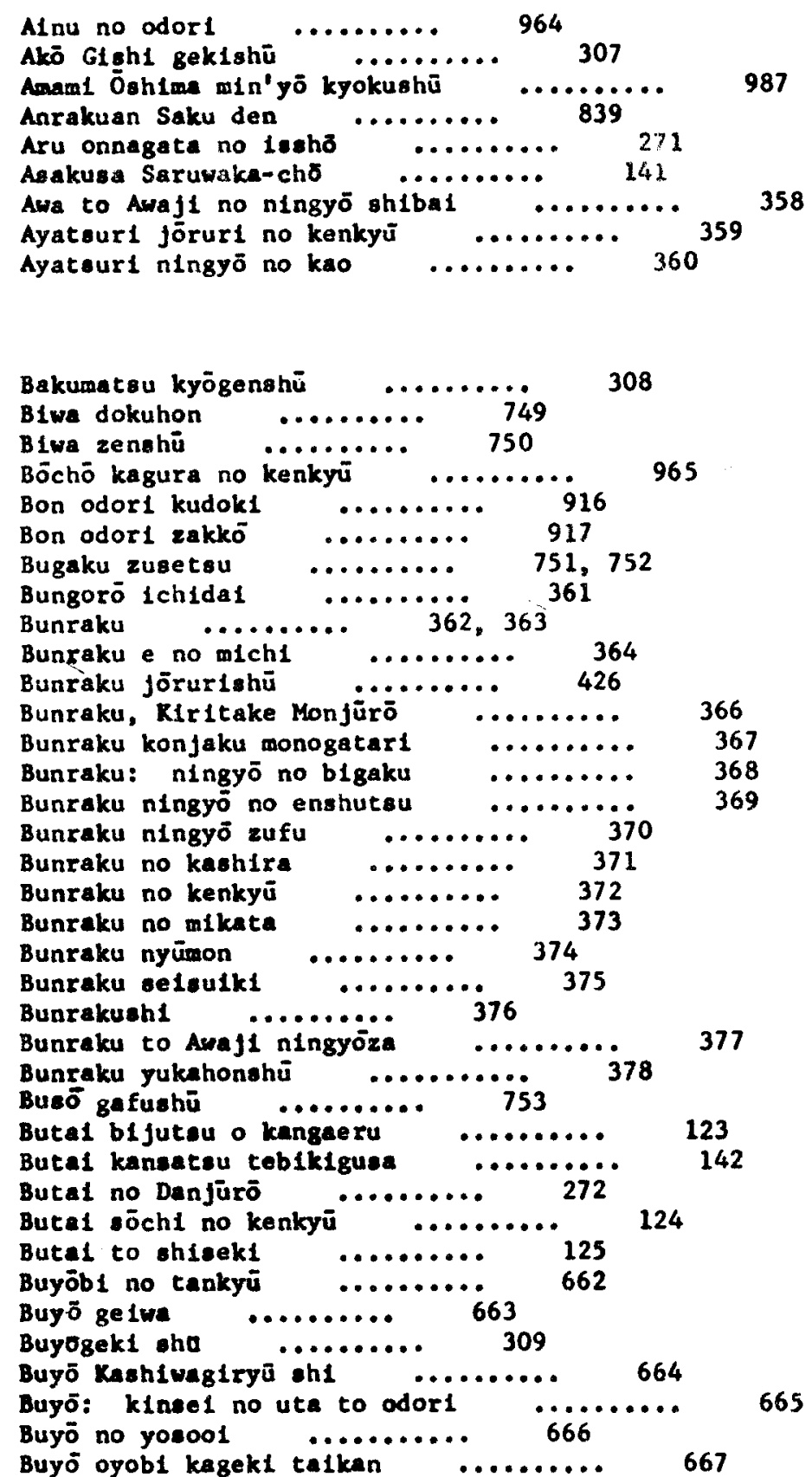


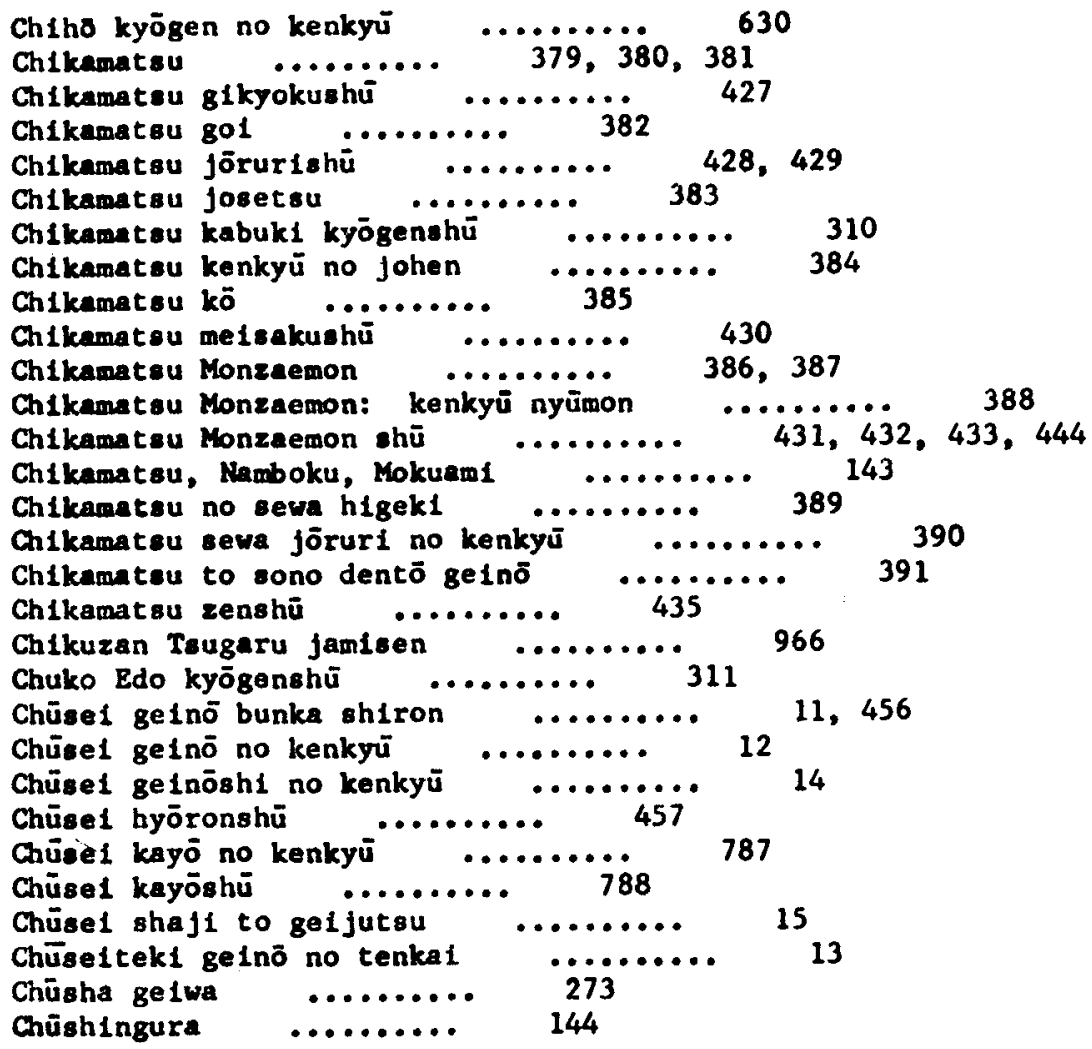

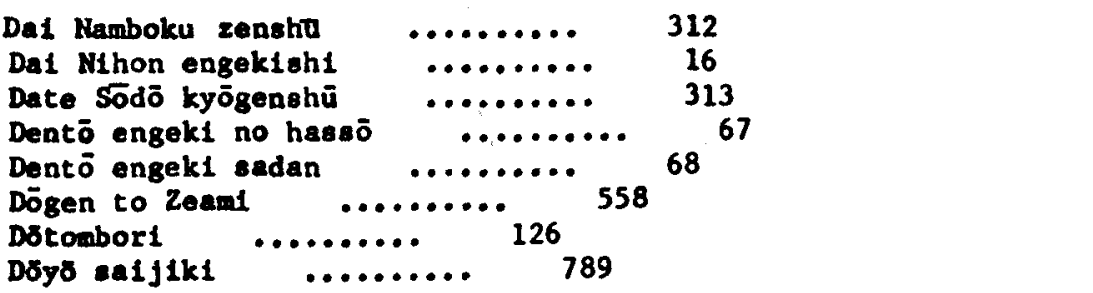

Bbanzuke, ShImpa gekidan $\quad \ldots \ldots \ldots \ldots . .682$

Ech1go goze nikk1 ......... 967

Edo Bungo jörurish1 ......... 392

Edo j1da1 gikyoku hōsetsu teüsh1 $\ldots \ldots \ldots \ldots . .17$

Bdo jida1 no geino $\ldots \ldots \ldots \ldots \ldots$ 18

Edo kabukt uchivae $\quad \ldots \ldots \ldots \ldots . .145$ 


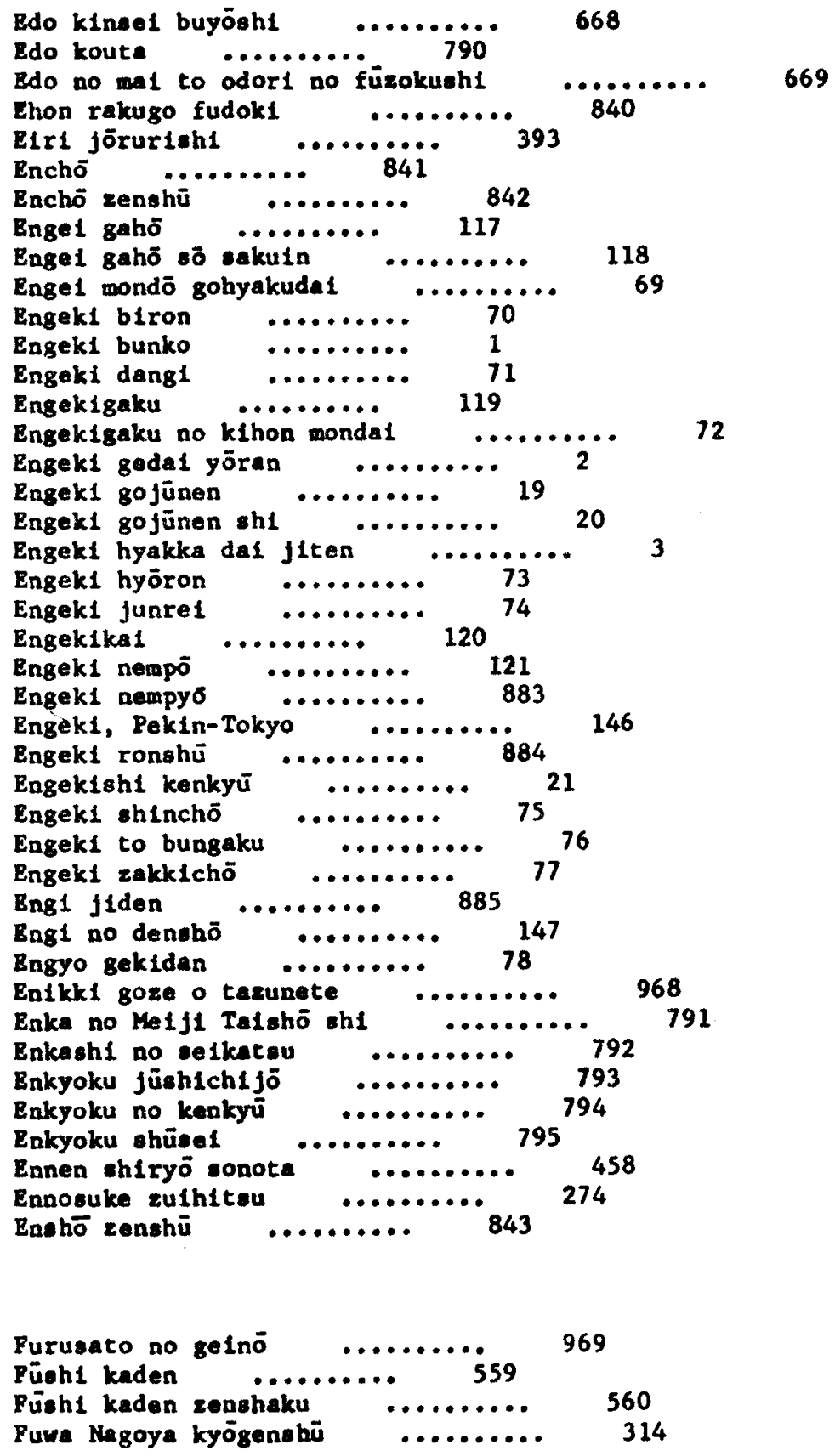

Puwa liagoya kyögenahü $\quad \ldots \ldots \ldots \ldots . . . \quad 314$ 


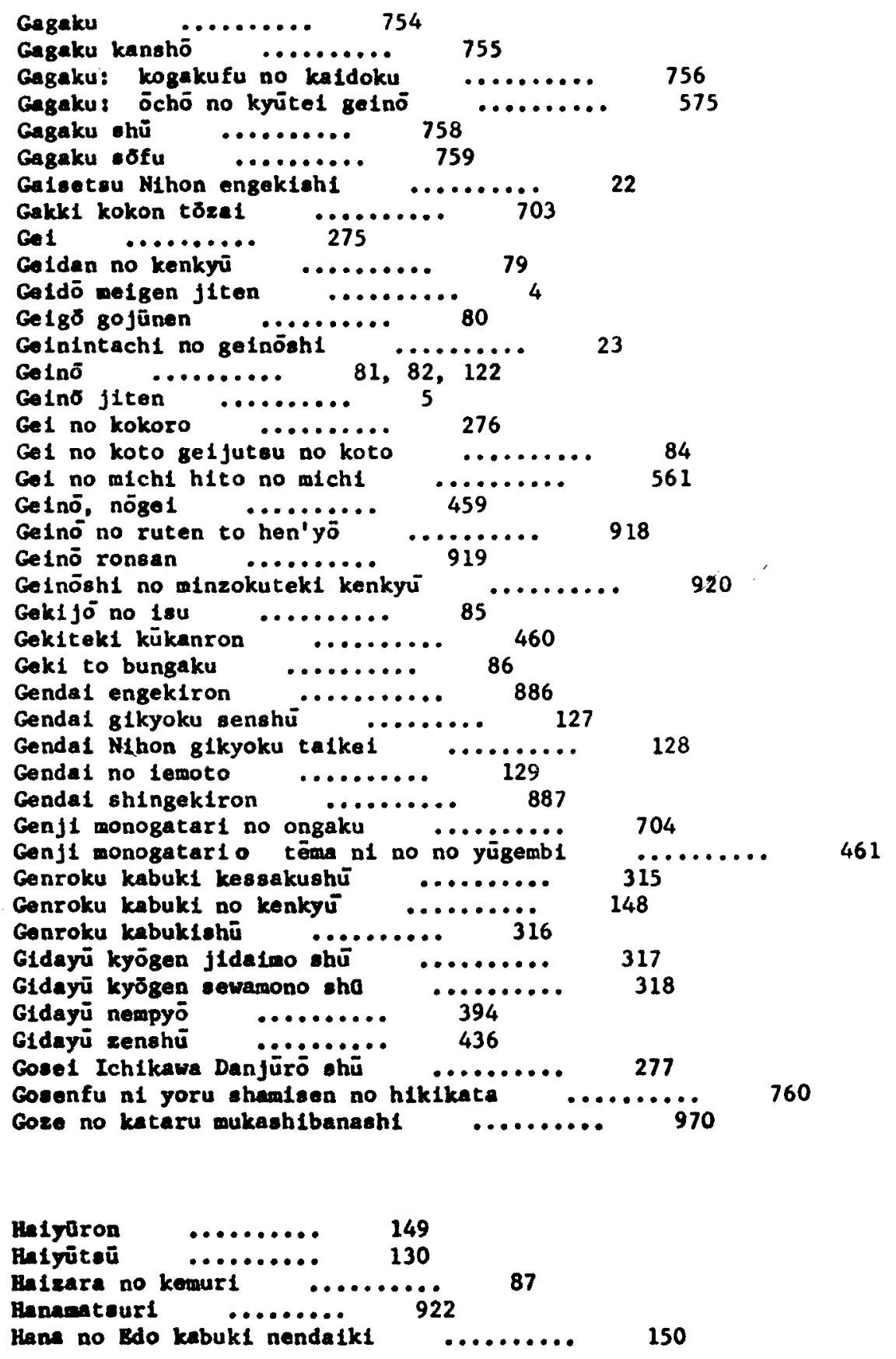




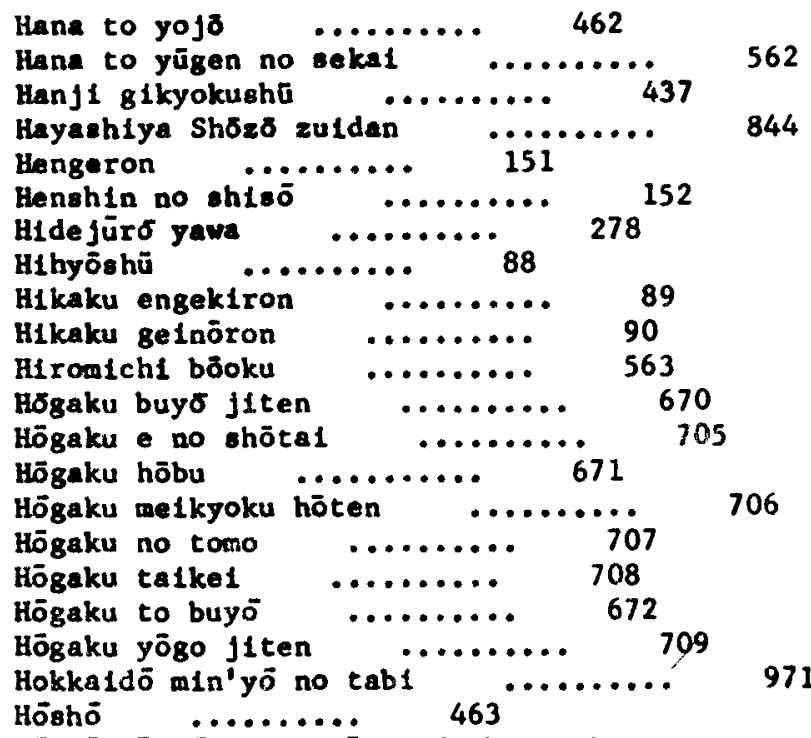

Höshö $\quad \cdots \ldots \ldots \ldots$...... 463

Hōshō shöhon: Shōwa-ban ......... 605

Hōshō shōhon Shöwa-ban ka1setsu $\ldots \ldots \ldots \ldots .606$

Hyōgo-ken minzoku geinöshı _........ 972

Hyōjun Nihon buyōshū ........ 673

Hyöon ghöshaku Ryaka zenshä ......... 988

Hyōshl seikal $\ldots \ldots \ldots \ldots$.... 607

Hyūga min'yō $\quad \ldots \ldots \ldots \ldots .973$

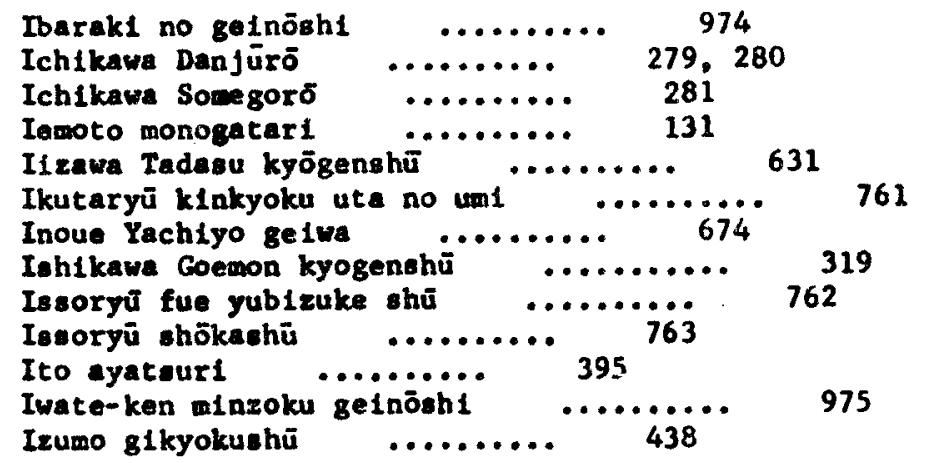

Jidal kyögen kessakuehū
Jiden yappar 1 yakusha .............. 


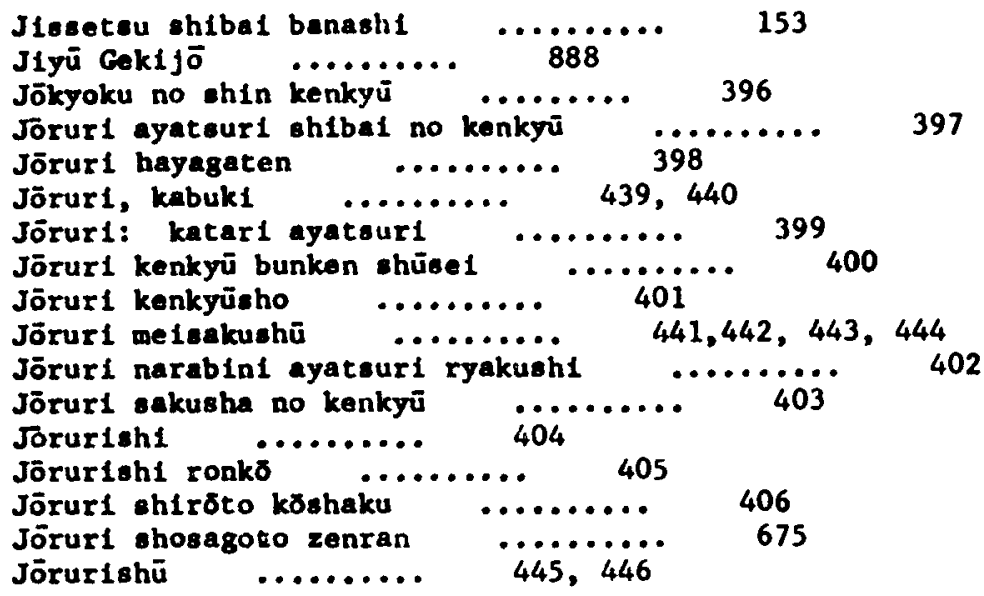

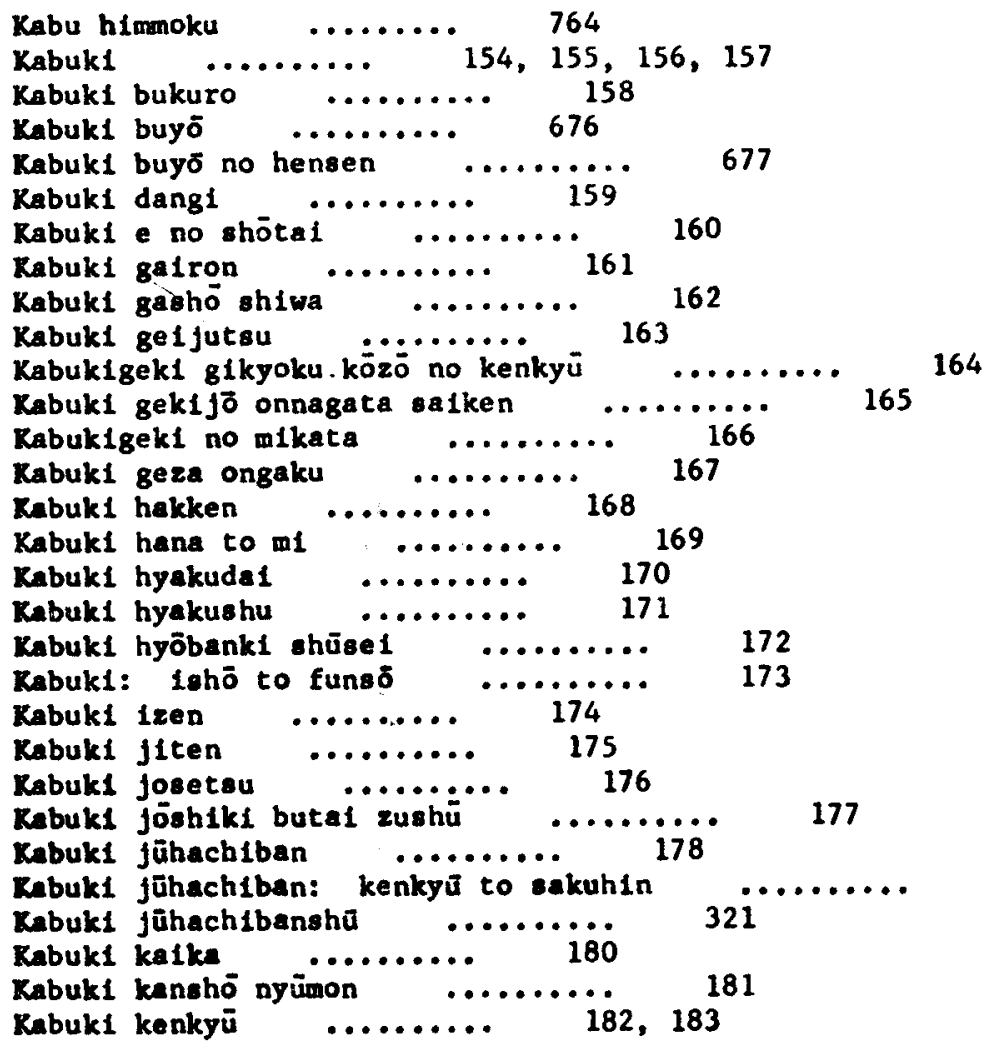




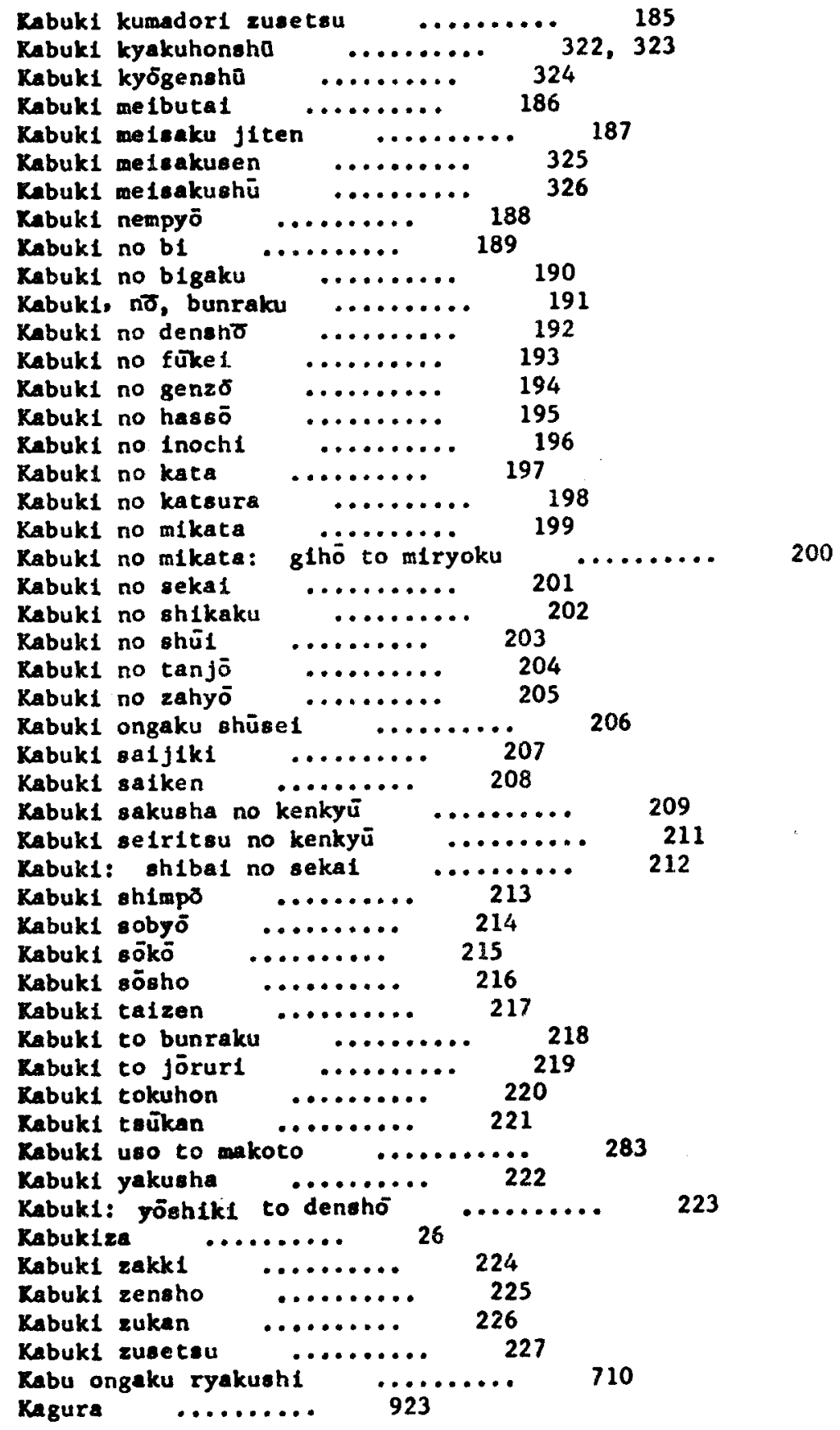


Kagurauta, ealbara, Ryōjin hishō, Kanginahū

Kaichū nagauta nihyakuban

Kåchū yōkyolku zenshū

Ka Ion Bunkōdö K1ga1 gikyokushū

..........

797

(..........

796

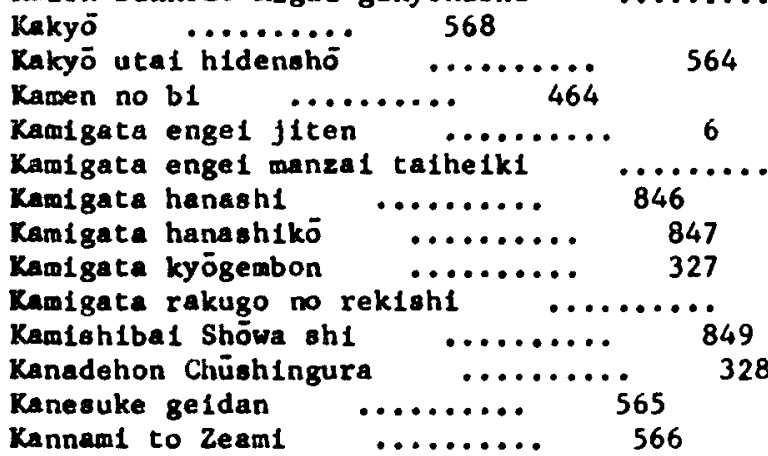

Kansei-ki Edo sewa kyögenshü ........ 329

Kange1-ki Keihan adauch1 kyōgenshü $\ldots \ldots \ldots \ldots .330$

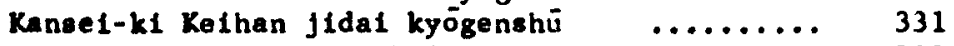

Kansel-k1 Kelhan sewa kyögenshū $\ldots \ldots \ldots \ldots . \quad 332$

Kantelryū kyöhon

........ 132 Kanze

Kanze-ke denra1 nōmenshū

Kaomise kyōgenshū

........ 333

Karä kabuk1 no miryoku

.........

Karä nö no miryoku

Kará Okinawa no uta to adori

$\ldots \ldots$

Kasef-do Edo adauchi kyōgenshü

467

466

228

Kasei-do Keihan adauch1 kyōgenshū

Kase1-do Edo sewa kyōgenshü

989

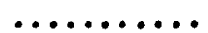

$\ldots \ldots \ldots \ldots+\cdots$

Kasuga Ömlya Wakamiya gosalreizu

...........

Katar Imono (ma1, sekkyō, kojōrurl) no kenkyūi 924

Katō $\quad \ldots \ldots \ldots \ldots$..... 798

Katsura Bunraku no seksi $1 . \ldots \ldots \ldots$... 850

Kawaraban no hayeriuta $\quad \ldots \ldots \ldots \ldots \ldots . . .799$

Kawatake Mokuani $\ldots \ldots \ldots \ldots .229,230,231$

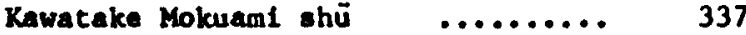

Kawateke Shinshichl oyobi Takeshiba Kisul shï ....... 338

Rayo $\quad \ldots \ldots \ldots \ldots . . .600$

Kayōahū $\quad \ldots \ldots \ldots \ldots . . .801$

Kente1 shōgaku shoke _........ 802

Klchlemon nikki $\ldots \ldots \ldots \ldots . .284$

Kichlemon no kalso $\quad \ldots \ldots \ldots \ldots . . \ldots 28$

Kidó gekidan $\ldots \ldots \ldots \ldots . .999$

Kigen jogo $\quad \ldots \ldots \ldots \ldots \ldots$.

Kikugoro yawa $\ldots \ldots \ldots \ldots . .286$

Kimplrabon zenshū $\quad \ldots \ldots \ldots \ldots \ldots \quad 448$

Kindal gekibungaku $\quad \ldots \ldots \ldots \ldots . . . \% 92$ 


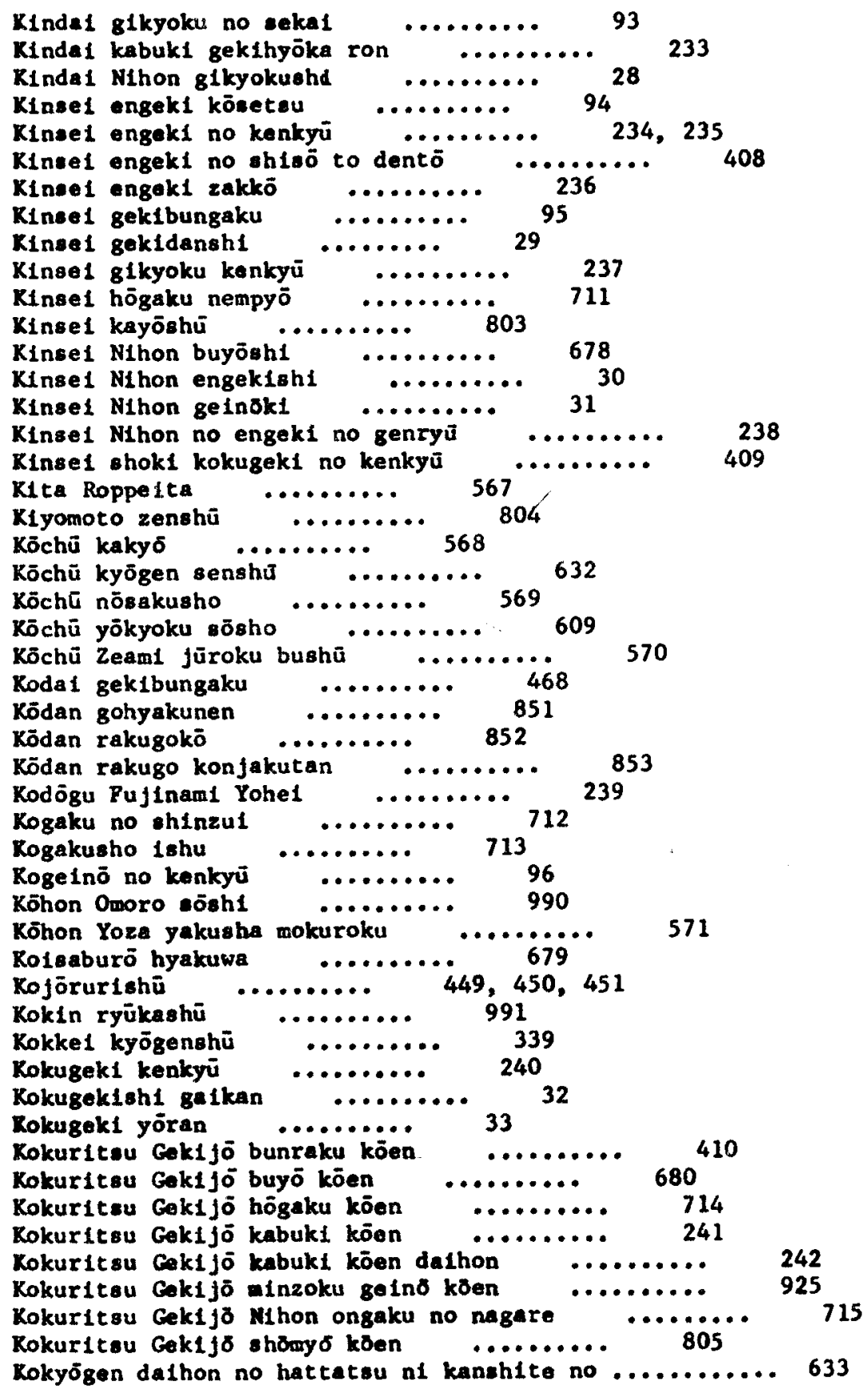




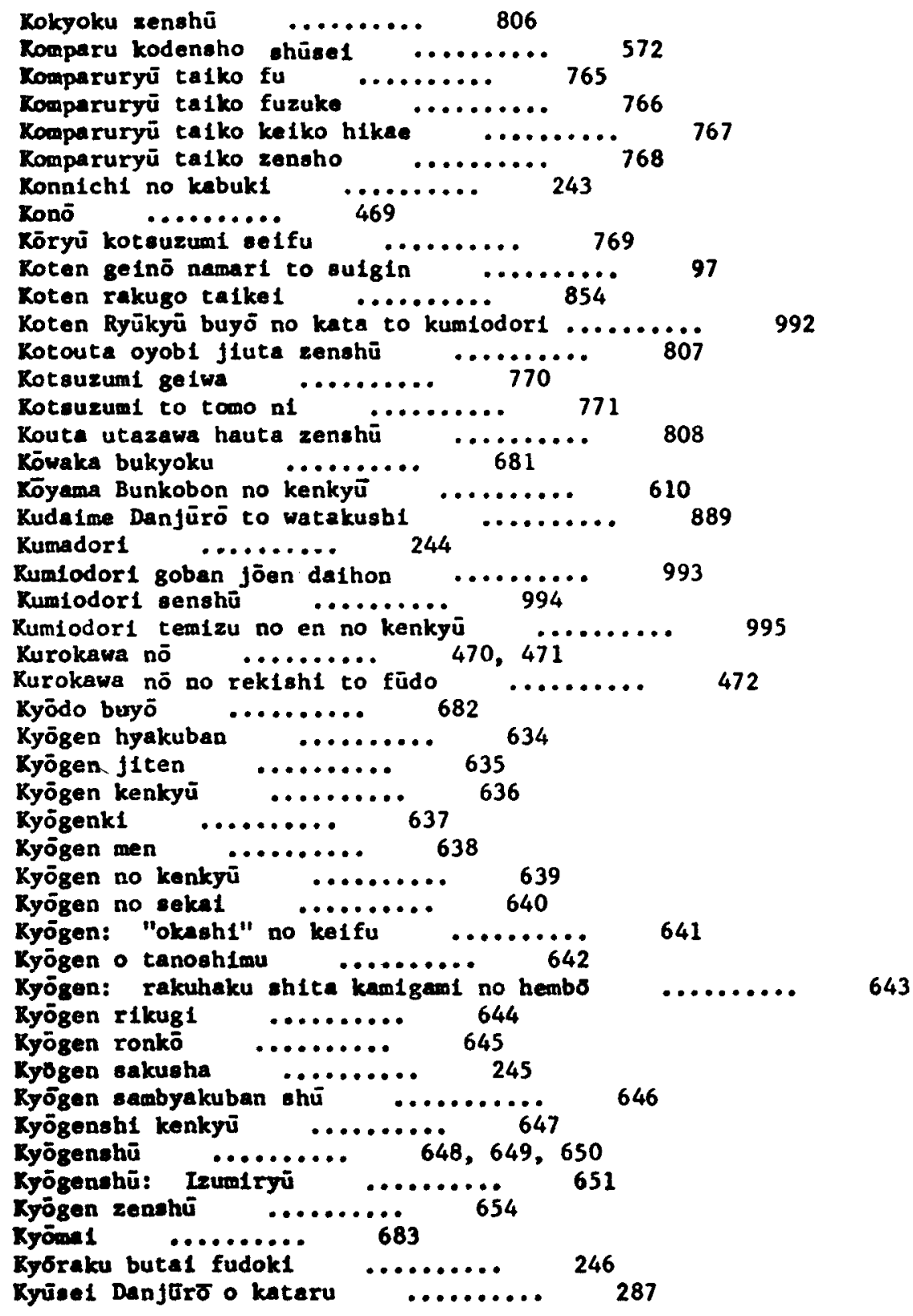




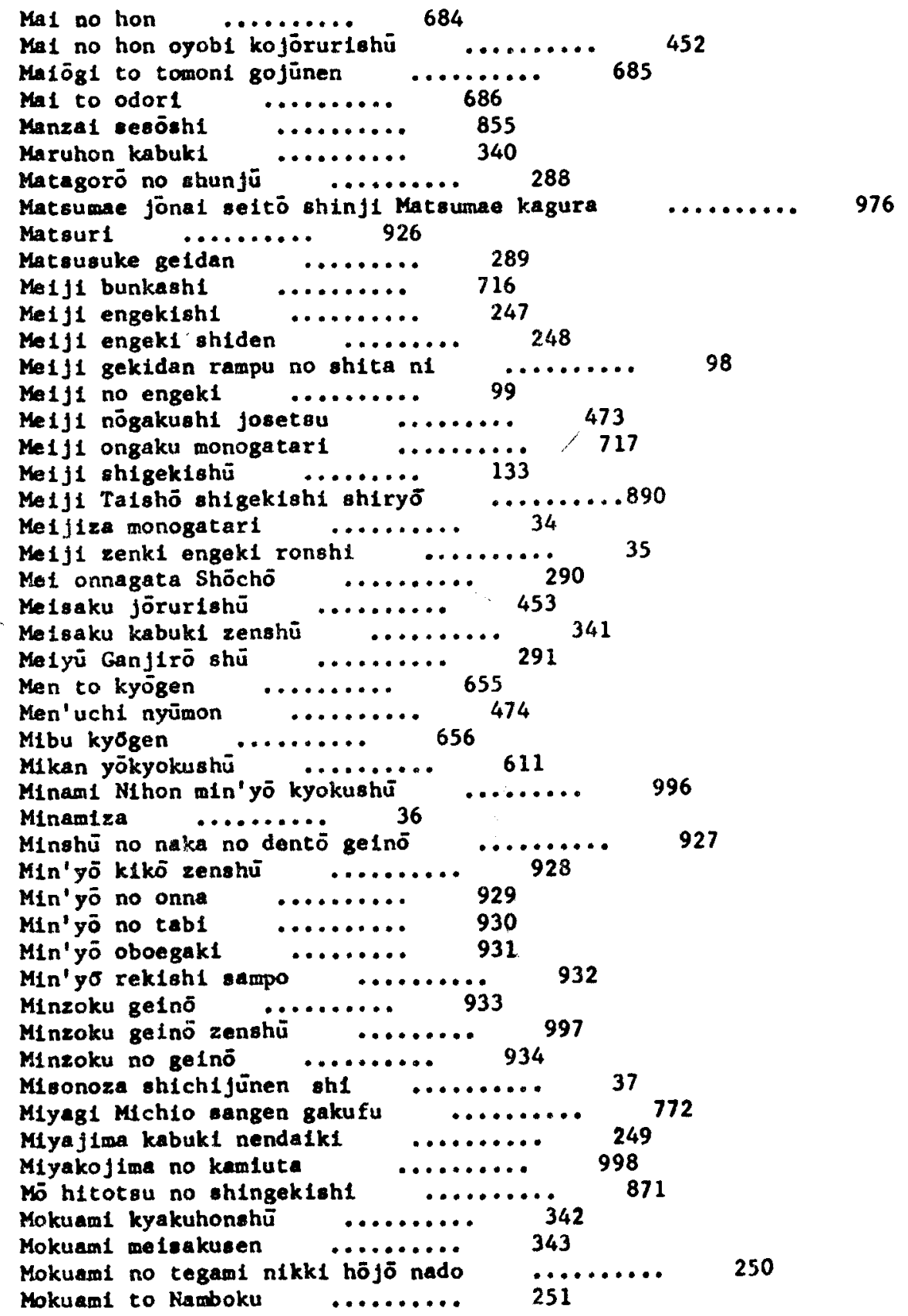




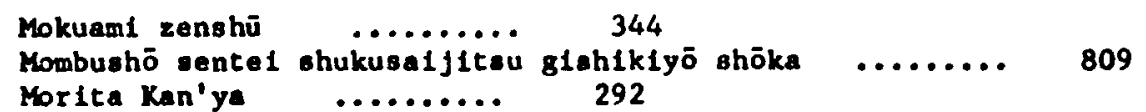

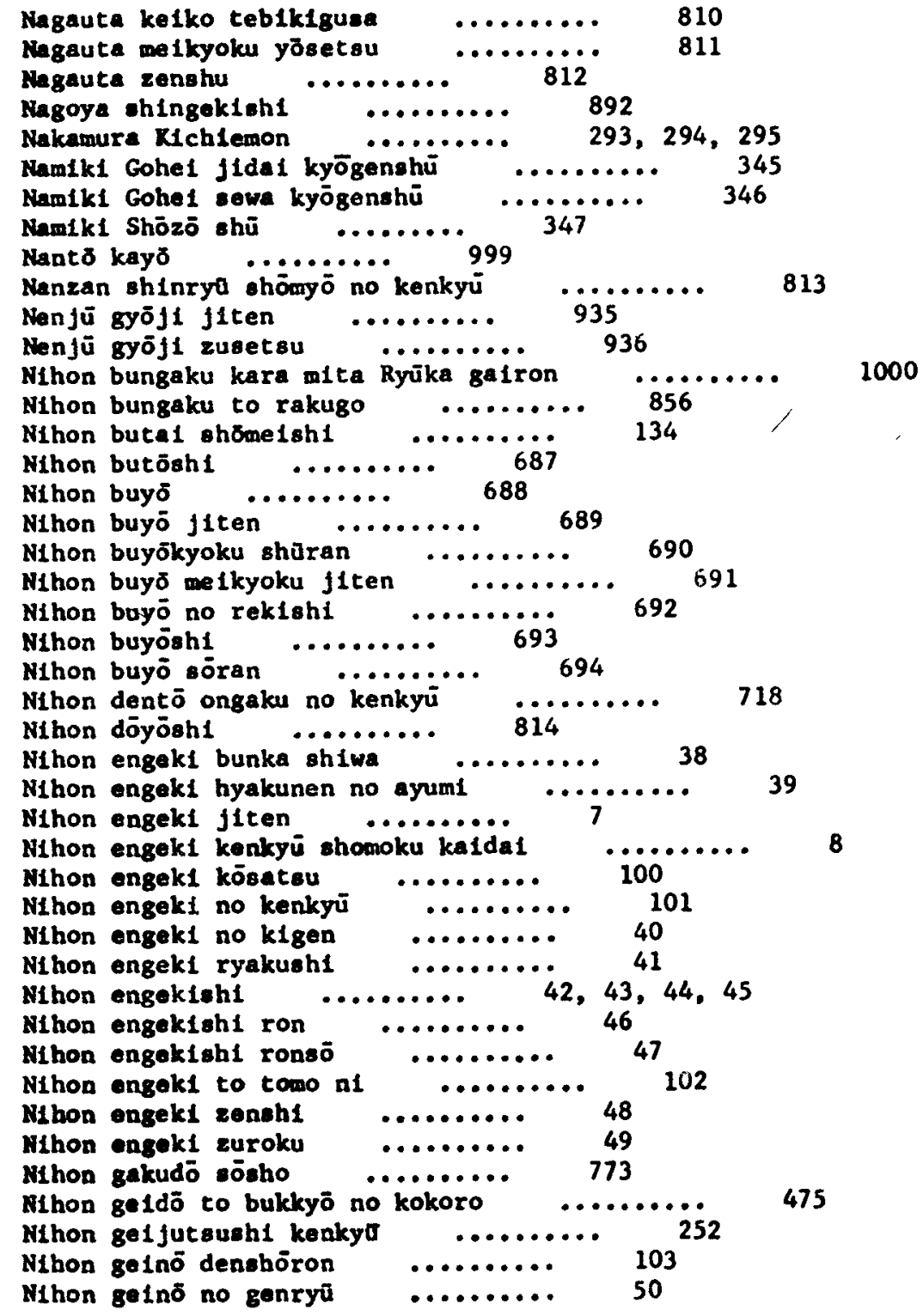




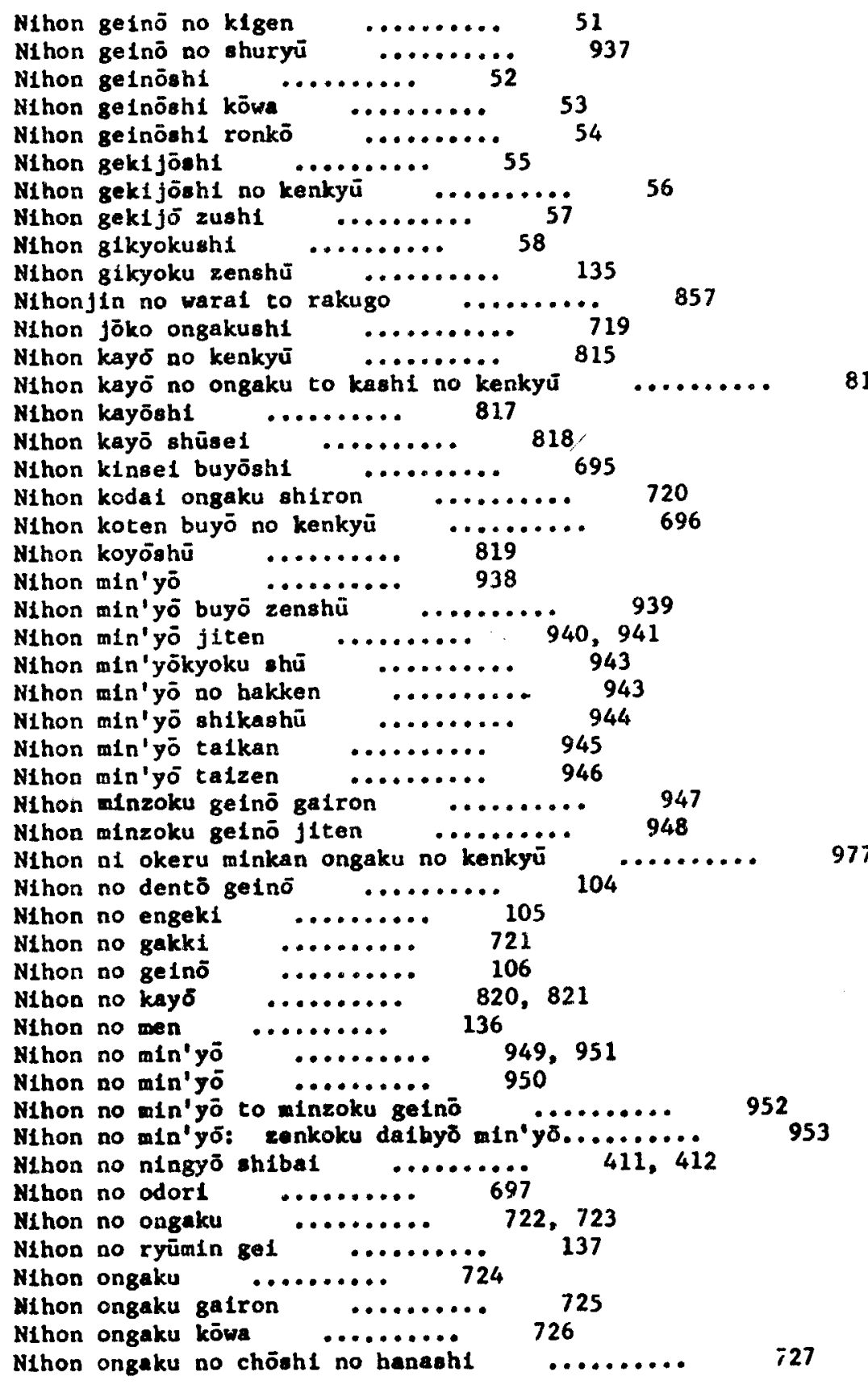




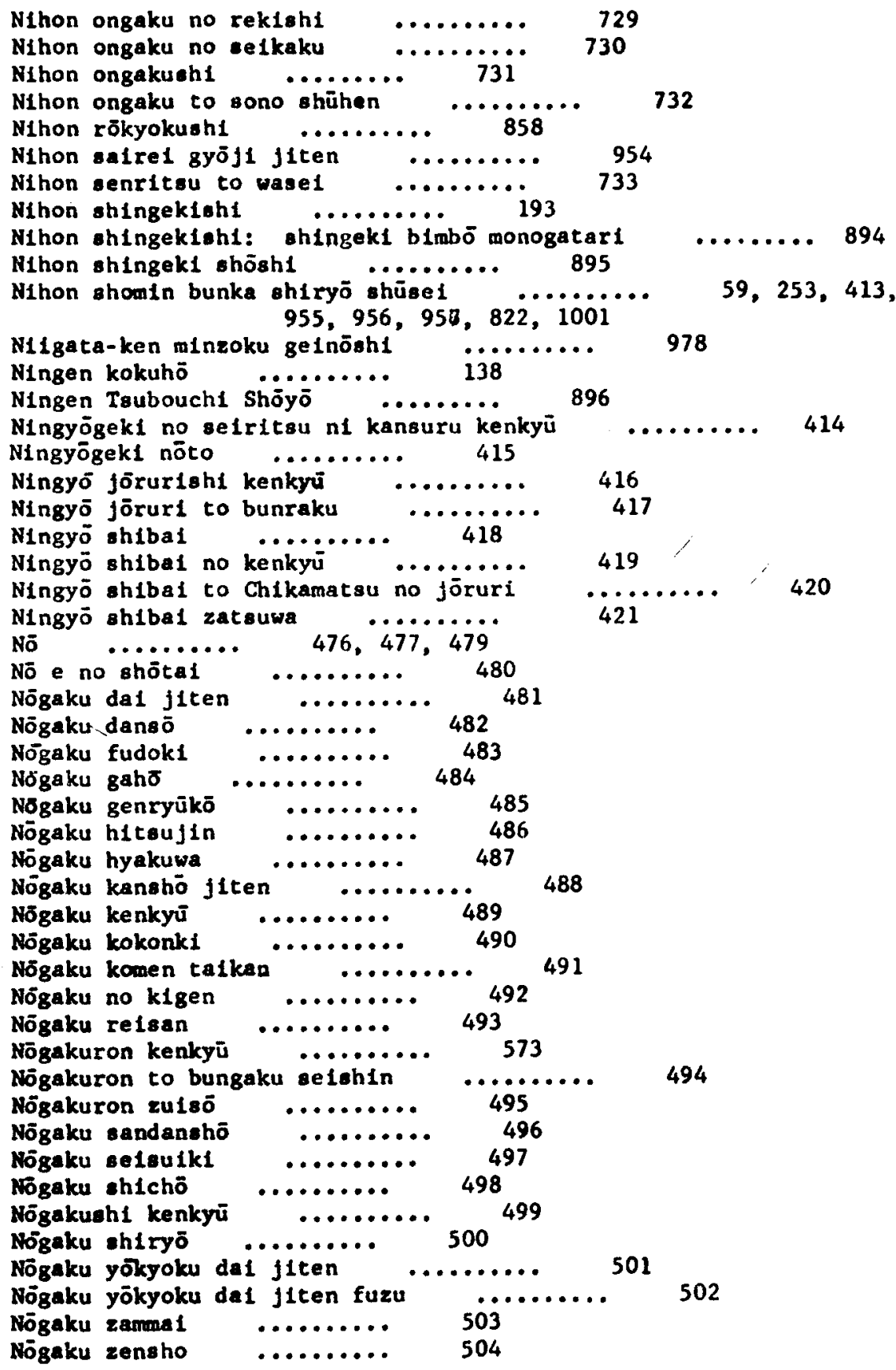




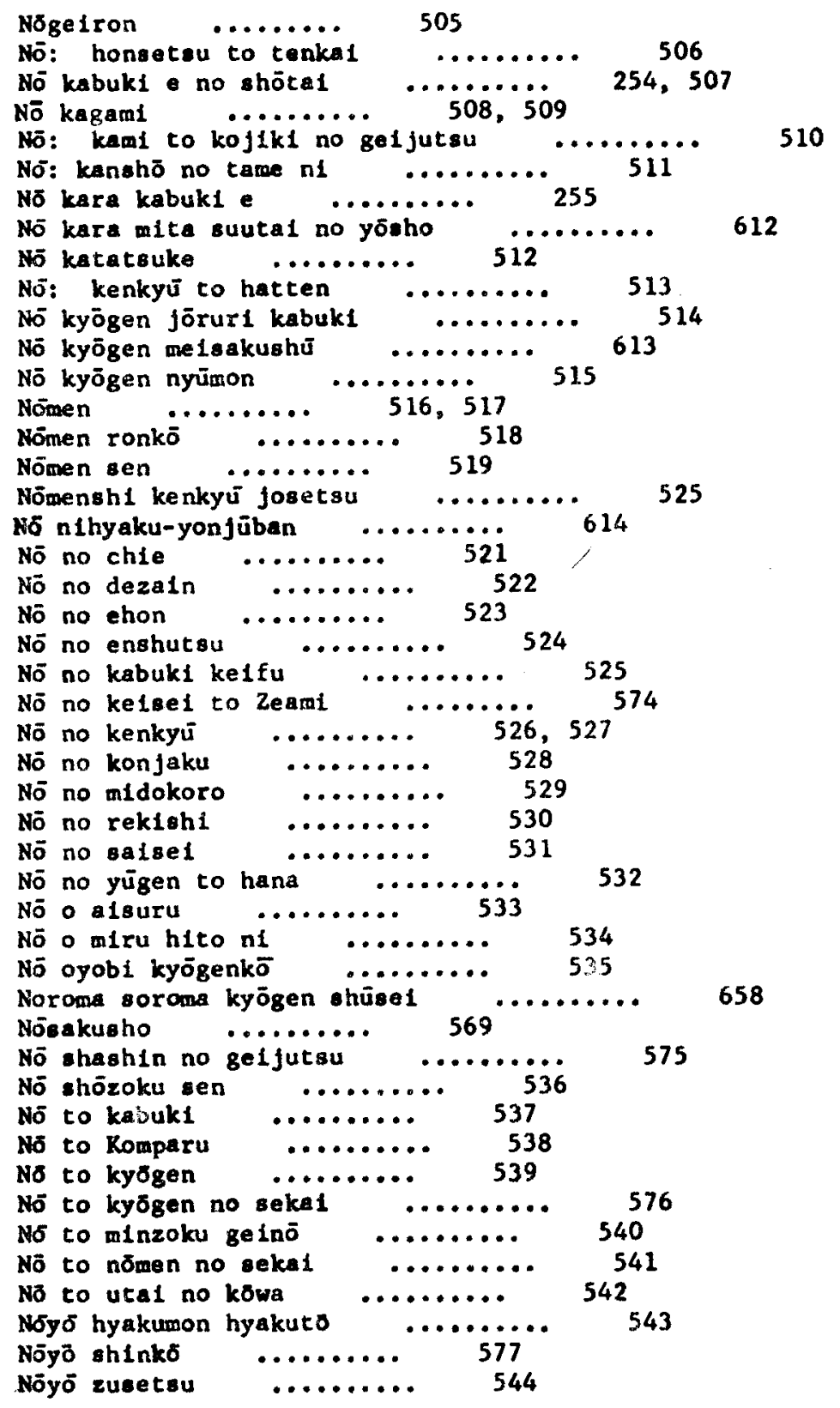



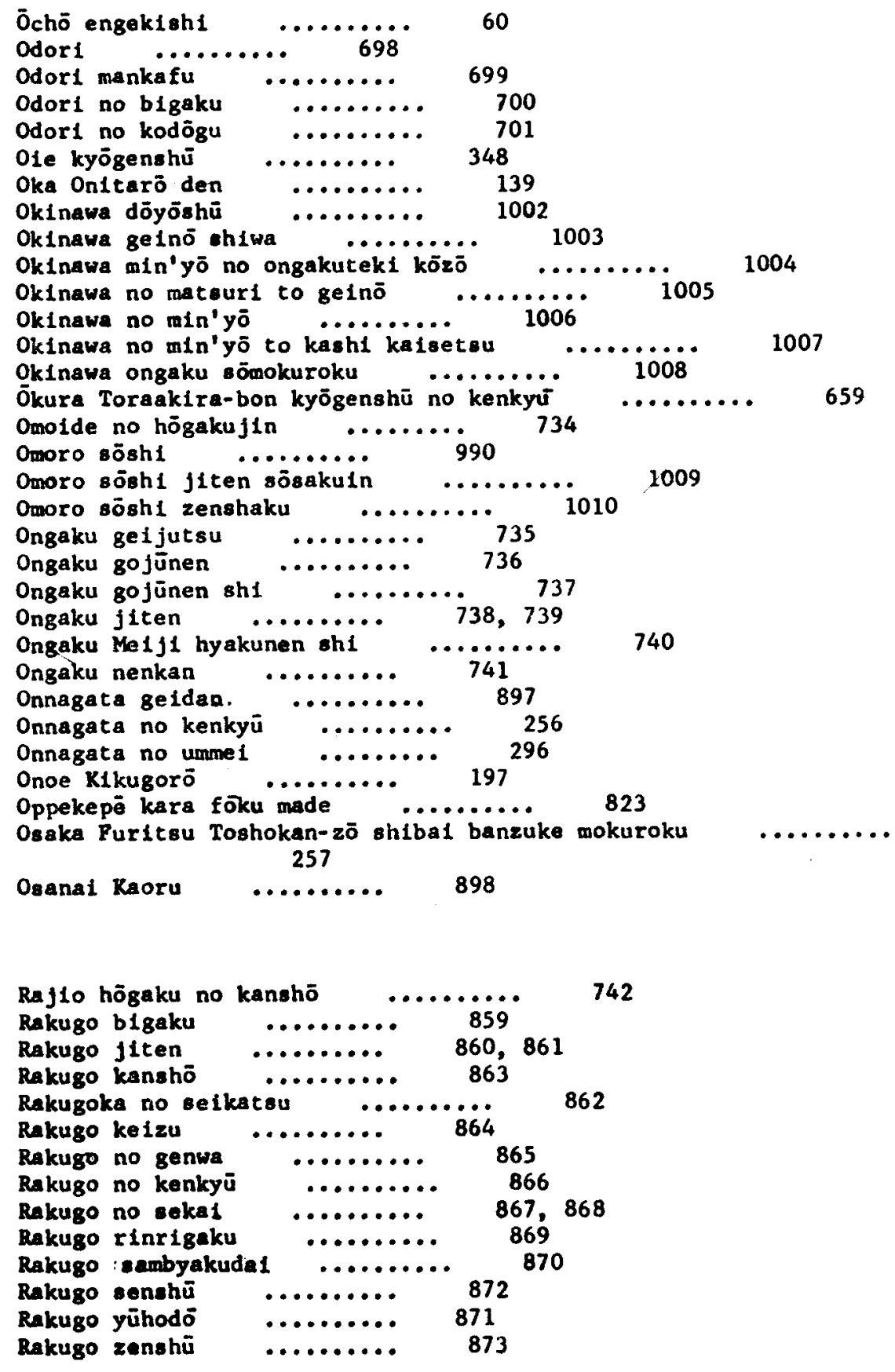


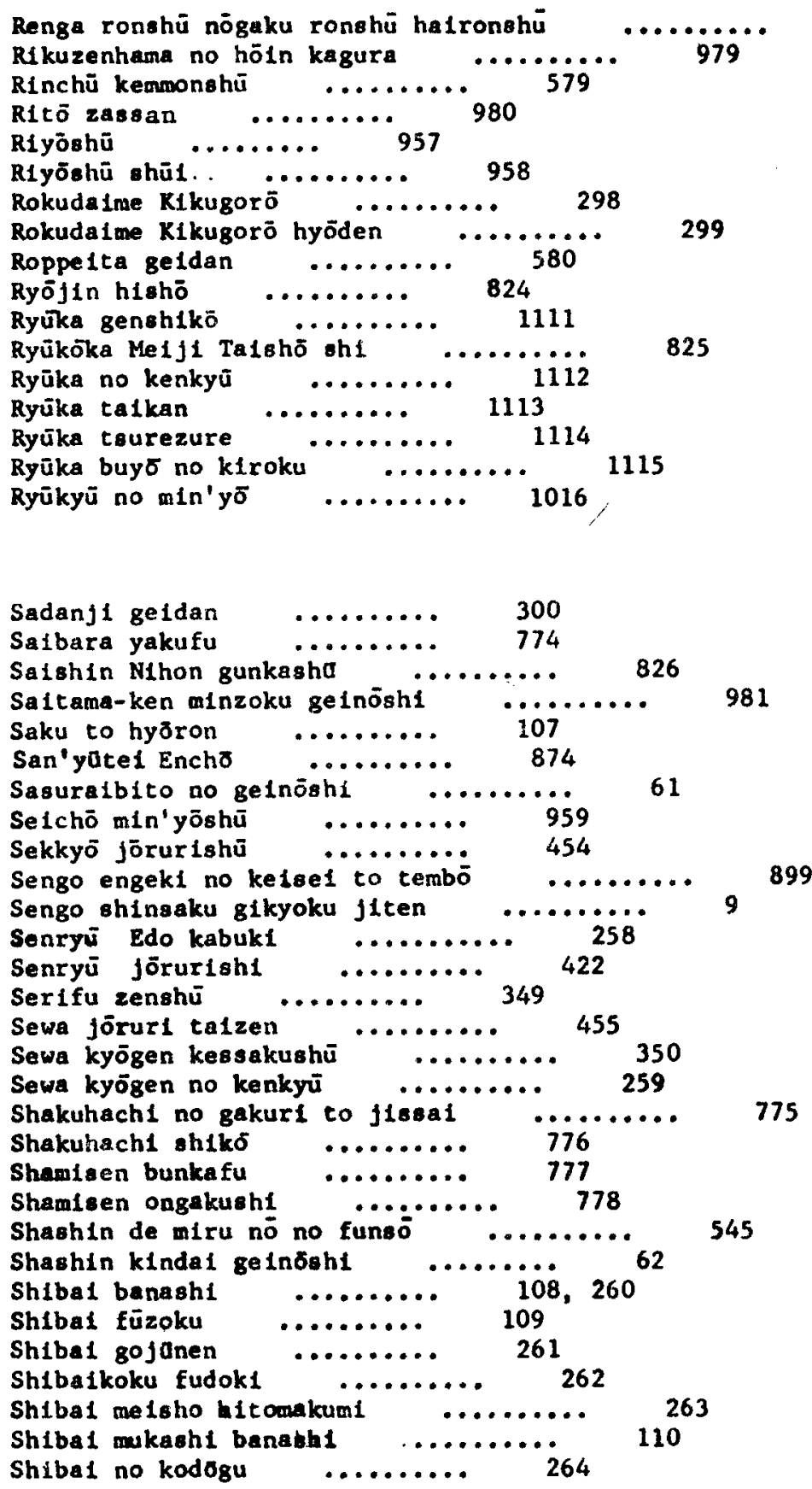




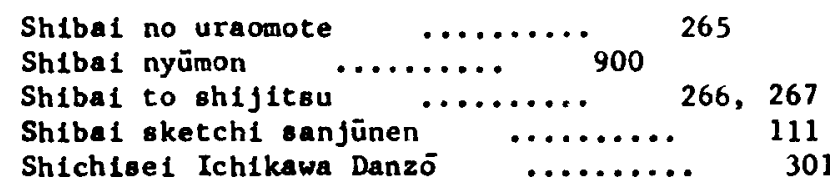

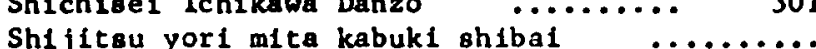

Shimaguni no uta to odori $\ldots \ldots \ldots \ldots .982$

Shimamura hōgetsu $\ldots \ldots \ldots \ldots .901,902$

Shingek1 H.........

Sh1ngek1 hyöbenki $\quad \ldots \ldots \ldots \ldots .99$

Shingeki nendaiki $\ldots \ldots \ldots \ldots .999$

Shingeki no tanjō $\ldots \ldots \ldots \ldots .906$

Shingekl tanoshi kanashi $\ldots . . \ldots . .907$

Shingek1 to watakushi $\ldots \ldots \ldots \ldots . .99$

Shingeki undō no relmeiki ......... 909

Shin kabuki no sujimichi $\ldots \ldots \ldots \ldots .269$

Sh1nkokugek1 gojünen $\quad \ldots \ldots \ldots \ldots .99$

Shin Nihon dóyoshü $\ldots \ldots \ldots \ldots . .28$

Shín nō no furusato $\quad \ldots \ldots \ldots \ldots . \quad 546$

ShInran Shōnin onkyūseki Chikuzen biwauta

Shinsaku no eng1 $\ldots \ldots \ldots \ldots$ 581

Shinsho kuruwa banashi $\ldots \ldots \ldots \ldots .875$

Shóchiku ehichijūnen shi $\ldots \ldots \ldots \ldots .63$

Shoda i Hanayagi Jusuke $\quad \ldots \ldots \ldots \ldots . \quad 702$

Shodai Sakurada Jisuke shū ......... 351

Shōgaku shōka $\quad$......... 829

Shösetsu kyakushoku kyögenshū $\ldots \ldots \ldots \ldots$

Shōsōin gakki chōsa gathō _......... 742

Shōōōin gakki no kenkyū $\quad$........

Shösōin no gakk1 $\ldots \ldots \ldots \ldots \ldots 76$

Shōwa no nō $\ldots \ldots \ldots \ldots . . . \% 547$

Shura to en $\ldots \ldots \ldots \ldots . .548$

Soga kyögen gappeishū $\quad \ldots \ldots \ldots \ldots . .343$

Sögō Nihon g1kyoku jiten $\ldots . . . . .10$

Sōkyoku gakufu Miyagi Mich1o sakkyokushū.

10

Sökyoku kashū $\quad$......... 781

Sokyoku no chishiki $\ldots \ldots \ldots \ldots .782$

sōkyoku tal1shō $\ldots \ldots \ldots \ldots \ldots 74$

Sökyokushü $\quad \ldots \ldots \ldots \ldots . \quad 783$

Sökyoku to jiuta $\ldots \ldots \ldots \ldots$.... 785

Sugao no engek1jin $\quad \ldots \ldots \ldots \ldots . \quad 112$

Taldan Nihon shingekishi $\ldots \ldots \ldots \ldots .911$

Takenoya gekihyoshū $\quad \ldots \ldots \ldots \ldots . \quad 113$

Taramatō no hachigatsu odori $1 . . . \ldots . .$.

Tauebayashi kenkyü $\quad \ldots \ldots \ldots \ldots .960$

Taue kayō to glrei no kenkyū $\quad \ldots \ldots \ldots \ldots .961$

Taue utabon shü $\quad . . \ldots \ldots \ldots .962$ 


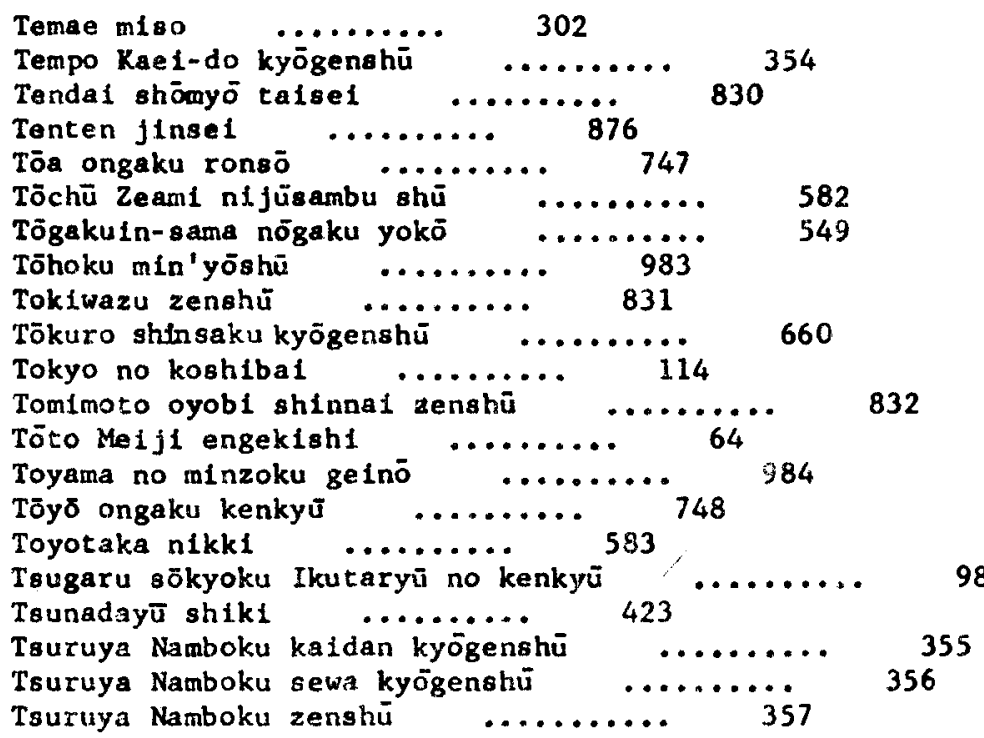

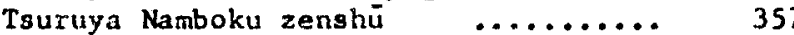

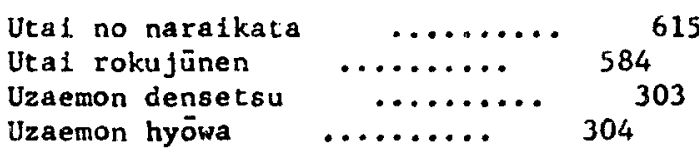

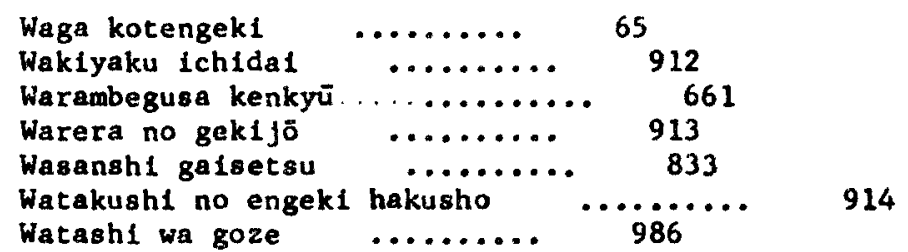

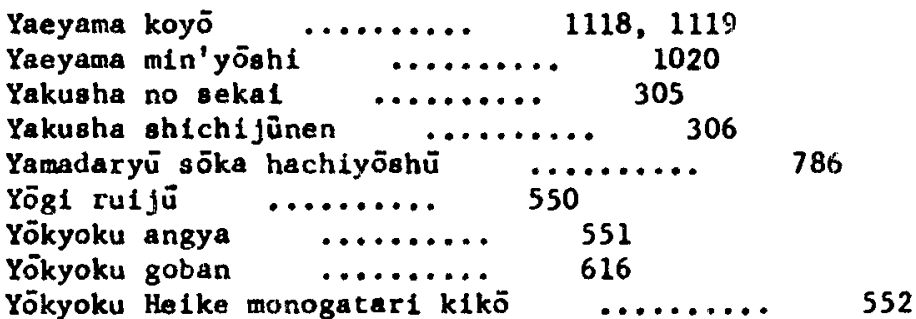




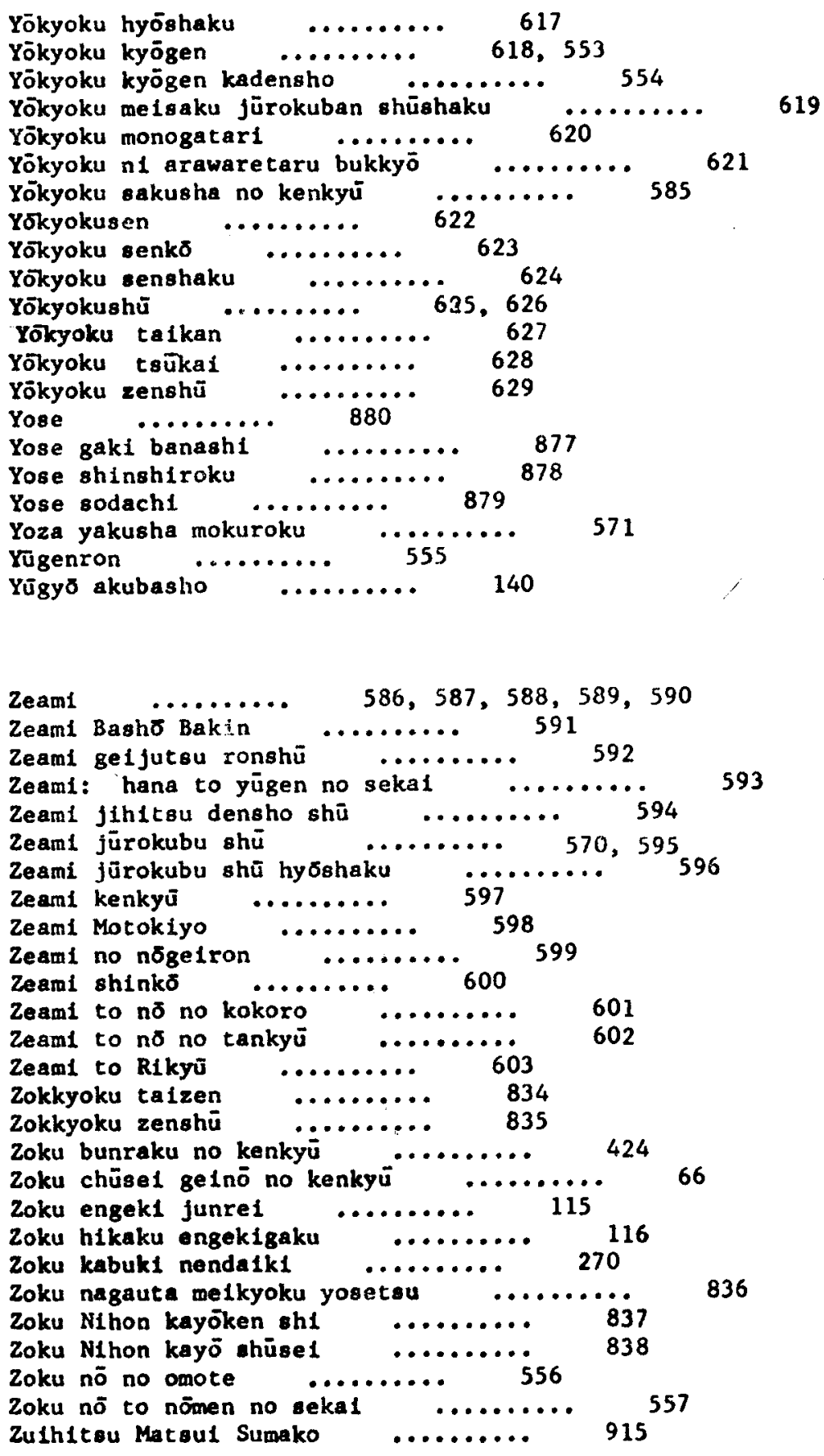




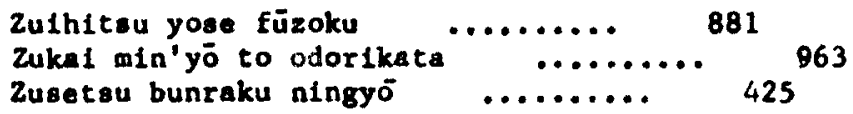

